\title{
Nanotoxicology - an in vitro approach
}

Citation for published version (APA):

Park van der Zee, M. (2012). Nanotoxicology - an in vitro approach. [Doctoral Thesis, Maastricht University]. Maastricht University. https://doi.org/10.26481/dis.20120706mp

Document status and date:

Published: 01/01/2012

DOI:

10.26481/dis.20120706mp

Document Version:

Publisher's PDF, also known as Version of record

\section{Please check the document version of this publication:}

- A submitted manuscript is the version of the article upon submission and before peer-review. There can be important differences between the submitted version and the official published version of record.

People interested in the research are advised to contact the author for the final version of the publication, or visit the DOI to the publisher's website.

- The final author version and the galley proof are versions of the publication after peer review.

- The final published version features the final layout of the paper including the volume, issue and page numbers.

Link to publication

\footnotetext{
General rights rights.

- You may freely distribute the URL identifying the publication in the public portal. please follow below link for the End User Agreement:

www.umlib.nl/taverne-license

Take down policy

If you believe that this document breaches copyright please contact us at:

repository@maastrichtuniversity.nl

providing details and we will investigate your claim.
}

Copyright and moral rights for the publications made accessible in the public portal are retained by the authors and/or other copyright owners and it is a condition of accessing publications that users recognise and abide by the legal requirements associated with these

- Users may download and print one copy of any publication from the public portal for the purpose of private study or research.

- You may not further distribute the material or use it for any profit-making activity or commercial gain

If the publication is distributed under the terms of Article $25 \mathrm{fa}$ of the Dutch Copyright Act, indicated by the "Taverne" license above, 
Nanotoxicology - an in vitro approach

Margriet Park 
(C) Margriet Park, Vleuten, 2012

ISBN: 978-94-6203-064-0

Layout: -Lein | coaching \& communicatie, Utrecht

Production: CPI / Wöhrmann Print Service, Zutphen

Financial support for the printing costs of this thesis by the National Institute for Public Health and the Environment (RIVM), Bilthoven and Stichting Stimuleringsfonds Alternatieven voor Proefdieren is gratefully acknowledged 


\section{Nanotoxicology - an in vitro approach}

\section{PROEFSCHRIFT}

ter verkrijging van de graad van doctor aan de Universiteit Maastricht, op gezag van de Rector Magnificus, prof. mr. G.P.M.F. Mols volgens het besluit van het College van Decanen, in het openbaar te verdedigen op vrijdag 6 juli 2012 om 12:00 uur

door

Margriet van der Zee Park

Geboren te Leeuwarden op 19 februari 1976 
Promotor:

Prof. dr. H. van Loveren

Copromotor:

Dr. W.H. de Jong (RIVM)

Beoordelingscommissie:

Prof. dr. L.H. Koole (voorzitter)

Dr. ir. D. van Aken (nVWA)

Dr. G.R.M.M. Haenen

Prof. dr. P. Hoet (Katholieke Universiteit Leuven)

Prof. dr. J.C.S. Kleinjans

Prof. dr. ir. I.M.C.M. Rietjens (Wageningen University)

This research was financially supported by the National Institute for Public Health and the Environment (RIVM), by the Dutch Ministry of Health, Welfare and Sport (VWS) and by the EU FP6 project Nanolnteract (NMP4-CT-2006-033231). 


\section{CONTENTS}

ABBREVIATIONS

CHAPTER 1

General introduction

CHAPTER 2

The status of in vitro toxicity studies in risk assessment of engineered nanomaterials

CHAPTER 3

In vitro developmental toxicity test detects inhibition of stem cell differentiation by silica nanoparticles

CHAPTER 4

Genotoxicity evaluation of amorphous silica nanoparticles of different sizes using the micronucleus and the plasmid lacZ gene mutation assay

\section{CHAPTER 5}

In vitro evaluation of cytotoxic and inflammatory properties of silica nanoparticles of different sizes in murine RAW 264.7 macrophages

\section{CHAPTER 6}

The effect of particle size on the cytotoxicity, inflammation, developmental toxicity and genotoxicity of silver nanoparticles

\section{CHAPTER 7}

A practical way forward to determine appropriate dose metrics for engineered nanomaterials

\section{CHAPTER 8}

Summarizing discussion and future perspectives

NEDERLANDSE SAMENVATTING

LIST OF PUBLICATIONS 



\section{ABBREVIATIONS}

3T3

3T3-L1

A549

AD

ADME

$\mathrm{Ag}$

Al

$\mathrm{Al}_{2} \mathrm{O}_{3}$

$\mathrm{AlSiO}_{2}$

AM

ATCC

$\mathrm{Au}$

BALF

BEAS-2B

BLM

BRL3A

BSA

$\mathrm{C}_{60}$

$\mathrm{Ca}_{3}\left(\mathrm{PO}_{4}\right)_{2}$

$\mathrm{CB}$

CBPI

CCD-996sk

$\mathrm{CdO}$

$\mathrm{CeO}_{2}$

$\mathrm{Cl}$

CNT

Co

$\mathrm{Cr}$

CS

$\mathrm{Cu}$

$\mathrm{CuO}$

DMEM

DMPO

DMSO

DPPC

DTNB

DTT

EAHY926
Rodent 3T3 Fibroblast

Mouse Embryonic Fibroblast

Human Lung Epithelial Cell

Distilled Water

Absorption, Distribution, Metabolism, and Excretion

Silver

Aluminum

Aluminum Oxide

Aluminum Silica

Rat Primary Alveolar Macrophage

American Type Culture Collection

Gold

Bronchoalveolar Lavage Fluid

Human Bronchus Epithelial Cell

Bleomycin

Rat Liver Cell

Bovine Serum Albumin

Fullerene

Tricalcium Phosphate

Carbon Black

Cytokinesis Block Proliferation Index

Human Skin Fibroblast

Cadmium Oxide

Ceria

Carbonyl Iron

Carbon Nanotube

Cobalt

Chromium

Crystalline Silica

Copper

Copper Oxide

Dulbecco's Modified Eagle Medium

5,5-dimethyl-1-pyrolline $\mathrm{N}$-oxide

Dimethyl Sulfoxide

Dipalmitoyl Phosphatidyl Choline

5,5'-dithiobis-(2-) nitrobenzoic acid

Dithiothreitol

Human Endothelium Cell 


\begin{tabular}{|c|c|}
\hline$E C_{x}$ & $\mathrm{x} \%$ Effective Concentration \\
\hline ELISA & Enzyme Linked Immunosorbent Assay \\
\hline ENM & Engineered Nanomaterial \\
\hline EPA & Environmental Protection Agency \\
\hline ESR & Electron Spin Resonance \\
\hline EST & Embryonic Stem Cell Test \\
\hline EU & European Commission \\
\hline FBS & Fetal Bovine Serum \\
\hline FCS & Fetal Calf Serum \\
\hline $\mathrm{Fe}$ & Iron \\
\hline $\mathrm{Fe}_{2} \mathrm{O}_{3}$ & Iron Oxide \\
\hline $\mathrm{Fe}_{3} \mathrm{O}_{4}$ & Iron Oxide \\
\hline G-CSF & Granulocyte Colony-Stimulating Factor \\
\hline Gl-tract & Gastro-Intestinal Tract \\
\hline GSH & Reduced Glutathion \\
\hline $\mathrm{H}_{2}$ DCF-DA & 2,7-dichlorofluoroscein diacetate \\
\hline HARN & High Aspect Ratio Nanoparticle \\
\hline HEK & Human Epidermal Keratinocyte \\
\hline HeLa & Human Cervical Cancer cell \\
\hline hMSC & Human Mesenchymal Stem Cell \\
\hline HMY & Human B cell \\
\hline HPRT & hypoxanthine-guanine phosphoribosyl transferase \\
\hline HT-29 & Human Colon Epithelial Cell \\
\hline ICCVAM & Interagency Coordinating Committee on the Validation of Alternative Methods \\
\hline ICP-MS & Inductively Coupled Plasma Quadrapole Mass Spectrometer \\
\hline ICRP & International Commission on Radiological Protection \\
\hline IFN $\gamma$ & Interferon $\gamma$ \\
\hline IL-1 $\alpha$ & Interleukin $1 \alpha$ \\
\hline IL-1 $\beta$ & Interleukin $1 \beta$ \\
\hline IL-6 & Interleukin 6 \\
\hline IL-8 & Interleukin 8 \\
\hline IL-10 & Interleukin 10 \\
\hline IV & Intravenous \\
\hline $\mathrm{J} 774$ & Mouse Monocyte-Macrophage \\
\hline Jurkat & Human T cell \\
\hline KG1a & CD34+ Hematopoetic Stem Cell \\
\hline L2 & Rat Lung Epithelial Cell \\
\hline L929 & Mouse Embryonic Fibroblast \\
\hline LARN & Low Aspect Ratio Nanoparticle \\
\hline LDH & Lactate Dehydrogenase \\
\hline
\end{tabular}


LPS

LTLS

MCF-7

MDA

MES

MEF

MHS

MIP-1 $\alpha$

MIP-1 $\beta$

MIP-2

mLIF

MKN-28

$\mathrm{MN}$

$\mathrm{MNU}$

$\mathrm{MnO}_{2}$

$\mathrm{MoO}_{3}$

MRC-5

MSN

MSTO

MTS

MTT

MWCNT

NEAA

$\mathrm{Ni}$

NICNAS

$\mathrm{NIOSH}$

NP

$\mathrm{O}_{2}{ }^{\bullet-}$

OECD

$\mathrm{OH}^{\bullet}$

PBL

PBS

PC3

PDI

PEG

$p, p^{\prime}-D D T$

PMA

PMEF

QD
Lipopolysaccharide

Low Toxicity Low Solubility

Human Breast Carcinoma Cell

Malondialdehyde

Mouse Embryonic Stem Cell

Mouse Embryonic Fibroblast

Rat Alveolar Macrophages

Macrophage Inhibitory Protein-1 $\alpha$

Macrophage Inhibitory Protein-1 $\beta$

Macrophage Inhibitory Protein-2

murine Leukemia Inhibiting Factor

Human Gastric Epithelial Cell

Micronuclei

$\mathrm{N}$-nitroso-N-methylurea

Manganese Oxide

Molybdenum

Human Lung Fibroblast

Mesoporous Silica Nanoparticles

Human Mesothelioma Cell

3-(4,5-dimethylthiazol-2-yl)-5-(3-carboxymethoxyphenyl)-2-(4-sulfophenyl)-2Htetrazolium.

3-(4,5-Dimethylthiazol-2-yl)-2,5-diphenyltetrazolium bromide

Multi-Walled Carbon Nanotube

Non-Essential Amino Acids

Nickel

National Industrial Chemicals Notification and Assessment Scheme

National Institute for Occupational Safety and Health

Nanoparticle

Oxygen Radical

Organization for Economic and Commercial Development

Hydroxyl Radical

Human Peripheral Blood Leukocyte

Phosphate Buffered Saline

Human Prostatic Cell

Polydispersity Index

Polyethylene Glycol

Dichlorodiphenyltrichloroethane

Phorbol Myristate Acetate

Primary Mouse Embryo Fibroblast

Quantum Dots 


\begin{tabular}{|c|c|}
\hline RAW 264.7 & Mouse Peritoneal Macrophage \\
\hline RES & Reticuloendothelial System \\
\hline RLE & Rat Lung Epithelial Cell \\
\hline ROS & Reactive Oxygen Species \\
\hline \multirow[t]{2}{*}{ SCENIHR } & Scientific Committee on Emerging and Newly Identified \\
\hline & Health Risks \\
\hline Si & Silicon \\
\hline $\mathrm{SiC}$ & Silicon Carbide \\
\hline $\mathrm{Si}_{3} \mathrm{~N}_{4}$ & Silicon Nitride \\
\hline $\mathrm{SiO}_{2}$ & Silica \\
\hline SOD & Superoxide Dismutase \\
\hline SWCNT & Single-walled Carbon Nanotube \\
\hline TEM & Transmission Electron Microscopy \\
\hline $\mathrm{TiO}_{2}$ & Titanium Dioxide \\
\hline TNF $\alpha$ & Tumor Necrosis Factor $\alpha$ \\
\hline U937 & Human Myeloid-Monocytic cell \\
\hline US-FDA & United States Food and Drug Administration \\
\hline V79 & Chinese Hamster Lung Fibroblast \\
\hline W & Tungsten \\
\hline WHO & World Health Organization \\
\hline WIL2-NS & Human Lymphoblastoid Cell \\
\hline WS1 & Human Skin Fibroblast \\
\hline WST & Water Soluble Tetrazolium salts \\
\hline XTT & Sodium 3'-1-(phenylaminocarbonyl)- 3,4-tetrazolium \\
\hline $\mathrm{Zn}$ & Zinc \\
\hline $\mathrm{ZnO}$ & Zinc Oxide \\
\hline $\mathrm{ZrO}_{2}$ & Zirconia \\
\hline
\end{tabular}






\section{CHAPTER 1}

GENERAL INTRODUCTION

Margriet V.D.Z. Park ${ }^{1,2}$

Renato Colognato ${ }^{3}$

Peter Wick ${ }^{4}$

Wim H. de Jong ${ }^{2}$

Adapted from the chapter "Interactions with the human body", published in "Adverse Effects of Engineered Nanomaterials: Exposure, Toxicology and Impact on Human Health", 2012, edited by Bengt Fadeel, Antonio Pietroiusti and Anna Shvedova.

${ }^{1}$ Maastricht University, Department of Toxicogenomics, P.O. Box 616, 6200 MD Maastricht
The Netherlands
${ }^{2}$ National Institute for Public Health and the Environment, Laboratory for Health Protection
Research, P.O. Box 1, 3720 BA, Bilthoven, the Netherlands ${ }^{3}$ Clinical Pharmacology Unit, "L. Sacco" University Hospital, Via G.B. Grassi 74, 20157 Milano, Italy ${ }^{4}$ Empa, Swiss Federal Laboratories for Materials Science and Technology, Laboratory for MaterialsBiology Interactions, Lerchenfeldstrasse 5, 9014 St. Gallen, Switzerland 



\subsection{THE NANOTECHNOLOGY ERA}

On December 29th 1959, professor Richard Feynman gave a talk at the annual meeting of the American Physical Society at the California Institute of Technology, entitled "There's Plenty of Room at the Bottom", in which he outlined how much there is to discover yet in the science of manipulating and controlling materials on a small scale (Feynman 1960). More than 50 years have passed since that 29th December and Professor Feynman's socalled "Plenty of Room", has now been partially discovered. What Professor Feynman was calling the "Bottom" can now be defined as Nanotechnology: the technology of manipulating and controlling $10^{-9} \mathrm{~m}$ materials, or engineered nanomaterials (ENMs).

With the rise of nanotechnology, there was a dramatic increase in pharmaceutical discoveries, including new methods for delayed and controlled release of drugs. One of the first scientists integrating ENMs into pharmacology was Professor Peter Paul Speiser at the ETH (Swiss Federal Institute of Technology) in Zürich, Switzerland. His research group investigated polyacrylic beads - microcapsules for oral administration of different drug formulations (Speiser and Khanna 1970). In parallel, the Department of Radiological Science at the Johns Hopkins Medical Institutions in Baltimore, US developed albumin particles of sizes ranging from 300 to $1000 \mathrm{~nm}$ which were labelled with $99 \mathrm{mTc}$ and investigated them for drug delivery purposes using the cytostatic mercaptopurine (Kramer 1974; Scheffel et al. 1973). Some years later in Japan, building upon this work, Sugibayashi et al. (1979) bound 5-fluorouracil to albumin particles. After intravenous injection into Ehrlich Ascites Carcinoma-bearing mice, he found a $20 \%$ increase in life span. These experiments sparked the interest in the development of particles for biomedical applications.

Due to their specific design, ENMs may possess physicochemical properties that distinguish them from other well known man induced (welding fume, diesel exhaust) and/ or environmental particulates, for example due to their controlled size, mass, chemical composition, active surface or charge. Nowadays, ENMs or the use of nanotechnology can be found in a wide variety of products such as electronics, automotives, health and fitness, food and beverages, goods for children and many other product categories. A total of 1317 products are already listed in an inventory of nanotechnology-based consumer products currently on the market, and show a steady, fivefold increase since March 2006 (Woodrow Wilson International Center for Scholars 2010). Considering the vast increase in nanotechnology-based products available to consumers, it is selfevident that the interaction of ENMs with biological systems should be investigated, using an interdisciplinary approach combining expertise from biology, medicine, physics, engineering and chemistry.

A lot of uncertainty exists on the potential adverse effects of ENMs, due to information that is still incomplete or missing altogether. Many institutional organizations such as the Environmental Protection Agency (EPA), the World Health Organization (WHO), the National Institute for Occupational Safety and Health (NIOSH), the European Commission 
(EU), and the Organization for Economic and Commercial Development (OECD) have addressed the need of dedicated research in order to ensure citizen protection from adverse environmental and health risks potentially caused by ENMs. For example, in its Communication 'Towards a European Strategy for Nanotechnology', the EU calls for research on appropriate methodological assays for assessing ENM toxicity (EC 2004). The $\mathrm{NIOSH}$, in collaboration with the Centre for Disease Control, recommends that specific precautions should be taken to protect workers who might be exposed to any level of ENMs or ENM-containing materials (NIOSH 2009). Meanwhile, documents are drafted by the International Organization for Standardization (ISO) for the safe and responsible production and use of ENMs (ISO 2011).

\subsection{DEFINITION AND NOMENCLATURE}

In most documents and (working) definitions, the scale describing the size of ENMs is defined as the size range between (approximately) $1 \mathrm{~nm}$ and $100 \mathrm{~nm}$ (Health Canada 2010; ISO 2010; NICNAS 2010; OECD 2008; SCENIHR 2010). Although they did not provide a regulatory definition, the FDA has also recently published a draft guidance document in which the size of approximately $1 \mathrm{~nm}$ to $100 \mathrm{~nm}$ is referred to as a first reference point to consider whether an FDA-regulated product contains nanomaterials, or otherwise involves application of nanotechnology (US-FDA 2011). In the various documents (standards and technical reports) of the ISO the word ENM covers all materials and constructs at the nanoscale (ISO 2010). In addition to ISO/TS 80004-1:2010 there will be a whole series of documents on the vocabulary to be used for the description of specific ENMs. Individual primary structures are designated ENM that can have one, two or three dimensions in the nanoscale. Agglomerates and aggregates of single primary nanomaterials are considered to be nanostructured materials and are included in the definition of ENMs. It will be obvious that when a material is specifically designed to have a size below $100 \mathrm{~nm}$ that this is an ENM. However, although the scientific community agrees on the use of the term ENMs, it becomes less clear when the definition of an ENM is discussed from a regulatory point of view. So far, regulatory definitions of ENMs are mainly limited to descriptions in governmental statements or working definitions (Health Canada 2010; NICNAS 2010; OECD 2008; SCENIHR 2010) and in one official regulation; the EU Cosmetics Directive (EC 2009). An ENM can generally be described by its nominal, primary particle size. However, any ENM is heterogeneous, i.e. not all particles in an ENM have the same size, but rather consist of particles with a specific size distribution. In case only part of the material's size distribution is below the $100 \mathrm{~nm}$ threshold, the question arises at what point one should consider a material to be an ENM. In addition, there is debate on whether the size distribution should be expressed as part of the mass or as a number size distribution. The use of number size distributions clearly indicates how many of the particles are below $100 \mathrm{~nm}$ and thus may pose a size related risk. 
Since ENMs may be particularly attractive to use because they obtain specific characteristics with diminishing size, some proposals for regulation also include a change in physicochemical properties in the definition of ENM (Health Canada 2010; NICNAS 2010; OECD 2008). For some specific types of ENMs, such as inorganic metal and metal oxides, a threshold of approximately 20-30 nm has been distinguished for a change in physicochemical properties (Auffan et al. 2009). However, for other materials this threshold was much higher, even 200-300 nm, or absent altogether (SCENIHR 2010). This indicates that there is no universal size for all ENMs at which nanospecific properties are beginning to emerge.

\subsection{PHYSICAL AND CHEMICAL PROPERTIES}

The same physical and chemical properties that confer to them great potential for industrial and biomedical applications, such as size, shape, surface chemistry and solubility (Figure 1.1) are reason for ENMs to be in the spot light of regulators and scientists in the area of public and environmental health (Nel et al. 2006)

One of the main characteristics distinguishing ENMs from bulk materials is nanoparticle size, or more specifically, surface to volume ratio. ENMs possess a large surface area compared to their respective bulk materials and this is thought to make ENMs considerably more biologically reactive. For example, a $300 \mathrm{~nm}$ NP has $5 \%$ of its atoms on the surface while the remaining atoms reside inside. In comparison, a $30 \mathrm{~nm}$ NP has $50 \%$ of its atoms on the surface. The atoms at the surface, which are not bonded on one side, are more active than the atoms residing inside. An increase in surface area therefore likely leads to an increase in surface reactivity, and may result in an increase in biological (toxicological) activity.

With regard to shape, ENMs can be roughly distinguished into high- and low-aspectratio nanoparticles, HARN and LARN respectively. High-aspect ratio ENMs include nanotubes and nanowires, with various shapes, such as helices, zigzags, belts, and may vary in length. LARN morphologies include spherical, oval, cubic, prism, helical, or pillar. A shape-dependent biological response was reported by Tarantola and coworkers (2011) who demonstrated that coated spherical AuNPs with identical surface functionalization were generally more efficiently ingested and more toxic than rod-shaped particles.

Other physicochemical properties that may contribute to the behaviour and biological responses of ENMs are the stability and agglomeration state. In aerosols and in colloidal suspensions, ENMs can exist in a well-dispersed or in an agglomerated state, depending on the chemistry and electromagnetic properties of both the ENMs and their surroundings. For example, magnetic ENMs tend to cluster, forming an agglomerated state, unless their surfaces are coated with a non-magnetic "shell". Aggregation or agglomeration state could influence the deposition, toxicokinetics, and local toxicity of ENMs, due to significant variations in the aerodynamic radius and total surface area of the ENMs that tends to be reduced (Borm et al. 2006; Tsuji et al. 2006; Wick et al. 2007). 


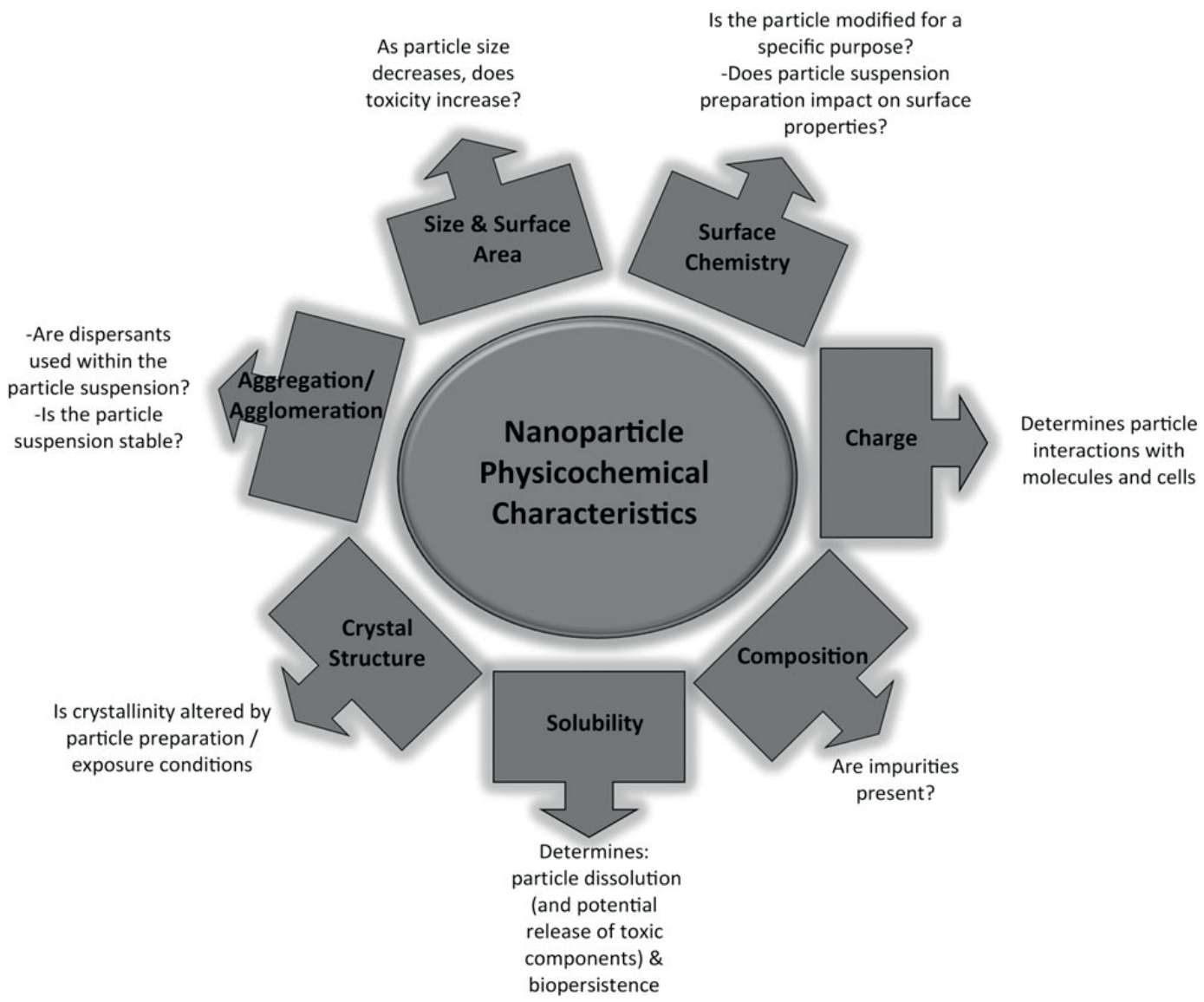

Figure 1.1 Physicochemical properties of nanomaterials that have been demonstrated to influence their toxicity (from Johnston et al. (2010), with permission from Oxford Journal).

ENMs may also vary in their surface charge, with consequences for the biological effects they induce. For example, positively and negatively charged gold (Au) NPs displayed toxicity at concentrations at least 2.5 fold lower than neutral NPs (Schaeublin et al. 2011). Factors such as particle size, shape and surface properties have also been shown to play a role in the toxicity of silver (Ag) NPs (Carlson et al. 2008; El Badawy et al. 2011; Pal et al. 2007).

\subsection{INTERACTIONS WITH BIOLOGICAL SYSTEMS}

When ENMs come into contact with biological systems, a nano-bio-interface is generated. This interface comprises the dynamic physicochemical interactions, kinetics and thermodynamic exchanges between the surfaces of ENMs and biological components, such as proteins 
and phospholipids (Lynch et al. 2009; Nel et al. 2009). The solid-liquid interface is a key issue in ENMs-cell interactions, but an understanding of this interface is often lacking. It is the amount and presentation of the biomolecules on the surface rather than the particles themselves that is suggested to be the cause of numerous biological responses (Lynch et al. 2009; Nel et al. 2009). In other words, it is the outer layer of biomolecules that is seen by the cells, and leads to the interaction of the particles with the cell.

The most abundant biomolecules, which interact with ENMs in biological environments, are proteins (Cedervall et al. 2007; Lynch et al. 2009). There are some studies that have characterized and identified the adsorbed proteins - the corona - on different ENMs. A major outcome is that the NPs size and surface properties determine the protein composition of the corona and by that influence the biological activity and molecular targeting of ENMs (Dutta et al. 2007; Lundqvist et al. 2008). Interaction with ENMs may also have an effect on protein assembly and fibrillation (Cabaleiro-Lago et al. 2010). Protein binding to nanoparticles is not a static process, but rather a dynamic exchange of the adsorbed proteins with the biological environment of the ENMs. Modelling of such binding processes may offer a more detailed understanding of the solid-liquid interface (Bertolazzi et al. 2010; Dell'Orco et al. 2010).

The possible portals where ENMs may enter the human body are the lungs via inhalation, the gastro-intestinal tract via digestion, the skin, and the blood vessels via intravenous injection (Krug and Wick 2011). However, the most critical (human) exposure route for ENMs is thought to be the pulmonary system. Upon deposition, ENMs come in initial contact with the pulmonary surfactant, which is located at the air-liquid interface. Surfactant contains 85 - 90\% phospholipids and 10\% surfactant proteins (Gasser et al. 2010). In a recent study with functionalized multi-walled carbon nanotubes (MWCNT) it was shown that pulmonary phospholipid coating has the potential to alter the plasma protein coating of the tubes. This change in the pattern of adsorbed proteins is hypothesized to significantly influence the interaction and subsequent effects of the MWCNT on biological systems (Gasser et al. 2010; Schleh et al. 2011). Understanding the time evolution of nanobio interface in a given biological environment, and in particular the understanding of the dynamic exchanges of biomolecules may help to predict the particle's fate, biological activity or even its life time in an organism.

\subsection{TRANSPORT INTO THE CELL}

Phagocytosis is recognized as an important process in cell entry of particles (Conner and Schmid 2003). However, other mechanisms too are responsible for the uptake of metals, metal oxides, or other particulate nanosized systems by the cell (Limbach et al. 2007), and for the different biological reactions that may follow. Although particles with diameter below $100 \mathrm{~nm}$ are capable of getting into the cell by almost any vesicle transport pathway (Geiser et al. 2005; Limbach et al. 2005; Oberdorster et al. 2005a), further options are 
to be considered, for example transport of ENMs into cells due to receptor binding (Dobrovolskaia and McNeil 2007; Kanno et al. 2007) or even "diffusion" through the plasma membranes, which is referred to as an adhesive interaction (Geiser et al. 2005; Rothen-Rutishauser et al. 2006). It was demonstrated that ENMs could advance into the cell interior of erythrocytes, whereas larger particle were unsuccessful (Rothen-Rutishauser et al. 2006). This is surprising, as the erythrocytes lack the conventional uptake mechanisms. Regardless of how the ENMs gain entry into a cell, the process of infiltration is indeed reminiscent of a Trojan horse invasion because a veritable material package is delivered by introduction of only one particle into the cell (Figure 1.2) (Krug and Wick 2011).

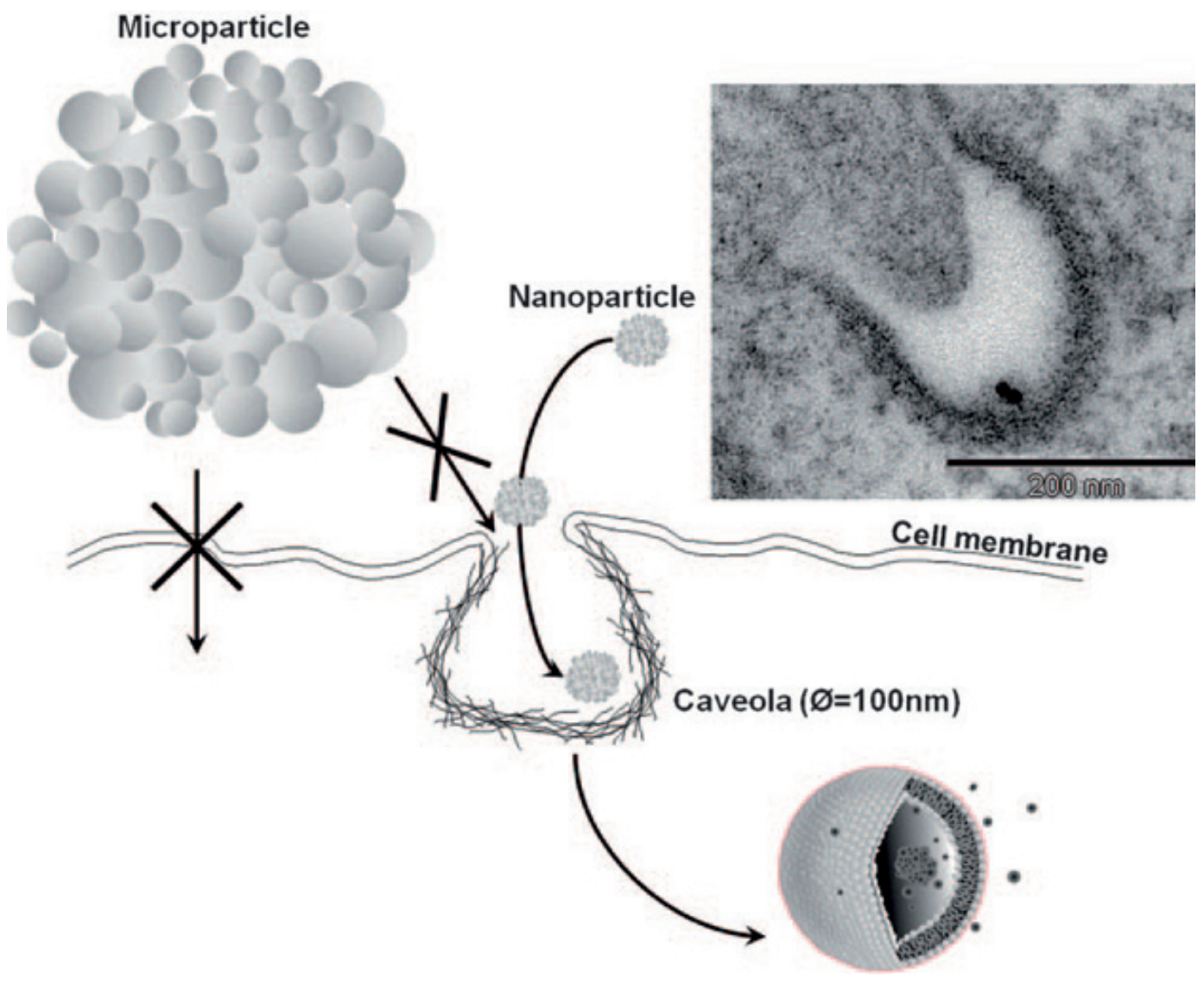

Figure 1.2: Comparison of the possible uptake of nanoparticles and microparticles via vesicular pathways (caveolae). Only small particles with a diameter of less than $100 \mathrm{~nm}$ fit into vesicular structures such as caveolae, by which they will be transported into the plasma. Within the cells, these vesicles may fuse to build up a lysosome with an acidic interior, facilitating the dissolution of materials such as $\mathrm{ZnO}$. The ions can move relatively freely inside the cells. The transmission electron microscopy (TEM) image shows a situation where two nanoparticles $(22 \mathrm{~nm}$ ) are located within the caveolae of a lung epithelial cell (A549) in culture. (From Krug and Wick (2011) with permission from Angewandte Chemie Int Ed). 
The biological response of cells to ENMs is influenced by the different uptake processes. Free transport through the membrane allows particles to achieve direct contact with the plasma proteins and with other molecules of the cell. Dependent on the material properties of the ENMs, this may have fatal consequences for the cells, and is therefore considered to be more critical than vesicular uptake, where particles are sheathed by membranes. Once taken up, soluble ENMs such as ZnO may dissolute and generate a hot spot of free zinc at a much higher level than the surrounding average concentration would be (Xia et al. 2011). Particles that do not dissolve but remain catalytically 'active' have the potential to stress the cell or tissue as well (Limbach et al. 2007). Even inert particles may affect cell responses by introducing xenobiotics adsorbed on the particle surface, which detach after cellular uptake. This piggy-back transportation is well known for combustion derived particles where different types of polycyclic aromatic hydocarbons (potential mutagenic compounds) were identified on these particle surfaces (Kocbach et al. 2006). The uptake of certain non-reactive materials may be particularly critical when they are nanosized: particle distribution within an organism is differently controlled than the transport of ions or the corresponding bulk material, indicating that ENMs may reach other types of cells and tissues in an organism. As indicated below, the body has a very efficient reticuloendothelial-system (RES) to remove particulate matter from the circulation.

\subsection{BIODISTRIBUTION, BIODEGRADATION AND BIOPERSISTENCE}

The biodistribution, biodegradation and biopersistence, in short, the kinetic properties of ENMs can be described by four processes: absorption, distribution, metabolism, and excretion (ADME). In general, four main routes of exposure can be distinguished i.e. oral, inhalation, dermal and systemic intravenous (IV) injection. The route of human exposure, with the exception of medical treatment, will not likely be the IV route. Nevertheless, many experimental in vivo studies have been performed using IV administration in order to avoid problems with (lack of) barrier passage in the gastro-intestinal (GI)-tract, lung or skin, and as such to simulate worst case (exposure) scenario purposes. In addition, studies using IV administration are used to evaluate the tissue distribution for ENMs that become systemically available, in order to determine which organs may be at risk for ENMs toxicity. It should be realised that the route of entry itself also may affect the tissue distribution. Especially when comparing IV with inhalation administration, the translocation through the air/blood barrier may result in alterations of the ENMs (Oberdorster 2010; SemmlerBehnke et al. 2008). IV administration results in direct contact with blood, upon which the particle surface becomes coated with numerous proteins including immunoglobulins that can enhance recognition and uptake by cells of the reticuloendothelial system (RES) (Aggarwal et al. 2009; Dobrovolskaia et al. 2009; Lacerda et al. 2010). This results in entrapment of the ENMs mainly in organs of the RES with a high content of mononuclear 
phagocytes (macrophages) such as liver and spleen (De Jong et al. 2008; Sadauskas et al. 2007). The sequestration of the particles into the liver and spleen is rapid, and can occur within minutes (Lankveld et al. 2010; Lankveld et al. 2011; Lipka et al. 2010). For more specific applications such as drug targeting, modification of the surface area by coatings or antibodies may be used. Cellular binding may be increased by the use of carbohydrates (Weissenbock et al. 2004), whereas the use of certain antibodies enables a more specific immunological targeting of the ENMs (Nobs et al. 2004; Prinzen et al. 2007). Cellular entrapment in macrophages can be avoided by surface modification of the ENMs with polyethylene glycol (PEG), which increases their circulation time in the blood by inhibiting recognition and phagocytosis by macrophages (Akiyama et al. 2009; Lankveld et al. 2011; Lipka et al. 2010; von Maltzahn et al. 2009). The use of PEG as a particle coating may also result in a change in local tissue exposure (Lankveld et al. 2011; Lipka et al. 2010).

The size of ENMs can also be a significant determinant of particle tissue distribution, as shown for spherical Au and Ag NPs, Au composite nanodevices (Balogh et al. 2007; De Jong et al. 2008; Hirn et al. 2011; Semmler-Behnke et al. 2008), polystyrene ENMs (Wick et al. 2010), and Ag nanoparticles (Lankveld et al. 2010). For example, $20 \mathrm{~nm} \mathrm{Ag} \mathrm{NPs} \mathrm{distributed} \mathrm{mainly}$ to liver, followed by kidneys and spleen, whereas 80 and $110 \mathrm{~nm}$ Ag NPs distributed mainly to spleen followed by liver and lung. In the other organs evaluated, no major differences between the sizes were observed (Figure 1.3). In addition, $20 \mathrm{~nm} \mathrm{Ag} \mathrm{NPs} \mathrm{appeared} \mathrm{to} \mathrm{be}$ excreted (or dissolved) at a faster rate compared to the larger NPs (Lankveld et al. 2010).

IV administration of quantum dots with a hydrodynamic diameter $<5.5 \mathrm{~nm}$ resulted in rapid and efficient urinary excretion and elimination of the quantum dots from the body, whereas for larger quantum dots excretion was reduced and retention in the body was increased (Choi et al. 2007).

The systemic bioavailability of ENMs after exposure via other routes is generally much lower. After exposure of the lung by either inhalation or instillation, only a small but significant fraction of the dose of ENMs was found to be absorbed into the body (Ji et al. 2007; Kreyling et al. 2002; Lipka et al. 2010; Semmler-Behnke et al. 2008; Sung et al. 2011). Such translocation may be rapid and size dependent (Kreyling et al. 2002). With prolonged inhalation exposure to $\mathrm{Au}$ ENMs, a notable increase in systemic organ distribution was observed between 5 and 15 days, indicating ENM accumulation (Yu et al. 2007). The elimination half time for both fine and ultrafine (nano)particles in rats was found to be around 65 days (Pauluhn 2009; Pauluhn 2011). Translocation of ENMs into the brain after inhalation exposure may take place via the olfactory nerve pathway, similar to what was found for nanosized polio virus particles (reviewed by Oberdorster et al. 2005b).

Oral uptake of ENMs may occur when nanosized formulations are used to increase the systemic availability of food components and drugs (Bowman and Leong 2006; Muchow et al. 2008; Powell et al. 2010). For these particular applications, the biodegradation of the 
nanoformulations is an inherent prerequisite. Although the risks of these biodegradable ENMs need to be assessed as well, there is more concern about the potential adverse effects of non-degrading ENMs that may accumulate in the body. Uptake from the GI-tract after oral administration was demonstrated for several types of ENMs, including relatively large $\left(500 \mathrm{~nm}\right.$ ) titanium dioxide $\left(\mathrm{TiO}_{2}\right)$ particles (Jani et al. 1994; Kim et al. 2008; Park et al. 2010a; Wang et al. 2007).

In vitro studies investigating penetration of intact skin by ENMs have reported contradicting results (Larese Filon et al. 2011; Ryman-Rasmussen et al. 2006; Smijs and Bouwstra 2010; Wu et al. 2009). In vivo studies reported uptake via the skin of silica $\left(\mathrm{SiO}_{2}\right)$ NPs (70 nm), quantum dots ( $35 \mathrm{~nm}$ ), and $\mathrm{TiO}_{2}$ NPs (4 nm and $60 \mathrm{~nm}$ ) (Nabeshi et al. 2011; Wu et al. 2009), although oral uptake via grooming could not be excluded in these studies. Subcutaneously injected Ag NPs were mainly found to distribute to liver, kidney, spleen, lung and brain (Tang et al. 2009). In humans, a minimal uptake of $\mathrm{Zn}$ was observed after application of a $\mathrm{ZnO}$ containing sunscreen preparation, but whether this was taken up as $\mathrm{Zn}$ ions or ZnO ENMs could not be identified (Gulson et al. 2010).

The indication of systemic availability of ENM after exposure via the Gl-tract or the skin implies that these exposure routes need to be considered when evaluating the safety of ENMs.

For most ENMs, it is doubtful that actual metabolism occurs, especially in case of solid ENMs. Yet, some ENMs such as polymeric constructs and phospholipid liposomal formulations can be specifically designed to be degradable for release of incorporated drugs (De Jong and Borm 2008; Duncan 2006; Irache et al. 2011). Potential solubility or insolubility is the key factor that determines whether a nanomaterial has the potential for bioaccumulation in cells and organs. $\mathrm{Ag}$, copper oxide $(\mathrm{CuO})$ and $\mathrm{ZnO}$ NPs are known to release ions that are considered to be responsible for part of their toxicity, indicating that degradation does occur to some extent (Dimkpa et al. 2011; Park et al. 2010b; Wijnhoven et al. 2009).

The potential biopersistence of non-degradable ENMs is considered one of the concerns in relation to possible long term chronic effects of ENMs. However, in the absence of chronic studies, there is a lack of information on the biopersistance of ENMs. There are indications that $\mathrm{Ag}$, aluminum oxyhydroxide and $\mathrm{TiO}_{2} \mathrm{NPs}$ may indeed be biopersistent, warranting further long-term studies (Fabian et al. 2008; Lankveld et al. 2010; Pauluhn 2009).

\subsection{POTENTIAL ADVERSE EFFECTS}

Due to the relatively recent introduction of nanotechnology in industry, epidemiological studies, case studies and other human data on potential adverse effects of ENMs are virtually absent. Any existing information on potential adverse effects is largely based on animal and in vitro studies with (human) cell lines, generating much information on the potential interactions of ENMs with the cell and mechanisms of action of ENMs (Figure 1.4). 

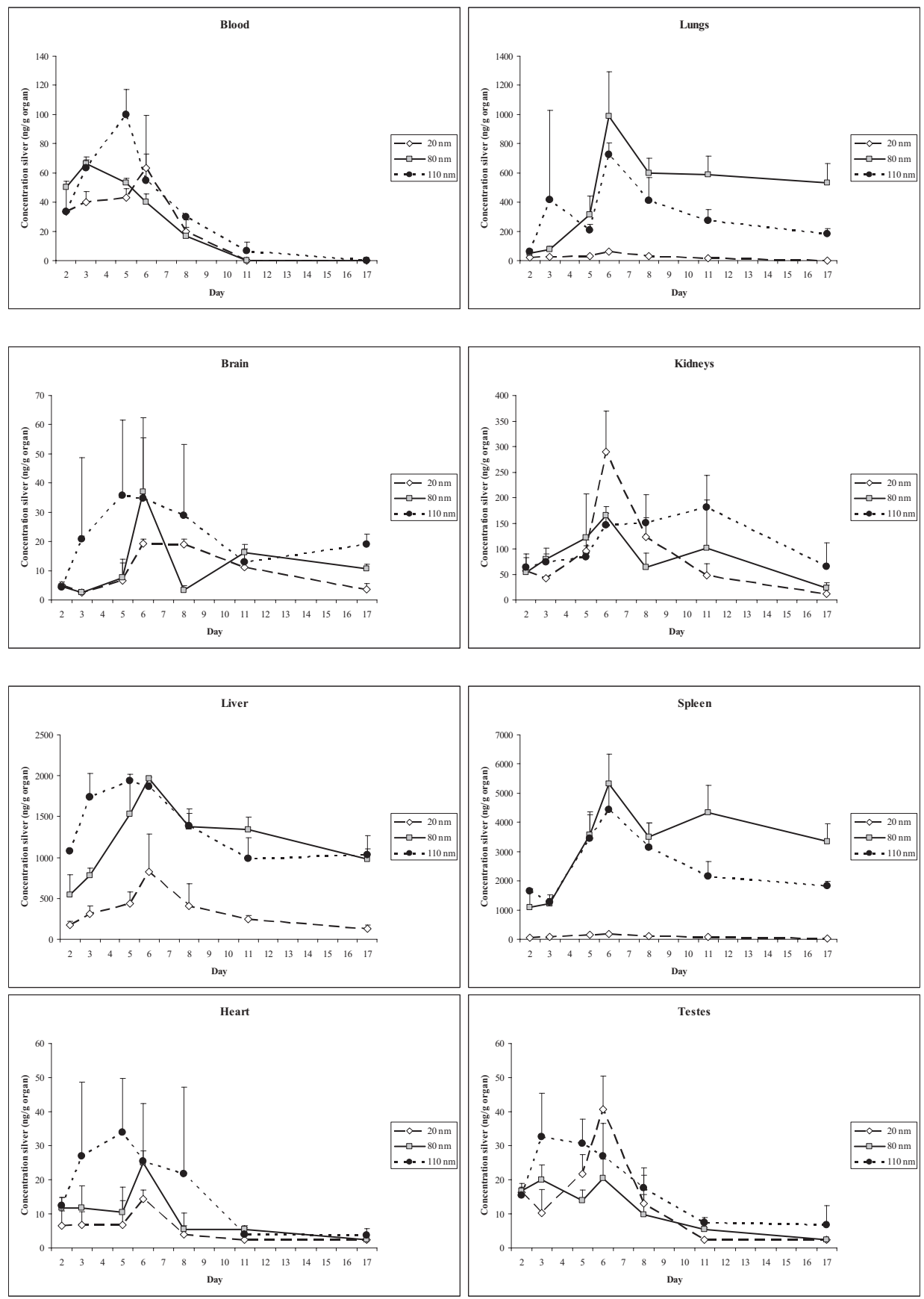

Figure 1.3 Tissue distribution and kinetics of Ag nanoparticles of $20 \mathrm{~nm}, 80 \mathrm{~nm}$ and $110 \mathrm{~nm}$. Animals received 5 consecutive IV administrations, $\mathrm{n}=3$, error bar indicates standard deviation (From Lankveld et al., (2010), with permission from Elsevier). 
Since inhalation exposure is thought to be the most relevant exposure route to ENMs, adverse effects are mainly expected to occur in the lung. A large body of literature already exists on inflammatory effects in the lung as a result of exposure to ambient particulate matter, and not coincidentally, this is also one of the most investigated and reported effects for engineered ENMs in the published literature (Ayres et al. 2008; Madl and Pinkerton 2009; Napierska et al. 2010; Oberdorster et al. 2005b). Numerous short term studies report the induction of inflammation markers in rats after instillation with and inhalation of metal (oxide) ENMs and in many in vitro models representing the human (Cho et al. 2010; Gosens et al. 2010; Hsiao and Huang 2011; Kasper et al. 2011; Sager and Castranova 2009; Sung et al. 2009). The pulmonary inflammatory properties of low solubility ENMs such as titanium dioxide $\left(\mathrm{TiO}_{2}\right)$ and carbon black have been suggested to be related to particle surface area rather than mass (Sager and Castranova 2009), although other physicochemical properties such as ENMs surface chemistry and crystallinity also play a role (Duffin et al. 2007; Warheit 2010). Local persistence in the lung of low toxic particulates resulting in chronic inflammation may be a cause for non-genotoxic induction of lung tumors in the rat as suggested for both fine and ultrafine (nano) $\mathrm{TiO}_{2}$ ( $\mathrm{NIOSH}$ 2011). In addition to eliciting inflammatory responses in the lung by themselves, ENMs have also been shown to aggravate endotoxin-elicited lung inflammation and airway hypersensitisation in mice by acting as adjuvants (de Haar et al. 2006; Inoue and Takano 2011). Conversely, immunosuppressive effects have been reported in mice after inhaling carbon nanotubes (Mitchell et al. 2009).

As discussed previously, exposure routes other than inhalation are also relevant for ENMs, for example when applied in cosmetics and in food, leading to exposure via the skin and the digestive tract, respectively. Especially the use of ENMs for biomedical applications such as intravenous diagnostic tools or drug carriers will lead to relatively high levels of systemic bioavailability, which often is even targeted at a specific organ or tissue. The ideal design of an ENM that is used for these medical purposes is aimed to be quickly removed from the body after it has completed its task, and as such, the potential risk of systemic bioavailability of these particular ENMs may not outweigh the benefits (De Jong and Borm 2008; Duncan 2006; Hahn et al. 2011; Irache et al. 2011; McNeil 2009). Nevertheless, any application that may lead to systemic bioavailability of ENMs will need to address potential systemic toxicity in their safety assessments.

An example of a toxic endpoint relevant for systemic exposure is the potential of ENMs to cause DNA damage. ENMs have been reported to induce genotoxic effects in vitro (Colognato et al. 2008; Migliore et al. 2010), but very few in vivo studies are available to evaluate these effects at relevant exposure levels (Gonzalez et al. 2008; Landsiedel et al. 2009; Singh et al. 2009). Similarly, information on the effects of ENMs on reproduction and embryonic development are very scarce and mostly limited to in vitro studies, or in vivo studies using very high doses, for which the relevance of the results to humans is difficult to interpret (Ema et al. 2010; Hougaard et al. 2011). One study in pregnant mice inhaling surface coated $\mathrm{TiO}_{2}$ at concentrations relevant to human occupational exposure limits 
resulted in lung inflammation in adult females and neurobehavioral changes in offspring (Hougaard et al. 2010).

In general, while acute effects resulting from short-term exposure to high levels of ENMs, such as the inflammatory effects or DNA damage in vitro, have been investigated to a reasonable extent, little information exists on the effects of chronic exposure to low levels of persistent ENMs. Epidemiological studies have associated exposure to ambient ultrafine particular matter with systemic effects such as cardiovascular and neurodegenerative diseases and adverse birth outcomes (Brook et al. 2010; Shah and Balkhair 2011; Simko and Mattsson 2010). The generation of oxidative stress (discussed in the next section) that is believed to play an important role in at least some of these effects has also been observed in studies with ENMs and suggest that these effects may be relevant for ENMs, which warrants further investigation (Simko and Mattsson 2010; Xia et al. 2009).

\subsection{MECHANISMS OF ADVERSE EFFECTS}

The generation of reactive oxygen species (ROS) and oxidative injury is considered to play a significant role in many of the observed biological responses to ENMs (Figure 1.4). Due to the large surface area of ENMs, relatively more reactive groups are located on the surface and as such may be available for electron transfer to oxygen, forming superoxide, a precursor of other ROS (Nel et al. 2006). ROS may also be generated as a result of ENM-cell interactions, even in the absence of reactive groups on the surface (Xia et al. 2006). During normal cellular processes such as mitochondrial respiration, low levels of ROS are also generated, but these are immediately neutralized by the cell's antioxidant machinery. However, when the generation of ROS exceeds the cell's antioxidant capacity, a state of oxidative stress is induced in the cell. ENM size, surface area and surface chemistry (i.e. reactive groups) are thought to play a role in the generation of ROS. Apart from the damaging effects to cellular proteins, lipids and DNA, an increasing level of ROS triggers the cell to respond by inducing pro-inflammatory signalling cascades, and ultimately induces programmed cell death (Nel et al. 2006).

Additionally, ENMs may induce or aggravate inflammatory and allergic responses by directly influencing immune related cell populations in the lung (Inoue and Takano 2011). After lung exposure ENMs recruit neutrophilic granulocytes to the lung and partially end up in lung macrophages (Gosens et al. 2010; Oberdorster et al. 2005b; Semmler-Behnke et al. 2008). In turn, persistent oxidative stress and inflammation in lungs and brain tissue after exposure to particulate matter are thought to be the underlying cause for lung fibrosis and neurodegenerative diseases, respectively (Brook et al. 2010; Simko and Mattsson 2010).

As discussed previously, the very same properties that make ENMs interesting to enhance target delivery of pharmaceutical drugs, antigens for vaccination or diagnostic contrast agents may also enhance transport of undesirable compounds to tissues and cell components. For example, cytotoxicity of $\mathrm{Ag}$ and $\mathrm{Cu}$ ENMs was reported to be due in part 
by shuttling their respective ions into the cell (Dimkpa et al. 2011; Park et al. 2010b; Studer et al. 2010; Wijnhoven et al. 2009).



Figure 1.4 Possible interactions of ENMs with the cell and subcellular structures. Suggested mechanisms underlying nanoparticle induced responses at the cellular level, which at sufficiently high or persistent levels can potentially lead to altered tissue function and damage.

In addition, trace amounts of $\mathrm{TiO}_{2}$ ENMs synergistically increased the genotoxic effects of dichlorodiphenyltrichloroethane ( $\left.p, p^{\prime}-D D T\right)$ in human hepatocytes, presumably by adsorption of $p, p^{\prime}$-DDT to the surface of the ENMs (Shi et al. 2010). In a similar way, ENMs may act as adjuvants for antigens, aggravating allergic responses, or they may act as antigens or haptens themselves (Zolnik et al. 2010). Conversely, the immunosuppressive effects of inhaled carbon nanotubes on $B$ cell function in mice was reported to be mediated by the production of TGF- $\beta$ by alveolar macrophages, which activated cyclooxygenase enzymes in the spleen (Mitchell et al. 2009). The changes in neurobehavioral patterns observed in offspring of mice exposed to $\mathrm{TiO}_{2}$ are another example of potential indirect toxicity of ENMs. Since the transfer of $\mathrm{TiO}_{2}$ over the placenta after inhalation was expected to be low, the effects may have been caused by release of the coatings of the ENMs or by cytokines released in the inflammatory response in the lungs of the pregnant mice (Hougaard et al. 2010). 
Effects of ENMs on the integrity of DNA can result from both direct interaction of ENMs with the DNA, the generation of ROS or as a consequence of persistent inflammation. In addition, it has been shown especially for carbon nanotubes that the presence of production residues such as metal ions (used as catalysts), structural defects and the aspect ratio are important properties relevant to (geno)toxicity. The mechanisms underlying the toxicity of fibre-like ENMs are discussed in more detail in the next paragraph.

\subsection{THE FIBRE PARADIGM}

The experience with certain HARN (fibres) such as asbestos highlighted that types of ENMs similar to asbestos may pose an additional hazard to the lung beyond that produced by conventional compact particles and gave rise to the discipline of fibre toxicology (Donaldson et al. 2010a,b). Several decades of fibre toxicology have led to an overarching fibre toxicology structure activity paradigm involving length (>20 $\mu \mathrm{m})$, diameter $(<3 \mu \mathrm{m})$ and biopersistence. Such fibres can be deposited in the lung beyond the ciliated airways but then they cannot be completely removed by the alveolar macrophages resulting in what is now designated as frustrated phagocytosis. If the fibres, due to a rigid structure, retain their fibrous shape during residence in the lung, the total fibre dose may accumulate (Donaldson 2009). Single- and multi-walled carbon nanotubes (SWCNTs and MWCNTs) are used increasingly in different materials science applications. They have been attracting major attention owing to their alleged hazards to health. These hazards have been attributed to their morphological properties based on their likeliness to asbestos. Recent studies demonstrated that aerosolized CNTs could reach the sub-pleura and induced fibrosis in mice up to 6 weeks following a single exposure of 6 hours (Ryman-Rasmussen et al. 2009). Although such findings are of interest towards understanding the human health effects of CNTs, extreme caution should be taken in regards to the conclusions drawn since the doses applied were relatively high, probably causing an overload situation and furthermore, were arguably unrealistic in terms of possible human exposure, especially considering the findings of Maynard and coworkers (Maynard et al. 2004). The potential underlying mechanisms of the behaviour of long fibres in the lung and parietal pleura is extensively reviewed by (Donaldson 2009; 2010a).

\subsection{SUMMARY}

The possibility to design ENMs with preferential physicochemical properties such as high electric or heat conductivity, increased catalytic activity, or mechanical resistance, make nanomaterials the future investments for companies in order to implement their usage both for industrial, commercial and biomedical applications. The increasing use of ENMs has also 
resulted in an increasing awareness for the potential adverse effects of ENMs. There are clear indications that after inhalation and oral exposure ENMs can become systemically available. The uptake as percentage of administered dose is not always determined in the various studies, but seems in general to be rather low with exception for the oral route, for which the uptake might be considerable depending on the actual composition of the ENM preparation. Some studies indicate that smaller ENMs are more easily taken up and show a more widespread organ distribution. However, for the Gl-tract the effect of size is less clear. When systemically available, the main target organs are those with a high RES content, being mainly liver, spleen and lung, but ENMs have been demonstrated to distribute to other organs as well.

The potential toxicity of ENMs has been demonstrated in numerous in vitro studies. Information on in vivo toxicity and human epidemiological studies is mainly limited to inhalation exposure. There is sufficient evidence that acute inhalation exposure to high levels of ENMs may lead to adverse inflammatory effects in the lung. At the moment insufficient information exists on potential effects of chronic exposure to low levels of ENMs, by exposure via routes other than inhalation, and toxicity endpoints such as carcinogenicity, reproductive toxicity and immunotoxicity.

\section{OBJECTIVES AND OUTLINE OF THE THESIS}

Due to the fact that ENMs may have different biological activities compared to bulk material, their risks should be assessed separately. Nevertheless, it is both undesirable from an animal welfare point of view and unrealistic in terms of time and resources for industry and regulators to make a separate evaluation of the safety of every single different type of ENM, requiring a whole arsenal of experimental animal studies for each assessment. The main aim of this thesis is therefore to aid the risk assessment of ENMs, by means of the following three approaches:

\section{1) Evaluate the value of in vitro assays for risk assessment of ENMs.}

One way forward in the risk assessment procedures of ENMs would be to enhance the role of in vitro toxicity studies. In Chapter 2, a comparative analysis of published in vitro data with ENMs is given, revealing a number of issues that require attention when using in vitro assays as a screening approach to determine which ENMs are more hazardous than others.

\section{2) Investigate the possibility to extrapolate safety data between particles of different sizes}

The common denominator that sets ENMs apart from other materials is their scale. NPs have the capability to cross biological barriers and reach cells and tissues which were not 
exposed by their macroscopic form, and there are clear indications that after inhalation and oral exposure ENMs can become systematically available. Yet, the role of particle size in the biological response to ENMs is not entirely clear. In Chapter 3 to 6, the role of particle size in 'systemically relevant' in vitro assays for cytotoxicity, inflammation, inhibition of stem cell differentiation and genotoxicity is investigated for two of the most commonly used ENMs in consumer products: silica $\left(\mathrm{SiO}_{2}\right)$ and silver $(\mathrm{Ag}) \mathrm{NPs}$. A solid understanding of the role of particle size in various biological responses may help determine whether it is possible to extrapolate safety data between particles of different sizes.

\section{3) Evaluate various dose metrics of ENMs}

Doses in safety studies and exposure limits for 'ordinary' chemicals are generally based on mass concentrations. However, for different ENMs of the same chemical composition, the mass concentration leading to a specific critical effect may be very different from one ENM to another. It is expected that ENMs consisting of smaller NPs will have a larger surface area and a larger number of particles compared to ENMs consisting of larger NPs, and this will affect their biological activity. This leaves regulators with the problematic situation where one exposure limit based on mass is not appropriate for all ENMs consisting of the same chemical composition. It has therefore been suggested that particle number or surface area concentrations may be more appropriate metrics for ENMs to describe doses for regulatory purposes, but there is no consensus on which one of these is most appropriate. In Chapter 7, a graphical method to systematically investigate dose metrics of NPs is presented, and applied to data from in vitro studies with $\mathrm{SiO}_{2}$ and $\mathrm{Ag} \mathrm{NPs}$ described in Chapter 5 and 6. This method helps to understand whether mass, particle number, surface area or an entirely different metric is appropriate to describe the dose of ENMs for regulatory purposes. 


\section{REFERENCES}

Aggarwal P, Hall JB, McLeland CB, Dobrovolskaia MA, McNeil SE. 2009. Nanoparticle interaction with plasma proteins as it relates to particle biodistribution, biocompatibility and therapeutic efficacy. Adv Drug Deliv Rev 61(6):428-37.

Akiyama Y, Mori T, Katayama Y, Niidome T. 2009. The effects of PEG grafting level and injection dose on gold nanorod biodistribution in the tumor-bearing mice. J Control Release 139(1):81-4.

Auffan M, Rose J, Bottero JY, Lowry GV, Jolivet JP, Wiesner MR. 2009. Towards a definition of inorganic nanoparticles from an environmental, health and safety perspective. Nat Nanotechnol 4(10):634-41.

Ayres JG, Borm P, Cassee FR, Castranova V, Donaldson K, Ghio A, Harrison RM, Hider R, Kelly F, Kooter IM et al. 2008. Evaluating the toxicity of airborne particulate matter and nanoparticles by measuring oxidative stress potential--a workshop report and consensus statement. Inhal Toxicol 20(1):75-99.

Balogh L, Nigavekar SS, Nair BM, Lesniak W, Zhang C, Sung LY, Kariapper MS, El-Jawahri A, Llanes $\mathrm{M}$, Bolton B et al. 2007. Significant effect of size on the in vivo biodistribution of gold composite nanodevices in mouse tumor models. Nanomedicine 3(4):281-96.

Bertolazzi P, Guerra C, Liuzzi G. 2010. A global optimization algorithm for protein surface alignment. BMC Bioinformatics 11:488.

Borm PJ, Robbins D, Haubold S, Kuhlbusch T, Fissan H, Donaldson K, Schins R, Stone V, Kreyling W, Lademann J et al. 2006. The potential risks of nanomaterials: a review carried out for ECETOC. Part Fibre Toxicol 3:11.

Bowman K, Leong KW. 2006. Chitosan nanoparticles for oral drug and gene delivery. Int J Nanomedicine 1(2):117-28.

Brook RD, Rajagopalan S, Pope CA, 3rd, Brook JR, Bhatnagar A, Diez-Roux AV, Holguin F, Hong Y, Luepker RV, Mittleman MA et al. 2010. Particulate matter air pollution and cardiovascular disease: An update to the scientific statement from the American Heart Association. Circulation 121(21):2331-78.

Cabaleiro-Lago C, Lynch I, Dawson KA, Linse S. 2010. Inhibition of IAPP and IAPP(20-29) fibrillation by polymeric nanoparticles. Langmuir 26(5):3453-61.

Carlson C, Hussain SM, Schrand AM, Braydich-Stolle LK, Hess KL, Jones RL, Schlager JJ. 2008. Unique cellular interaction of silver nanoparticles: size-dependent generation of reactive oxygen species. J Phys Chem B 112(43):13608-19.

Cedervall T, Lynch I, Foy M, Berggard T, Donnelly SC, Cagney G, Linse S, Dawson KA. 2007. Detailed identification of plasma proteins adsorbed on copolymer nanoparticles. Angew Chem Int Ed Engl 46(30):5754-6.

Cho WS, Duffin R, Poland CA, Howie SE, MacNee W, Bradley M, Megson IL, Donaldson K. 2010. Metal oxide nanoparticles induce unique inflammatory footprints in the lung: important implications for nanoparticle testing. Environ Health Perspect 118(12):1699-706.

Choi HS, Liu W, Misra P, Tanaka E, Zimmer JP, Itty Ipe B, Bawendi MG, Frangioni JV. 2007. Renal clearance of quantum dots. Nat Biotechnol 25(10):1165-70.

Colognato R, Bonelli A, Ponti J, Farina M, Bergamaschi E, Sabbioni E, Migliore L. 2008. Comparative genotoxicity of cobalt nanoparticles and ions on human peripheral leukocytes in vitro. Mutagenesis 23(5):377-82.

Conner SD, Schmid SL. 2003. Regulated portals of entry into the cell. Nature 422(6927):37-44.

De Haar C, Hassing I, Bol M, Bleumink R, Pieters R. 2006. Ultrafine but not fine particulate matter 
causes airway inflammation and allergic airway sensitization to co-administered antigen in mice. Clin Exp Allergy 36(11):1469-79.

De Jong WH, Borm PJ. 2008. Drug delivery and nanoparticles:applications and hazards. Int J Nanomedicine 3(2):133-49.

De Jong WH, Hagens WI, Krystek P, Burger MC, Sips AJ, Geertsma RE. 2008. Particle size-dependent organ distribution of gold nanoparticles after intravenous administration. Biomaterials 29(12):1912-9.

Dell'Orco D, Lundqvist M, Oslakovic C, Cedervall T, Linse S. 2010. Modeling the time evolution of the nanoparticle-protein corona in a body fluid. PLoS One 5(6):e10949.

Dimkpa CO, Calder A, Britt DW, McLean JE, Anderson AJ. 2011. Responses of a soil bacterium, Pseudomonas chlororaphis 06 to commercial metal oxide nanoparticles compared with responses to metal ions. Environ Pollut 159(7):1749-56.

Dobrovolskaia MA, McNeil SE. 2007. Immunological properties of engineered nanomaterials. Nat Nanotechnol 2(8):469-78.

Dobrovolskaia MA, Patri AK, Zheng J, Clogston JD, Ayub N, Aggarwal P, Neun BW, Hall JB, McNeil SE. 2009. Interaction of colloidal gold nanoparticles with human blood: effects on particle size and analysis of plasma protein binding profiles. Nanomedicine 5(2):106-17.

Donaldson K. 2009. The inhalation toxicology of p-aramid fibrils. Crit Rev Toxicol 39(6):487-500.

Donaldson K, Murphy FA, Duffin R, Poland CA. 2010a. Asbestos, carbon nanotubes and the pleural mesothelium: a review of the hypothesis regarding the role of long fibre retention in the parietal pleura, inflammation and mesothelioma. Part Fibre Toxicol 7:5.

Donaldson K, Poland CA, Schins RP. 2010b. Possible genotoxic mechanisms of nanoparticles: criteria for improved test strategies. Nanotoxicology 4:414-20.

Duffin R, Tran L, Brown D, Stone V, Donaldson K. 2007. Proinflammogenic effects of low-toxicity and metal nanoparticles in vivo and in vitro: highlighting the role of particle surface area and surface reactivity. Inhal Toxicol 19(10):849-56.

Duncan R. 2006. Polymer conjugates as anticancer nanomedicines. Nat Rev Cancer 6(9):688-701.

Dutta D, Sundaram SK, Teeguarden JG, Riley BJ, Fifield LS, Jacobs JM, Addleman SR, Kaysen GA, Moudgil BM, Weber TJ. 2007. Adsorbed proteins influence the biological activity and molecular targeting of nanomaterials. Toxicol Sci 100(1):303-15.

EC. 2004. Towards a European Strategy for Nanotechnology, COM (2004) 338.

EC. 2009. REGULATION (EC) No 1223/2009 OF THE EUROPEAN PARLIAMENT AND OF THE COUNCIL of 30 November 2009 on cosmetic products. Official Journal of the European Commission L342/59(European Commission, Brussels, Belgium. Available from: http://eur-lex.europa.eu/ LexUriServ/LexUriServ.do?uri=OJ:L:2009:342:0059:0209:EN:PDF).

El Badawy AM, Silva RG, Morris B, Scheckel KG, Suidan MT, Tolaymat TM. 2011. Surface chargedependent toxicity of silver nanoparticles. Environ Sci Technol 45(1):283-7.

Ema M, Kobayashi N, Naya M, Hanai S, Nakanishi J. 2010. Reproductive and developmental toxicity studies of manufactured nanomaterials. Reprod Toxicol 30(3):343-52.

Fabian E, Landsiedel R, Ma-Hock L, Wiench K, Wohlleben W, van Ravenzwaay B. 2008. Tissue distribution and toxicity of intravenously administered titanium dioxide nanoparticles in rats. Arch Toxicol 82(3):151-7.

Feynman R. 1960. There's plenty of room at the bottom. Caltech Engineering and Science 23(5):2236. Available from: http://www.zyvex.com/nanotech/feynman.html. 
Gasser M, Rothen-Rutishauser B, Krug HF, Gehr P, Nelle M, Yan B, Wick P. 2010. The adsorption of biomolecules to multi-walled carbon nanotubes is influenced by both pulmonary surfactant lipids and surface chemistry. J Nanobiotechnology 8:31.

Geiser M, Rothen-Rutishauser B, Kapp N, Schurch S, Kreyling W, Schulz H, Semmler M, Im Hof V, Heyder J, Gehr P. 2005. Ultrafine particles cross cellular membranes by nonphagocytic mechanisms in lungs and in cultured cells. Environ Health Perspect 113(11):1555-60.

Gonzalez L, Lison D, Kirsch-Volders M. 2008. Genotoxicity of engineered nanomaterials: A critical review. Nanotoxicology 2(4):252-273.

Gosens I, Post JA, de la Fonteyne LJ, Jansen EH, Geus JW, Cassee FR, de Jong WH. 2010. Impact of agglomeration state of nano- and submicron sized gold particles on pulmonary inflammation. Part Fibre Toxicol 7(1):37.

Gulson B, McCall M, Korsch M, Gomez L, Casey P, Oytam Y, Taylor A, McCulloch M, Trotter J, Kinsley L et al. 2010. Small amounts of zinc from zinc oxide particles in sunscreens applied outdoors are absorbed through human skin. Toxicol Sci 118(1):140-9.

Hahn MA, Singh AK, Sharma P, Brown SC, Moudgil BM. 2011. Nanoparticles as contrast agents for in-vivo bioimaging: current status and future perspectives. Anal Bioanal Chem 399(1):3-27.

Health Canada. 2010. Interim policy statement on Health Canada's working definition for nanomaterials. Available from: http://www.hc-sc.gc.ca/sr-sr/alt_formats/pdf/consult/_2010/ nanomater/draft-ebauche-eng.pdf.

Hirn S, Semmler-Behnke M, Schleh C, Wenk A, Lipka J, Schaffler M, Takenaka S, Moller W, Schmid G, Simon $U$ et al. 2011. Particle size-dependent and surface charge-dependent biodistribution of gold nanoparticles after intravenous administration. Eur J Pharm Biopharm 77(3):407-16.

Hougaard KS, Fadeel B, Gulumian M, Kagan VE, Savolainen K. 2011. Developmental toxicity of engineered nanoparticles. In: Gupta RC, editor. Reproductive and developmental toxicology. London: Elsevier.

Hougaard KS, Jackson P, Jensen KA, Sloth JJ, Loschner K, Larsen EH, Birkedal RK, Vibenholt A, Boisen $\mathrm{AM}$, Wallin $\mathrm{H}$ et al. 2010. Effects of prenatal exposure to surface-coated nanosized titanium dioxide (UV-Titan). A study in mice. Part Fibre Toxicol 7:16.

Hsiao IL, Huang YJ. 2011. Effects of various physicochemical characteristics on the toxicities of ZnO and TiO nanoparticles toward human lung epithelial cells. Sci Total Environ 409(7):1219-28.

Inoue K, Takano H. 2011. Aggravating impact of nanoparticles on immune-mediated pulmonary inflammation. ScientificWorldJournal 11:382-90.

Irache JM, Esparza I, Gamazo C, Agueros M, Espuelas S. 2011. Nanomedicine: novel approaches in human and veterinary therapeutics. Vet Parasitol 180(1-2):47-71.

ISO. 2010. Nanotechnology-Vocabulary-Part 1. Core terms. ISO/TS 80004-1:2010. International Organization for Standardization, Geneva, Switzerland.

ISO. 2011. ISO/TC 229: Nanotechnologies. International Organization for Standardization, Geneva, Switzerland.

Jani PU, McCarthy DE, Florence AT. 1994. Titanium dioxide (rutile) particle uptake from the rat GI tract and translocation to systemic organs after oral administration. Int J Pharmaceutics 105:157-168.

Ji JH, Jung JH, Kim SS, Yoon JU, Park JD, Choi BS, Chung YH, Kwon IH, Jeong J, Han BS et al. 2007. Twenty-eight-day inhalation toxicity study of silver nanoparticles in Sprague-Dawley rats. Inhal Toxicol 19(10):857-71. 
Johnston HJ, Hutchison GR, Christensen FM, Aschberger K, Stone V. 2010. The biological mechanisms and physicochemical characteristics responsible for driving fullerene toxicity. Toxicol Sci 114(2):162-82.

Kanno S, Furuyama A, Hirano S. 2007. A murine scavenger receptor MARCO recognizes polystyrene nanoparticles. Toxicol Sci 97(2):398-406.

Kasper J, Hermanns MI, Bantz C, Maskos M, Stauber R, Pohl C, Unger RE, Kirkpatrick JC. 2011. Inflammatory and cytotoxic responses of an alveolar-capillary coculture model to silica nanoparticles: comparison with conventional monocultures. Part Fibre Toxicol 8(1):6.

Kim YS, Kim JS, Cho HS, Rha DS, Kim JM, Park JD, Choi BS, Lim R, Chang HK, Chung YH et al. 2008. Twenty-eight-day oral toxicity, genotoxicity, and gender-related tissue distribution of silver nanoparticles in Sprague-Dawley rats. Inhal Toxicol 20(6):575-83.

Kocbach A, Li Y, Yttri KE, Cassee FR, Schwarze PE, Namork E. 2006. Physicochemical characterisation of combustion particles from vehicle exhaust and residential wood smoke. Part Fibre Toxicol 3:1.

Kramer PA. 1974. Albumin microspheres as vehicles for achieving specificity in drug delivery. J Pharm Sci:1646-1647.

Kreyling WG, Semmler M, Erbe F, Mayer P, Takenaka S, Schulz H, Oberdorster G, Ziesenis A. 2002. Translocation of ultrafine insoluble iridium particles from lung epithelium to extrapulmonary organs is size dependent but very low. J Toxicol Environ Health A 65(20):1513-30.

Krug HF, Wick P. 2011. Nanotoxicology: an interdisciplinary challenge. Angew Chem Int Ed Engl 50(6):1260-78.

Lacerda SH, Park JJ, Meuse C, Pristinski D, Becker ML, Karim A, Douglas JF. 2010. Interaction of gold nanoparticles with common human blood proteins. ACS Nano 4(1):365-79.

Landsiedel R, Kapp MD, Schulz M, Wiench K, Oesch F. 2009. Genotoxicity investigations on nanomaterials: methods, preparation and characterization of test material, potential artifacts and limitations--many questions, some answers. Mutat Res 681(2-3):241-58.

Lankveld DP, Oomen AG, Krystek P, Neigh A, Troost-de Jong A, Noorlander CW, Van Eijkeren JC, Geertsma RE, De Jong WH. 2010. The kinetics of the tissue distribution of silver nanoparticles of different sizes. Biomaterials 31(32):8350-8361.

Lankveld DP, Rayavarapu RG, Krystek P, Oomen AG, Verharen HW, van Leeuwen TG, De Jong WH, Manohar S. 2011. Blood clearance and tissue distribution of PEGylated and non-PEGylated gold nanorods after intravenous administration in rats. Nanomedicine (Lond) 6(2):339-49.

Larese Filon F, Crosera M, Adami G, Bovenzi M, Rossi F, Maina G. 2011. Human skin penetration of gold nanoparticles through intact and damaged skin. Nanotoxicology 5:493-501.

Limbach LK, Li Y, Grass RN, Brunner TJ, Hintermann MA, Muller M, Gunther D, Stark WJ. 2005. Oxide nanoparticle uptake in human lung fibroblasts: effects of particle size, agglomeration, and diffusion at low concentrations. Environ Sci Technol 39(23):9370-6.

Limbach LK, Wick P, Manser P, Grass RN, Bruinink A, Stark WJ. 2007. Exposure of engineered nanoparticles to human lung epithelial cells: influence of chemical composition and catalytic activity on oxidative stress. Environ Sci Technol 41(11):4158-63.

Lipka J, Semmler-Behnke M, Sperling RA, Wenk A, Takenaka S, Schleh C, Kissel T, Parak WJ, Kreyling WG. 2010. Biodistribution of PEG-modified gold nanoparticles following intratracheal instillation and intravenous injection. Biomaterials 31(25):6574-81.

Lundqvist M, Stigler J, Elia G, Lynch I, Cedervall T, Dawson KA. 2008. Nanoparticle size and surface properties determine the protein corona with possible implications for biological impacts. Proc Natl Acad Sci U S A 105(38):14265-70. 
Lynch I, Salvati A, Dawson KA. 2009. Protein-nanoparticle interactions: What does the cell see? Nat Nanotechnol 4(9):546-7.

Madl AK, Pinkerton KE. 2009. Health effects of inhaled engineered and incidental nanoparticles. Crit Rev Toxicol 39(8):629-58.

Maynard AD, Baron PA, Foley M, Shvedova AA, Kisin ER, Castranova V. 2004. Exposure to carbon nanotube material: aerosol release during the handling of unrefined single-walled carbon nanotube material. J Toxicol Environ Health A 67(1):87-107.

McNeil SE. 2009. Nanoparticle therapeutics: a personal perspective. Wiley Interdiscip Rev Nanomed Nanobiotechnol 1(3):264-71.

Migliore L, Saracino D, Bonelli A, Colognato R, D’Errico MR, Magrini A, Bergamaschi A, Bergamaschi E. 2010. Carbon nanotubes induce oxidative DNA damage in RAW 264.7 cells. Environ Mol Mutagen 51(4):294-303.

Mitchell LA, Lauer FT, Burchiel SW, McDonald JD. 2009. Mechanisms for how inhaled multiwalled carbon nanotubes suppress systemic immune function in mice. Nat Nanotechnol 4(7):451-6.

Muchow M, Maincent P, Muller RH. 2008. Lipid nanoparticles with a solid matrix (SLN, NLC, LDC) for oral drug delivery. Drug Dev Ind Pharm 34(12):1394-405.

Nabeshi H, Yoshikawa T, Matsuyama K, Nakazato Y, Matsuo K, Arimori A, Isobe M, Tochigi S, Kondoh $S$, Hirai $T$ et al. 2011. Systemic distribution, nuclear entry and cytotoxicity of amorphous nanosilica following topical application. Biomaterials 32(11):2713-24.

Napierska D, Thomassen LC, Lison D, Martens JA, Hoet PH. 2010. The nanosilica hazard: another variable entity. Part Fibre Toxicol 7(1):39.

Nel A, Xia T, Madler L, Li N. 2006. Toxic potential of materials at the nanolevel. Science 311(5761):622-7. Nel AE, Madler L, Velegol D, Xia T, Hoek EM, Somasundaran P, Klaessig F, Castranova V, Thompson

M. 2009. Understanding biophysicochemical interactions at the nano-bio interface. Nat Mater 8(7):543-57.

NICNAS. 2010. Guidance on new chemical requirements for notification of industrial nanomaterials. National Industrial Chemicals Notification and Assessment Scheme Available from: http://www. nicnas.gov.au/Current_Issues/Nanotechnology/Guidance\%20on\%20New\%20Chemical\%20 Requirements\%20for\%20Notification\%200f\%20Industrial\%20Nanomaterials.pdf.

NIOSH. 2009. Approaches to Safe Nanotechnology. National Institute for Occupational Safety and Health, Atlanta, USA.

NIOSH. 2011. Occupational exposure to titanium dioxide. Current Intelligence Bulletin 63:Publication No 2011-160. Available from: http://www.cdc.gov/niosh/docs/2011-160/ pdfs/2011-160.pdf.

Nobs L, Buchegger F, Gurny R, Allemann E. 2004. Poly(lactic acid) nanoparticles labeled with biologically active Neutravidin for active targeting. Eur J Pharm Biopharm 58(3):483-90.

Oberdorster G. 2010. Safety assessment for nanotechnology and nanomedicine: concepts of nanotoxicology. J Intern Med 267(1):89-105.

Oberdorster G, Maynard A, Donaldson K, Castranova V, Fitzpatrick J, Ausman K, Carter J, Karn B, Kreyling W, Lai D et al. 2005a. Principles for characterizing the potential human health effects from exposure to nanomaterials: elements of a screening strategy. Part Fibre Toxicol 2:8.

Oberdorster G, Oberdorster E, Oberdorster J. 2005b. Nanotoxicology: an emerging discipline evolving from studies of ultrafine particles. Environ Health Perspect 113(7):823-39. 
OECD. 2008. Guidance for the use of the OECD database on research into the safety of manufactured nanomaterials. OECD Working Party on Manufactured Nanomaterials Available from: http:// www.oecd.org/dataoecd/21/19/44033847.pdf

Pal S, Tak YK, Song JM. 2007. Does the antibacterial activity of silver nanoparticles depend on the shape of the nanoparticle? A study of the Gram-negative bacterium Escherichia coli. Appl Environ Microbiol 73(6):1712-20.

Park EJ, Bae E, Yi J, Kim Y, Choi K, Lee SH, Yoon J, Lee BC, Park K. 2010a. Repeated-dose toxicity and inflammatory responses in mice by oral administration of silver nanoparticles. Environ Toxicol Pharmacol 30(2):162-8.

Park EJ, Yi J, Kim Y, Choi K, Park K. 2010b. Silver nanoparticles induce cytotoxicity by a Trojan-horse type mechanism. Toxicol In Vitro 24(3):872-8.

Pauluhn J. 2009. Retrospective analysis of 4-week inhalation studies in rats with focus on fate and pulmonary toxicity of two nanosized aluminum oxyhydroxides (boehmite) and pigment-grade iron oxide (magnetite): the key metric of dose is particle mass and not particle surface area. Toxicology 259(3):140-8.

Pauluhn J. 2011. Poorly soluble particulates: searching for a unifying denominator of nanoparticles and fine particles for DNEL estimation. Toxicology 279(1-3):176-88.

Powell JJ, Faria N, Thomas-McKay E, Pele LC. 2010. Origin and fate of dietary nanoparticles and microparticles in the gastrointestinal tract. J Autoimmun 34(3):J226-33.

Prinzen L, Miserus RJ, Dirksen A, Hackeng TM, Deckers N, Bitsch NJ, Megens RT, Douma K, Heemskerk JW, Kooi ME et al. 2007. Optical and magnetic resonance imaging of cell death and platelet activation using annexin a5-functionalized quantum dots. Nano Lett 7(1):93-100.

Rothen-Rutishauser BM, Schurch S, Haenni B, Kapp N, Gehr P. 2006. Interaction of fine particles and nanoparticles with red blood cells visualized with advanced microscopic techniques. Environ Sci Technol 40(14):4353-9.

Ryman-Rasmussen JP, Cesta MF, Brody AR, Shipley-Phillips JK, Everitt JI, Tewksbury EW, Moss OR, Wong BA, Dodd DE, Andersen ME et al. 2009. Inhaled carbon nanotubes reach the subpleural tissue in mice. Nat Nanotechnol 4(11):747-51.

Ryman-Rasmussen JP, Riviere JE, Monteiro-Riviere NA. 2006. Penetration of intact skin by quantum dots with diverse physicochemical properties. Toxicol Sci 91(1):159-65.

Sadauskas E, Wallin H, Stoltenberg M, Vogel U, Doering P, Larsen A, Danscher G. 2007. Kupffer cells are central in the removal of nanoparticles from the organism. Part Fibre Toxicol 4:10.

Sager TM, Castranova V. 2009. Surface area of particle administered versus mass in determining the pulmonary toxicity of ultrafine and fine carbon black: comparison to ultrafine titanium dioxide. Part Fibre Toxicol 6:15.

SCENIHR. 2010. Opinion on the scientific basis for the definition of the term "nanomaterial". European Commission, Brussels, Belgium. Available from: http://ec.europa.eu/health/ scientific_committees/emerging/docs/scenihr_o_032.pdf.

Schaeublin NM, Braydich-Stolle LK, Schrand AM, Miller JM, Hutchison J, Schlager JJ, Hussain SM. 2011. Surface charge of gold nanoparticles mediates mechanism of toxicity. Nanoscale 3(2):410-20.

Scheffel U, Rhodes BATK, Natarajan TK, Wagner Jr HN. 1973. Albumin microspheres for study of the reticuloendothelial system. J Nucl Med 13:498-503.

Schleh C, Rothen-Rutishauser B, Kreyling WG. 2011. The influence of pulmonary surfactant on nanoparticulate drug delivery systems. Eur J Pharm Biopharm 77(3):350-2. 
Semmler-Behnke M, Kreyling WG, Lipka J, Fertsch S, Wenk A, Takenaka S, Schmid G, Brandau W. 2008. Biodistribution of 1.4- and 18-nm gold particles in rats. Small 4(12):2108-11.

Shah PS, Balkhair T. 2011. Air pollution and birth outcomes: a systematic review. Environ Int 37(2):498-516.

Shi Y, Zhang JH, Jiang M, Zhu LH, Tan HQ, Lu B. 2010. Synergistic genotoxicity caused by low concentration of titanium dioxide nanoparticles and $p, p^{\prime}$-DDT in human hepatocytes. Environ Mol Mutagen 51(3):192-204.

Simko M, Mattsson MO. 2010. Risks from accidental exposures to engineered nanoparticles and neurological health effects: a critical review. Part Fibre Toxicol 7:42.

Singh N, Manshian B, Jenkins GJ, Griffiths SM, Williams PM, Maffeis TG, Wright CJ, Doak SH. 2009. NanoGenotoxicology: the DNA damaging potential of engineered nanomaterials. Biomaterials 30(23-24):3891-914.

Smijs TG, Bouwstra JA. 2010. Focus on skin as a possible port of entry for solid nanoparticles and the toxicological impact. J Biomed Nanotechnol 6(5):469-84.

Speiser P, Khanna SC. 1970. Perlpolymerisate, eine neue perorale Darreichungsform und ihre Beeinflussung durch Arzneistoffe. Praepar. Pharm 6:1-4.

Studer AM, Limbach LK, Van Duc L, Krumeich F, Athanassiou EK, Gerber LC, Moch H, Stark WJ. 2010. Nanoparticle cytotoxicity depends on intracellular solubility: comparison of stabilized copper metal and degradable copper oxide nanoparticles. Toxicol Lett 197(3):169-74.

Sugibayashi K, Morimoto Y, Nadai T, Kato Y, Hasegawa A, Arita T. 1979. Drug-carrier property of albumin microspheres in chemotherapy.Il. Preparation and tissue distribution in mice of microsphere-entrapped 5- fluorouracil Chem Pharm Bull 27:204-209.

Sung JH, Ji JH, Park JD, Song MY, Song KS, Ryu HR, Yoon JU, Jeon KS, Jeong J, Han BS et al. 2011. Subchronic inhalation toxicity of gold nanoparticles. Part Fibre Toxicol 8:16.

Sung JH, Ji JH, Park JD, Yoon JU, Kim DS, Jeon KS, Song MY, Jeong J, Han BS, Han JH et al. 2009. Subchronic inhalation toxicity of silver nanoparticles. Toxicol Sci 108(2):452-61.

Tang J, Xiong L, Wang S, Wang J, Liu L, Li J, Yuan F, Xi T. 2009. Distribution, translocation and accumulation of silver nanoparticles in rats. J Nanosci Nanotechnol 9(8):4924-32.

Tarantola M, Pietuch A, Schneider D, Rother J, Sunnick E, Rosman C, Pierrat S, Sonnichsen C, Wegener J, Janshoff A. 2011. Toxicity of gold-nanoparticles: synergistic effects of shape and surface functionalization on micromotility of epithelial cells. Nanotoxicology 5(2):254-68.

Tsuji JS, Maynard AD, Howard PC, James JT, Lam CW, Warheit DB, Santamaria AB. 2006. Research strategies for safety evaluation of nanomaterials, part IV: risk assessment of nanoparticles. Toxicol Sci 89(1):42-50.

US-FDA. 2011. Draft Guidance: Considering Whether an FDA-Regulated Product Involves the Application of Nanotechnology. United States Food and Drug Administration, Silver Spring, MD, USA. Available from: http://www.fda.gov/ScienceResearch/SpecialTopics/Nanotechnology/ ucm257926.htm.

Von Maltzahn G, Park JH, Agrawal A, Bandaru NK, Das SK, Sailor MJ, Bhatia SN. 2009. Computationally guided photothermal tumor therapy using long-circulating gold nanorod antennas. Cancer Res 69(9):3892-900.

Wang J, Zhou G, Chen C, Yu H, Wang T, Ma Y, Jia G, Gao Y, Li B, Sun J et al. 2007. Acute toxicity and biodistribution of different sized titanium dioxide particles in mice after oral administration. Toxicol Lett 168(2):176-85. 
Warheit DB. 2010. Debunking Some Misconceptions about Nanotoxicology. Nano Lett.

Weissenbock A, Wirth M, Gabor F. 2004. WGA-grafted PLGA-nanospheres: preparation and association with Caco-2 single cells. J Control Release 99(3):383-92.

Wick P, Malek A, Manser P, Meili D, Maeder-Althaus X, Diener L, Diener PA, Zisch A, Krug HF, von Mandach U. 2010. Barrier capacity of human placenta for nanosized materials. Environ Health Perspect 118(3):432-6.

Wick P, Manser P, Limbach LK, Dettlaff-Weglikowska U, Krumeich F, Roth S, Stark WJ, Bruinink A. 2007. The degree and kind of agglomeration affect carbon nanotube cytotoxicity. Toxicol Lett 168(2):121-31.

Wijnhoven SWP, Peijnenburg WJGM, Herberts CA, Hagens WI, Oomen AG, Heugens EHW, Roszek B, Bisschops J, Gosens I, Van De Meent D et al. 2009. Nano-silver - a review of available data and knowledge gaps in human and environmental risk assessment. Nanotoxicology 3(2):109-138.

Woodrow Wilson International Center for Scholars 2010. An inventory of nanotechnology-based consumer products currently on the market [internet]. 2006 March - [cited 2009 October]. Available from: http://www.nanotechproject.org/inventories/consumer/

Wu J, Liu W, Xue C, Zhou S, Lan F, Bi L, Xu H, Yang X, Zeng FD. 2009. Toxicity and penetration of $\mathrm{TiO}_{2}$ nanoparticles in hairless mice and porcine skin after subchronic dermal exposure. Toxicol Lett 191(1):1-8.

Xia T, Kovochich M, Brant J, Hotze M, Sempf J, Oberley T, Sioutas C, Yeh JI, Wiesner MR, Nel AE. 2006. Comparison of the abilities of ambient and manufactured nanoparticles to induce cellular toxicity according to an oxidative stress paradigm. Nano Lett 6(8):1794-807.

Xia T, Li N, Nel AE. 2009. Potential health impact of nanoparticles. Annu Rev Public Health 30:13750.

Xia T, Zhao Y, Sager T, George S, Pokhrel S, Li N, Schoenfeld D, Meng H, Lin S, Wang X et al. 2011. Decreased dissolution of $\mathrm{ZnO}$ by iron doping yields nanoparticles with reduced toxicity in the rodent lung and zebrafish embryos. ACS Nano 5(2):1223-35.

Yu LE, Yung L-YL, Ong C-N, Tan Y-L, Balasubramaniam KS, Hartono D, Shui G, Wenk MR, Ong W-Y. 2007. Translocation and effects of gold nanoparticles after inhalation exposure in rats. Nanotoxicology 1:235-242.

Zolnik BS, Gonzalez-Fernandez A, Sadrieh N, Dobrovolskaia MA. 2010. Nanoparticles and the immune system. Endocrinology 151(2):458-65. 




\section{CHAPTER 2}

\section{THE STATUS OF IN VITRO TOXICITY STUDIES IN RISK ASSESSMENT OF ENGINEERED NANOMATERIALS}

Margriet V.D.Z. Park ${ }^{1,2}$ Daniëlle P.K. Lankveld ${ }^{2}$ Henk van Loveren ${ }^{1,2}$ Wim H. de Jong ${ }^{2}$

Nanomedicine 4(6):669-685, 2009.

${ }^{1}$ Maastricht University, Department of Toxicogenomics, P.O. Box 616, 6200 MD Maastricht The Netherlands

${ }^{2}$ National Institute for Public Health and the Environment, Laboratory for Health Protection Research, P.O. Box 1, 3720 BA, Bilthoven, the Netherlands 


\section{ABSTRACT}

Nanotechnology applications, already on the market or in development, promise great benefits for humans as well as the environment. Simultaneously, the pressure to advance the development of fast methods for evaluating the potential risks of increased human exposure to ENMs is augmented. One way forward would be to enhance the role of in vitro toxicity studies in risk assessment procedures of ENMs. However, to maximize the use of in vitro assays for this purpose, their values and limitations need to be revealed. Even in risk assessment frameworks for regular chemicals, in vitro studies play a minor part. A comparative analysis of published in vitro data with ENMs demonstrates that there is a number of issues that need resolving before in vitro studies can play a role in risk assessment of ENMs.

\subsection{THE NEED FOR IN VITRO STUDIES IN RISK ASSESSMENT OF ENMS}

A vast variety of new materials is being developed by means of nanotechnology and is already applied in many every day products. It can be anticipated that human exposure to ENMs, both by the use of such products and via the environment, will be steadily increasing. The risks of ENMs may differ from their regular chemical counterparts due to their altered physical chemical properties (SCENIHR 2007). Traditional risk assessment procedures will unlikely be able to keep up with the rapid development of new ENMs and the cost, in terms of both money and animal lives, would be tremendous (Service 2008). On the other hand, the uncertainties that exist regarding the safety of applying nanotechnology may put a hold to marketing and further development of new and promising ENMs (Nel et al. 2006; Service 2008). For the moment, it is advocated that risk assessment requirements for a new nanotechnology application should be defined on a case by case basis (SCENIHR 2007). Once sufficient knowledge on the risks of ENMs becomes available, it is proposed that a risk assessment paradigm for ENMs can be developed, potentially with possibilities to extrapolate from one nanoform to another (SCENIHR 2007).

Screening ENMs by means of in vitro studies has been suggested by many as a fast approach to distinguish between low and high toxicity ENMs (Nel et al. 2006; Service 2008; Shaw et al. 2008). In vitro assays may also be useful to evaluate specific mechanistic pathways such as reactive and inflammation potential and cellular uptake of ENMs (Oberdorster et al. 2005; SCENIHR 2007). Ultimately, the aim is to develop a risk assessment paradigm consisting of a tiered approach, where potential toxic properties can be predicted based on physicochemical properties, a (limited) number of in vitro assays and no or a few in vivo assays. However, to be applicable as acceptable methods within risk assessment procedures, in vitro assays need to be validated and their relevance for in vivo hazard identification needs to be demonstrated (SCENIHR 2009). This paper provides 
an overview of in vitro assays commonly used in nanotoxicology research and factors that determine their outcome. Based on this overview, the potential for these in vitro studies to be used as validated tools within risk assessment of ENMs will be discussed.

\subsection{ASSAY PROTOCOL CHOICES INFLUENCING THE OUTCOME OF IN VITRO STUDIES WITH ENMS}

In vitro studies have revealed that subtle changes in size, shape, surface area, surface reactivity, solubility and crystal structure of ENMs may influence their cellular uptake and activity (Brunner et al. 2006; Duffin et al. 2007; Sayes et al. 2006; Yang et al. 2009). For example, titanium dioxide $\left(\mathrm{TiO}_{2}\right)$ nanoparticles in anatase form were found to be 100 times more cytotoxic than $\mathrm{TiO}_{2}$ in rutile form (Sayes et al. 2006). Consequently, it is increasingly emphasized that meaningful comparisons of experimental results across different studies are impossible without appropriate ENM characterization (Murdock et al. 2008; Warheit 2008). Much less consideration is given to the fact that experimental assay protocol choices may be equally if not more important than ENM characterization when comparing results across different studies. The influence of various assay protocol choices on the outcome of in vitro experiments with ENMs is illustrated by a number of recent comparative studies discussed below.

\subsubsection{Effect of exposure and dispersion methods on the outcome of in vitro studies}

Humans may be exposed to ENMs in many forms, including airborne nanoparticles, or ENMs embedded in liquid or solid matrices. In vitro assays mostly use systems where single cell cultures are exposed to ENMs dispersed in cell culture medium. This often does not mirror realistic exposure situations. For example, exposure of cells to ENMs dispersed in cell culture medium poorly reflects exposure in the lung, where cells are exposed to inhaled ENMs at the air-liquid interface. In addition, it has been shown that different lung cell types influence each other in their response to inhaled particle exposure (AlfaroMoreno et al. 2008; Herseth et al. 2008). A recent review describes many efforts done so far to overcome these problems, for example by the establishment of air-liquid exposure systems for ENMs and the use of co-culture systems (Rothen-Rutishauser et al. 2008). Nevertheless, not one single model appears to be adequate to completely replace animal and/or human experiments.

Another limitation of in vitro test systems is that ENMs need to be suspended in physiological solutions, which may not always correspond to the matrix in which the ENM occurs in its ultimate application. The characteristics of the matrix of a ENM, for example the $\mathrm{pH}$ and ionic strength of a ENM dispersion affects the aggregation status of ENMs (French et al. 2009). This in turn can be anticipated to play a major role in the extent of human exposure and the ultimate bioavailability of the ENMs. In general, dispersions of 
ENMs can be prepared in various ways, which result in differences in size distributions and stability of the ENMs. Factors that have been shown to affect dispersions are different dispersion media, ultrasound energies, various (concentrations of) dispersion stabilizers and different sequences of preparation steps (Bihari et al. 2008; Murdock et al. 2008). Possibly, size distribution and stability of the particles in turn affect the toxicity results of in vitro experiments.

Most in vitro toxicity studies with ENMs are carried out with sonificated ENMs suspended in standard cell culture medium containing 10\% fetal calf serum (FCS) (Brunner et al. 2006; Diaz et al. 2008; Park et al. 2008; Sayes et al. 2007; Sayes et al. 2006; Yamamoto et al. 2004). Sonification has been shown to reduce particle size and zeta potential in distilled water, although it is unknown whether these effects are lasting and whether toxic responses to ENMs are affected by sonification (Murdock et al. 2008). Dispersion of most ENMs in cell culture medium without serum considerably increased their agglomeration compared to dispersion in distilled water only (Monteiro-Riviere et al. 2009; Murdock et al. 2008). In contrast, the addition of serum or serum albumin to ENM dispersions has been shown to reduce agglomeration for most ENMs (Bihari et al. 2008; Foucaud et al. 2007; Murdock et al. 2008; Schulze et al. 2008). For example, the average hydrodynamic diameter of polysaccharide coated silver nanoparticles with primary size $10 \mathrm{~nm}$ dispersed in distilled water was $72.8 \mathrm{~nm}$, but increased to $431 \mathrm{~nm}$ when dispersed in RPMI cell culture medium. When $20 \%$ fetal bovine serum was added to the cell culture medium, the average hydrodynamic diameter decreased to $49.4 \mathrm{~nm}$ (Murdock et al. 2008). (Table 2.1). It is possible that components present in the serum pacify the ENM surface, as has been suggested for $\mathrm{TiO}_{2}$ (Xia et al. 2006). A limited number of studies have used dipalmitoyl phosphatidyl choline (DPPC), a phospholipid found in lung surfactant, to improve particle suspensions (Foucaud et al. 2007; Kang et al. 2008; Sager et al. 2007). The ROS production by carbon black ENMs was significantly increased when particle suspensions were improved by adding DPPC (Foucaud et al. 2007). In contrast, the cytotoxicity of Min-U-Sil 2 silica was not altered by the addition of DPPC to the dispersion medium, despite the improved particle suspension (Sager et al. 2007) (Table 2.1).

Several types of ENMs have been reported to adsorb proteins and micronutrients from their dispersion medium (Casey et al. 2008; Dutta et al. 2007; Guo et al. 2008). The amount of protein associated with the surface area of polystyrene particles (the 'protein corona') was shown to depend on the plasma concentration in the dispersion, while the composition of the proteins was reported to depend on the size and surface charge of the particles. Possibly, the composition of the proteins in the corona around nanoparticles is of influence on biological processes (Lundqvist et al. 2008). These findings in turn imply that the composition of the proteins in the dispersion medium may influence the results of in vitro toxicity studies. 


\begin{tabular}{|c|c|c|c|}
\hline Reference & Nanomaterial & Dispersion Method & Key findings \\
\hline $\begin{array}{l}\text { Aisaka et al. } \\
\text { (2008) }\end{array}$ & $\mathrm{TiO}_{2}$ & $\begin{array}{l}\text { Erythrocytes in isotonic } \\
\text { buffer, with or without } \\
\text { plasma, albumin or } \\
\text { Y-globulin }\end{array}$ & $\begin{array}{l}\text { Addition of less than } 2 \% \\
\text { serum, albumin or } \\
\gamma \text {-globulin almost } \\
\text { completely abolished } \\
\text { hemolysis caused by } \mathrm{TiO}_{2} \text {. }\end{array}$ \\
\hline $\begin{array}{l}\text { Foucaud et al. } \\
\text { (2007) }\end{array}$ & $\mathrm{CB}$ & $\begin{array}{l}\text { Cell culture medium with } \\
\text { or without Bovine Serum } \\
\text { Albumin BSA and/or DPPC }\end{array}$ & $\begin{array}{l}\text { Addition of BSA and DPPC } \\
\text { significantly increased ROS } \\
\text { formation in cells exposed } \\
\text { to CB. }\end{array}$ \\
\hline $\begin{array}{l}\text { Murdock et al. } \\
(2008)\end{array}$ & $\begin{array}{l}\mathrm{Al}, \mathrm{Al}_{2} \mathrm{O}_{3}, \mathrm{Ag} \\
\mathrm{Cu}, \mathrm{TiO}_{2}\end{array}$ & $\begin{array}{l}\text { Cell culture medium with or } \\
\text { without FCS }\end{array}$ & $\begin{array}{l}\text { Addition of serum } \\
\text { moderated cytotoxicity } \\
\text { caused by } \mathrm{Ag} \text { and } \mathrm{Cu} \text {, but did } \\
\text { not modify cell viability after } \\
\mathrm{Al}, \mathrm{Al}_{2} \mathrm{O}_{3} \text { or } \mathrm{TiO}_{2} \text { exposure. }\end{array}$ \\
\hline $\begin{array}{l}\text { Sager et al. } \\
(2007)\end{array}$ & $\mathrm{CS}^{\mathrm{a}}$ & $\begin{array}{l}\text { Serum-free cell culture } \\
\text { medium containing } \\
\text { CS suspended in } \\
\text { PBS, BALF or DPPC }\end{array}$ & $\begin{array}{l}\text { No significant differences } \\
\text { between different CS } \\
\text { suspensions on cytotoxicity. }\end{array}$ \\
\hline
\end{tabular}

${ }^{a}$ The material used in this study was Min-U-Sil quartz, which technically is not a nanomaterial, but fine sized crystalline silica.

$\mathrm{TiO}_{2}$ : titanium dioxide; $\mathrm{CB}$ : carbon black; Al: aluminum; $\mathrm{Al}_{2} \mathrm{O}_{3}$ : aluminum oxide; $\mathrm{Ag}$ : silver; $\mathrm{Cu}$ : copper; CS: crystalline silica; BSA: bovine serum albumin; DPPC: dipalmitoyl phosphatidyl choline; FCS: fetal calf serum; PBS: phosphate buffered saline; BALF: bronchoalveolar lavage fluid; ROS: reactive oxygen species.

Table 2.1 Comparison of in vitro toxicity results from studies with ENMs using two or more dispersion methods.

In summary, a major limitation of in vitro assays is that the exposure and dispersion methods mostly used do not adequately reflect the exposure as it occurs in vivo. Apart from simplified exposure systems, the inevitable use of physiological dispersion media may affect ENM characteristics and their biological impact. Often, interpretation of in vitro data is complex due to aggregation or agglomeration issues of ENMs in dispersion media. Sonification and the addition of serum or surfactants to ENM suspensions may improve particle dispersions by reducing their agglomeration. Addition of serum to the dispersion medium has been shown to decrease toxicity in in vitro studies, but this may be the result of pacifying the ENM surface rather than due to a better dispersion of the ENMs. Alternatively, the biological impact of ENMs may be governed by the type proteins in the dispersion, which associate with the surface of the ENMs. Clearly, exposure systems and dispersion methods need to be optimized for various ENMs to better reflect different in vivo routes of exposure. Until then, 
even for merely identifying potential hazards or studying the mechanism of action of ENMs, in vitro data needs to be interpreted with caution.

\subsubsection{Effect of endpoint readout system on outcome of in vitro toxicity studies}

Much of the research so far conducted on ENMs takes advantage of the vast knowledge already obtained from particulate matter research. Consequently, nanotoxicology research focuses mainly on the same toxicity endpoints: cytotoxicity, oxidative stress, inflammation and genotoxicity. Other toxicity endpoints such as reproductive and developmental toxicity, immunotoxicity, sensibilisation, and non-genotoxic carcinogenicity receive little or no attention, though these endpoints may well be relevant for many applications of ENMs. For cytotoxicity, oxidative stress, inflammation and genotoxicity, various readout systems exist and those that are most commonly used in nanotoxicology research will be discussed below.

\subsubsection{Cytotoxicity readout systems}

To date, the vast majority of in vitro studies performed with ENMs are cytotoxicity studies. Many different cytotoxicity assays are readily available as commercial test kits which are relatively easy to perform. The Interagency Coordinating Committee on the Validation of Alternative Methods (ICCVAM) evaluated the ability of a number of in vitro cytotoxicity test methods to predict appropriate starting doses for in vivo acute toxicity studies (ICCVAM 2001). The use of the neutral red uptake assay in combination with 3T3 cells was deemed most suitable for this specific purpose. Nevertheless, this assay is rarely used in nanotoxicology research compared to other assays. Cytotoxicity assays most encountered in studies with ENMs include tetrazolium salt (MTT and WST-1) cleavage assays, lactate dehydrogenase (LDH) assay, Trypan blue exclusion assay, and DNA contents assay. The outcome of these tests all correlate to the number of viable, active cells, although each test uses a different readout system. The MTT test and the WST-1 test are quite similar in that both tests involve the enzymatic reduction of tetrazolium salts into a formazan dye. However, there is an important difference between the MTT and the WST-1. The tetrazolium salt in the MTT test has a net positive charge and readily enters the cell where it can be metabolized by cellular enzymes. In contrast, the tetrazolium salt used in the WST-1 test has a net negative charge and is largely cell-impermeable. Its reduction most likely occurs at the cell surface, or at the level of the plasma membrane via trans-plasma membrane electron transport (Berridge et al. 2005). Nevertheless, the outcomes of both assay types correlate to the number of metabolically active cells. 


\begin{tabular}{lll} 
Reference & Nanomaterial & Readout system \\
\hline $\begin{array}{l}\text { Brunner et al. } \\
\text { (2006) }\end{array}$ & Asbestos, $\mathrm{SiO}_{2}$, & MTT, DNA in MSTO and \\
& $\mathrm{ZnO}, \mathrm{Fe}_{2} \mathrm{O}_{3}$, & $3 \mathrm{~T} 3$ cells \\
& $\mathrm{Ca}_{3}\left(\mathrm{PO}_{4}\right)_{2}, \mathrm{TiO}_{2}$, & \\
$\mathrm{CeO}_{2}, \mathrm{ZrO}_{2}$ &
\end{tabular}

Carlson et al. $\mathrm{Ag}$

Carlson
$(2008)$

\begin{tabular}{ll}
\hline Chang et al. $\quad \mathrm{SiO}_{2}, \mathrm{SiO}_{2}-$ chitosan & MTT, LDH in WS1, CCD- \\
(2007) & 996sk, MRC-5, A549, \\
& MKN-28, HT-29
\end{tabular}

\begin{tabular}{|c|c|c|}
\hline $\begin{array}{l}\text { Diaz et al. } \\
(2008)\end{array}$ & $\begin{array}{l}\text { Fe graphite, } \\
\text { magnetite } \mathrm{SiO}_{2} \\
\text { (PEG-ylated) } \mathrm{SiO}_{2}, \\
\text { magnetite } \mathrm{AlSiO}_{2}\end{array}$ & $\begin{array}{l}\text { MTT, Trypan Blue in } \\
\text { tumoral and normal } \\
\text { human blood cells }\end{array}$ \\
\hline $\begin{array}{l}\text { Hussain et al. } \\
(2005)\end{array}$ & $\begin{array}{l}\mathrm{CdO}, \mathrm{Ag}, \mathrm{MoO}_{3^{\prime}} \\
\mathrm{Fe}_{3} \mathrm{O}_{4^{\prime}} \mathrm{Al}, \mathrm{MnO}_{2}, \mathrm{~W}\end{array}$ & MTT, LDH in BRL3A \\
\hline
\end{tabular}

\section{Key findings}

Cytotoxicity results similar for both readout systems for all nanomaterials, except $\mathrm{ZrO}_{2}$ where results of DNA assay indicated cytotoxicity in 3 T3 cells after 3 days, but results of MTT assay did not.

MTT, LDH in alveolar macrophages readout systems, although
Cytotoxicity detected by both $\mathrm{EC}_{50}$ values were lower when calculated from LDH results.

Similar cytotoxicity to $\mathrm{SiO}_{2}$ detected by both readout systems. Both readout systems detected no cytotoxicity to $\mathrm{SiO}_{2}$ - chitosan. Results between readout systems did not correlate well for any of the nanomaterials.

For all nanomaterials, $\mathrm{EC}_{50}$ values calculated from results of MTT and LDH were less than a factor 2 apart.

\begin{tabular}{|c|c|c|c|}
\hline Jin et al. (2007) & Luminescent $\mathrm{SiO}_{2}$ & MTT, Trypan Blue in A549 & $\begin{array}{l}\text { Cytotoxicity detected at } \\
\text { similar concentrations by } \\
\text { both readout systems. }\end{array}$ \\
\hline $\begin{array}{l}\text { Lison et al. } \\
\text { (2008) }\end{array}$ & $\mathrm{SiO}_{2}$ & $\begin{array}{l}\text { MTT, LDH in A549, } \\
\text { EAHY926, J774 }\end{array}$ & $\begin{array}{l}\text { Very good agreements } \\
\text { between } \mathrm{EC}_{50} \text { values as } \\
\text { determined by MTT and LDH. }\end{array}$ \\
\hline $\begin{array}{l}\text { Monteiro- } \\
\text { Riviere et al. } \\
(2009)\end{array}$ & $\begin{array}{l}\text { CB, SWCNT, } C_{60} \\
\text { QD }\end{array}$ & $\begin{array}{l}\text { MTT, MTS, Trypan Blue, } \\
\text { LDH and others in HEK }\end{array}$ & $\begin{array}{l}\text { In general, presence or } \\
\text { absence of cytotoxicity } \\
\text { similarly detected by most } \\
\text { readout systems, but at } \\
\text { different concentrations. }\end{array}$ \\
\hline $\begin{array}{l}\text { Sayes et al. } \\
(2007)\end{array}$ & $\mathrm{Cl}, \mathrm{CS}^{\mathrm{a}}, \mathrm{SiO}_{2}, \mathrm{ZnO}^{\mathrm{b}}$ & $\begin{array}{l}\text { MTT, LDH in L2, AM and } \\
\text { co-culture }\end{array}$ & $\begin{array}{l}\text { Poor correlation between } \\
\text { results of readout systems } \\
\text { for all nanomaterials. }\end{array}$ \\
\hline
\end{tabular}




\begin{tabular}{|c|c|c|c|}
\hline Reference & Nanomaterial & Readout system & Key findings \\
\hline $\begin{array}{l}\text { Simon-Deckers } \\
\text { et al. (2008) }\end{array}$ & $\begin{array}{l}\text { MWCNT with Fe, } \\
\mathrm{Al}_{2} \mathrm{O}_{3}, \mathrm{TiO}_{2}\end{array}$ & $\begin{array}{l}\text { MTT, LDH and XTT in } \\
\text { A549 }\end{array}$ & $\begin{array}{l}\text { Cytotoxic effects of } \\
\text { nanomaterials apparent } \\
\text { after } 1 \text { hour of exposure as } \\
\text { measured with MTT, but only } \\
\text { after } 48 \text { hours of exposure } \\
\text { when measured with LDH or } \\
\text { XTT. }\end{array}$ \\
\hline $\begin{array}{l}\text { Wang et al. } \\
\text { (2007) }\end{array}$ & $\mathrm{TiO}_{2}$ & $\begin{array}{l}\text { MTT, Trypan Blue in } \\
\text { WIL2-NS }\end{array}$ & $\begin{array}{l}\text { Very well correlating } \\
\text { cytotoxicity findings between } \\
\text { readout systems. }\end{array}$ \\
\hline $\begin{array}{l}\text { Yang et al. } \\
\text { (2009) }\end{array}$ & $\mathrm{CB}, \mathrm{CNT}, \mathrm{CS}, \mathrm{ZnO}$ & MTT, WST, LDH in PMEF & $\begin{array}{l}\text { Findings of cytotoxicity } \\
\text { correlated well between } \\
\text { MTT and WST assays for } \mathrm{SiO}_{2} \\
\text { and } \mathrm{ZnO} \text {, but not for } \mathrm{CB} \text { and } \\
\text { CNT. In contrast to the MTT } \\
\text { and WST assay, there was no } \\
\text { statistical difference between } \\
\text { nanomaterials in the LDH } \\
\text { assay. }\end{array}$ \\
\hline
\end{tabular}

$\mathrm{SiO}_{2}$ : silica; $\mathrm{ZnO}$ : zinc oxide; $\mathrm{Fe}_{2} \mathrm{O}_{3}$ : iron oxide; $\mathrm{Ca}_{3}\left(\mathrm{PO}_{4}\right)_{2}$ : tricalcium phosphate, $\mathrm{TiO}_{2}$ : titanium dioxide, $\mathrm{CeO}_{2}$ : ceria; $\mathrm{ZrO}_{2}$ : zirconia; $\mathrm{Ag}$ : silver; $\mathrm{Zn}$ : zinc; $\mathrm{Si}$ : silicon; Fe: iron; PEG: polyethyleneglycol; $\mathrm{AlSiO}_{2}$ : aluminum silica; $\mathrm{CdO}$ : cadmium oxide; $\mathrm{MoO}_{3}$ : molybdenum; $\mathrm{Fe}_{3} \mathrm{O}_{4}$ : iron oxide; Al: aluminum; $\mathrm{MnO}_{2}$ : manganese oxide; W: tungsten; $\mathrm{CB}$ : carbon black; SWCNT: single walled carbon nanotube; $\mathrm{C}_{60}$ : fullerene; $\mathrm{QD}$ : quantum dot; $\mathrm{Cl}$ : carbonyl iron; $\mathrm{CS}$ : crystalline silica; MWCNT: multi-walled carbon nanotube; $\mathrm{Al}_{2} \mathrm{O}_{3}$ : aluminum oxide; CNT: carbon nanotube; MTT: 3-(4,5-Dimethylthiazol-2-yl)-2,5-diphenyltetrazolium bromide; MSTO: human mesothelioma cell; 3T3: rodent 3T3 fibroblast; WS1: human skin fibroblast; CCD-996sk: human skin fibroblast; MRC5: human lung fibroblast; A549: human lung epithelial cell; MKN-28: human gastric epithelial cell; HT-29: human colon epithelial cell; BRL3A: rat liver cell; EAHY926: human endothelium cell; J774: mouse monocyte-macrophage; HEK: human epidermal keratinocyte; L2: rat lung epithelial cell; AM: rat primary alveolar macrophage; XTT: sodium 3'-[1-(phenylaminocarbonyl)3,4-tetrazolium; WIL2-NS: human lymphoblastoid cell; PMEF: primary mouse embryo fibroblast; LDH: lactate dehydrogenase; MTS: 3-(4,5-dimethylthiazol-2-yl)-5-(3-carboxymethoxyphenyl)2-(4-sulfophenyl)-2H-tetrazolium. $\mathrm{EC}_{50}: 50 \%$ effective concentration, in this case exposure concentration resulting in $50 \%$ loss of viability compared to control.

Table 2.2 Comparison of in vitro cytotoxicity results from studies with ENMs using two or more different readout systems.

LDH and Trypan blue exclusion assays are both based on the integrity of the cell membrane. In the Trypan blue exclusion assay, blue dye enters dead and leaky cells, and the number 
of dyed cells is an indicator of cell death. In the LDH assay, LDH leaks out of dead and leaky cells and amount of LDH in cell culture medium is therefore inversely correlated to cell viability. Total LDH, measured after lysing the cells, is a measure of cell proliferation. Assays measuring DNA contents provide a direct correlation to the number of cells, but do not necessarily give information on the viability of the cells.

While many studies using two or more different cytotoxicity assays have reported reasonable agreement in the results (Brunner et al. 2006; Carlson et al. 2008; Chang et al. 2007; Hussain et al. 2005; Jin et al. 2007; Lison et al. 2008; Simon-Deckers et al. 2008; Wang et al. 2007; Yang et al. 2009), large discrepancies have also been reported (Diaz et al. 2008; Monteiro-Riviere et al. 2009; Sayes et al. 2007; Simon-Deckers et al. 2008) (Table 2.2). It is possible that ENMs affect one cytotoxicity endpoint, but not another. For example, the cell membrane of a cell undergoing apoptosis remains largely intact, and this type of toxicity may not be picked up by assays based on compromised membrane integrity such as the LDH. Discrepancies in results between different cytotoxicity assays may also be the result of incompatibility of certain assays with the ENMs or the cell types used, as will be discussed in more detail later.

Regardless of the cause, the large discrepancy frequently encountered between cytotoxicity assays with ENMs indicates that selection of the most appropriate readout system for risk assessment purposes is not a straightforward procedure, and likely differs for various ENMs.

\subsubsection{Oxidative stress and inflammation readout systems}

The role of oxidative stress in the toxicity of ambient and engineered ENMs and the pathways involved in a cellular oxidative stress response have been reviewed elsewhere (Li and Huang 2008; Nel et al. 2006; Xia et al. 2006). Briefly, ROS are generated by cells as by-products of normal cellular activity and are neutralized by cellular antioxidant defenses. Oxidative stress is induced if exposure of the cell to reactive oxygen species exceeds the neutralizing capacity of the cellular antioxidant defense. The cellular response during oxidative stress includes the induction of a number of redox-sensitive signaling cascades according to the following proposed three tiered model (Li and Huang 2008). At low levels of oxidative stress, the tier 1 protective 'phase 2 response' induces antioxidant enzymes such as glutathione $S$-transferase isoenzymes to restore redox homeostatis. A further increase in ROS production or a failure of the phase 2 response to provide adequate protection can result in proinflammatory (tier 2 ) and cytotoxic (tier 3 ) effects. Proinflammatory effects include the expression of cytokines, chemokines and adhesion molecules, while cytotoxic effects involve mitochondria which may release proapoptotic factors and induce apoptosis. 


\begin{tabular}{|c|c|c|c|}
\hline Reference & Nanomaterial & Readout system & Key findings \\
\hline $\begin{array}{l}\text { Carlson et al. } \\
(2008)\end{array}$ & $\mathrm{Ag}$ & $\begin{array}{l}\text { ROS, GSH } \\
\text { in alveolar } \\
\text { macrophages }\end{array}$ & $\begin{array}{l}15 \mathrm{~nm} \text { Ag significantly increased ROS } \\
\text { and decreased GSH, while } 55 \mathrm{~nm} \mathrm{Ag} \\
\text { did not. } 30 \mathrm{~nm} \text { Ag also decreased GSH } \\
\text { without increasing ROS. }\end{array}$ \\
\hline $\begin{array}{l}\text { Carlson et al. } \\
(2008)\end{array}$ & $\mathrm{Ag}$ & ROS, GSH in BLR3A & $\begin{array}{l}\text { Both } 15 \text { and } 100 \mathrm{~nm} \text { Ag similarly } \\
\text { increased ROS and decreased GSH. }\end{array}$ \\
\hline $\begin{array}{l}\text { Park et al. } \\
\text { (2008) }\end{array}$ & $\mathrm{CeO}_{2}$ & $\begin{array}{l}\text { ROS, GSH and } \\
\text { others in BEAS-2B }\end{array}$ & $\begin{array}{l}\mathrm{CeO}_{2} \text { increased ROS production, } \\
\text { decreased GSH levels and induced } \\
\text { oxidative stress related genes. }\end{array}$ \\
\hline $\begin{array}{l}\text { Yang et al. } \\
\text { (2009) }\end{array}$ & $\begin{array}{l}\mathrm{CB}, \mathrm{CNT}, \mathrm{CS}, \\
\mathrm{ZnO}\end{array}$ & $\begin{array}{l}\text { ROS, GSH and } \\
\text { others in PMEF }\end{array}$ & $\begin{array}{l}\text { Results of ROS and GSH correlated well } \\
\text { for } \mathrm{SiO}_{2} \text { and } \mathrm{ZnO} \text {, but less for } \mathrm{CB} \text { and } \\
\text { CNT. GSH results correlated well with } \\
\text { measurements of SOD activity and } \\
\text { MDA concentrations. }\end{array}$ \\
\hline
\end{tabular}

Ag: silver; $\mathrm{CeO}_{2}$ : ceria; $\mathrm{CB}$ : carbon black; $\mathrm{CNT}$ : carbon nanotubes; $\mathrm{CS}$ : crystalline silica, ZnO: zinc oxide; ROS: reactive oxygen species; GSH: reduced glutathione; BLR3A: rat liver cell; BEAS-2B: human bronchus epithelial cells; PMEF: primary mouse embryo fibroblasts; SOD: superoxide dismutase; MDA: malondialdehyde.

Table 2.3 Comparison of in vitro oxidative stress results from studies with ENMs using two or more different readout systems.

The induction of oxidative stress and resulting inflammation is thought to be a plausible mechanism by which ENMs may induce toxicity, similar to fine and ultrafine particulate matter (Li and Huang 2008; Nel et al. 2006). ENMs may induce oxidative stress via a number of pathways. For example, generation of $\mathrm{O}_{2}{ }^{\circ}$ and $\mathrm{OH}^{\circ}$ radicals may result from the formation of electron hole pairs by photoactivation of $\mathrm{TiO}_{2}$ or from an electron jumping from the conduction band of semiconductor ENMs. In addition, dissolution of ENMs releasing metal ions and the presence of transition metals such as $\mathrm{Fe}, \mathrm{Ni}, \mathrm{Cu}, \mathrm{Co}$ and $\mathrm{Cr}$ on the ENM surface can generate $\mathrm{O}_{2}{ }^{\circ}$ via the Fenton reaction. Finally, even inert ENMs may give rise to ROS production by lodging in mitochondria and perturbing their function (Li and Huang 2008).

Many in vitro studies with ENMs have therefore focused on assays measuring markers of oxidative stress and inflammation. For oxidative stress, the two most commonly used assays in nanotoxicology research are measurement of intracellular ROS generation and reduced glutathione (GSH). ROS is mostly measured by means of a fluorometric assay based on intracellular oxidation of 2,7-dichlorofluoroscein diacetate $\left(\mathrm{H}_{2} \mathrm{DCF}-\mathrm{DA}\right)$, while GSH is measured with assays based on the production of a fluorescent or colored dye upon reaction with GSH. The results of ROS and GSH assays correlated remarkably well (Carlson et al. 2008; Hussain et al. 2005; Park et al. 2008; Yang et al. 2009) (Table 2.3). 


\begin{tabular}{|c|c|c|c|}
\hline Reference & Nanomaterial & Readout system & Key findings \\
\hline $\begin{array}{l}\text { Carlson et al. } \\
(2008)\end{array}$ & $\mathrm{Ag}$ & $\begin{array}{l}\text { TNF- } \alpha \text {, MIP-2, IL- } \\
1 \beta \text {, IL- } 6 \text { in alveolar } \\
\text { macrophages }\end{array}$ & $\begin{array}{l}\text { Ag significantly increased TNF- } \alpha \text {, MIP-2 } \\
\text { and IL-1 } \beta \text {, but not IL- } 6 \text {. }\end{array}$ \\
\hline $\begin{array}{l}\text { Kang et al. } \\
(2008)\end{array}$ & $\mathrm{TiO}_{2}^{\mathrm{a}}$ & $\begin{array}{l}\text { TNF- } \alpha, \text { MIP-2 in } \\
\text { RAW } 264.7\end{array}$ & $\begin{array}{l}\text { Ultrafine } \mathrm{TiO}_{2} \text { significantly increased } \\
\text { both TNF- } \alpha \text { and MIP-2. Effects of fine } \\
\mathrm{TiO}_{2} \text { were less on both markers of } \\
\text { inflammation. }\end{array}$ \\
\hline $\begin{array}{l}\text { Sayes et al. } \\
(2007)\end{array}$ & $\begin{array}{l}\mathrm{Cl}, \mathrm{CS}^{\mathrm{b}}, \mathrm{SiO}_{2} \\
\mathrm{ZnO}^{\mathrm{a}}\end{array}$ & $\begin{array}{l}\text { TNF- } \alpha, \text { MIP-2, IL-6 } \\
\text { in L2, AM and co- } \\
\text { culture }\end{array}$ & $\begin{array}{l}\text { In co-cultures exposed to } \mathrm{Cl} \text { and } \mathrm{CS} \text {, } \\
\text { reasonable agreement was found } \\
\text { between the three markers. For other } \\
\text { nanomaterials and individual cell types, } \\
\text { results between markers varied widely. }\end{array}$ \\
\hline \multicolumn{4}{|c|}{$\begin{array}{l}{ }^{b} \text { The material used in this study was Min-U-Sil quartz, which technically is not a nanomaterial, } \\
\text { but fine sized crystalline silica. }\end{array}$} \\
\hline \multicolumn{4}{|c|}{$\begin{array}{l}\text { Ag: silver; } \mathrm{TiO}_{2} \text { : titanium dioxide; } \mathrm{Cl} \text { : carbonyl iron; } \mathrm{CS} \text { : crystalline silica; } \mathrm{SiO}_{2} \text { : amorphous silica; } \\
\mathrm{ZnO} \text { : zinc oxide; TNF- } \alpha \text { : tumor necrosis factor } \alpha \text {; MIP-2: Macrophage Inflammatory Protein-2; } \\
\text { IL-1 } \beta \text { : interleukin 1- } \beta \text {; IL-6: interleukin 6; RAW 264.7: mouse peritoneal macrophage; L2: rat lung } \\
\text { epithelial cell; AM: rat primary alveolar macrophage }\end{array}$} \\
\hline
\end{tabular}

Table 2.4 Comparison of in vitro inflammation results from studies with ENMs using two or more different readout systems.

In vitro markers of inflammation mostly encountered in nanotoxicology research are tumor necrosis factor $\alpha$ (TNF- $\alpha$ ), macrophage inhibitory protein (MIP-2) and interleukin 6 (IL-6), mostly measured by enzyme linked immunosorbent assays (ELISA). Reasonable agreement in results of multiple inflammation markers have been found (Carlson et al. 2008; Kang et al. 2008), although wide discrepancies have also been reported (Sayes et al. 2007) (Table 2.4). It is unknown which type of cytokines are most relevant to investigate after cell exposure to ENMs, although the cell type used probably plays an important role. In general, the reasons for the selection of the cytokine types included in the studies are not reported.

\subsubsection{Genotoxicity readout systems}

The potential ability of many ENMs to transport across the cell membrane and even enter the nucleus in combination with findings of oxidative stress induction has led to the concern that exposure to ENMs may cause (oxidative) DNA damage. To investigate this, studies with ENMs have mostly utilized the micronucleus assay and the Single Cell Gel Electrophoresis assay, often referred to as the comet assay. The comet assay detects DNA double- and single strand breaks, alkali-labile sites and delayed repair-site detection in 
individual eukaryotic cells. It is a commonly used assay for regular chemicals, although no validated assay protocol guideline is available. In addition to damage to chromosomes, the micronucleus test also detects damage to the mitotic apparatus of cells. The development of a test guideline by the OECD for the in vitro micronucleus test is ongoing. Of the two assays, the comet assay probably detects most genetic damage, as it also picks up repairable defects which may disappear during the mitotic cycle included in the micronucleus assay.

Despite the differences in sensitivity, results from the few studies using both the micronucleus and the comet assay correlate reasonably well when the same ENMs are studied in the same cell type (Colognato et al. 2008; Kisin et al. 2007; Wang et al. 2007) (Table 2.5). A third commonly used genotoxicity assay for regular chemicals is the Ames test, which detects genetic point mutations by base substitutions or frame shifts in bacterial cells only. This test has not been used often for ENMs, and may not be adequate because many ENMs may be unable to transport across prokaryotic cell membranes. For example, genotoxicity of SWCNTs was detected by both the comet and micronucleus assay, while no mutations were found in the Ames test (Kisin et al. 2007).

In summary, for the evaluation of oxidative stress, inflammation and genotoxic potential of ENMs there appears to be a general agreement between different readout systems. In contrast, large discrepancies have often been reported for cytotoxicity readout systems. For all toxicity endpoints, generation of dose-response data that are uniform across different readout systems is problematic, as can be anticipated due to differences in sensitivity between assays.

\begin{tabular}{|c|c|c|c|}
\hline Reference & Nanomaterial & Readout system & Key findings \\
\hline $\begin{array}{l}\text { Colognato et } \\
\text { al. (2008) }\end{array}$ & Co & $\begin{array}{l}\text { Micronucleus, comet } \\
\text { in PBL }\end{array}$ & $\begin{array}{l}\text { Both readout systems detected } \\
\text { genotoxicity of Co at similar } \\
\text { concentrations. }\end{array}$ \\
\hline $\begin{array}{l}\text { Kisin et al. } \\
(2007)\end{array}$ & SWCNT & $\begin{array}{l}\text { Micronucleus, } \\
\text { comet in V79, } \\
\text { Ames in Salmonella } \\
\text { typhimurium }\end{array}$ & $\begin{array}{l}\text { Genotoxicity of SWCNT was } \\
\text { detected with comet and } \\
\text { micronucleus assay, although the } \\
\text { latter was not significant. Ames test } \\
\text { was negative. }\end{array}$ \\
\hline $\begin{array}{l}\text { Wang et al. } \\
\text { (2007) }\end{array}$ & $\mathrm{TiO}_{2}$ & $\begin{array}{l}\text { Micronucleus, comet } \\
\text { and HPRT in WIL2-NS }\end{array}$ & $\begin{array}{l}\text { Genotoxicity of } \mathrm{TiO}_{2} \text { was detected } \\
\text { with all three readout systems, at } \\
\text { similar concentrations. }\end{array}$ \\
\hline
\end{tabular}

Co: cobalt; SWCNT: single walled carbon nanotube; $\mathrm{TiO}_{2}$ : titanium dioxide; $\mathrm{PBL}$ : human peripheral blood leukocyte; V79: Chinese hamster lung fibroblast; HPRT: hypoxanthine-guanine phosphoribosyl transferase gene mutation assay; WIL2-NS: human lymphoblastoid cell.

Table 2.5 Comparison of in vitro genotoxicity results from studies with ENMs using two or more different readout systems. 


\subsubsection{Effect of cell type choice on outcome of in vitro studies}

Logically, in vitro particulate matter research has focused mainly on lung epithelial cells and macrophages. Physicochemical characteristics and the form in which humans are exposed to airborne nanoparticles determines to a great extent the location of deposition of the nanoparticles in the lung and the cell type that interacts with these nanoparticles (International Commission on Radiological Protection (ICRP) 1994; Yang et al. 2008). In fact, manipulating the dosage form of drug carrying ENMs is a major focus of research in the development of effective pulmonary drug delivery vehicles, for both local and systemic drug targets (Yang et al. 2008). Recent studies provide evidence that the response of the lung to particles may be an effect of the combined responses of various cell types (Alfaro-Moreno et al. 2008; Herseth et al. 2008). For example, a co-culture of lung epithelial cells, macrophages and mast cells exposed to particulate matter released more cytokines than the sum of the single cultures (Alfaro-Moreno et al. 2008). For exposure to ENMs via inhalation, the use of co-cultures of macrophages and other lung cells may better reflect the in vivo response. Nevertheless, one study comparing in vivo inhalation toxicity of various ENMs with in vitro results in a co-culture of macrophages and lung epithelial cells showed little correlation (Sayes et al. 2007).

Due to the wide variation in nanotechnology applications, beside inhalation practically all existing routes of exposure could be relevant for engineered ENMs, as is the case for regular chemicals. As a consequence, many toxicity endpoints and an even greater number of cell types or tissues may need to be considered in safety evaluations of ENMs. The choice of the most relevant cell type for in vitro toxicity studies on ENMs is therefore a difficult one. This is clearly reflected by the myriad of cell types that have been used in nanotoxicology research.

\subsubsection{Cell types and uptake, localization and removal of ENMs}

In vivo studies remarkably demonstrate that the cell types interacting with ENMs depends on the route of entry. In studies where ENMs were administered intravenously, intraperitoneally or intra-abdominally, ENMs were mainly taken up by the mononuclear phagocyte system which includes macrophages in liver, lung, spleen and bone marrow (Chen et al. 2003; Fischer and Chan 2007; Hamoir et al. 2003; Sadauskas et al. 2007). In fact, avoidance of rapid clearance of drug carrying ENMs by phagocytic cells is a main aim in the development of novel therapeutic agents (Li and Huang 2008).

\begin{tabular}{|c|c|c|c|}
\hline Reference & Nanomaterial & Cell types & Key findings \\
\hline $\begin{array}{l}\text { Chung et al. } \\
\text { (2007) }\end{array}$ & $\begin{array}{l}\text { MSN with } \\
\text { various surface } \\
\text { charges }\end{array}$ & 3T3-L1, hMSC & $\begin{array}{l}\text { MSN was efficiently taken up by } \\
\text { both cell types. Uptake of MSN } \\
\text { with high positive surface charge } \\
\text { occurred via clathrin dependent } \\
\text { endocytosis in } 3 T 3-\text { L1, but via an } \\
\text { unknown, clathrin independent } \\
\text { pathway in hMSC. }\end{array}$ \\
\hline
\end{tabular}




\begin{tabular}{|c|c|c|c|}
\hline Reference & Nanomaterial & Cell types & Key findings \\
\hline $\begin{array}{l}\text { Diaz et al. } \\
(2008)\end{array}$ & $\begin{array}{l}\text { Fe graphite, } \\
\text { magnetite } \mathrm{SiO}_{2} \text {, } \\
\text { (PEG-ylated) } \\
\mathrm{SiO}_{2}, \text { magnetite } \\
\mathrm{AlSiO}_{2}\end{array}$ & $\begin{array}{l}\text { Human monocytes, } \\
\text { lymphocytes, } \\
\text { erythrocytes, } \\
\text { U937, PC3, mouse } \\
\text { primary peritoneal } \\
\text { macrophages, Jurkat, } \\
\text { HMY }\end{array}$ & $\begin{array}{l}\text { Rapid uptake of nanomaterials in } \\
\text { human monocytes, PC } 3 \text { and mouse } \\
\text { macrophages was observed, but } \\
\text { human lymphocytes, erythrocytes, } \\
\text { Jurkat and HMY were less efficient. } \\
\text { U937 did not appear to take up } \\
\text { ENMs at all. }\end{array}$ \\
\hline Jin et al. (2007) & $\begin{array}{l}\text { Luminescent } \\
\mathrm{SiO}_{2}\end{array}$ & $\begin{array}{l}\text { A549, rat primary } \\
\text { alveolar macrophages }\end{array}$ & $\begin{array}{l}\text { Compared to the A549 cells, } \\
\text { ENMs penetrated rat alveolar } \\
\text { macrophages much faster. }\end{array}$ \\
\hline $\begin{array}{l}\text { Lorenz et al. } \\
(2006)\end{array}$ & $\begin{array}{l}\text { Polymeric } \\
\text { particles with } \\
\text { various surface } \\
\text { charges }\end{array}$ & $\begin{array}{l}\text { HeLa, hMSC, Jurkat, } \\
\text { KG1a }\end{array}$ & $\begin{array}{l}\text { Uptake of ENMs was related to } \\
\text { surface charge in HeLa cells, but not } \\
\text { in hMSC cells. ENMs were located } \\
\text { in intracellular compartments } \\
\text { resembling endosomes, whereas for } \\
\text { Jurkat and KG1a, ENMs appeared to } \\
\text { be located mostly on the outer cell } \\
\text { membrane. }\end{array}$ \\
\hline
\end{tabular}

MSN: mesoporous silica nanoparticles; $\mathrm{SiO}_{2}$ : silica; PEG: polyethylene-glycol; $\mathrm{AlSiO}_{2}$ : aluminum silica; 3T3-L1: mouse embryonic fibroblast; hMSC: human mesenchymal stem cell; U937: human myeloid-monocytic cell; PC3: human prostatic cell; Jurkat: human T cell; HMY: human B cell; A549: human lung epithelial cell; HeLa: human cervical cancer cell; KG1a: CD34+ hematopoetic stem cell

Table 2.6 Comparison of in vitro studies on cell uptake, localization and removal of ENMs using two or more cell types.

Airway and alveolar macrophages are highly effective in the clearance of micrometer-sized particles from the lung. In contrast, inhalation studies have shown that lung macrophages were rather inefficient in the uptake and clearance of ENMs from the alveolar region (Geiser et al. 2008; Semmler-Behnke et al. 2008; Yang et al. 2008). For example, analysis of BALF from rats obtained 24 hours after inhalation of $\mathrm{TiO}_{2}$ nanoparticles of $20 \mathrm{~nm}$ demonstrated uptake of only 0.06 to $0.12 \%$ of the particles by lung-surface macrophages (Geiser et al. 2008). Inhaled ENMs that are not cleared by macrophages may interact with other cells of the lung alveolar lining such as lung epithelial cells and dendritic cells (Blank et al. 2008). Dendritic cells are involved in the adaptive immune response of the respiratory tract and have been demonstrated to play a role in allergy-stimulating effects of particulate matter (de Haar et al. 2008). ENMs in the alveolar region may also be translocated to secondary organs, where they are now available to interact with many other cell types (Yang et al. 2008).

In in vivo studies where ENMs were administered intravenously or intra-abdominally 
uptake of ENMs by various cell types other than macrophages has also been demonstrated. Fluorescent labeled $\mathrm{SiO}_{2}$ ENMs were taken up by splenic cordic cells, neuronal cells of the brain, pulmonary alveolar cells, hepatocytes, epithelial cells of the small intestine and in testicle, gland and interstitial cells of the testis (Chen et al. 2003).

In vitro studies have also demonstrated uptake of ENMs by various cell types, including mouse macrophages, mouse embryonic fibroblasts and human mesenchymal stem cells (Chen et al. 2003; Chung et al. 2007; Diaz et al. 2008; Jin et al. 2007; Lorenz et al. 2006), but large differences in uptake and subcellular localization were observed (Table 2.6). For example, mouse macrophages were very efficient in taking up ENMs of various compositions. More surprisingly, human prostatic cells were almost as efficient, while human myeloidmonocytic cells (U937) did not show any internalization of ENMs (Diaz et al. 2008). For some, but not all cell types, the uptake efficiency appears to be related to the surface charge of the ENM (Chung et al. 2007; Lorenz et al. 2006) (Table 2.6). Even if uptake of ENMs by certain cell types is relatively low, little research has been published on the removal of ENMs by cells. Information on the persistence of ENMs in cells is essential in risk assessment, as accumulation in cells may potentially lead to toxic effects in the long term.

\subsubsection{Effect of cell type choice on outcome of in vitro cytotoxicity studies}

With the existing differences in uptake, intracellular localization and removal of ENMs between cell types it can be expected that the extent of toxicity observed for a particular ENM varies from one cell type to another. Indeed, studies comparing cytotoxicity of various ENMs between macrophages and other cell types found that the macrophage cell line was more sensitive to the cytotoxic effects of ENMs than other cell types (Jin et al. 2007; Lison et al. 2008; Yamamoto et al. 2004) (Table 2.7).

\begin{tabular}{|c|c|c|c|}
\hline Reference & Nanomaterial & Cell type & Key findings \\
\hline $\begin{array}{l}\text { Ahamed et al. } \\
(2008)\end{array}$ & $\mathrm{Ag}$ & MES, MEF & $\begin{array}{l}\text { Similar sensitivity to cytotoxic } \\
\text { effects of ENMs }\end{array}$ \\
\hline $\begin{array}{l}\text { Brunner et al. } \\
(2006)\end{array}$ & $\begin{array}{l}\text { Asbestos, } \mathrm{SiO}_{2}, \\
\mathrm{ZnO}, \mathrm{Fe}_{2} \mathrm{O}_{3} \\
\mathrm{Ca}_{3}\left(\mathrm{PO}_{4}\right)_{2}, \mathrm{TiO}_{2}, \\
\mathrm{CeO}_{2}, \mathrm{ZrO}_{2}\end{array}$ & MSTO and 3 T3 cells & $\begin{array}{l}\text { In general, MSTO cells were } \\
\text { more sensitive to cytotoxic } \\
\text { effects of ENMs, especially of } \\
\text { asbestos and } \mathrm{Fe}_{2} \mathrm{O}_{3} \text {. }\end{array}$ \\
\hline $\begin{array}{l}\text { Chang et al. } \\
(2007)\end{array}$ & $\begin{array}{l}\mathrm{SiO}_{2}, \mathrm{SiO}_{2-}^{-} \\
\text {chitosan }\end{array}$ & $\begin{array}{l}\text { WS1, CCD-996sk, MRC-5, } \\
\text { A549, MKN-28, HT-29 }\end{array}$ & $\begin{array}{l}\text { Cancer cell lines (A549, HT-29, } \\
\text { and MKN-28) had a higher cell } \\
\text { viability than lung and skin } \\
\text { fibroblast cell lines (MRC-5, } \\
\text { WS1, and CCD-966sk) when } \\
\text { incubated with ENMs. }\end{array}$ \\
\hline
\end{tabular}




\begin{tabular}{|c|c|c|c|}
\hline Reference & Nanomaterial & Cell type & Key findings \\
\hline $\begin{array}{l}\text { Diaz et al., } \\
\text { (2008) }\end{array}$ & $\begin{array}{l}\text { Fe graphite, } \\
\text { magnetite } \mathrm{SiO}_{2}, \\
\text { (PEG-ylated) } \\
\mathrm{SiO}_{2}, \text { magnetite } \\
\mathrm{AlSiO}_{2}\end{array}$ & $\begin{array}{l}\text { Human monocytes, } \\
\text { lymphocytes, } \\
\text { erythrocytes, U937, } \\
\text { PC3, mouse primary } \\
\text { peritoneal macrophages, } \\
\text { Jurkat, HMY }\end{array}$ & $\begin{array}{l}\text { While } \mathrm{HMY} \text { cells were most } \\
\text { sensitive to cytotoxic effects of } \\
\text { Fe graphite, magnetite } \mathrm{SiO}_{2} \text {, and } \\
\mathrm{SiO}_{2} \text {, Jurkat cells appeared more } \\
\text { sensitive to magnetite } \mathrm{AlSiO}_{2} \text {. }\end{array}$ \\
\hline Jin et al. (2007) & $\begin{array}{l}\text { Luminescent } \\
\mathrm{SiO}_{2}\end{array}$ & A549, MHS & $\begin{array}{l}\text { Compared to A549, luminescent } \\
\mathrm{SiO}_{2} \text { was more cytotoxic to MHS. }\end{array}$ \\
\hline $\begin{array}{l}\text { Lison et al. } \\
\text { (2008) }\end{array}$ & $\mathrm{SiO}_{2}$ & A549, ЕАНY926, J774 & $\begin{array}{l}\text { J774 was most sensitive to } \\
\text { cytotoxic effects of } \mathrm{SiO}_{2} \\
\text { EAHY926 was least sensitive. }\end{array}$ \\
\hline $\begin{array}{l}\text { Sayes et al. } \\
(2007)\end{array}$ & $\begin{array}{l}\mathrm{Cl}, \mathrm{CS}^{\mathrm{a}}, \mathrm{SiO}_{2} \\
\mathrm{ZnO}^{\mathrm{b}}\end{array}$ & L2, AM and co-culture & $\begin{array}{l}\text { AM appeared to be resistant } \\
\text { to cytotoxicity of ENMs as } \\
\text { measured by LDH, in contrast to } \\
\text { L2 and co-culture. }\end{array}$ \\
\hline $\begin{array}{l}\text { Yamamoto et } \\
\text { al. (2004) }\end{array}$ & $\begin{array}{l}\mathrm{TiO}_{2} \\
\mathrm{Al}_{2} \mathrm{O}_{3}, \mathrm{ZrO}_{2} \\
\mathrm{Si}_{3} \mathrm{~N}_{4}, \mathrm{SiC}\end{array}$ & J774A.1, L929 & $\begin{array}{l}\mathrm{EC}_{50} \text { values for J774A.1 tend to } \\
\text { be smaller than those for } \mathrm{L} 929 \text {, } \\
\text { indicating that J774A.1 is more } \\
\text { sensitive. }\end{array}$ \\
\hline
\end{tabular}

a The material used in this study was Min-U-Sil quartz, which technically is not a nanomaterial, but fine sized crystalline silica.

${ }^{\mathrm{b}}$ Both nano- and fine sized zinc oxide particles were used in this study.

$\mathrm{Ag}$ : silver; $\mathrm{SiO}_{2}$ : silica; $\mathrm{ZnO}$ : zinc oxide; $\mathrm{Fe}_{2} \mathrm{O}_{3}$ : iron oxide; $\mathrm{Ca}_{3}\left(\mathrm{PO}_{4}\right)_{2}$ : tricalcium phosphate, $\mathrm{TiO}_{2}$ : titanium dioxide, $\mathrm{CeO}_{2}$ : ceria; $\mathrm{ZrO}_{2}$ : zirconia; Fe: iron; PEG: poly-ethylene glycol; $\mathrm{AlSiO}_{2}$ : aluminum silica; $\mathrm{Cl}$ : carbonyl iron; $\mathrm{CS}$ : crystalline silica; $\mathrm{Al}_{2} \mathrm{O}_{3}$ : aluminum oxide; $\mathrm{Si}_{3} \mathrm{~N}_{4}$ : silicon nitride; $\mathrm{SiC}$ : silicon carbide; MES: mouse embryonic stem cell; MEF: mouse embryonic fibroblast; MSTO: human mesothelioma cell; 3T3: rodent fibroblast cell; WS1: human skin fibroblast; CCD-998sk: human skin fibroblast; MRC-5: human lung fibroblast; A549: human lung epithelial cell; MKN28: human gastric epithelial cell; HT-29: human colon epithelial cell; U937: human myeloidmonocytic cell; PC3: human prostatic cell; Jurkat: human T cell; HMY: human B cell; MHS: alveolar macrophage; EAHY926: human endothelium cell; J774: mouse monocyte macrophage; L2: rat lung epithelial cell; AM: rat alveolar macrophage; L929: mouse embryonic fibroblast; $\mathrm{EC}_{50}: 50 \%$ effective concentration compared to control.

Table 2.7 Comparison of cytotoxicity results from studies with ENMs using two or more cell types.

In contrast, Sayes et al. demonstrated that rat alveolar macrophages were less sensitive to the toxic effects of various ENMs than L2 lung epithelial cells or a co-culture of the two cells (Sayes et al. 2007). Moreover, one study demonstrated that ENM cytotoxicity did not correlate well with the extent of ENM uptake in the cell. While human prostatic (PC3) cells 
were very efficient in ENM uptake, cytotoxicity in this cell line to various ENMs was not higher than that found in human myeloid-monocytic U937 cells, which did not show any internalization of ENMs (Diaz et al. 2008).

ENM toxicity may also be targeted on the specific cellular function of a particular cell type. However, as discussed before, most published in vitro studies have focused on general cytotoxicity endpoints only, with readout systems based on DNA content, cell membrane integrity and metabolic activity. Still, even when using these general cytotoxicity assays, cell-specific properties such as proliferation rates and metabolic activities may lead to different outcomes between cell types (Table 2.7). It has been suggested that cytotoxicity in three different normal fibroblast cell lines to $\mathrm{SiO}_{2}$ ENMs was higher than cytotoxicity found in three epithelial carcinoma cell lines due to the longer doubling times of the fibroblasts (Chang et al. 2007). In contrast to these findings, 3T3-L1 fibroblasts were much less sensitive to the cytotoxic effects of ferric oxide $\left(\mathrm{Fe}_{2} \mathrm{O}_{3}\right)$ ENMs than faster proliferating mesothelioma cells (Brunner et al. 2006). Seemingly, the factors involved in the sensitivity of cell types to the cytotoxic effects of ENMs have not all been elucidated. This complicates the choice of an appropriate cell type for in vitro studies in risk assessment procedures.

\subsubsection{Effect of cell type choice on outcome of oxidative stress and inflammation studies}

While there is considerable agreement in results of different readout systems for oxidative stress, large differences are found when multiple cell types are used. A factor to consider in the selection of cell type for studying the induction of oxidative stress by ENMs is that not all cell types may be equally equipped to handle oxidative stress induced by ENMs. For example, high levels of reactive oxygen species were produced by murine macrophages, but not by human peripheral blood cells upon exposure to the same panel of ENMs (Diaz et al. 2008). Production of reactive oxygen species by human carcinoma cell lines varied with the origin of the cell line (Diaz et al. 2008). With regard to inflammation markers, different cell types may induce different levels of cytokines upon the same exposure. For example, production of IL-8 increased in human lung epithelial cells (A549) exposed to titanium dioxide ENMs, but not in human dermal fibroblasts (Sayes et al. 2006).

\subsubsection{Effect of cell type choice on outcome of genotoxicity studies}

Only two recent studies were found that compared genotoxicity of ENMs in more than one different cell type using a single readout system. Using the micronucleus test, an increase in genotoxicity was found in both human breast carcinoma cells (MCF-7) and rat lung epithelial cells (RLE) exposed to multi-walled carbon nanotubes, although the dose dependency in the MCF-7 was not clear (Muller et al. 2008). Exposure to polysaccharide coated silver ENMs induced expression of phosphorylated p53 in mouse embryonic stem cells, but not in mouse embryonic fibroblasts. Apoptosis was induced in both cell types, although embryonic stem cells appeared to be more sensitive (Ahamed et al. 2008). Results from these two studies imply that cell types may differ in their sensitivity to the 
genotoxic effects caused by ENMs. However, to gain more insight in cell specific responses with regard to genotoxicity, more data from experiments including multiple cell types need to become available.

In general, for all toxicity endpoints, the choice of cell type appears to be a major contributing factor underlying the differences observed in toxic responses to ENMs. These differences are likely in part due to different uptake and removal of ENMs by cells, but could also be related to the inherently different 'equipment' of various cell types to deal with ENMs, such as antioxidant levels or DNA repair mechanisms.

\subsubsection{Effect of exposure duration on outcome of in vitro studies}

Standard protocols with recommendations for exposure durations are not available for every toxicity assay in every cell type, and this is reflected by the variety of exposure durations encountered in nanotoxicology research.

\subsubsection{Effect of exposure duration on outcome of in vitro cytotoxicity studies}

In its guidance documents for cytotoxicity studies, the ICCVAM states that chemical exposure should last at least one full cell cycle (ICCVAM 2001). Exposure durations encountered in cytotoxicity studies with ENMs, carried out in many different cell lines, range from 1 hour to 6 days. In most studies, observed cytotoxicity increased with exposure duration up to 96 hours (Ahamed et al. 2008; Diaz et al. 2008; Park et al. 2008; Sayes et al. 2006; Simon-Deckers et al. 2008; Wang et al. 2007) (Table 8). However, some studies reported a decrease in cytotoxicity when incubation periods were increased to 48 hours or longer (Brunner et al. 2006; Diaz et al. 2008; Sayes et al. 2007). It has been suggested that the decrease in cytotoxicity was due to sealing or detoxification of particles in cellular compartments (Brunner et al. 2006).

\subsubsection{Effect of exposure duration on outcome of in vitro oxidative stress and inflammation studies}

Most studies investigating cellular oxidative stress response to ENMs have used a single exposure duration of 4 or 24 hours (Carlson et al. 2008; Hussain et al. 2005; Karlsson et al. 2008; Limbach et al. 2007; Park et al. 2008; Yang et al. 2009). Studies measuring reactive oxygen species after multiple exposure durations reveal that increased levels of ROS after 4 hours of exposure or less may decline toward levels of untreated control cells when the exposure duration is increased, possibly due to an adaptive antioxidant response of the cell (Diaz et al. 2008; Kang et al. 2008). Production of inflammation markers is measured mostly after approximately 24 hours (Duffin et al. 2007; Sayes et al. 2007; Sayes et al. 2006; Waldman et al. 2007), and no studies were found that included more than one exposure duration. It is therefore unknown whether the induction of inflammation markers such as cytokines after ENM exposure changes with longer exposure durations. 


\subsubsection{Effect of exposure duration on outcome of in vitro genotoxicity studies}

The OECD draft guideline for the in vitro micronucleus assay states that most aneugens and clastogens will be detected by a short term exposure duration of 3 to 6 hours, followed by a sampling time approximately 1.5 normal cell cycles from the beginning of the exposure. Exposure durations in genotoxicity studies with ENMs vary from 3 to 72 hours. In two studies reporting genotoxicity after multiple exposure durations, the effects were more profound after longer exposure durations (Ahamed et al. 2008; Kisin et al. 2007).

In summary, exposure duration plays an important role in the results of toxicity assays in vitro. Noteworthy, a longer exposure duration does not necessarily imply increased toxicity. After initial toxicity, a response similar to that of untreated cells after longer exposure durations has been observed in both cytotoxicity and oxidative stress studies, possibly due to an adaptive response of the cells. For many readout systems, it is important to consider the doubling time of the cell type when deciding upon the duration of the exposure period and the sampling time. For example, the formation of micronuclei after mitosis may go undetected when short sampling times are used in slow proliferating cells. In addition, ENMs may themselves affect cell doubling times, which needs to be taken into account in the interpretation of assay results. For example, measurement of LDH leaking out of damaged cells may be underestimated if the ENM also inhibits cell proliferation, leading to a decrease in total LDH available to leak out of cells. Measurement of LDH after ENM exposure therefore always needs to be corrected for total amount of LDH available in the ENM exposed cells.

Long term in vitro studies, i.e. with exposure durations over 72 hours, are difficult to carry out, especially when cells with short doubling times are used. The cells may exceed $100 \%$ confluence in the experimental wells and cell culture medium may become depleted. Seeding cells at lower initial cell concentrations may help resolve this, although it needs to be realized that cell concentration may in itself affect cell viability (Diaz et al. 2008).

\subsection{DOSE RESPONSE ANALYSIS OF IN VITRO RESULTS}

As discussed before, the use of multiple readout systems for the same toxicity endpoint may in many cases provide corresponding information on the absence or presence of a toxic response to ENMs. However, for all toxicity endpoints, the concentrations at which the toxic response is observed mostly vary too widely between readout systems to generate unequivocal dose response data.

An ongoing point of discussion is the most appropriate dose metric i.e. the unit of expressing the concentration of ENMs in in vitro assays. Although in most studies, concentrations are expressed in mass per volume, some have claimed that the number or volume of particles determines cytotoxicity of ENMs (Di Pasqua et al. 2008; Yamamoto et 
al. 2004). There are also several observations that the induction of inflammation markers by so called low-toxicity and low-solubility (LTLS) ENMs is related to surface area rather than mass, volume or number of ENMs (Duffin et al. 2007; Monteiller et al. 2007). For example, Duffin et al. have demonstrated a linear relationship between surface area dose and production of IL-8 protein (a marker of inflammation) by A549 cells for a panel of engineered nanoparticles of different sizes. The authors therefore suggested that for the purpose of benchmarking particles for regulatory purposes, data should be expressed as ENM specific surface activity (Duffin et al. 2007). Others have taken this approach one step further in suggesting the expression of in vitro concentrations as surface area dose per unit cell culture surface area.(Donaldson et al. 2008).

The use of the dose metric surface area may have an important advantage for regulatory purposes. It can be anticipated that there may be various issues regarding the introduction and enforcement of regulations specific for ENMs, currently defined as materials with at least one dimension below $100 \mathrm{~nm}$. The primary and especially hydro- or aerodynamic size distributions of ENMs may be quite broad, and it is unclear whether the cut-off dimension of $100 \mathrm{~nm}$ should be based on mean, median or other measures of size, or even the $5 \%$ lower end of the relevant size distribution. Therefore, it has been suggested that the current definition of ENMs based on physical size should be extended by the addition of a limit of the specific surface area, i.e. the surface area per mass (SCENIHR 2009).

Regardless whether concentrations are expressed as surface area or mass, there has been some discussion whether the nominal concentration is proportionate to the actual dose delivered to the cells for every ENM. In published in vitro studies with ENMs, the toxicity results are generally represented as nominal concentrations of the ENMs in cell culture medium. However, Teeguarden et al. (2007) suggested that the cellular dose of ENMs depends on gravitational settling and diffusion of the ENMs in suspension. At similar nominal concentrations, the cellular dose of one ENM may be much smaller than another, depending on size, density, and surface physicochemistry of the ENMs. Reliance on nominal concentration may therefore lead to incorrect conclusions regarding comparative toxicity of the ENMs (Teeguarden et al. 2007). For example, when nominal concentrations of a study on silver ENMs by Hussain et al. (2005) were adjusted for gravitational settling and diffusional transport, the difference in toxic potencies between different sized ENMs appeared less obvious (Teeguarden et al. 2007). In contrast, Lison et al. (2008) postulated that the presence of convection forces in suspensions will cause the majority of ENMs in the suspension to interact with cells and that these forces play a more important role than gravitational settling and diffusion behavior.

Lison et al. also reported that for a fixed concentration, the toxic response of various cell lines to $\mathrm{SiO}_{2}$ ENMs increased with dispersion volume (Lison et al. 2008). In other words, the response of ENMs in in vitro studies depended on total mass, number and surface area of ENMs administered to the cells. This complicates comparison of results between studies that have used cell culture dishes with different exposure volumes, for 
example 24- versus 96-well plates. In addition, the results indicate that the determination of for example the concentration at which $50 \%$ of the cells are affected by the ENM $\left(E_{50}\right.$ ) depends on the volume of the ENM dispersion used for the exposure.

Apparently, the factors determining the actual dose of ENMs delivered to cells in in vitro systems are not entirely elucidated. Even less is known about how to extrapolate from nominal concentration in vitro to the actual dose at target organs in vivo, as will be discussed later. Study reports need to specify the volume of ENM dispersion used for the exposure and include all necessary information to be able to convert between different dose metrics.

\subsection{ARTIFACTS IN IN VITRO TOXICITY ASSAYS WITH ENMS}

The in vitro test methods described above have been established for hazard characterization of chemicals, but their compatibility for ENMs may be limited. A now well known example of poor compatibility is the interaction of single walled carbon nanotubes with the substrate of the MTT assay, leading to a false positive result of reduced cell viability (Worle-Knirsch et al. 2006). A comprehensive overview of less well known limitations and challenges of in vitro toxicity assays in general and for ENMs in particular was recently published (Kroll et al. 2008). These include, but are not limited to, the interference of metal ions possibly released from certain ENMs, $\mathrm{pH}$ dependency and the reduced absorbance or fluorescence signal in various assays such as the MTT and LDH assay.

Furthermore, the adsorptive properties of ENMs may lead to artifacts due to direct interactions of the particles with assay substrates or cytokines (Monteiro-Riviere et al. 2009; Veranth et al. 2007), or more indirectly due to depleting the cell culture medium of essential nutrients and growth factors (Casey et al. 2008; Guo et al. 2008). These artifacts have been mostly demonstrated for carbonaceous ENMs. While the depletion of the cell culture medium of essential nutrients and growth factors may be an important effect of ENMs causing toxicity in in vitro studies, it is questionable whether this effect is relevant for the in vivo situation.

Reports of interferences of ENMs with the comet and micronucleus genotoxicity assays are lacking. However, the Ames test may not be reliable for detecting mutagenic activity of ENMs, as they may not be able to enter prokaryotic cells (Kisin et al. 2007).

Some in vitro toxicity assays may not be compatible with the cell type under consideration. To ensure that the cell type, readout system, incubation time and other protocol choices are adequate, a positive control should always be included in each experiment. Where available, the positive control should be in particulate form. For example, DQ12 quartz is known for its highly reactive surface and may serve as a positive control in in vitro oxidative stress and inflammation studies. 
A potentially large artifact in the outcome of in vitro toxicity studies with ENMs arises from the presence of contaminants associated with ENMs, such as unknown surfactants, production residues or bacterial endotoxins. For example, the production of carbonaceous ENMs generally involves iron as a catalyst and the presence of iron in ENMs has been demonstrated to enhance oxidative stress and inflammation responses in macrophages (Kagan et al. 2006; Waldman et al. 2007). Commercially available ENM preparations may contain dispersants unspecified by the manufacturer, which may contribute to toxic effects observed (Murdock et al. 2008). In addition, most ENMs are not necessarily produced under sterile conditions and may at some point become contaminated with bacteria. Especially macrophages and dendritic cells become activated in the presence of endotoxins, possibly resulting in an increase in oxidative stress and production of inflammation markers such as cytokines. For example, phenotypic maturation and cytokine production of dendritic cells by gold ENMs was shown to be caused almost entirely by the presence of endotoxins in the ENM (Vallhov et al. 2006). Testing of ENMs on the presence of endotoxins is therefore of utmost importance, but results should be interpreted with caution as certain ENMs may interfere with the endotoxin test system (Schulze et al. 2008).

\subsection{CONCLUSIONS}

From both ethical and economical viewpoints there is no doubt that it would be desirable if the safety assessment of ENMs could be largely based on in vitro studies. However, from a scientific point of view, even for the purpose of screening ENMs for hazard identification or to investigate their mechanism of toxicity, there are numerous issues that need to be resolved before granting such an important role to in vitro studies within risk assessment procedures.

To begin with, relevant toxicity endpoints for ENMs need to be identified. Much can be learned from the vast scientific knowledge already obtained on inhalation toxicology of fine and ultra fine particulate matter. However, one should not forget that exposure routes other than inhalation may play an equally large or even larger role in the potential risks of ENMs. These exposure routes may result in a different systemic exposure and distribution of ENMs throughout the body compared to exposure via inhalation. Therefore, a safety evaluation of ENMs needs to consider many different toxicity endpoints relevant for different organs, depending on the application of the ENM (Nel et al. 2006; Oberdorster et al. 2005).

Much of the current in vitro research focuses on cytotoxicity, oxidative stress, inflammation and genotoxicity. Reproductive toxicity, immunotoxicity, sensitizing capacity and non-genotoxic carcinogenicity are potentially relevant toxicity endpoints that have gained relatively little attention, if any at all.

Once all relevant toxicity endpoints have been identified, appropriate in vitro assay 
protocols need to be developed which will need to be validated. The development of an appropriate in vitro assay protocol for ENMs starts with the choice of a suitable readout system, a relevant cell type and apt exposure durations. For regular chemicals, validated in vitro readout systems only exist for a limited number of toxicity endpoints such as skin corrosion. Other validated in vitro assays, for example genotoxicity assays, often need to be complemented with in vivo data for a complete evaluation of the toxicity endpoint. None of the validated in vitro assays for regular chemicals have formally been validated for use with ENMs.

Depending on the application of the ENM under consideration, many different cell types may be relevant to include in safety assessments, but it may not be feasible to include them all. For the purpose of prioritizing ENMs based on their hazardous properties, it would be favorable to select the most sensitive of the relevant cell types, but these may not always be available. Moreover, there appears to be no consensus on which cell properties or functions make one cell type more sensitive to the potential various toxic effects of ENMs than another. Differences in particle uptake and removal will obviously play a role, but specific cell functions will likely also be involved. Co-cultures may better reflect the in vivo exposure situation, although none of the currently described models can be used as a stand alone model, replacing the need for in vivo testing.

With regard to exposure duration, in vitro studies are only suitable to study effects of ENMs after relatively short exposure periods. However, many ENMs are specifically designed to be virtually undegradable and may accumulate in cells over time, making long term studies indispensable in risk assessment of these ENMs. A serious lack of information exists on the behavior of ENMs in cell culture medium even in short term studies. In general, effects of various ENM exposure and dispersion methods on the outcome of in vitro studies are largely unknown. This knowledge gap complicates the use of in vitro studies to identify potential hazards and mechanisms of action of ENMs, as certain dispersion protocols may pacify ENM surfaces, thereby concealing a potential effect.

It has been suggested that using more than one assay and cell type in a test battery will likely improve the predictive value of the test battery (Service 2008; Shaw et al. 2008). Nevertheless, it needs to be realized that including multiple assays and cell types will also introduce more variation in the results. In addition, the chance of finding toxicity of ENMs increases with the addition of more assays, and potentially leaves more room for false positives. Compatibility of the assays with the cell types needs to be confirmed. For example, a positive control in the experiments needs to be included to ensure the ability of a cell type to produce specific markers of toxicity. Interference of the ENM with the assays, such as scattering light in assays using absorbance as a readout system, or adsorbing assay reaction products to the ENM surface needs to be experimentally excluded. In addition, assay protocols need to include a check list of required ENM characterization to avoid false positives due to ENM contamination with, for example, toxic production residues and bacterial endotoxins. 
More importantly, results from in vitro studies mean nothing if not predictive for the in vivo situation. Studies comparing in vitro with in vivo toxicity data are limited to intratracheal instillation or inhalation studies. Two studies found reasonable concordance between the induction of interleukin-8 in A549 cells and number of polymorphonuclear neutrophils in bronchoalveolar fluid after inhalation or intratracheal instillation of various ENMs (Donaldson et al. 2008; Duffin et al. 2007). In contrast, a recent study demonstrated little correlation between the results of in vitro and in vivo measurements of cytotoxicity and inflammation after exposure to five different ENMs, despite the use of variations in the in vitro assay protocols such as cell types, measured end points and exposure duration (Sayes et al. 2007).

A major shortcoming of in vitro studies in general is that dose response data cannot readily be extrapolated to the in vivo situation. For ENMs in particular, there is a debate about the most appropriate dose metric to be used for in vitro studies. An important point of discussion in this debate is whether nominal concentrations are proportionate to the cellular dose for every ENM.

A further limitation of in vitro studies is the difficulty to study the biodistribution and clearance of ENMs in the body, which complicates the extrapolation from the in vitro cellular dose to the in vivo dose at target tissues. For example, the recruitment of inflammation cells in the lung cannot be simulated in vitro, at least not in a single immortalized cell culture (Sayes et al. 2007). In addition, the size of a ENM is one determining factor in the uptake and extrusion from different tissues, but for every tissue, the optimum size differs due to differences in pore sizes in the local endothelial wall (Li and Huang 2008). The presence of macrophages also determines the uptake of ENMs in for example liver, spleen and bone marrow (Li and Huang 2008). All in all, the biodistribution and clearance of ENMs in vivo appears too complicated to be fully captured in in vitro models, as it involves multiple tissues and cell types. Hence, even if validated in vitro toxicity assay protocols become available, they can merely be used for potential hazard identification and studying toxic mechanisms of action. Information on bioavailable concentrations of ENMs at target tissues will still need to be obtained by means of in vivo studies.

Ideally, by screening a wide variety of ENMs in various in vitro assays for many toxicity endpoints, one will eventually be able to determine which ENMs are more hazardous than others based on their physical and chemical properties. Not surprisingly however, by applying hierarchical clustering of biological activity data from over 50 different ENMs, Shaw et al. have demonstrated that biological activity of ENMs arises from the combined effects of many aspects of ENM composition and is therefore difficult to predict a priori (Shaw et al. 2008). It is becoming increasingly clear that more than one single physicochemical characteristic determines the toxicity of ENMs. Another perhaps more feasible approach would be to group ENMs according to their biological activity in a test battery, and compare this biological activity to that of a ENM that has been proven safe (Shaw et al. 2008). 
Either approach can only reliably be developed over time, when standard in vitro protocols are developed and validated and more data from studies using these protocols become available and are organized appropriately. In the meantime, as each ENM behaves differently and is accompanied by their own challenges, it may be worthwhile to invest in guidelines preventing common pitfalls encountered when using in vitro assays in nanotoxicology research.

\subsection{FUTURE PERSPECTIVES}

As the development of new nanotechnology applications continues to increase exponentially, the pressure to gain knowledge on the potential hazards of ENMs will rise. This will boost further development of validated in vitro assay protocols. At the same time, as more in vivo studies with ENMs become available, the values and limitations of in vitro studies as predictive tools in risk assessment of ENMs will come to light. Over the next 10 years, a balance will be sought between decreasing the use of in vivo studies by replacing them with in vitro studies and reliably predicting the risks of ENMs. 


\section{REFERENCES}

Ahamed M, Karns M, Goodson M, Rowe J, Hussain SM, Schlager JJ, Hong Y. 2008. DNA damage response to different surface chemistry of silver nanoparticles in mammalian cells. Toxicol Appl Pharmacol 233(3):404-10.

Aisaka Y, Kawaguchi R, Watanabe S, Ikeda M, Igisu H. 2008. Hemolysis caused by titanium dioxide particles. Inhal Toxicol 20(9):891-3.

Alfaro-Moreno E, Nawrot TS, Vanaudenaerde BM, Hoylaerts MF, Vanoirbeek JA, Nemery B, Hoet $\mathrm{PH}$. 2008. Co-cultures of multiple cell types mimic pulmonary cell communication in response to urban PM10. Eur Respir J 32(5):1184-94.

Berridge MV, Herst PM, Tan AS. 2005. Tetrazolium dyes as tools in cell biology: new insights into their cellular reduction. Biotechnol Annu Rev 11:127-52.

Bihari P, Vippola M, Schultes S, Praetner M, Khandoga AG, Reichel CA, Coester C, Tuomi T, Rehberg $\mathrm{M}$, Krombach F. 2008. Optimized dispersion of nanoparticles for biological in vitro and in vivo studies. Part Fibre Toxicol 5:14.

Blank F, Garnier Cv, Obregon C, Rothen-Rutishauser B, Gehr P, Nicod L. 2008. Role of dendritic cells in the lung: in vitro models, animal models and human studies. Expert Review of Respiratory Medicine 2(2):215-233.

Brunner TJ, Wick P, Manser P, Spohn P, Grass RN, Limbach LK, Bruinink A, Stark WJ. 2006. In vitro cytotoxicity of oxide nanoparticles: comparison to asbestos, silica, and the effect of particle solubility. Environ Sci Technol 40(14):4374-81.

Carlson C, Hussain SM, Schrand AM, Braydich-Stolle LK, Hess KL, Jones RL, Schlager JJ. 2008. Unique cellular interaction of silver nanoparticles: size-dependent generation of reactive oxygen species. J Phys Chem B 112(43):13608-19.

Casey A, Herzog E, Lyng FM, Byrne HJ, Chambers G, Davoren M. 2008. Single walled carbon nanotubes induce indirect cytotoxicity by medium depletion in A549 lung cells. Toxicol Lett 179(2):78-84.

Chang JS, Chang KL, Hwang DF, Kong ZL. 2007. In vitro cytotoxicitiy of silica nanoparticles at high concentrations strongly depends on the metabolic activity type of the cell line. Environ Sci Technol 41(6):2064-8.

Chen Y, Xue Z, Zheng D, Xia K, Zhao Y, Liu T, Long Z, Xia J. 2003. Sodium chloride modified silica nanoparticles as a non-viral vector with a high efficiency of DNA transfer into cells. Curr Gene Ther 3(3):273-9.

Chung TH, Wu SH, Yao M, Lu CW, Lin YS, Hung Y, Mou CY, Chen YC, Huang DM. 2007. The effect of surface charge on the uptake and biological function of mesoporous silica nanoparticles in 3T3L1 cells and human mesenchymal stem cells. Biomaterials 28(19):2959-66.

Colognato R, Bonelli A, Ponti J, Farina M, Bergamaschi E, Sabbioni E, Migliore L. 2008. Comparative genotoxicity of cobalt nanoparticles and ions on human peripheral leukocytes in vitro. Mutagenesis 23(5):377-82.

De Haar C, Kool M, Hassing I, Bol M, Lambrecht BN, Pieters R. 2008. Lung dendritic cells are stimulated by ultrafine particles and play a key role in particle adjuvant activity. J Allergy Clin Immunol 121(5):1246-54.

Di Pasqua AJ, Sharma KK, Shi YL, Toms BB, Ouellette W, Dabrowiak JC, Asefa T. 2008. Cytotoxicity of mesoporous silica nanomaterials. J Inorg Biochem 102(7):1416-23. 
Diaz B, Sanchez-Espinel C, Arruebo M, Faro J, de Miguel E, Magadan S, Yague C, Fernandez-Pacheco $\mathrm{R}$, Ibarra MR, Santamaria J et al. 2008. Assessing methods for blood cell cytotoxic responses to inorganic nanoparticles and nanoparticle aggregates. Small 4(11):2025-34.

Donaldson K, Borm PJ, Oberdorster G, Pinkerton KE, Stone V, Tran CL. 2008. Concordance between in vitro and in vivo dosimetry in the proinflammatory effects of low-toxicity, low-solubility particles: the key role of the proximal alveolar region. Inhal Toxicol 20(1):53-62.

Duffin R, Tran L, Brown D, Stone V, Donaldson K. 2007. Proinflammogenic effects of low-toxicity and metal nanoparticles in vivo and in vitro: highlighting the role of particle surface area and surface reactivity. Inhal Toxicol 19(10):849-56.

Dutta D, Sundaram SK, Teeguarden JG, Riley BJ, Fifield LS, Jacobs JM, Addleman SR, Kaysen GA, Moudgil BM, Weber TJ. 2007. Adsorbed proteins influence the biological activity and molecular targeting of nanomaterials. Toxicol Sci 100(1):303-15.

Fischer HC, Chan WC. 2007. Nanotoxicity: the growing need for in vivo study. Curr Opin Biotechnol 18(6):565-571.

Foucaud L, Wilson MR, Brown DM, Stone V. 2007. Measurement of reactive species production by nanoparticles prepared in biologically relevant media. Toxicol Lett 174(1-3):1-9.

French RA, Jacobson AR, Kim B, Isley SL, Penn RL, Baveye PC. 2009. Influence of ionic strength, $\mathrm{pH}$, and cation valence on aggregation kinetics of titanium dioxide nanoparticles. Environ Sci Technol 43(5):1354-9.

Geiser M, Casaulta M, Kupferschmid B, Schulz H, Semmler-Behnke M, Kreyling W. 2008. The role of macrophages in the clearance of inhaled ultrafine titanium dioxide particles. Am J Respir Cell Mol Biol 38(3):371-6.

Guo L, Von Dem Bussche A, Buechner M, Yan A, Kane AB, Hurt RH. 2008. Adsorption of essential micronutrients by carbon nanotubes and the implications for nanotoxicity testing. Small 4(6):721-7.

Hamoir J, Nemmar A, Halloy D, Wirth D, Vincke G, Vanderplasschen A, Nemery B, Gustin P. 2003.

Effect of polystyrene particles on lung microvascular permeability in isolated perfused rabbit lungs: role of size and surface properties. Toxicol Appl Pharmacol 190(3):278-85.

Herseth JI, Volden V, Schwarze PE, Lag M, Refsnes M. 2008. IL-1beta differently involved in IL-8 and FGF-2 release in crystalline silica-treated lung cell co-cultures. Part Fibre Toxicol 5:16.

Hussain SM, Hess KL, Gearhart JM, Geiss KT, Schlager JJ. 2005. In vitro toxicity of nanoparticles in BRL 3A rat liver cells. Toxicol In Vitro 19(7):975-83.

ICCVAM. 2001. Guidance Document on Using In Vitro Data to Estimate In Vivo Starting Doses for Acute Toxicity. NIH Publication No: 01-4500. National Institutes of Health, Research Triangle Park, NC (2001). Research Triangle Park, NC: National Institutes of Health.

International Commission on Radiological Protection (ICRP). 1994. Publication 66: Human respiratory tract model for radiological protection. Ann. ICRP Oxford: Permagon Press.

Jin Y, Kannan S, Wu M, Zhao JX. 2007. Toxicity of luminescent silica nanoparticles to living cells. Chem Res Toxicol 20(8):1126-33.

Kagan VE, Tyurina YY, Tyurin VA, Konduru NV, Potapovich AI, Osipov AN, Kisin ER, Schwegler-Berry D, Mercer R, Castranova $V$ et al. 2006. Direct and indirect effects of single walled carbon nanotubes on RAW 264.7 macrophages: role of iron. Toxicol Lett 165(1):88-100.

Kang JL, Moon C, Lee HS, Lee HW, Park EM, Kim HS, Castranova V. 2008. Comparison of the biological activity between ultrafine and fine titanium dioxide particles in RAW 264.7 cells associated with oxidative stress. J Toxicol Environ Health A 71(8):478-85. 
Karlsson HL, Cronholm P, Gustafsson J, Moller L. 2008. Copper Oxide Nanoparticles Are Highly Toxic: A Comparison between Metal Oxide Nanoparticles and Carbon Nanotubes. Chem Res Toxicol 21(9):1726-32.

Kisin ER, Murray AR, Keane MJ, Shi XC, Schwegler-Berry D, Gorelik O, Arepalli S, Castranova V, Wallace WE, Kagan VE et al. 2007. Single-walled carbon nanotubes: geno- and cytotoxic effects in lung fibroblast V79 cells. J Toxicol Environ Health A 70(24):2071-9.

Kroll A, Pillukat MH, Hahn D, Schnekenburger J. 2008. Current in vitro methods in nanoparticle risk assessment: Limitations and challenges. Eur J Pharm Biopharm:doi:10.1016/j. ejpb.2008.08.009

Li SD, Huang L. 2008. Pharmacokinetics and biodistribution of nanoparticles. Mol Pharm 5(4):496504.

Limbach LK, Wick P, Manser P, Grass RN, Bruinink A, Stark WJ. 2007. Exposure of engineered nanoparticles to human lung epithelial cells: influence of chemical composition and catalytic activity on oxidative stress. Environ Sci Technol 41(11):4158-63.

Lison D, Thomassen LC, Rabolli V, Gonzalez L, Napierska D, Seo JW, Kirsch-Volders M, Hoet P, Kirschhock CE, Martens JA. 2008. Nominal and effective dosimetry of silica nanoparticles in cytotoxicity assays. Toxicol Sci 104(1):155-62.

Lorenz MR, Holzapfel V, Musyanovych A, Nothelfer K, Walther P, Frank H, Landfester K, Schrezenmeier $\mathrm{H}$, Mailander V. 2006. Uptake of functionalized, fluorescent-labeled polymeric particles in different cell lines and stem cells. Biomaterials 27(14):2820-8.

Lundqvist M, Stigler J, Elia G, Lynch I, Cedervall T, Dawson KA. 2008. Nanoparticle size and surface properties determine the protein corona with possible implications for biological impacts. Proc Natl Acad Sci U S A 105(38):14265-70.

Monteiller C, Tran L, MacNee W, Faux S, Jones A, Miller B, Donaldson K. 2007. The pro-inflammatory effects of low-toxicity low-solubility particles, nanoparticles and fine particles, on epithelial cells in vitro: the role of surface area. Occup Environ Med 64(9):609-15.

Monteiro-Riviere NA, Inman AO, Zhang LW. 2009. Limitations and relative utility of screening assays to assess engineered nanoparticle toxicity in a human cell line. Toxicol Appl Pharmacol 234(2):222-35.

Muller J, Decordier I, Hoet PH, Lombaert N, Thomassen L, Huaux F, Lison D, Kirsch-Volders M. 2008. Clastogenic and aneugenic effects of multi-wall carbon nanotubes in epithelial cells. Carcinogenesis 29(2):427-33.

Murdock RC, Braydich-Stolle L, Schrand AM, Schlager JJ, Hussain SM. 2008. Characterization of nanomaterial dispersion in solution prior to in vitro exposure using dynamic light scattering technique. Toxicol Sci 101(2):239-253.

Nel A, Xia T, Madler L, Li N. 2006. Toxic potential of materials at the nanolevel. Science 311(5761):622-7.

Oberdorster G, Maynard A, Donaldson K, Castranova V, Fitzpatrick J, Ausman K, Carter J, Karn B, Kreyling W, Lai $D$ et al. 2005. Principles for characterizing the potential human health effects from exposure to nanomaterials: elements of a screening strategy. Part Fibre Toxicol 2:8.

Park EJ, Choi J, Park YK, Park K. 2008. Oxidative stress induced by cerium oxide nanoparticles in cultured BEAS-2B cells. Toxicology 245(1-2):90-100.

Rothen-Rutishauser B, Blank F, Muhlfeld C, Gehr P. 2008. In vitro models of the human epithelial airway barrier to study the toxic potential of particulate matter. Expert Opin Drug Metab Toxicol 4(8):1075-89. 
Sadauskas E, Wallin H, Stoltenberg M, Vogel U, Doering P, Larsen A, Danscher G. 2007. Kupffer cells are central in the removal of nanoparticles from the organism. Part Fibre Toxicol 4:10.

Sager TM, Porter DW, Robinson VA, Lindsley WG, Schwegler-Berry DE, Castranova V. 2007. Improved method to disperse nanoparticles for in vitro and in vivo investigation of toxicity. Nanotoxicology 1(2):118-129.

Sayes CM, Reed KL, Warheit DB. 2007. Assessing toxicity of fine and nanoparticles: comparing in vitro measurements to in vivo pulmonary toxicity profiles. Toxicol Sci 97(1):163-80.

Sayes CM, Wahi R, Kurian PA, Liu Y, West JL, Ausman KD, Warheit DB, Colvin VL. 2006. Correlating nanoscale titania structure with toxicity: a cytotoxicity and inflammatory response study with human dermal fibroblasts and human lung epithelial cells. Toxicol Sci 92(1):174-85.

SCENIHR. 2007. Opinion on the appropriateness of the risk assessment methodology in accordance with the technical guidance documents for new and existing substances for assessing the risks of nanomaterials, adopted at the 19th plenary meeting on 21-22 June 2007 after public consultation. European Commission, Brussels, Belgium. European Commission.

SCENIHR. 2009. Risk Assessment of Products of Nanotechnologies, adopted the 28th plenary meeting on 19 January 2009. European Commission, Brussels, Belgium.: European Commission.

Schulze S, Kroll A, Lehr C, Schäfer UF, Becker K, Schnekenburger J, Isfort CS, Landsiedel R, Wohlleben W. 2008. Not ready to use - overcoming pitfalls when dispersing nanoparticles in physiological media. Nanotoxicology 2(2):51-61.

Semmler-Behnke M, Kreyling WG, Lipka J, Fertsch S, Wenk A, Takenaka S, Schmid G, Brandau W. 2008. Biodistribution of 1.4- and 18-nm gold particles in rats. Small 4(12):2108-11.

Service RF. 2008. Nanotechnology. Can high-speed tests sort out which nanomaterials are safe? Science 321(5892):1036-7.

Shaw SY, Westly EC, Pittet MJ, Subramanian A, Schreiber SL, Weissleder R. 2008. Perturbational profiling of nanomaterial biologic activity. Proc Natl Acad Sci U S A 105(21):7387-92.

Simon-Deckers A, Gouget B, Mayne-L'hermite M, Herlin-Boime N, Reynaud C, Carriere M. 2008. In vitro investigation of oxide nanoparticle and carbon nanotube toxicity and intracellular accumulation in A549 human pneumocytes. Toxicology 253(1-3):137-146.

Teeguarden JG, Hinderliter PM, Orr G, Thrall BD, Pounds JG. 2007. Particokinetics in vitro: dosimetry considerations for in vitro nanoparticle toxicity assessments. Toxicol Sci 95(2):300-12.

Vallhov H, Qin J, Johansson SM, Ahlborg N, Muhammed MA, Scheynius A, Gabrielsson S. 2006. The importance of an endotoxin-free environment during the production of nanoparticles used in medical applications. Nano Lett 6(8):1682-6.

Veranth JM, Kaser EG, Veranth MM, Koch M, Yost GS. 2007. Cytokine responses of human lung cells (BEAS-2B) treated with micron-sized and nanoparticles of metal oxides compared to soil dusts. Part Fibre Toxicol 4:2.

Waldman WJ, Kristovich R, Knight DA, Dutta PK. 2007. Inflammatory properties of iron-containing carbon nanoparticles. Chem Res Toxicol 20(8):1149-54.

Wang JJ, Sanderson BJ, Wang H. 2007. Cyto- and genotoxicity of ultrafine $\mathrm{TiO}_{2}$ particles in cultured human lymphoblastoid cells. Mutat Res 628(2):99-106.

Warheit DB. 2008. How meaningful are the results of nanotoxicity studies in the absence of adequate material characterization. Toxicol Sci 101(2):183-185.

Worle-Knirsch JM, Pulskamp K, Krug HF. 2006. Oops they did it again! Carbon nanotubes hoax scientists in viability assays. Nano Lett 6(6):1261-8. 
Xia T, Kovochich M, Brant J, Hotze M, Sempf J, Oberley T, Sioutas C, Yeh JI, Wiesner MR, Nel AE. 2006. Comparison of the abilities of ambient and manufactured nanoparticles to induce cellular toxicity according to an oxidative stress paradigm. Nano Lett 6(8):1794-807.

Yamamoto A, Honma R, Sumita M, Hanawa T. 2004. Cytotoxicity evaluation of ceramic particles of different sizes and shapes. J Biomed Mater Res A 68(2):244-56.

Yang H, Liu C, Yang D, Zhang H, Xi Z. 2009. Comparative study of cytotoxicity, oxidative stress and genotoxicity induced by four typical nanomaterials: the role of particle size, shape and composition. J Appl Toxicol 29(1):69-78.

Yang W, Peters JI, Williams RO, 3rd. 2008. Inhaled nanoparticles--a current review. Int J Pharm 356(1-2):239-47. 




\title{
CHAPTER 3
}

\section{IN VITRO DEVELOPMENTAL TOXICITY TEST DETECTS INHIBITION OF STEM CELL DIFFERENTIATION BY SILICA NANOPARTICLES}

\author{
Margriet V.D.Z. Park ${ }^{1,2}$ \\ Wijtske Annema ${ }^{1}$ \\ Anna Salvati ${ }^{3}$ \\ Anna Lesniak ${ }^{3}$ \\ Andreas Elsaesser ${ }^{4}$ \\ Clifford Barnes ${ }^{4}$ \\ George McKerr ${ }^{4}$ \\ C. Vyvyan Howard ${ }^{4}$ \\ Iseult Lynch ${ }^{3}$ \\ Kenneth A. Dawson ${ }^{3}$ \\ Aldert H. Piersma ${ }^{1,5}$ \\ Wim H. de Jong ${ }^{1}$
}

Toxicology and Applied Pharmacology 240: 108-116, 2009

${ }^{1}$ Laboratory for Health Protection Research, National Institute for Public Health and the Environment, 3720 BA, Bilthoven, the Netherlands

${ }^{2}$ Department of Health Risk Analysis and Toxicology, Maastricht University, 6200 MD Maastricht, The Netherlands

${ }^{3}$ Centre for BioNano Interactions, School of Chemistry and Chemical Biology, University College Dublin, Belfield, Dublin 4, Ireland

${ }^{4}$ Centre for Molecular Bioscience, University of Ulster, Coleraine, BT52 1SA, United Kingdom ${ }^{5}$ Institute for Risk Assessment Sciences, University of Utrecht, 3508 TD, Utrecht, The Netherlands 


\section{ABSTRACT}

While research into the potential toxic properties of ENMs is now increasing, the area of developmental toxicity has remained relatively uninvestigated. The embryonic stem cell test is an in vitro screening assay used to investigate the embryotoxic potential of chemicals by determining their ability to inhibit differentiation of embryonic stem cells into spontaneously contracting cardiomyocytes.

Four well characterized $\mathrm{SiO}_{2}$ NPs of various sizes were used to investigate whether ENMs are capable of inhibition of differentiation in the embryonic stem cell test. NP size distributions and dispersion characteristics were determined before and during incubation in the stem cell culture medium by means of transmission electron microscopy (TEM) and dynamic light scattering.

Mouse embryonic stem cells were exposed to $\mathrm{SiO}_{2} \mathrm{NPs}$ at concentrations ranging from 1 to $100 \mu \mathrm{g} / \mathrm{ml}$. The embryonic stem cell test detected a concentration dependent inhibition of differentiation of stem cells into contracting cardiomyocytes by two $\mathrm{SiO}_{2}$ NPs of primary size 11 and $34 \mathrm{~nm}$ while two other particles of primary size 34 and $248 \mathrm{~nm}$ had no effect up to the highest concentration tested.

Inhibition of differentiation of stem cells occurred below cytotoxic concentrations, indicating a specific effect of the particles on the differentiation of the embryonic stem cells. The impaired differentiation of stem cells by such widely used particles warrants further investigation into the potential of these NPs to migrate into the uterus, placenta and embryo and their possible effects on embryogenesis.

\subsection{INTRODUCTION}

There is an ongoing debate whether current risk governance systems are appropriate for ENMs, including the nanoforms of common materials such as $\mathrm{SiO}_{2}$ (Renn and Roco 2006). To facilitate a faster risk assessment procedure for promising nanotechnology products, the use of in vitro studies has been suggested as a rapid approach to distinguish between low and high toxicity ENMs (Nel et al. 2006; Service 2008; Shaw et al. 2008). Numerous in vitro studies investigating the cytotoxic, oxidative stress and inflammation potential of ENMs are now published, although their value for predicting in vivo toxicity still remains to be demonstrated (Park et al. 2009; Sayes et al. 2007). Other toxicity endpoints such as carcinogenicity, immunotoxicity, reproductive and developmental toxicity are scarcely investigated. Evaluation of these types of toxicity endpoints often require long in vivo exposure studies, but are nonetheless relevant endpoints to include in risk assessments of ENMs.

An inventory of nanotechnology-based consumer products currently on the market lists various products that claim use of ENMs, including paint, cosmetics, personal care products 
and food supplements, although the presence of nanoscale entities in these products has not been verified (Woodrow Wilson International Center for Scholars 2008). Emerging applications of ENMs in biomedical and biotechnological fields include biosensors (Zhang et al. 2004), biomarkers (Santra et al. 2001), cancer therapy (Hirsch et al. 2003), DNA delivery systems (Bharali et al. 2005), drug delivery systems (De Jong and Borm 2008) and enzyme immobilization (Qhobosheane et al. 2001). Hence, human exposure to ENMs may involve inhalation, ingestion and dermal routes. Moreover, these particles may be directly injected into the human body for medical purposes. Once systemically available, various types of ENMs appear capable of distributing to most organ systems and even may cross biological barriers, such as the blood-brain and blood-testis barriers (Kwon et al. 2008; Semmler et al. 2004). Since the number of applications of ENMs is expected to rise even more in the future, long term exposure and potential accumulation of these ENMs in the human body may result.

Scarce and inconsistent information exists on the ability of ENMs to penetrate across the placental barrier and evoke embryotoxic effects. Sadauskas et al. (2007) injected pregnant mice intravenously with either $2 \mathrm{~nm}$ or $40 \mathrm{~nm}$ Au NPs in their 16-18 $8^{\text {th }}$ day of pregnancy. No NPs could be detected in either the placenta or the fetuses (Sadauskas et al. 2007). These findings were supported by Challier et al. (1973) who demonstrated impermeability of rat placenta to $4-200 \mathrm{~nm}$ radio labeled Au colloid particles in both directions, i.e. mother-fetus and fetus-mother (Challier et al. 1973). However, when rats were exposed intravenously to $5 \mathrm{~nm}$ and $30 \mathrm{~nm}{ }^{198} \mathrm{Au}$ particles a limited transfer of these particles to the fetus was found, i.e. 0.018 and $0.05 \%$ for 5 and $30 \mathrm{~nm}$ particles, respectively (Takahashi and Matsuoka 1981). Additional evidence that small amounts of radiolabeled Au can transfer across the placenta in rats was recently published (Semmler-Behnke et al. 2008). Malformations found in embryos after intravenous exposure of pregnant mice to fullerene $C_{60}$ also indicate transfer of these particles to the conceptus (Tsuchiya et al. 1996). In addition, exposure of zebrafish embryos to fullerene $C_{60}$ NPs resulted in malformations and mortality (Usenko et al. 2008; Zhu et al. 2007). In contrast, Bosman et al. demonstrated that in vitro exposure of mouse embryos to polystyrene-based NPs did not affect the development to the blastocyst stage (Bosman et al. 2005). These contradicting results may be attributable to the use of different ENMs, but also to the exposure occurring during different stages of embryo development as well as differences in experimental models.

The embryonic stem cell test (EST) was validated as an in vitro developmental toxicity test discriminating between chemicals in three classes of embryotoxicity (Genschow et al. 2004b). It investigates the potential of test compounds to inhibit the differentiation of embryonic stem cells (D3 cells) into spontaneously contracting cardiomyocytes and is regarded as a promising alternative in vitro method to in vivo developmental toxicity studies (Genschow et al. 2004a). To our knowledge this assay has not previously been applied to test ENMs. The aim of this study was to investigate the effect of four well characterized $\mathrm{SiO}_{2} \mathrm{NPs}$ of different sizes in the embryonic stem cell test. 


\subsection{MATERIALS AND METHODS}

\subsubsection{Nanoparticles}

The NPs used in this study were spherical amorphous $\mathrm{SiO}_{2}$ NPs of four different nominal sizes obtained from Glantreo Ltd., Cork, Ireland. These $\mathrm{SiO}_{2}$ particles were synthesized via the Stöber method without any stabilizer (Stöber et al. 1968). The manufacturer's specifications indicated that the particle solutions contained spherical $\mathrm{SiO}_{2} \mathrm{NPs}$ with an average primary particle size of $10,30,80$ and $400 \mathrm{~nm}$, respectively.

In order to clean the particle suspensions from synthesis residues and solvents that may affect toxicity, the NPs were dialyzed extensively against a very large excess of pure MilliQ water. Sample concentration after dialysis was determined by freeze drying three aliquots of the dialyzed nanoparticle sample for $48 \mathrm{~h}$ and weighing the final $\mathrm{SiO}_{2}$ material. Endotoxin concentration was below the detection limit as analyzed by the Limulus Amoebocyte Lysate (Gel-clot) assay. Moreover, NP stock solutions were void of bacterial and/or fungal infections, as tested by inoculation on Columbia sheep blood agar plates (Oxoid Ltd).

The morphology, mean diameter and aggregation status of the dried $\mathrm{SiO}_{2}$ particles was assessed using transmission electron microscopy (TEM) using methods described previously (Barnes et al. 2008). In brief, particles were deposited in suspension onto carbon film TEM grids and left to dry in air. Mean particle size was determined by measuring more than 100 randomly sampled individual particles.

\subsubsection{Dynamic Light Scattering}

Dynamic light scattering (DLS) measurements using a Malvern 3000HS Zetasizer photon correlation spectrophotometer were carried out to determine the hydrodynamic particle size of the $\mathrm{SiO}_{2}$ particles in deionized water shortly after dispersion as described previously (Barnes et al. 2008) and in D3 cell culture medium as a function of time (shortly after dispersion, 24 hours and 5 days after dispersion). For these studies, particles were dispersed in D3 cell culture medium at $100 \mu \mathrm{g} / \mathrm{ml}$, corresponding to the highest particle concentration studied in the embryonic stem cell test.

\subsubsection{Cell culture}

The D3 murine embryonic stem cell line was purchased from American Type Culture Collection (ATCC, Rockville, USA). Cells were maintained in Dulbecco's Modified Eagle Medium (DMEM, Gibco, cat. nr. 41965, Breda, The Netherlands) supplemented with $20 \%$ FCS (HyClone, Logan, USA), 2 mM L-glutamine (Gibco, Breda, The Netherlands), $50 \mathrm{U} / \mathrm{ml}$ penicillin and $50 \mu \mathrm{g} / \mathrm{ml}$ streptomycin (Gibco, Breda, The Netherlands), 1\% non-essential amino acids (NEAA, Gibco, Breda, The Netherlands) and $0.1 \mathrm{mM} \beta$-mercaptoethanol (SigmaAldrich, Schnelldorf, Germany) in the presence of $1000 \mathrm{U} / \mathrm{ml}$ murine Leukemia Inhibiting Factor (mLIF; ESGRO, Chemicon, Billerica, USA) in a humidified atmosphere of $5 \% \mathrm{CO}_{2}$ and 
$37^{\circ} \mathrm{C}$. The addition of $\mathrm{mLIF}$ serves to inhibit spontaneous differentiation of the embryonic stem cells into major embryonic tissues. The D3 embryonic stem cells were routinely cultured in 35x10 mm culture dishes (Corning, Sigma-Aldrich, Schnelldorf, Germany) coated with a $0.1 \%$ gelatin solution and sub-cultivated using non-enzymatic cell dissociation buffer (Gibco, Breda, The Netherlands) upon reaching 60-80\% confluence. Particle exposure experiments were performed using D3 cells between passages 11 and 25 .

\subsubsection{Embryonic stem cell test}

The embryonic stem cell test was applied to predict the embryotoxic potential of the four $\mathrm{SiO}_{2}$ NPs. This in vitro developmental toxicity test is based on the culture of D3 embryonic stem cells in hanging drops of cell culture medium. Under these conditions, cells will form embryoid bodies and upon plating onto tissue culture plastics, they will differentiate into contracting cardiomyocytes (Scholz and Spielman 2000). This differentiation process may be impaired by toxic agents.

Stock solutions of $\mathrm{SiO}_{2}$ NPs were diluted serially in distilled water (AD) to yield concentrations ranging from 10 to $1000 \mu \mathrm{g} / \mathrm{ml}$. These samples were then thoroughly vortexed before dilution 10 times with cell culture medium, immediately before use. The embryonic stem cells were thus exposed to end concentrations ranging from 1 to $100 \mu \mathrm{g} /$ $\mathrm{ml}$, throughout the entire 10-day test period of the differentiation assay. As a positive control, cells were exposed to 5-fluorouracil at an embryotoxic concentration of $0.045 \mu \mathrm{g} /$ $\mathrm{ml}$. On day 0 of the assay, embryonic stem cells were harvested and a cell suspension of $15 \times 10^{4}$ cells $/ \mathrm{ml}$ was prepared. Subsequently, $500 \mu \mathrm{l}$ cell suspension was added to $1.5 \mathrm{ml}$ freshly prepared cell culture medium containing $\mathrm{SiO}_{2}$ particles, $\mathrm{AD}$ or 5 -fluorouracil and suspensions were placed on ice. Subsequently, cells in the suspension $\left(3.75 \times 10^{4}\right.$ cells/ $\mathrm{ml}$ ) were allowed to aggregate by preparing so called "hanging drops". For each exposure concentration, 70 drops of $20 \mu$ cell suspension were placed on the lid of a cell culture dish (Greiner, Sigma-Aldrich, Schnelldorf, Germany) filled with $5 \mathrm{ml}$ phosphate buffered saline (PBS). These hanging drops were then cultured in a humidified atmosphere at $37^{\circ} \mathrm{C}$ in $5 \% \mathrm{CO}_{2}$. On day 3 , the cell aggregates (embryoid bodies) were transferred with $5 \mathrm{ml}$ cell culture medium containing $\mathrm{SiO}_{2}$ particles, $\mathrm{AD}$ or 5-fluorouracil to a bacterial petri dish (Greiner, Sigma-Aldrich, Schnelldorf, Germany) and further cultured in suspension. On day 5, the embryoid bodies were plated in 24-wells plates (TPP, Sigma-Aldrich, Schnelldorf, Germany) containing 1 embryoid body in $1 \mathrm{ml}$ cell culture medium with $\mathrm{SiO}_{2}$ particles, $A D$ or 5-fluorouracil per well. For analysis of cell differentiation, on day 10 the number of wells containing embryoid bodies with spontaneously contracting myocardial foci was determined by phase contrast microscopy and expressed as the percentage of wells containing spontaneously contracting cardiomyocytes. For each exposure concentration, 24 embryoid bodies were evaluated for the presence of muscle contracting activity. The data of an individual embryonic stem cell test were considered valid when at least $75 \%$ of the embryoid bodies had differentiated to contracting myocardial cells in the solvent 
control. When the solvent control showed contracting activity of 70.8-87.5\% (17 of 21 21 of 24), assays were accepted when in the lowest test concentrations the limit of $87.5 \%$ was reached. At least three independent experiments were performed for each $\mathrm{SiO}_{2} \mathrm{NP}$.

\subsubsection{Uptake of silica nanoparticles in embryoid bodies}

To determine whether $\mathrm{SiO}_{2}$ NPs were taken up in the cells of the embryoid bodies, the embryonic stem cells were allowed to form embryoid bodies following the same procedures of the embryonic stem cell test up to day 3, as described above. During the formation of the embryoid bodies, embryonic stem cells were exposed to concentrations of $100 \mu \mathrm{g} / \mathrm{ml}$ of each $\mathrm{SiO}_{2}$ nanoparticle, or to $10 \%$ AD. On day 3 , the embryoid bodies were transferred to Karnovsky fixative containing 2\% paraformaldehyde, 2.5\% glutaraldehyde, $80 \mathrm{mM}$ sodiumcacodylate buffer, $0.25 \mathrm{mM}$ calcium chloride, $0.5 \mathrm{mM}$ magnesiumchloride and adjusted to $\mathrm{pH}$ 7.4. Following a wash in phosphate buffered saline (PBS) the embryoid bodies were post-fixed in 1\% osmium tetroxide (Agar Scientific) for 1 hour. The embryoid bodies were rinsed in PBS and subsequently dehydrated in a graded ethanol series (70\%, $80 \%, 90 \%$ ) for 30 mins each and twice in $100 \%$ ethanol for 15 mins. The samples were then infiltrated in increasing proportions of Low Viscosity Spurr resin (SPI Supplies) (3:1, 1:1, $1: 3)$ for 1 hour each before a final infiltration step in 100\% resin. The samples were placed in a vacuum ( $4 \mathrm{kPa}$ ) for 30 mins during the last infiltration step. Fresh resin was then added and the samples were allowed to polymerize at $70^{\circ} \mathrm{C}$ for 24 hours. $100 \mathrm{~nm}$ thin sections were cut in an ultramicrotome (RMC, PowerTomeXL) using a diamond knife (Drukker). Samples were imaged with a transmission electron microscope (FEl company, Tecnai G2 Spirit Biotwin) at an operating voltage of $120 \mathrm{kV}$.

\subsubsection{WST-1 cell metabolic activity assay}

The metabolic activity of the D3 cells was determined after both $24 \mathrm{~h}$ and 10 days of exposure to the $\mathrm{SiO}_{2}$ NPS, using a standard WST-1 assay. The WST-1 cytotoxicity test is based on the cleavage of the tetrazolium salt 4-[3-(4-lodophenyl)-2-(4-nitrophenyl)-2H-5tetrazolio]-1,3-benzene disulfonate (WST-1) to soluble formazan dye by a complex cellular mechanism depending on the glycolytic production of $\mathrm{NAD}(\mathrm{P}) \mathrm{H}$ in viable cells.

The stock solution of the $\mathrm{SiO}_{2}$ NPs was diluted serially in AD to yield concentrations ranging from 3 to $1000 \mu \mathrm{g} / \mathrm{ml}$ for the cytotoxicity assays. These samples were then thoroughly vortexed before dilution 10 times with cell culture medium, immediately before the start of the experiment. The end concentrations of the NPs in the cell culture medium thus ranged from 0.3 to $100 \mu \mathrm{g} / \mathrm{ml}$. As a positive control for cytotoxicity, cells were incubated with $5 \%$ dimethyl sulfoxide (DMSO). Cells exposed to $10 \%$ AD served as solvent controls in each cytotoxicity experiment.

For the 24 hour cytotoxicity assays, the D3 cells were seeded in 96-well tissue grade microtiter plates at a density of $2 \times 10^{4}$ cells/well and cultured for $24 \mathrm{~h}$ in a humidified atmosphere at $37^{\circ} \mathrm{C}$ and $5 \% \mathrm{CO}_{2}$ to obtain a confluent monolayer. Then, the cell culture 
medium was removed and $100 \mu \mathrm{l}$ of the cell culture medium containing test substances was immediately applied to the each well. After $24 \mathrm{~h}$ exposure in a humidified atmosphere at $37^{\circ} \mathrm{C}$ and $5 \% \mathrm{CO}_{2}$, the cytotoxicity was evaluated. The morphological changes and cell confluence were observed under an inverted phase-contrast microscope. Next, $10 \mu$ l Cell Proliferation Reagent WST-1 (Roche, Almere, The Netherlands) was added to each well. The 96-well tissue grade microtiter plates were placed in a humidified atmosphere of $5 \%$ $\mathrm{CO}_{2}$ and $37^{\circ} \mathrm{C}$ and incubated for $3 \mathrm{~h}$. Subsequently, absorbance of the wells was measured using a SpectraMax ${ }^{\circledR} 190$ scanning multiwell spectrophotometer (Molecular Devices, Sunnyvale, USA) at a wavelength of $440 \mathrm{~nm}$ and a reference wavelength of $620 \mathrm{~nm}$. Data were acquired by applying SoftMax Pro 5 software (Molecular Devices, Sunnyvale, USA). To express the cytotoxicity, the average absorbance of the wells containing cell culture medium without cells was subtracted from the average absorbance of the solvent control, $5 \%$ DMSO or $\mathrm{SiO}_{2}$ NP treated cells. The percentage cell viability was calculated using the following equation:

$$
\frac{\text { Absorbance }_{\text {treated }}}{\text { Absorbance }_{\text {solvent control }}} \times 100 \%
$$

For the 10 day cytotoxicity assays, D3 cells were seeded in 96-well tissue grade microtiter plates at a density of $5 \times 10^{2}$ cells/well and allowed to attach for at least 2 $\mathrm{h}$ in a humidified atmosphere at $37^{\circ} \mathrm{C}$ and $5 \% \mathrm{CO}_{2}$. Next, $150 \mu \mathrm{l}$ cell culture medium containing test substances was added to the D3 cells and the cells were cultured in a humidified atmosphere of $5 \% \mathrm{CO}_{2}$ and $37^{\circ} \mathrm{C}$. On days 3,5 and 7 the cell culture medium was aspirated and D3 cells were exposed to $200 \mu \mathrm{l}$ of freshly prepared cell culture medium containing particles or control substances. Metabolic activity of the cells was assessed on day 10 as described above. At least three independent experiments were performed for each $\mathrm{SiO}_{2}$ nanoparticle.

\subsubsection{Interference of nanoparticles with the WST-1 assay}

There are various ways in which the $\mathrm{SiO}_{2}$ NPs may interfere with the WST-1 based cytotoxicity assay. Therefore, two different WST-1 interference tests were performed. The first interference test is designed to assess whether $\mathrm{SiO}_{2}$ NPs 1 ) scatter or absorb light or 2) interfere with the WST-1 reagent. In a 96-well tissue grade microtiter plate either $100 \mu$ l of cell culture medium or cell culture medium containing $\mathrm{SiO}_{2}$ NPs in the three highest test concentrations (10, 30 and $100 \mu \mathrm{g} / \mathrm{ml}$ ) was added to the wells (without cells). Next, the plate was placed for $24 \mathrm{~h}$ in a humidified atmosphere of $5 \% \mathrm{CO}_{2}$ and $37^{\circ} \mathrm{C}$. Following this incubation period, $10 \mu \mathrm{l}$ of Cell Proliferation Reagent WST-1 (Roche, Almere, the Netherlands) was added to each well and the plate was incubated for $3 \mathrm{~h}$ in a humidified atmosphere of $5 \% \mathrm{CO}_{2}$ and $37^{\circ} \mathrm{C}$. Absorbance of each well was measured as described above. 

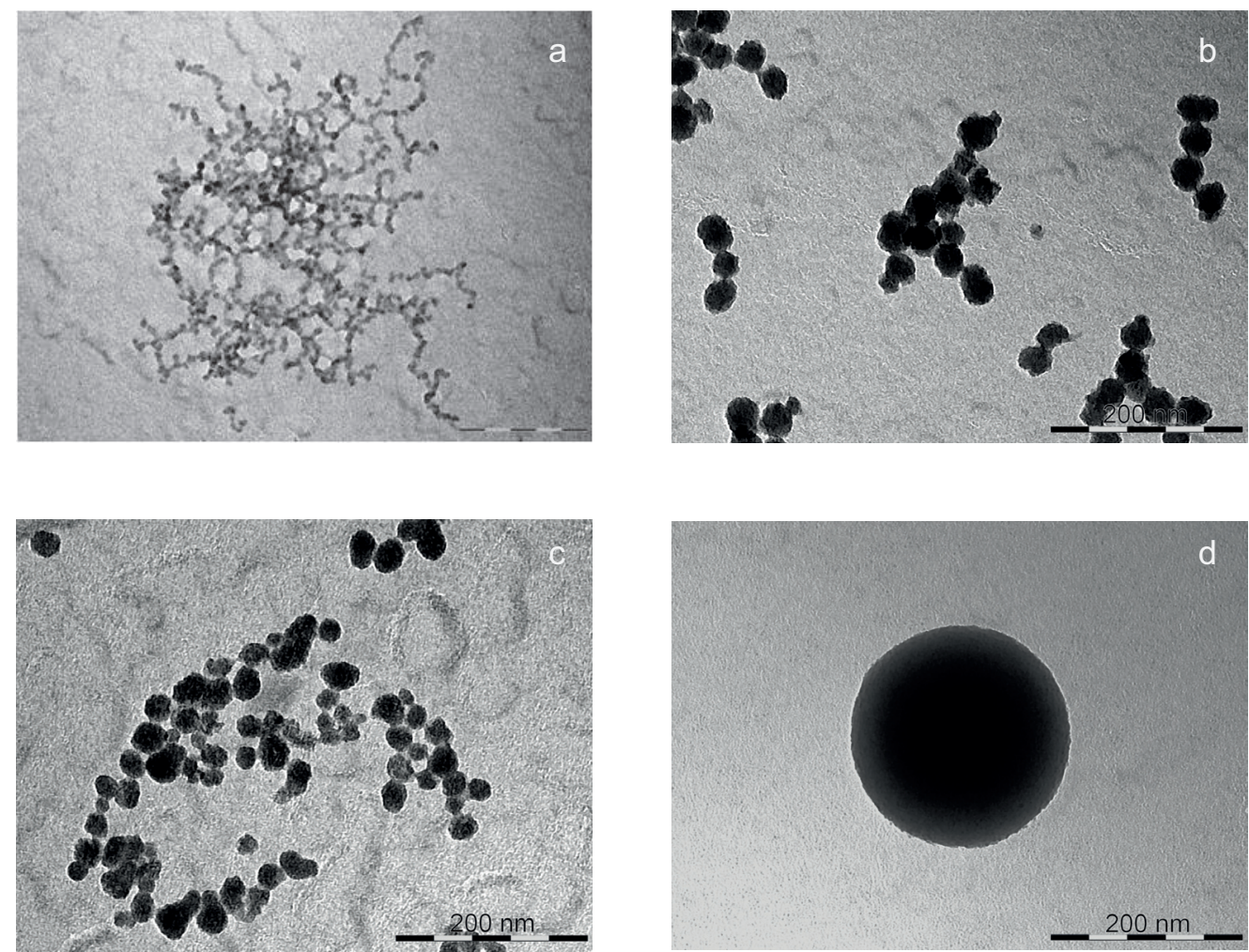

Figure 3.1 Transmission electron microscopy images of (a) 10 (11) nm, (b) 30 (34) nm, (c) 80 (34) nm and (d) 400 (248) nm silica nanoparticles deposited from deionized water.

The second interference test was designed to determine whether $\mathrm{SiO}_{2} \mathrm{NPs}$ interfere with the WST-1 reaction product (formazan). For this test, RAW 264.7 cells were seeded in 96-well tissue grade microtiter plates at a density of $2 \times 10^{4}$ cells/well and cultured for $24 \mathrm{~h}$ at $37^{\circ} \mathrm{C}$ in $5 \% \mathrm{CO}_{2}$. The following day, cell culture medium was removed from the cells and replaced by $100 \mu \mathrm{l}$ fresh cell culture medium. Next, $10 \mu \mathrm{l}$ Cell Proliferation Reagent WST-1 (Roche, Almere, The Netherlands) was added to each well. Following an incubation of $3 \mathrm{~h}$ in a humidified atmosphere of $5 \% \mathrm{CO}_{2}$ and $37^{\circ} \mathrm{C}$, the supernatant was removed from the cells and transferred to a new 96-well tissue grade microtiter plate. Subsequently, absorbance of each well was measured as described above. Next, $10 \mu \mathrm{l}$ DMEM, AD or freshly prepared $\mathrm{SiO}_{2}$ nanoparticle dispersions in $A D$ such that the final concentration in the well was $100 \mu \mathrm{g} / \mathrm{ml}$ was added to the wells and the absorbance was determined once more. The results of both interference tests indicate that the interference of the different $\mathrm{SiO}_{2}$ NPs with the WST-1 reagent and the WST-1 product was negligible (data not shown). 


\subsubsection{Data analysis}

Data are expressed as mean \pm standard deviation (SD). Statistical analysis of the data was performed using SPSS 15.0 software (SPSS Inc., Chicago, USA). Differences in metabolic activity (WST-1) between the NP concentrations and the control were tested by the Kruskal-Wallis and Mann-Whitney non-parametric tests. A $\rho$-value of $<0.05$ was considered statistically significant.

The results of the embryonic stem cell test were analyzed using PROAST software version 14.2b (RIVM, Bilthoven, The Netherlands) (Slob 2002). For the test results from each NP the following log-logistic dose-response model was fitted to the quantal data:

$$
y=a+(1-a) /(1+\exp (c \cdot \ln (b / x))
$$

where $y$ denotes the fraction of embryonic stem cells differentiated in spontaneously contracting myocardial cells, and $x$ the concentration of the test compound. The $\mathrm{ID}_{50}$ was defined as the concentration resulting in a $50 \%$ inhibition of differentiated cell, taken from the differentiated fraction in the solvent control group. In the Benchmark dose (BMD) approach this is equivalent to the dose with $50 \%$ extra risk, so that the BMD software Proast was directly applicable for this analysis. An effect of the particle size on the concentration-differentiation relationship was assessed by comparing the log-likelihood values associated with the model fits with and without defining particle size as a covariate (Slob 2002). A $\rho$-value of $<0.05$ for the associated likelihood-ratio test was considered as a statistically significant effect of particle size.

\subsection{RESULTS}

\subsubsection{Physicochemical characterization}

A complex interplay exists between a particle's surface chemistry and its dispersion medium, involving attractive or repulsive forces amongst particles, between particles and ions, and between particles and biological substances in the dispersion medium such as proteins. These factors affect both the hydrodynamic size and the surface charge (zeta potential) of the particles, and can impact on the agglomeration/aggregation status of the particles, which may in turn affect the extent of toxicity. In analogy with bulk materials, larger agglomerates/aggregates are considered less likely to be toxic than individually dispersed particles or smaller agglomerates/aggregates, which can enter cells (Cedervall et al. 2007; Dutta et al. 2007; Murdock et al. 2008). It has therefore been emphasized that thorough physicochemical characterization of the NPs should be performed in the relevant dispersion medium prior to conducting hazard studies (Oberdorster et al. 2005; Warheit 2008). 


\begin{tabular}{llllll}
$\begin{array}{l}\text { Nominal } \\
\text { size } \\
{[\mathrm{nm}]}\end{array}$ & $\begin{array}{l}\text { TEM }^{a} \\
\text { size } \\
{[\mathrm{nm}]}\end{array}$ & $\begin{array}{l}\text { zeta } \\
\text { potential }\end{array}$ & $\begin{array}{l}\text { pH } \\
{[\mathrm{mV}]}\end{array}$ & $\begin{array}{l}\mathrm{DLS}^{b} \\
\text { size } \\
{[\mathrm{nm}]}\end{array}$ & PDI $^{c}$ \\
\hline 10 & $10.96 \pm 2.21$ & $-43.3 \pm 11.8$ & 7.2 & $103.1 \pm 1.9$ & $0.792 \pm 0.011$ \\
30 & $33.73 \pm 4.00$ & $-33.7 \pm 3.0$ & 6.5 & $77.9 \pm 1.1$ & $0.259 \pm 0.094$ \\
80 & $33.71 \pm 6.12$ & $-10.6 \pm 0.9$ & 6.3 & $65.9 \pm 1.7$ & $0.374 \pm 0.068$ \\
400 & $247.91 \pm 24.05$ & $-49.1 \pm 0.5$ & 8.7 & $269.0 \pm 7.1$ & $0.049 \pm 0.020$ \\
\hline
\end{tabular}

Values given are mean \pm standard deviation. ${ }^{a}$ Transmission Electron Microscopy measurements are the average of at least 100 nanoparticles ${ }^{b}$ Dynamic Light Scattering (DLS) measurements are the average of at least 5 runs each containing 10 sub-measurements. ${ }^{c} \mathrm{PDI}=$ polydispersity index.

Table 3.1 Characterization of silica nanoparticles shortly after dispersion in deionized water.

All $\mathrm{SiO}_{2}$ NPs examined by TEM showed spherical morphologies and no substantial aggregation, except for the $10 \mathrm{~nm}$ particles (Figure 3.1). The measured diameters for the 10 and $30 \mathrm{~nm}$ particles corresponded well with the manufacturer's specifications: 11 $\mathrm{nm}$ and $34 \mathrm{~nm}$, respectively (Table 3.1). In contrast, the measured diameters of the NPs specified as $80 \mathrm{~nm}$ and $400 \mathrm{~nm}$ by the manufacturer were quite different: 34 and 248 $\mathrm{nm}$, respectively. The zetapotentials of the two $34 \mathrm{~nm}$ NPs were quite different, indicating considerable differences in surface properties between the two particles (Table 3.1). For the remainder of this report, the NPs will be referred to as $11 \mathrm{~nm}, 34 \mathrm{~A}, 34 \mathrm{~B}$ and $248 \mathrm{~nm}$ $\mathrm{SiO}_{2}$ NPs.

\subsubsection{Dispersion characteristics}

Dispersion characteristics of $\mathrm{SiO}_{2} \mathrm{NPs}$ over 5 days were studied to understand the nature and evolution of the system over the time course of the cell tests, where the cell culture medium is present for a maximum of 5 days.

DLS data of cell culture medium alone shows the presence of very significant agglomerates/aggregates of sizes ranging from 10 to $100 \mathrm{~nm}$ (Figure 3.2). These are protein clusters likely consisting of apolipoprotein complexes, which typically have sizes in the range of $10-100 \mathrm{~nm}$. The presence of these protein aggregates of this size range complicates the determination of NPs of similar dimensions, therefore the data must be interpreted with caution.

Consistent with the TEM images, the high polydispersity index (PDI) value of the 10 (11) $\mathrm{nm}$ particles dispersed in water indicates the presence of agglomerated or aggregated particle clusters with a wide range of sizes (Table 3.1). The agglomeration/aggregation of the $11 \mathrm{~nm}$ particles appears to persist in the D3 cell culture medium (Figure 3.2a) immediately following dispersion.

In the data for all particles shortly after dispersion in cell culture medium, the first peaks in the region between 10-100 nm overlap with the peak of D3 cell culture medium 
only. The changes in the peak in this region, when compared to cell culture medium only, may be explained by a change in the cell culture medium composition due to adsorption of cell culture medium components onto the $\mathrm{SiO}_{2} \mathrm{NPs}$. For example, a nanoparticle-protein corona may be formed, as described by Lundqvist et al. (2008).
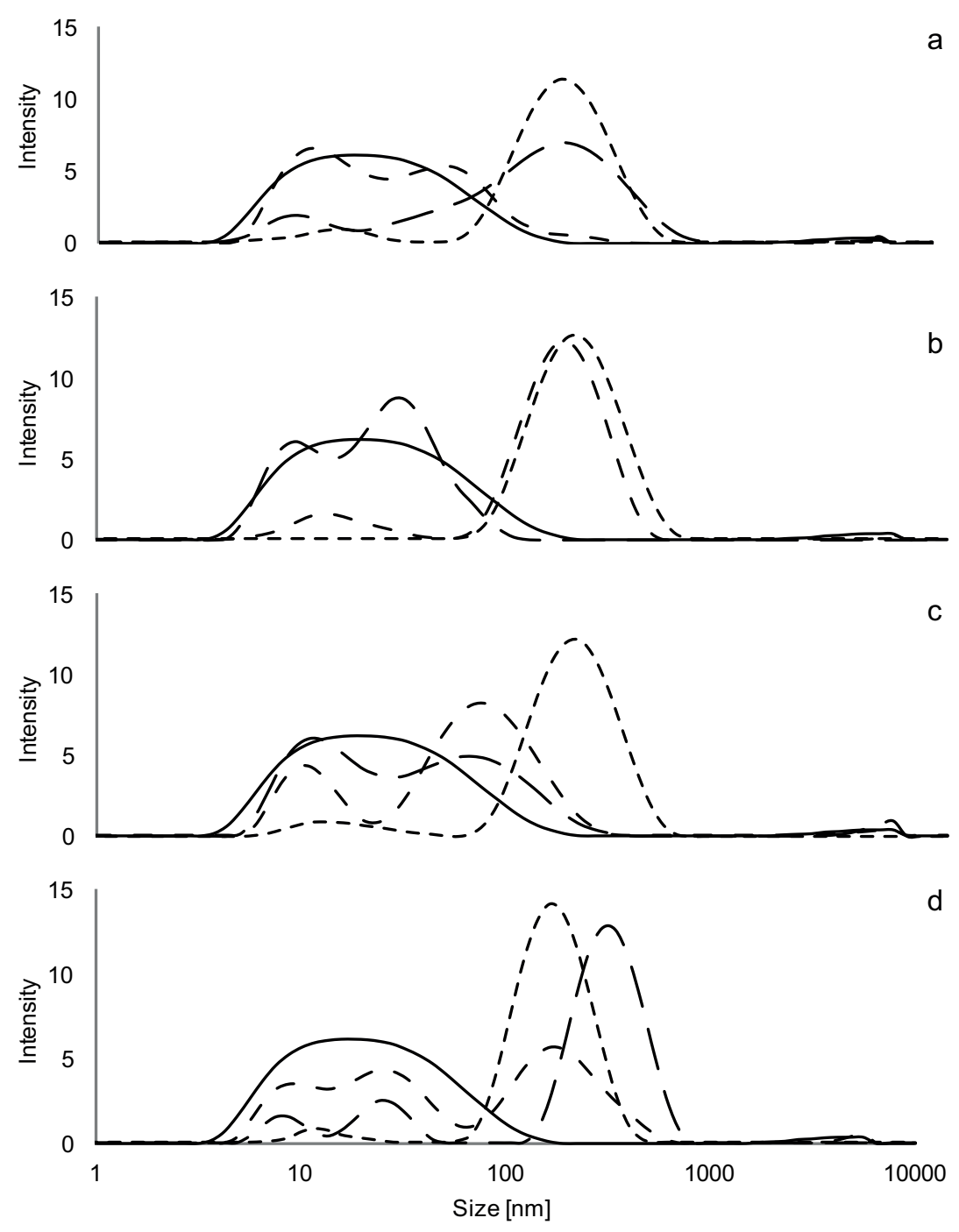

_ cell culture medium _ـ shortly after dispersion

- $-24 \mathrm{~h}$ after dispersion $\quad$ _ -5 days after dispersion

Figure 3.2 Dynamic light scattering of $11 \mathrm{~nm}$ (a), 34A (b), 34B (c) and $248 \mathrm{~nm}$ silica particles dispersed at 100 $\mu \mathrm{g} / \mathrm{ml}$ in D3 cell culture medium shortly after dispersion, 24 hours after dispersion and 5 days after dispersion, and for comparison the scattering of the $\mathrm{D} 3$ cell culture medium alone is also shown. 
For the larger $248 \mathrm{~nm}$ particle, it is likely that the additional peak represents the dispersed particles. This is less clear in the case of the $11 \mathrm{~nm}$ and the two $34 \mathrm{~nm}$ particles, where the peaks for dispersed particles and protein clusters are in overlapping regions, between 10-100 nm.

Shortly after dispersion, 34B NPs had a wider size distribution compared to the 34A NPs, indicating that the 34B NPs were more agglomerated/aggregated in cell culture medium. In contrast, for the $11 \mathrm{~nm}$ NPs, a second peak appears in the 10-100 nm region after 24 hours, possibly representing a significant fraction of dispersed particles. The coating of the $11 \mathrm{~nm}$ NPs with cell culture medium proteins may act to disperse a fraction of the NPs, which were still highly agglomerated/aggregated immediately following dispersion.

After 24 hours, one main peak is clearly visible for the 34A particles at around 130-160 $\mathrm{nm}$, while the first peaks observed shortly after dispersion have almost disappeared. The same trend is observed for the other particles, but only at 5 days after dispersion. At this time point, the data for all particles look remarkably similar. TEM images of particles 5 days after dispersion in D3 cell culture medium show that only a few particles are present in their original state (images not shown) and that the particles are now more agglomerated/aggregated.

Thus, a dynamic interaction between the $\mathrm{SiO}_{2}$ particles and the $\mathrm{D} 3$ cell culture medium is apparent, starting immediately upon contact, and continuing throughout the duration of the study. The two $34 \mathrm{~nm}$ NPs behaved very differently in cell culture medium up to 24 hours after dispersion, despite their nearly identical TEM measured diameters.

It has to be noted that there is a significant limitation to these experiments, which complicates the interpretation of the data. This limitation is the well known limitation of the DLS method whereby it is a weight-averaged measurement biased towards larger particle sizes and especially towards agglomerates/aggregates. Thus, the observed curves could actually contain very high numbers of small particles which are simply not very well detected and resolved by the measurement method. However, given these concerns, there seem to be significant amounts of the $11 \mathrm{~nm}$ and the 34A NPs becoming "bioavailable" shortly after dispersion in cell culture medium, which can interact with the D3 embryonic stem cells.

\subsubsection{Embryonic stem cell test}

In the embryonic stem cell test, at least $75 \%$ of the 24 embryoid bodies in the controls displayed contractility in every experiment, while differentiation of embryoid bodies exposed to 5-fluorouracil was inhibited (data not shown). Both the $11 \mathrm{~nm}$ and the 34A $\mathrm{SiO}_{2}$ NPs were embryotoxic in vitro as reflected by a dose dependent inhibition of the differentiation of the D3 cells into myocardial cells (Figure 3.3). The 34B and $248 \mathrm{~nm} \mathrm{SiO}$ particles did not exhibit any inhibition of the differentiation at concentrations up to 100 $\mu \mathrm{g} / \mathrm{ml}$. The differentiating inhibiting potency of the $34 \mathrm{~A} \mathrm{SiO}_{2}$ particles was significantly higher than that of the $11 \mathrm{~nm}$ particles as evidenced by the estimated ID ${ }_{50}$ values of $29 \mu \mathrm{g} /$ $\mathrm{ml}$ and $59 \mu \mathrm{g} / \mathrm{ml}$, respectively $(\mathrm{p}<0.01)$. The relation between the $I_{50}$ expressed as mass, number concentration and surface area is presented in Table 3.2. 


\begin{tabular}{llll}
$\begin{array}{l}\text { TEM size } \\
{[\mathrm{nm}]}\end{array}$ & $\begin{array}{l}\text { Mass } \\
{[\mu \mathrm{g} / \mathrm{ml}]}\end{array}$ & $\begin{array}{l}\text { Number } \\
{[\# \text { particles/ml] }}\end{array}$ & $\begin{array}{l}\text { Surface area } \\
{\left[\mathrm{cm}^{2} / \mathrm{ml}\right]}\end{array}$ \\
\hline 11 & 59 & $3.9 \times 10^{13}$ & 146 \\
$34 \mathrm{~A}$ & 29 & $6.4 \times 10^{11}$ & 23 \\
$34 \mathrm{~B}$ & $>100$ & $>2.2 \times 10^{12}$ & $>80$ \\
248 & $>100$ & $>5.7 \times 10^{9}$ & $>11$ \\
\hline
\end{tabular}

${ }^{\mathrm{a}}$ TEM: Transmission Electron Microscopy

Table 3.2 The $\mathrm{ID}_{50}$ dose inhibiting embryonic stem cell differentiation expressed as mass, number concentration and surface area.
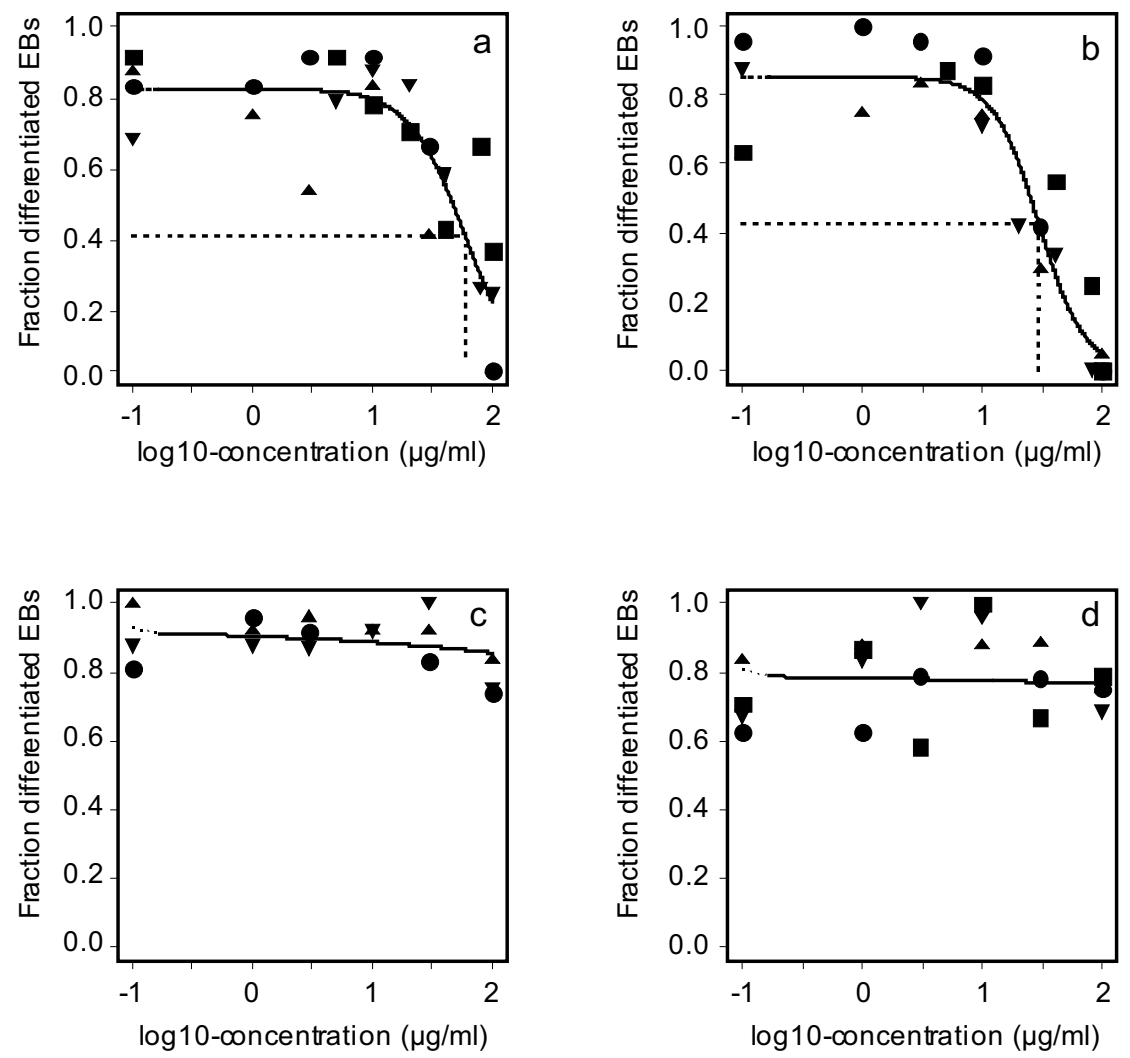

Figure 3.3 Dose-response curves of the fraction of embryoid bodies (EBs) differentiated into spontaneously contracting cardiomyocytes as a function of the nanoparticle concentration for $11 \mathrm{~nm}$ (a) 34A (b) 34B (c) and $248 \mathrm{~nm}$ (d) silica particles. Data was with a fitted log-logistic dose-response model: $y=a+(1-a) /(1+\exp (c$. $\ln (\mathrm{b} / \mathrm{x})))$. Dashed lines represent $\mathrm{ID}_{50}$ values of 59 and $29 \mu \mathrm{g} / \mathrm{ml}$ for $11 \mathrm{~nm}$ and 34A NPs, respectively. Different symbols represent different experiments. 


\subsubsection{Uptake in embryoid bodies}

Uptake of the $\mathrm{SiO}_{2}$ NPs was studied in cells of embryoid bodies at day 5 of the embryonic stem cell test by means of TEM. $\mathrm{SiO}_{2} \mathrm{NPs}$ of $248 \mathrm{~nm}$ were clearly visible inside vacuoles of the embryoid body (Figure 3.4). TEM tomography demonstrated that the $248 \mathrm{~nm}$ particles were indeed in the section and not on top or underneath. Vacuoles containing particles also appeared to be present in cells of embryoid bodies exposed to both $34 \mathrm{~nm}$ NPs, although the TEM images were less conclusive (images not shown). However, in view of the uptake of a large number of $248 \mathrm{~nm}$ particles it seems likely that also the smaller NPs were taken up by the cells. Possibly, the smaller $\mathrm{SiO}_{2}$ NPs were partially degraded in cellular vacuoles such as lysosomes or during the fixation procedure of the embryoid bodies for TEM. In general, the ability of transmission electron microscopy to detect small particles with relatively low electron density against the heterogeneous background of cells is limited compared to larger, more electron dense ENMs.



Figure 3.4 Transmission electron microscopy image of $248 \mathrm{~nm}$ particles in vacuoles of cells of embryoid bodies at day 5 of the embryonic stem cell test.

\subsubsection{Cytotoxicity after $\mathbf{2 4}$ hours and $\mathbf{1 0}$ days (WST-1)}

We investigated whether the observed embryotoxic effects of the $\mathrm{SiO}_{2} \mathrm{NPs}$ in this study were the direct result of cytotoxicity of the D3 cells caused by exposure to the NPs. Therefore, we assessed the effect of the $\mathrm{SiO}_{2}$ NPs on the metabolic activity of the D3 cells, a parameter commonly used to reflect cytotoxicity.

Microscopic evaluation of the D3 cells showed no major changes in cell morphology after $24 \mathrm{~h}$ exposure to $100 \mu \mathrm{g} / \mathrm{ml} \mathrm{SiO}_{2} \mathrm{NPs}$ as compared to unexposed D3 cells. Addition of $34 \mathrm{~B}$ and $248 \mathrm{~nm} \mathrm{SiO}{ }_{2} \mathrm{NPs}$ to the cell culture medium did not affect the metabolic activity of D3 cells after exposure for either $24 \mathrm{~h}$ or 10 days (Figure 3.5). However, the two $\mathrm{SiO}_{2}$ particles displaying developmental toxicity in the embryonic stem cell test (11 nm and 34 A) did modify the metabolic activity of the D3 cells. The effects observed were remarkably different between the two time points. Treatment with $11 \mathrm{~nm}$ and $34 \mathrm{~A} \mathrm{SiO}_{2} \mathrm{NPs}$ for $24 \mathrm{~h}$ 
significantly increased the metabolic activity of the D3 cells at concentrations starting from $1 \mu \mathrm{g} / \mathrm{ml}$. In contrast, when treatment was extended to 10 days, exposure to $100 \mu \mathrm{g} / \mathrm{ml}$ of the same particles caused a reduction in metabolic activity to $60 \%$ and $57 \%$ respectively compared to solvent control. This may be the result of a second burst of NPs being dispersed following the cell culture medium change after 3, 5 and 7 days, finally leading to toxic concentrations. The initial stimulation of metabolic activity after 24 hours of exposure may be an adaptive response of the cell to the NPs.

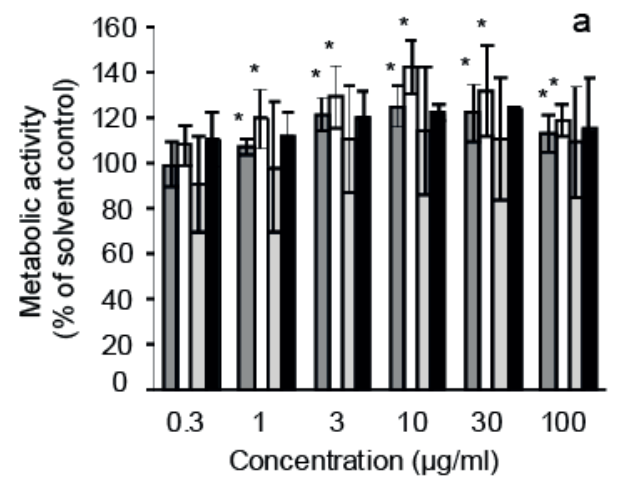

$\square 11 \mathrm{~nm} \quad \square 34 \mathrm{~A} \quad \square 34 \mathrm{~B}$

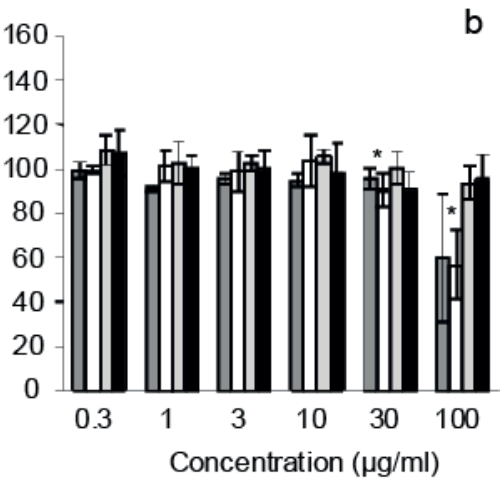

$\mathbf{Q} 248 \mathrm{~nm}$

Figure 3.5 Metabolic activity of D3 cells after $24 \mathrm{~h}(\mathrm{a})$ and 10 days (b) incubation with $0.3-100 \mu \mathrm{g} / \mathrm{ml}$ silica nanoparticles. Values given are mean \pm SD of three independent experiments. *Indicates a statistically significant difference compared to the solvent control $(p<0.05)$.

\subsection{DISCUSSION}

To date, a limited number of experimental studies have investigated the toxic effects of NPs in general during embryo development.The embryonic stem cell test is a formally validated test to predict the embryotoxic potential of chemicals (Genschow et al. 2004a; 2004b). Using this test for the first time on ENMs, we have demonstrated that $\mathrm{SiO}_{2} \mathrm{NPs}_{\mathrm{s}} 11$ $\mathrm{nm}$ and $34 \mathrm{~nm}$ inhibited differentiation of mouse embryonic stem cells into spontaneously contracting cardiomyocytes.

Amorphous $\mathrm{SiO}_{2}$ microparticles are biologically inert particles with numerous applications, and one could assume that nanoscale versions would also be biologically inert. However, the reduced scale may introduce new properties to the NPs and suggests that the safety of these materials may need to be re-assessed. Many studies on $\mathrm{SiO}_{2} \mathrm{NPs}_{\text {focus on their }}$ potential to induce cytotoxicity, oxidative stress and inflammation reactions (Chang et al. 2007; Lin et al. 2006; Lison et al. 2008). For example, Lin et al. showed dose-related effects of amorphous $\mathrm{SiO}_{2}$ NPs in human lung cancer cells, including reductions in cell viability, membrane damage, depletion of intracellular glutathione levels and enhanced generation 
of reactive oxygen species (Lin et al. 2006). Moreover, in vivo intratracheal instillation of amorphous $\mathrm{SiO}_{2}$ NPs resulted in transient inflammatory responses in the lungs of rats 24 $\mathrm{h}$ after exposure as evidenced by increased lactate dehydrogenase release and increased presence of neutrophils in the bronchial lavage fluid (Sayes et al. 2007). Experimental studies investigating the effects of $\mathrm{SiO}_{2} \mathrm{NPs}$ on the developing embryo are not available.

In the EST, two of the four tested $\mathrm{SiO}_{2}$ NPs inhibited the differentiation of embryonic stem cells into spontaneously contracting cardiomyocytes. The differentiation inhibiting effects were only observed for the $\mathrm{SiO}_{2}$ particles that were specified by the manufacturer to have nominal diameters of $10 \mathrm{~nm}$ and $30 \mathrm{~nm}$. SiO $\mathrm{NPs}_{2}$ with specified nominal diameters of 80 and $400 \mathrm{~nm}$ had no effect on either stem cell differentiation into cardiomyocytes or on the metabolic activity of the stem cells, despite the identical chemical compositions and production processes of the particles. In the absence of characterization data, one may have concluded that the toxicity of these NPs observed in this test system was related to the number of particles available to the cells or particle size. At equal mass per volume concentrations, the number of particles available to the cells is higher for small particles than for larger ones. In addition, compared to larger NPs, smaller NPs have a relatively larger surface area available to interact with the cells, proteins or other components essential for differentiation into cardiomyocytes.

However, particle characterization by means of TEM revealed that $\mathrm{SiO}_{2}$ particles that were specified as $400 \mathrm{~nm}$ were in effect $248 \mathrm{~nm}$. Moreover, the particles that were specified by the manufacturer to have nominal diameters of $30 \mathrm{~nm}$ and $80 \mathrm{~nm}$ were in effect of almost identical size, i.e. approximately $34 \mathrm{~nm}$. These results emphasize that characterizing the ENMs before use in biological studies is of utmost importance for correct interpretation of the data.

Electron microscopy of embryoid bodies at day 5 revealed internalized 400 (248) nm particles in vacuoles of the cells. Notwithstanding their bioavailability, these particles did not inhibit the differentiation of the stem cells. In addition, despite their identical primary size, only one of the $34 \mathrm{~nm}$ particles was cytotoxic and differentiation inhibiting in D3 cells. These results indicate that primary size is not the only factor determining the toxic properties of ENMs.

A main difference between the two ENMs consisting of $34 \mathrm{~nm}$ particles was the zetapotential. Of $34 \mathrm{~A} \mathrm{SiO}$, particles had a zetapotential of $-33.7 \mathrm{mV}$, while $34 \mathrm{~B} \mathrm{SiO}_{2}$ particles had a zetapotential of $-10.6 \mathrm{mV}$ (Table 3.1). It is well established that dispersions of NPs with zetapotentials between the range of -30 and $+30 \mathrm{mV}$ are less stable (Everett 1988), and this may explain the different behavior of the two $\mathrm{SiO}_{2}$ ENMs in D3 cell culture medium as a function of time. The DLS data show that shortly after dispersion in D3 cell culture medium, the amount of particles that are dispersed as free particles in the 10-100 $\mathrm{nm}$ size range appears to be higher for 34A than for 34B NPs. In addition, the interaction between particles and cell culture medium components appears to take place at a faster rate for 34A NPs compared to 34B NPs. 
An ongoing point of discussion is the most appropriate dose metric i.e. the unit of expressing the concentration of ENMs in toxicity assays. Although in most studies, concentrations are expressed in mass per volume, it has been suggested by several researchers that the number, volume or surface area of NPs determines the toxicity of ENMs (Di Pasqua et al. 2008; Duffin et al. 2007; Yamamoto et al. 2004). However, the mathematical conversion of mass concentration into particle number or surface area concentration assumes monodispersions of spherical particles. The DLS data of this study demonstrate that all particles are to some extent agglomerated/aggregated in cell culture medium, and the state of agglomeration/aggregation varies with different time points after dispersion. The relevant time point for determining the particle number or surface area concentration is unknown.

Even if monodispersions of spherical particles are assumed, it is often impossible to test the same particle number concentrations for all particles. For example, the particle number concentration of $11 \mathrm{~nm}$ particles resulting in a $50 \%$ inhibition of differentiation was $3.9 \times 10^{13}$ particles $/ \mathrm{ml}$. For the $248 \mathrm{~nm}$ particles, this particle number concentration equals a mass concentration of approximately $685 \mathrm{mg} / \mathrm{ml}$, which would unlikely be a stable dispersion.

To start investigating the mechanism underlying the inhibition of differentiation of the embryonic stem cell test by $\mathrm{SiO}_{2}$ NPs, the WST-1 cytotoxicity assay was performed in the embryonic stem cells at different time points. In the embryonic stem cell test, D3 cells were exposed to the $\mathrm{SiO}_{2} \mathrm{NPs}$ for 10 days. Using the same exposure period in the WST-1 test, the number of metabolically active D3 cells was markedly decreased after exposure to $11 \mathrm{~nm}$ and $34 \mathrm{~A} \mathrm{~nm}$ particles, but only at higher concentrations as compared to the exposure concentrations that impaired myocardial differentiation. The differentiation inhibiting effects of the $11 \mathrm{~nm}$ and $34 \mathrm{~A}$ particles were therefore, at least at the lower exposure concentrations, not due to a decrease in cell metabolic activity, but appeared to be specific effects on the differentiation of the D3 cells.

The interaction between $\mathrm{SiO}_{2}$ NPs and cell culture medium components may offer an alternative explanation for the inhibition of differentiation into myocardial cells. Several in vitro studies have confirmed that various NPs are able to adsorb serum proteins from tissue culture media, which affected the toxicity of the NPs (Barrett et al. 1999; Casey et al. 2008; Cedervall et al. 2007; Dutta et al. 2007). Results of one study even indicated that the reduced cell viability observed after exposure to carbon nanotubes was an indirect form of toxicity, caused by adsorption of nutrients to the ENMs which in turn lead to the depletion of the cell culture medium (Casey et al., 2008). The composition of the protein corona associated with the surface of polystyrene NPs was reported to depend on the size and surface charge of the particles (Lundqvist et al. 2008). In the present study, the DLS data reveal an interaction between the $\mathrm{SiO}_{2}$ particles and the $\mathrm{D} 3$ cell culture medium components. Further studies are needed for identification of the proteins associated with each type of $\mathrm{SiO}_{2}$ NPs. These studies may shed light on the pathways involved in the 
inhibition of differentiation observed for the $\mathrm{SiO}_{2} \mathrm{NPs}$. Experiments with well characterized NPs of other chemical compositions may determine whether the observed effects are specific for the $\mathrm{SiO}_{2} \mathrm{NPs}$, or whether other NPs exert the same effects.

In general, extrapolation of in vitro results to in vivo may be complex, even more so for NPs than for ordinary chemicals due to their intricate interaction with surrounding proteins and other components. Indeed, one study demonstrated that in vitro cytotoxicity of various NPs did not always correlate with in vivo results (Sayes et al. 2007). Therefore, the results of the embryonic stem cell test for the $\mathrm{SiO}_{2} \mathrm{NPs}$ have to be interpreted with caution until the underlying mechanism of toxicity is understood and in vivo data becomes available. More importantly, the observed potential embryotoxic effects of the $\mathrm{SiO}_{2} \mathrm{NPs}$ are only relevant if these particles are able to transfer from the mother to the fetus across the placenta, but information on this is currently lacking for $\mathrm{SiO}_{2} \mathrm{NPs}$ and contradicting for other ENMs.

In conclusion, inhibition of the differentiation of $\mathrm{D} 3$ cells by $\mathrm{SiO}_{2} \mathrm{NPs}$ was observed in the in vitro embryonic stem cell test. The four $\mathrm{SiO}_{2} \mathrm{NPs}$ demonstrated differences in cytotoxic and embryotoxic effects despite their identical chemical composition. Taken together, our results indicate that the widespread application of amorphous $\mathrm{SiO}_{2} \mathrm{NPs}$ may not be without any health hazards. Long term exposure of humans to high concentrations of these NPs could potentially result in particle accumulation and subsequently, induce acute or chronic toxicity. A relatively high systemic exposure to $\mathrm{SiO}_{2} \mathrm{NPs}$ might also be harmful to the embryo. Therefore, more research is warranted investigating the underlying mechanisms of these effects and the potential of these NPs to migrate into the uterus, placenta and embryo.

\section{ACKNOWLEDGMENT}

This work was funded by the EU FP6 project Nanolnteract (NMP4-CT-2006-033231). The authors thank Prof. Dr. Henk van Loveren for his valuable input during the preparation of this manuscript.

\section{CONFLICT OF INTEREST STATEMENT}

The authors declare that there are no conflicts of interest. 


\section{REFERENCES}

Barnes CA, Elsaesser A, Arkusz J, Smok A, Palus J, Lesniak A, Salvati A, Hanrahan JP, Jong WH, Dziubaltowska $E$ and others. 2008. Reproducible comet assay of amorphous silica nanoparticles detects no genotoxicity. Nano Lett 8(9):3069-74.

Barrett EG, Johnston C, Oberdorster G, Finkelstein JN. 1999. Silica binds serum proteins resulting in a shift of the dose-response for silica-induced chemokine expression in an alveolar type II cell line. Toxicol Appl Pharmacol 161(2):111-22.

Bharali DJ, Klejbor I, Stachowiak EK, Dutta P, Roy I, Kaur N, Bergey EJ, Prasad PN, Stachowiak MK. 2005. Organically modified silica nanoparticles: a nonviral vector for in vivo gene delivery and expression in the brain. Proc Natl Acad Sci U S A 102(32):11539-44.

Bosman SJ, Nieto SP, Patton WC, Jacobson JD, Corselli JU, Chan PJ. 2005. Development of mammalian embryos exposed to mixed-size nanoparticles. Clin Exp Obstet Gynecol 32(4):222-4.

Casey A, Herzog E, Lyng FM, Byrne HJ, Chambers G, Davoren M. 2008. Single walled carbon nanotubes induce indirect cytotoxicity by medium depletion in A549 lung cells. Toxicol Lett 179(2):78-84.

Cedervall T, Lynch I, Foy M, Berggard T, Donnelly SC, Cagney G, Linse S, Dawson KA. 2007. Detailed identification of plasma proteins adsorbed on copolymer nanoparticles. Angew Chem Int Ed Engl 46(30):5754-6.

Challier JC, Panigel M, Meyer E. 1973. Uptake of colloidal 198Au by fetal liver in rat, after direct intrafetal administration. Int J Nucl Med Biol 1(2):103-6.

Chang JS, Chang KL, Hwang DF, Kong ZL. 2007. In vitro cytotoxicitiy of silica nanoparticles at high concentrations strongly depends on the metabolic activity type of the cell line. Environ Sci Technol 41(6):2064-8.

De Jong WH, Borm PJ. 2008. Drug delivery and nanoparticles:applications and hazards. Int J Nanomedicine 3(2):133-49.

Di Pasqua AJ, Sharma KK, Shi YL, Toms BB, Ouellette W, Dabrowiak JC, Asefa T. 2008. Cytotoxicity of mesoporous silica nanomaterials. J Inorg Biochem 102(7):1416-23.

Duffin R, Tran L, Brown D, Stone V, Donaldson K. 2007. Proinflammogenic effects of low-toxicity and metal nanoparticles in vivo and in vitro: highlighting the role of particle surface area and surface reactivity. Inhal Toxicol 19(10):849-56.

Dutta D, Sundaram SK, Teeguarden JG, Riley BJ, Fifield LS, Jacobs JM, Addleman SR, Kaysen GA, Moudgil BM, Weber TJ. 2007. Adsorbed proteins influence the biological activity and molecular targeting of nanomaterials. Toxicol Sci 100(1):303-15.

Everett DH. 1988. How are colloidal dispersions destroyed? I Aggregation Processes. Basic principles of colloid science. London: The Royal Society of Chemistry.

Genschow E, Seiler A, Spielman H. 2004a. Considering the test performance of three class data using linear discriminant analysis. Altern Lab Anim 32:713-23.

Genschow E, Spielmann H, Scholz G, Pohl I, Seiler A, Clemann N, Bremer S, Becker K. 2004 b. Validation of the embryonic stem cell test in the international ECVAM validation study on three in vitro embryotoxicity tests. Altern Lab Anim 32(3):209-44.

Hirsch LR, Stafford RJ, Bankson JA, Sershen SR, Rivera B, Price RE, Hazle JD, Halas NJ, West JL. 2003. Nanoshell-mediated near-infrared thermal therapy of tumors under magnetic resonance guidance. Proc Natl Acad Sci U S A 100(23):13549-54. 
Kwon JT, Hwang SK, Jin H, Kim DS, Minai-Tehrani A, Yoon HJ, Choi M, Yoon TJ, Han DY, Kang YW and others. 2008. Body distribution of inhaled fluorescent magnetic nanoparticles in the mice. J Occup Health 50(1):1-6.

Lin W, Huang YW, Zhou XD, Ma Y. 2006. In vitro toxicity of silica nanoparticles in human lung cancer cells. Toxicol Appl Pharmacol 217(3):252-9.

Lison D, Thomassen LC, Rabolli V, Gonzalez L, Napierska D, Seo JW, Kirsch-Volders M, Hoet P, Kirschhock CE, Martens JA. 2008. Nominal and effective dosimetry of silica nanoparticles in cytotoxicity assays. Toxicol Sci 104(1):155-62.

Lundqvist M, Stigler J, Elia G, Lynch I, Cedervall T, Dawson KA. 2008. Nanoparticle size and surface properties determine the protein corona with possible implications for biological impacts. Proc Natl Acad Sci U S A 105(38):14265-70.

Murdock RC, Braydich-Stolle L, Schrand AM, Schlager JJ, Hussain SM. 2008. Characterization of nanomaterial dispersion in solution prior to in vitro exposure using dynamic light scattering technique. Toxicol Sci 101(2):239-253.

Nel A, Xia T, Madler L, Li N. 2006. Toxic potential of materials at the nanolevel. Science 311(5761):6227.

Oberdorster G, Maynard A, Donaldson K, Castranova V, Fitzpatrick J, Ausman K, Carter J, Karn B, Kreyling $W$, Lai $D$ and others. 2005. Principles for characterizing the potential human health effects from exposure to nanomaterials: elements of a screening strategy. Part Fibre Toxicol 2:8.

Park MVDZ, Lankveld DPK, van Loveren H, de Jong W. 2009. The status of in vitro toxicity studies in risk assessment of nanomaterials Nanomedicine 4(6):669-685.

Qhobosheane M, Santra S, Zhang P, Tan W. 2001. Biochemically functionalized silica nanoparticles. Analyst 126(8):1274-8.

Renn O, Roco MC. 2006. Nanotechnology and the need for risk governance. Journal of nanoparticle research 8:153-191.

Sadauskas E, Wallin H, Stoltenberg M, Vogel U, Doering P, Larsen A, Danscher G. 2007. Kupffer cells are central in the removal of nanoparticles from the organism. Part Fibre Toxicol 4:10.

Santra S, Zhang P, Wang K, Tapec R, Tan W. 2001. Conjugation of biomolecules with luminophoredoped silica nanoparticles for photostable biomarkers. Anal Chem 73(20):4988-93.

Sayes CM, Reed KL, Warheit DB. 2007. Assessing toxicity of fine and nanoparticles: comparing in vitro measurements to in vivo pulmonary toxicity profiles. Toxicol Sci 97(1):163-80.

Scholz G, Spielman H. 2000. Embryonic Stem Cell Test (EST). INVITTOX no113:1-33.

Semmler-Behnke M, Kreyling WG, Lipka J, Fertsch S, Wenk A, Takenaka S, Schmid G, Brandau W. 2008. Biodistribution of 1.4- and 18-nm gold particles in rats. Small 4(12):2108-11.

Semmler M, Seitz J, Erbe F, Mayer P, Heyder J, Oberdorster G, Kreyling WG. 2004. Long-term clearance kinetics of inhaled ultrafine insoluble iridium particles from the rat lung, including transient translocation into secondary organs. Inhal Toxicol 16(6-7):453-9.

Service RF. 2008. Nanotechnology. Can high-speed tests sort out which nanomaterials are safe? Science 321(5892):1036-7.

Shaw SY, Westly EC, Pittet MJ, Subramanian A, Schreiber SL, Weissleder R. 2008. Perturbational profiling of nanomaterial biologic activity. Proc Natl Acad Sci U S A 105(21):7387-92.

Slob W. 2002. Dose-response modeling of continuous endpoints. Toxicol Sci 66(2):298-312.

Stöber W, Fink A, Bohn E. 1968. Controlled growth of monodisperse silica spheres in the micron size range. J. Colloid Interface Sci. 26(1):62-9. 
Takahashi S, Matsuoka O. 1981. Cross placental transfer of 198Au-colloid in near term rats. J Radiat Res (Tokyo) 22(2):242-9.

Tsuchiya T, Oguri I, Yamakoshi YN, Miyata N. 1996. Novel harmful effects of [60]fullerene on mouse embryos in vitro and in vivo. FEBS Lett 393(1):139-45.

Usenko CY, Harper SL, Tanguay RL. 2008. Fullerene C(60) exposure elicits an oxidative stress response in embryonic zebrafish. Toxicol Appl Pharmacol 229(1):44-55.

Warheit DB. 2008. How meaningful are the results of nanotoxicity studies in the absence of adequate material characterization. Toxicol Sci 101(2):183-185.

Woodrow Wilson International Center for Scholars. 2008. An inventory of nanotechnology-based consumer products currently on the market.

Yamamoto A, Honma R, Sumita M, Hanawa T. 2004. Cytotoxicity evaluation of ceramic particles of different sizes and shapes. J Biomed Mater Res A 68(2):244-56.

Zhang FF, Wan Q, Li CX, Wang XL, Zhu ZQ, Xian YZ, Jin LT, Yamamoto K. 2004. Simultaneous assay of glucose, lactate, L-glutamate and hypoxanthine levels in a rat striatum using enzyme electrodes based on neutral red-doped silica nanoparticles. Anal Bioanal Chem 380(4):637-42.

Zhu X, Zhu L, Li Y, Duan Z, Chen W, Alvarez PJ. 2007. Developmental toxicity in zebrafish (Danio rerio) embryos after exposure to manufactured nanomaterials: buckminsterfullerene aggregates $\left(\mathrm{nC}_{60}\right.$ ) and fullerol. Environ Toxicol Chem 26(5):976-9. 



\section{CHAPTER 4}

\section{GENOTOXICITY EVALUATION OF AMORPHOUS SILICA NANOPARTICLES OF DIFFERENT SIZES USING THE MICRONUCLEUS AND THE PLASMID lacZ GENE MUTATION ASSAY}



${ }^{1}$ Laboratory for Health Protection Research, National Institute for Public Health and the Environment, 3720 BA, Bilthoven, the Netherlands

${ }^{2}$ Department of Health Risk Analysis and Toxicology, Maastricht University, 6200 MD Maastricht, The Netherlands

${ }^{3}$ Centre for Molecular Bioscience, University of Ulster, Coleraine, BT52 1SA, United Kingdom ${ }^{4}$ Centre for BioNano Interactions, School of Chemistry and Chemical Biology, University College Dublin, Belfield, Dublin 4, Ireland 



\section{ABSTRACT}

We investigated the potential of four well-characterized amorphous silica nanoparticles to induce chromosomal aberrations and gene mutations using two in vitro genotoxicity assays. Transmission electron microscopy (TEM) was used to verify the manufacturer's nominal size of 10, 30, 80 and $400 \mathrm{~nm}$ which showed actual sizes of 11, 34, 34 and 248 $\mathrm{nm}$, respectively. Both $34 \mathrm{~nm}$ silica nanoparticles ( $A$ and $B$ ) induced gene mutations in mouse embryonic fibroblasts carrying the lacZ reporter gene and the $34 \mathrm{~B}$ silica nanoparticles induced chromosomal aberrations in the micronucleus assay using 3T3-L1 mouse fibroblasts. TEM imaging demonstrated that the majority of nanoparticles were localized in vacuoles and not in the nucleus of 3T3-L1 cells, indicating that the observed DNA damage was most likely a result of indirect mechanisms. Further studies are needed to reveal these mechanisms and to determine the biological relevance of the effects of these particular silica nanoparticles in vivo.

\subsection{INTRODUCTION}

The element silicon ( $\mathrm{Si}$ ) mainly exists as silicon dioxide ( ilica, $\mathrm{SiO}_{2}$ ) with either amorphous or crystalline molecular structures (Figure 4.1). As the main component of sand and rocks, silica is one of the most abundant materials on earth (Merget et al. 2002). Amorphous silica can be synthetically produced and has a wide commercial use in various applications. Amorphous silica products such as gels and sols (colloidal suspensions) are manufactured for applications such as food additives and microelectronics (Barik et al. 2008). Due to its relative biocompatibility, silica has also been used in the formulation of artificial implants (Areva et al. 2007).

Figure 4.1 Structural representation of crystalline (a) and amorphous (b) silica.
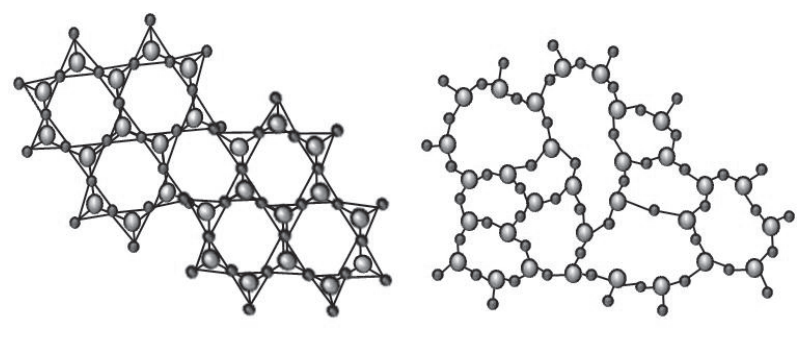

Since the development of nanotechnology, the nanoform of $\mathrm{SiO}_{2}$ materials has gained interest for a wide variety of applications. Surface charge modified hydrophobic amorphous $\mathrm{SiO}_{2}$ NPs have qualified for approval as a novel form of nanobiopesticides for horticultural and crop plants (Barik et al. 2008). $\mathrm{SiO}_{2}$ ENMs are in the top five of ENMs explicitly referenced in nanotechnology consumer products, mostly in sporting goods and 
cosmetics (Hansen et al. 2008; Woodrow Wilson International Center for Scholars 2009). Their inert nature and small size make $\mathrm{SiO}_{2}$ ENMs particularly useful to the pharmaceutical industry as drug carriers, bio-imaging agents and gene transfection vectors (Barik et al. 2008; Bharali et al. 2005; Gemeinhart et al. 2005; Santra et al. 2004; Slowing et al. 2008; Trewyn et al. 2007). The diversity of these applications can be anticipated to result in an increased level of exposure to a heterogeneous mixture consisting of $\mathrm{SiO}_{2} \mathrm{NPs}$ differing in size, structure, specific surface area, shape, charge and other properties. Several of these characteristics have been claimed to play a role in determining the toxic effects of NPs, particularly size and surface area, but there appears to be no consensus (Duffin et al. 2007; Hamoir et al. 2003; Limbach et al. 2005; Monteiller et al. 2007; Yang et al. 2009). As a consequence of not knowing which NP properties may play a role in eliciting toxic effects, regulatory frameworks are contemplating whether the safety of all these different types of NPs should be evaluated separately, or whether extrapolation of safety data from one type to another is possible. In view of the existing uncertainty a case by case approach is advocated (SCENIHR 2009).

Our current research is focused on investigating whether NP size might be one of those properties determining the toxicity of amorphous $\mathrm{SiO}_{2} \mathrm{NPs}$. We have previously evaluated four well-characterized amorphous $\mathrm{SiO}_{2} \mathrm{NPs}$ of the same source in the embryonic stem cell differentiation assay (Park et al. 2009a). This assay is validated as an in vitro developmental toxicity test discriminating between chemicals in three classes of embryotoxicity (Genschow et al. 2004). While $\mathrm{SiO}_{2}$ NPs of $11 \mathrm{~nm}$ inhibited the differentiation of embryonic stem cells into contracting cardiomyocytes, those of $248 \mathrm{~nm}$ elicited no effect. In addition, this study included two $\mathrm{SiO}_{2}$ NPs of $34 \mathrm{~nm}$ with different zetapotentials ( $A$ and $B$ ), and only one of these (34A) inhibited the differentiation of embryonic stem cells into contracting cardiomyocytes, indicating that factors other than NP size contributed to the biological effects in this assay.

We have now evaluated the potential size-related effects of these same $\mathrm{SiO}_{2} \mathrm{NPs}$ in a series of genotoxicity studies. We have previously reported that none of these $\mathrm{SiO}_{2} \mathrm{NPs}$ elicited a response in the single cell gel electrophoresis (comet) assay using 3T3-L1 mouse fibroblasts, performed by two independent laboratories (Barnes et al. 2008). This indicator test is commonly used to assess whether chemicals induce single- or double- strand DNA breaks, which may or may not be reversible.

In the current study, we further investigated the genotoxic potential of these $\mathrm{SiO}_{2} \mathrm{NPs}$ by performing two genotoxicity assays which are commonly used in regulatory frameworks to measure chromosomal aberrations and gene mutations; both irreversible genotoxic endpoints. The micronucleus assay detects chromosomal aberrations and was performed in 3T3-L1 mouse fibroblasts, while gene mutations were measured in mouse embryonic fibroblasts isolated from pU288 plasmid LacZ mice, containing lacZ as a reporter gene (MEF-lacZ). To our knowledge, these two assays have not previously been applied to test whether amorphous $\mathrm{SiO}_{2}$ NPs induce genotoxic effects. 


\subsection{MATERIALS AND METHODS}

\subsubsection{Silica nanoparticles}

The spherical amorphous $\mathrm{SiO}_{2}$ NPs used in this study were obtained from Glantreo, Ltd., Cork, Ireland. The particles were synthesized via the Stöber method without any stabilizer (Stöber et al. 1968). To avoid potential interference from synthesis residues and solvents, NPs were dialyzed extensively against a very large excess of pure MilliQ water. The obtained NP stock solutions tested negative for the presence of endotoxin and bacterial or fungal infection, as determined by the Limulus Amoebocyte Lysate (Gel-clot) assay and inoculation on Columbia sheep blood agar plates (Oxoid Ltd), respectively (data not shown).

\begin{tabular}{llll}
$\begin{array}{l}\text { NP size } \\
{[\mathrm{nm}]}\end{array}$ & $\begin{array}{l}\text { zeta potential } \zeta \\
{[\mathrm{mV}]}\end{array}$ & $\begin{array}{l}\text { Hydrodynamic size }^{\mathrm{b}} \\
{[\mathrm{nm}]}\end{array}$ & PDI $^{c}$ \\
\hline $11.0(2.2)$ & $-43.3(11.8)$ & $103.1(1.9)$ & $0.792(0.011)$ \\
$33.7(4.0)$ & $-33.7(3.0)$ & $77.9(1.1)$ & $0.259(0.094)$ \\
$33.7(6.1)$ & $-10.6(0.9)$ & $65.9(1.7)$ & $0.374(0.068)$ \\
$247.9(24.1)$ & $-49.1(0.5)$ & $269.0(7.1)$ & $0.049(0.020)$ \\
\hline
\end{tabular}

Values given are mean (standard deviation). 'As measured by Transmission Electron Microscopy, average of at least 100 nanoparticles ${ }^{b}$ As measured by Dynamic Light Scattering, average of at

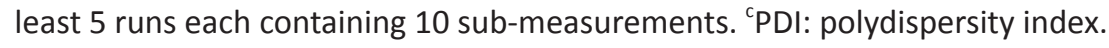

Table 4.1 Characterization of silica nanoparticles shortly after dispersion in deionized water.

Primary size of the four tested $\mathrm{SiO}_{2}$ NPs was determined by means of TEM. Hydrodynamic size by means of DLS and the zetapotential in deionized water were determined with the Malvern $3000 \mathrm{HS}$ Zetasizer photon correlation spectrophotometer (Table 4.1). TEM measurements revealed that the diameters of the particles were $11 \mathrm{~nm}, 34 \mathrm{~nm}, 34 \mathrm{~nm}$ and $248 \mathrm{~nm}$, respectively. The two $34 \mathrm{~nm}$ particles had significantly different zeta-potentials, so both materials were included in the assays. Furthermore, the polydispersity index and dynamic light scattering measurements revealed that the $11 \mathrm{~nm} \mathrm{SiO}{ }_{2} \mathrm{NPs}$ were highly aggregated in distilled water.More details on the characterization methods have been described earlier (Barnes et al. 2008).

Shortly before the start of each experiment, $\mathrm{SiO}_{2} \mathrm{NPs}$ were thoroughly vortexed (20s at $1500 / \mathrm{min}$ ), diluted in distilled water and dispersed in the same cell culture medium used to routinely culture the cells, i.e. containing $10 \%$ Fetal Calf Serum.

\subsubsection{Cell culture}

The mouse embryonic fibroblast cell line 3T3-L1 was obtained from the Nofer Institute of Occupational Medicine, Lodz, Poland, and was the same cell line used for the comet assay published previously (Barnes et al. 2008). The 3T3-L1 cell line is derived from a Swiss 
albino mouse and to the best of our knowledge this cell line has not been genetically modified. Therefore we expect the 3T3-L1 cell to have a normal genetic background and to be genetically stable.

Cells were routinely cultured at $37^{\circ} \mathrm{C}$ and $5 \% \mathrm{CO}_{2}$ in DMEM, high glucose with glutamax (Gibco 61965-059) supplemented with 10\% FCS (Gibco 16010-159), 1\% Penicillin-Streptomycin solution (10000 U/mL / $10000 \mathrm{\mu g} / \mathrm{mL}$, Gibco 15140), and 1\% NEAA (Gibco 11140).

Mouse embryonic fibroblasts (MEF-LacZ) were isolated from 13.5 day old embryos from transgenic C57BL/6 mice containing multiple copies of the pUR288 plasmid with the bacterial lacZ gene as a reporter gene in their genome, as described previously (Mahabir et al. 2009). Aliquots of $3 \times 10^{6}$ cells in $1 \mathrm{ml}$ cell culture medium were kept at $-80{ }^{\circ} \mathrm{C}$ for at least $24 \mathrm{~h}$ and were then stored in liquid nitrogen. Before the start of the experiment, cells were thawed and cultured for one week in $175 \mathrm{~cm}^{2}$ flasks at $37{ }^{\circ} \mathrm{C}$ under $10 \% \mathrm{CO}_{2}$ and $3 \% \mathrm{O}_{2}$, undergoing 1 passage. The cell culture medium used for both cell culture and experiments with MEF-LacZ consisted of DMEM (Gibco 31885) supplemented with 1\% Modified Eagles Medium NEAA (Gibco 11140), 2\% Penicillin-Streptomycin (Gibco 15070) and $10 \%$ Fetal Bovine Serum (FBS, Biocell).

\subsubsection{Cytotoxicity in MEF-LacZ}

The effect of the $\mathrm{SiO}_{2} \mathrm{NPs}$ on the metabolic activity of the MEF-LacZ cells after $24 \mathrm{~h}$ exposure to $\mathrm{SiO}_{2}$ NPs was evaluated using the WST-1 cytotoxicity assay. Cells were seeded in 96-well tissue grade microtiter plates at a density of $5-8 \times 10^{3}$ and cultured for $24 \mathrm{~h}$ in a humidified atmosphere at $37{ }^{\circ} \mathrm{C}, 10 \% \mathrm{CO}_{2}$ and $3 \% \mathrm{O}_{2}$. The following day, cells were exposed to $\mathrm{SiO}_{2}$ NPs in cell culture medium containing $10 \%$ FCS at concentrations ranging from 0.3 to 100 $\mathrm{\mu g} / \mathrm{ml} \mathrm{SiO}_{2} \mathrm{NPs}$ in triplicate wells. In each cytotoxicity experiment, cells exposed to $10 \%$ distilled water or $5 \%$ DMSO served as solvent and positive controls, respectively. After $24 \mathrm{~h}$ exposure, cells were incubated with $10 \mu \mathrm{l}$ Cell Proliferation Reagent WST-1 (Roche, Almere, The Netherlands) at $37^{\circ} \mathrm{C}$ for $3 \mathrm{~h}$. The absorbance of the wells was measured using a SpectraMax ${ }^{\circledR} 190$ scanning multiwell spectrophotometer (Molecular Devices, Sunnyvale, USA) at a wavelength of $440 \mathrm{~nm}$. Data were acquired using SoftMax Pro 5 software (Molecular Devices, Sunnyvale, USA). Interference of the $\mathrm{SiO}_{2}$ NPs with the WST1 assay was experimentally excluded, as reported previously (Park et al. 2009a). At least three independent experiments were performed.

\subsubsection{Nanoparticle uptake in 3T3-L1 fibroblasts}

To study the uptake of $\mathrm{SiO}_{2}$ NPs in 3T3-L1 fibroblasts, cells were seeded into $25 \mathrm{~cm}^{2}$ cell culture flasks at a density of $1-2 \times 10^{5} \mathrm{cell} / \mathrm{cm}^{2}$ and allowed to grow for $24 \mathrm{~h}\left(37^{\circ} \mathrm{C}, 5 \%\right.$ $\left.\mathrm{CO}_{2}\right)$. Subsequently, cells were exposed for $16 \mathrm{~h}$ to $\mathrm{SiO}_{2}$ particles in cell culture medium containing $10 \%$ FCS at a concentration of $50 \mu \mathrm{g} / \mathrm{ml}$. Control samples were not exposed to NPs. After incubation with NPs the cells were dislodged and centrifuged into a pellet. The pellet was chemically fixed with a pre-warmed combination of $2.5 \%$ glutaraldehyde 
and $2 \%$ formaldehyde prepared in $0.1 \mathrm{M}$ sodium cacodylate buffer before post-fixation in $1 \%$ aq osmium tetroxide (Agar Scientific). The cells were rinsed with PBS and subsequently dehydrated in a graded ethanol series. The samples were then infiltrated in increasing proportions of Low Viscosity Spurr resin (SPI Supplies) and were allowed to polymerise at $70{ }^{\circ} \mathrm{C}$ for $24 \mathrm{~h}$. After polymerisation of the resin block, $100 \mathrm{~nm}$ to $300 \mathrm{~nm}$ sections (depending on the NPs size) were cut with a diamond knife (Diatome) using an ultramicrotome (PowerTome XL, RMC). The sections were transferred onto standard TEM grids and imaged in a Transmission Electron Microscope (Tecnai $\mathrm{G}^{2}$ Spirit, FEI).

\subsubsection{In vitro micronucleus test in 3T3-L1 fibroblasts}

The in vitro micronucleus test is commonly used to evaluate whether chemicals have the potential to induce chromosomal aberrations consisting of clastogenic (chromosome breaks) or aneugenic (chromosome loss) effects. During mitosis, these chromosomes or chromosome fragments become separated from the nucleus in nuclear envelopes, which are visible as micronuclei (MN) in the cell. Exposure of the cells to the cytokinesis blocking agent cytochalasin $B$ enables the identification of $\mathrm{MN}$ in binucleated cells, representing chromosomal damage. In addition, the percentage of cytostasis based on the cytokinesis block proliferation index (CBPI) represents a measure of cytotoxicity resulting from the treatment.

Approximately $1 \times 10^{6} 3 T 3-\mathrm{L} 1$ cells were seeded in a volume of $5 \mathrm{ml}$ cell culture medium in a $25 \mathrm{~cm}^{2}$ tissue culture flask. The cells were incubated for $24 \mathrm{~h}$ at $37^{\circ} \mathrm{C}$ under $5 \% \mathrm{CO}_{2}$ to form a semi confluent monolayer. Before treatment with NPs, cells were washed once with Dulbecco's phosphate-buffered saline, containing $\mathrm{KCl}, \mathrm{KH}_{2} \mathrm{PO}_{4}, \mathrm{NaCl}, \mathrm{Na}_{2} \mathrm{HPO}_{4}$ without calcium or magnesium (DPBS). Cytochalasin $\mathrm{B}(6 \mu \mathrm{g} / \mathrm{ml})$ and $\mathrm{SiO}_{2} \mathrm{NPs}$ in cell culture medium containing $10 \%$ FCS were added simultaneously for $24 \mathrm{~h}$ at final concentrations of 4,40 or $400 \mu \mathrm{g} / \mathrm{ml}$ in single cultures. The cell and NP test concentrations 4 and $40 \mu \mathrm{g} /$ $\mathrm{ml}$ are the same as the concentrations used in the comet assay published earlier (Barnes et al. 2008). We also included an extra concentration of $400 \mu \mathrm{g} / \mathrm{ml}$ to enable testing up to cytotoxic concentrations. Cells treated with distilled water and cytochalasin B served as a negative control. Bleomycin (BLM) was included as a positive control clastogen at a final concentration of $2 \mu \mathrm{g} / \mathrm{ml}$. Cells were incubated for 1.5 cell cycles, i.e. $24 \mathrm{~h}$.

After treatment, cells were harvested with trypsin (0.5\%) and transferred to $15 \mathrm{ml}$ vials. Cytospin preparations ( $5 \mathrm{~min}$ at $500 \mathrm{rpm}$ ) were made using a Cytospin 3 (Thermo Shandon Limited, U.K.). The optimal cell volume for the cytospin was determined based on the cell density of a number of test slides, and was generally $100 \mu \mathrm{l}$. After drying, the slides were fixed with methanol (70\%) for 5 minutes and stained for approximately 20 min with a $6 \%$ Giemsa solution.

For a reliable measurement, $\mathrm{MN}$ were scored in at least 1000 binucleated cells for every treatment. Results were obtained from three independent experiments. Simultaneously, the effect of a treatment on cell division was measured by assessing the percentage cytostasis scored in at least 2000 cells per treatment. 
The percentage cytostasis was calculated as:

$$
100-100 \times \frac{\left(C B P I_{\text {treated }}-1\right)}{\left(C B P I_{\text {control }}-1\right)}
$$

Where:

$$
C B P I=\frac{([\# \text { mononucleates }]+[2 \mathrm{x} \# \text { binucleates }]+[3 \mathrm{x} \# \text { multinucleates }])}{\# \text { cells } s_{\text {total }}}
$$

\subsubsection{LacZ gene mutation test in MEF-LacZ cells}

In vitro gene mutation tests in mammalian cells are routinely used to detect gene mutations induced by chemicals. For the current experiments, embryonic fibroblasts isolated from pU288 plasmid LacZ mice were used because they contain multiple copies of the pUR288 plasmid with the bacterial lacZ gene as a reporter gene in their genome. The advantage of using these particular cells compared to other commonly used cells is that they are capable of detecting various mutagenic events, including point mutations and deletions induced by chemicals (Mahabir et al. 2009). After exposure of the cells to the test substance $\left(\mathrm{SiO}_{2}\right.$ NPs in this case), plasmids are isolated from the genome and transfected into Escherichia coli (E. coli) C ( $\triangle / a c Z /$ galE ) cells (Figure 4.2). The E. coli cells are plated onto both a nonselective and a mutant selective plate. The non-selective plate contains 5-bromo-4-chloro3-indolyl-ß-D-galactopyranoside (X-gal) and is used to determine overall plasmid rescue efficiency. Blue colonies are formed when X-gal is metabolized by ß-galactosidase present in cells containing an intact lacZ product from the transfected plasmid. The selective plate contains phenyl-ß-D-galactopyranoside (P-gal), which is toxic to the cells when metabolized by ß-galactosidase and subsequent enzymes. The colonies growing on the selective plate result from cells carrying a plasmid with a mutation in the lacZ gene, which hampers ß-galactosidase activity (Dollé et al. 1996).

MEF-lacZ cells were seeded in $10 \mathrm{~cm}$ petri dishes containing $1 \times 10^{6}$ cells and a final volume of $5 \mathrm{ml}$ cell culture medium. The cells were incubated for 24 hours at $37^{\circ} \mathrm{C}$ under $10 \% \mathrm{CO}_{2}$ and $3 \% \mathrm{O}_{2}$. Subsequently, the cells were washed once with DPBS and fresh cell culture medium containing $10 \% \mathrm{FCS}$ and $\mathrm{SiO}_{2}$ NPs at concentrations ranging from 4 to $400 \mathrm{\mu g} / \mathrm{ml}$ was added in duplicate cultures per experiment. Distilled water was used as a vehicle control and $\mathrm{N}$-nitroso- $\mathrm{N}$-methylurea (MNU) as a positive control. After $16 \mathrm{~h}$ treatment, cells were collected in $1 \mathrm{ml}$ phosphate buffered saline (PBS) using a cell scraper. The cell suspension was centrifuged at $1200 \mathrm{rpm}$ and $4{ }^{\circ} \mathrm{C}$ for $5 \mathrm{~min}$ and the pellet was stored at $-20^{\circ} \mathrm{C}$ until the lacZ plasmid rescue assay was performed.

The lacZ plasmid rescue and determination of the mutant frequency was performed as described previously (Dollé et al. 1996). Briefly, total genomic DNA containing (parts of) 
the lacZ gene was isolated from the cells using phenol extraction, followed by digestion with the restriction enzyme HindIII. The lacZ containing plasmids were rescued from the digest using magnetic beads coated with the lacZ/lacl fusion protein. After elution from the beads, the plasmids were transfected into an electrocompetent $E$. coli strain $C$ ( $\Delta$ lacZ /galE-). Small fractions of the bacterial samples (dilution factor 200,400 or 1000) were incubated on non-selective $X$-galactosidase plates to determine the plasmid rescue efficiency. The remainder was incubated on selective P-glycosidase plates to select for mutants. The lac $Z$ mutant frequency was calculated by dividing the number of mutants by the total number of rescued colonies $\times$ dilution factor. Results were obtained from at least three independent experiments.

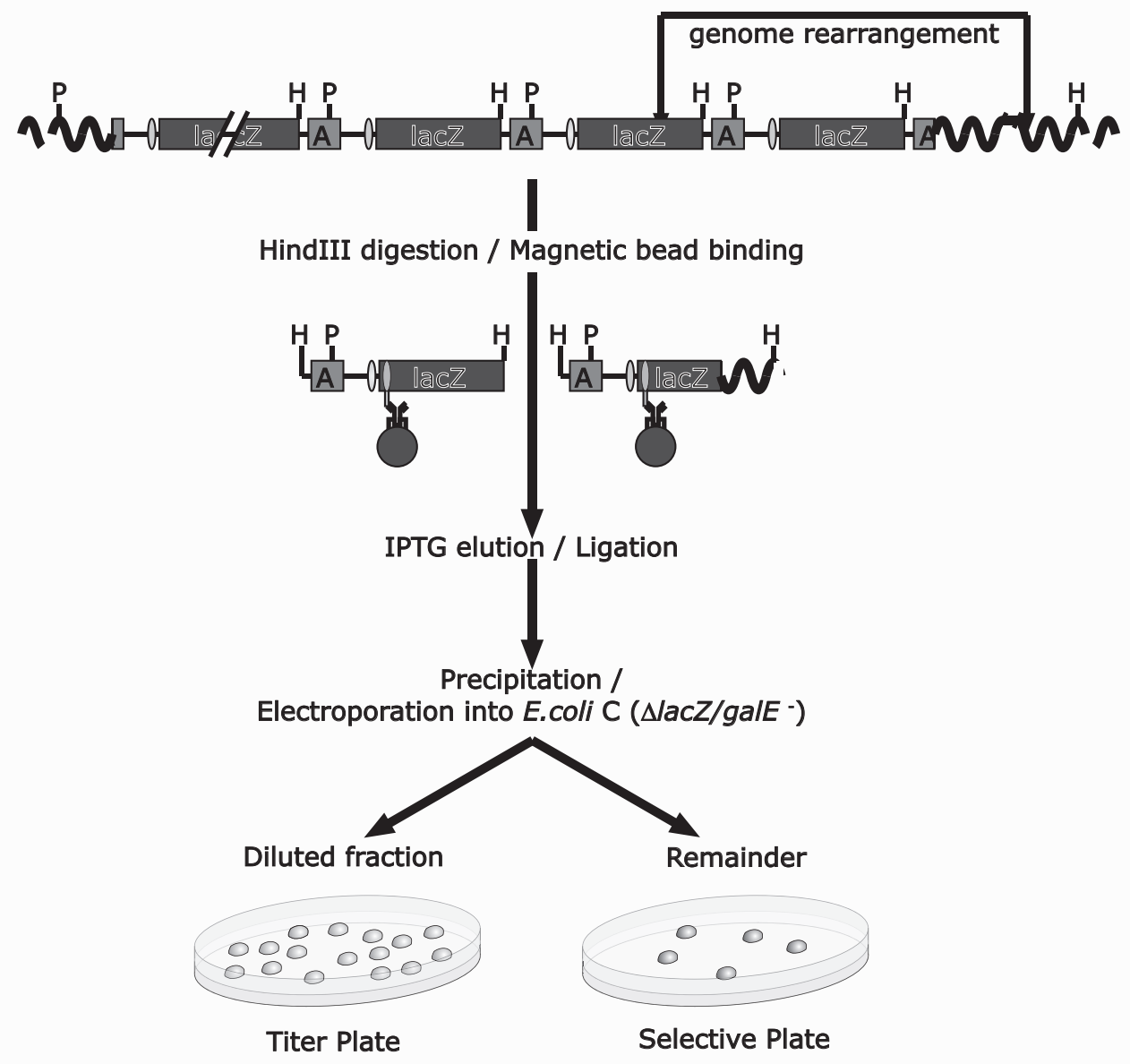

Figure 4.2 Schematic representation of the plasmid LacZ gene mutation assay. 


\subsubsection{Acellular redox activity of silica nanoparticles}

The acellular redox activity of the NPs was evaluated using the dithiothreitol (DTT) assay. The DTT assay determines the general redox activity of a sample by measuring the stimulus $\left(\mathrm{SiO}_{2} \mathrm{NPS}\right.$ in this case) dependent oxidation of DTT, a dithiol. The assay measures the formation of reactive oxygen species (ROS) by a known amount of DTT. During this reaction, DTT is consumed, followed by its reaction with 5,5'-dithiobis-(2-) nitrobenzoic acid (DTNB) to form 2-nitro-5-mercaptobenzoic acid which can be measured by a spectrophotometer.

$\mathrm{SiO}_{2} \mathrm{NPs}(10 \mu \mathrm{g})$ were incubated with $100 \mathrm{nM}$ DTT in a $0.5 \mathrm{M}$ potassium phosphate buffer at $\mathrm{pH} 7.4$ for $0,15,30$ or 45 minutes at $37^{\circ} \mathrm{C}$ with a total volume of $1 \mathrm{ml}$ per time-aliquot and transferred to an equal volume of cold $10 \%$ trichloroacetic acid solution after the indicated incubation time. Aliquots were transferred to $1 \mathrm{ml} 0.4 \mathrm{M}$ Tris- $\mathrm{HCl}$ buffer $(\mathrm{pH} 8.9)$ containing $25 \mu \mathrm{l} 10 \mathrm{mM} \mathrm{5,5'-dithiobis-(2-)nitrobenzoic} \mathrm{acid} \mathrm{(DNTB)} \mathrm{and} \mathrm{the} \mathrm{absorbance}$ was read at $412 \mathrm{~nm}$ on a spectrophotometer within 30 minutes. Results were obtained from two independent experiments.

\subsubsection{Generation of ROS in MEF-LacZ cells}

ROS are generated by cells as by-products of normal cellular activity, but an increase in ROS in response to stress factors may lead to an overload of the anti-oxidant capacity, and may result in cell damage. Non-fluorescent 2',7'-dichlorodihydrofluorescein diacetate $\left(\mathrm{H}_{2} \mathrm{DCF}-\mathrm{DA}\right)$ can be used to measure the generation of ROS. Upon entering the cell, the acetate groups are cleaved off, and the remaining compound $\mathrm{H}_{2} \mathrm{DCF}$ remains inside the cell where it is oxidized by reactive species to the fluorescent compound DCF.

MEF-LacZ cells were seeded in 96-well tissue grade microtiter plates at a density of $5 \times 10^{3}$ cells per well and cultured in a humidified atmosphere at $37^{\circ} \mathrm{C}, 3 \% \mathrm{O}_{2}$ and $10 \%$ $\mathrm{CO}_{2}$. When the wells had reached approximately $80 \%$ confluence, cell culture medium was removed and cells were exposed to $100 \mu \mathrm{l}$ of nanoparticle suspension in cell culture medium containing $10 \%$ FCS $(0.3$ to $100 \mu \mathrm{g} / \mathrm{ml})$ for $4 \mathrm{~h}$, in triplicate wells. The $4 \mathrm{~h}$ time point was selected after pilot studies using exposure periods ranging from $15 \mathrm{~min}$ to $24 \mathrm{~h}$, and is in agreement with many other published studies using this assay (reviewed by Park et al. 2009b). In each experiment, cells exposed to $10 \%$ distilled water served as solvent control. Cells exposed to cell culture medium containing $10 \mu \mathrm{g} / \mathrm{ml}$ lipopolysaccharide (LPS) and $10 \mu \mathrm{g} / \mathrm{ml}$ phorbol myristate acetate (PMA) served as a positive control.

The stock solution of $\mathrm{H}_{2}$ DCF-DA ( $40 \mu \mathrm{M}$ in DMSO) was diluted 4000 times with PBS to yield a $10 \mu \mathrm{M}$ working solution. After $4 \mathrm{~h}$ exposure to $\mathrm{SiO}_{2} \mathrm{NPs}$, the cell culture medium was removed, cells were washed with warm PBS and incubated with freshly prepared $10 \mu \mathrm{M}$ $\mathrm{H}_{2}$ DCF-DA probe in PBS for 45 minutes at $37^{\circ} \mathrm{C}, 3 \% \mathrm{O}_{2}$ and $10 \% \mathrm{CO}_{2}$, while protected from light. Subsequently, probe that was not taken up by the cells was removed by washing the cells with warm PBS. A final aliquot of $100 \mu$ l of PBS was added to each well and fluorescence was measured at an excitation wavelength of $485 \mathrm{~nm}$ and an emission wavelength of 520 nm using a FLUOstar OPTIMA microplate reader (BMG LABTECH, Offenburg, Germany). 
At these wavelengths, $\mathrm{SiO}_{2} \mathrm{NPs}$ alone in PBS did not affect fluorescence. Results were obtained from at least two independent experiments.

\subsubsection{Data analysis}

Data from the $L a c Z$ gene mutation test in MEF-LacZ cells were analyzed by means of the non-parametric Kruskall-Wallis test and Mann-Whitney test where appropriate. Data from the micronucleus test were analyzed by means of the Pearson's chi square test. Data from the WST-1 test were analyzed using PROAST software version 23.2 (RIVM, Bilthoven, The Netherlands) (Slob 2002). The following exponential dose-response model was fitted to the data:

$$
y=a^{*} \exp (b x)
$$

where $y$ denotes the metabolic activity of the cells, and $x$ the concentration of the $\mathrm{SiO}_{2}$ NPs. Experiment $(n=3)$ was defined as a covariate for $a$ in the model. The $\mathrm{IC}_{20}$ was defined as the $\mathrm{SiO}_{2}$ NP concentration resulting in a $20 \%$ decrease of metabolic activity as compared to the solvent control group.
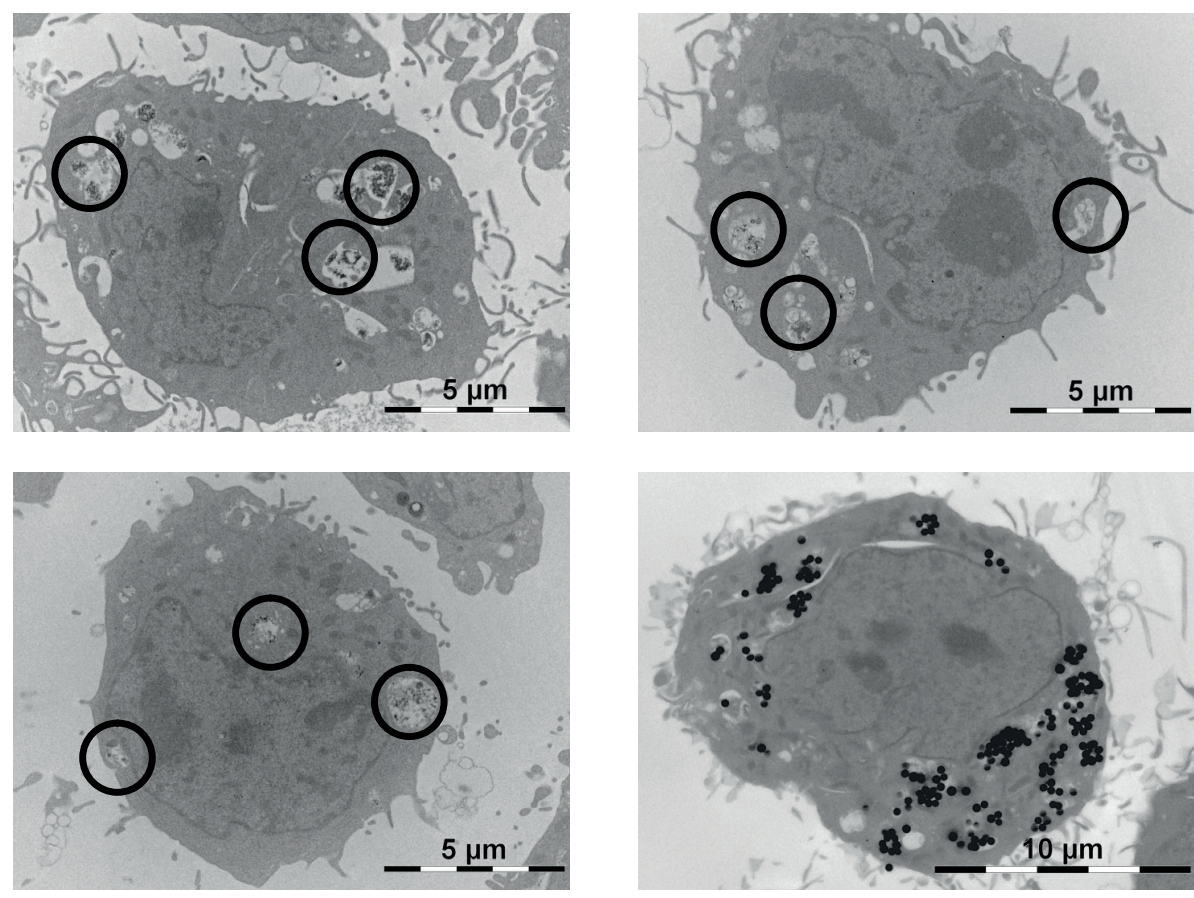

Figure 4.3 TEM images demonstrating uptake of $11 \mathrm{~nm}(\mathrm{a}), 34 \mathrm{~A}(\mathrm{~b}), 34 \mathrm{~B}(\mathrm{c})$ and $248 \mathrm{~nm}$ (d) silica nanoparticles by 3T3-L1 cells. 


\subsection{RESULTS}

\subsubsection{Silica nanoparticle uptake in 3T3-L1 cells}

TEM images of 3T3-L1 cells show that $\mathrm{SiO}_{2}$ NPs of all sizes tested were taken up into the cells after 16 hours of exposure to $50 \mu \mathrm{g} / \mathrm{ml}$. The NPs appeared to be mainly located in vesicles and although these vesicles were sometimes detected near the cell nucleus, no NPs were actually observed in the cell nucleus (Figure 4.3).
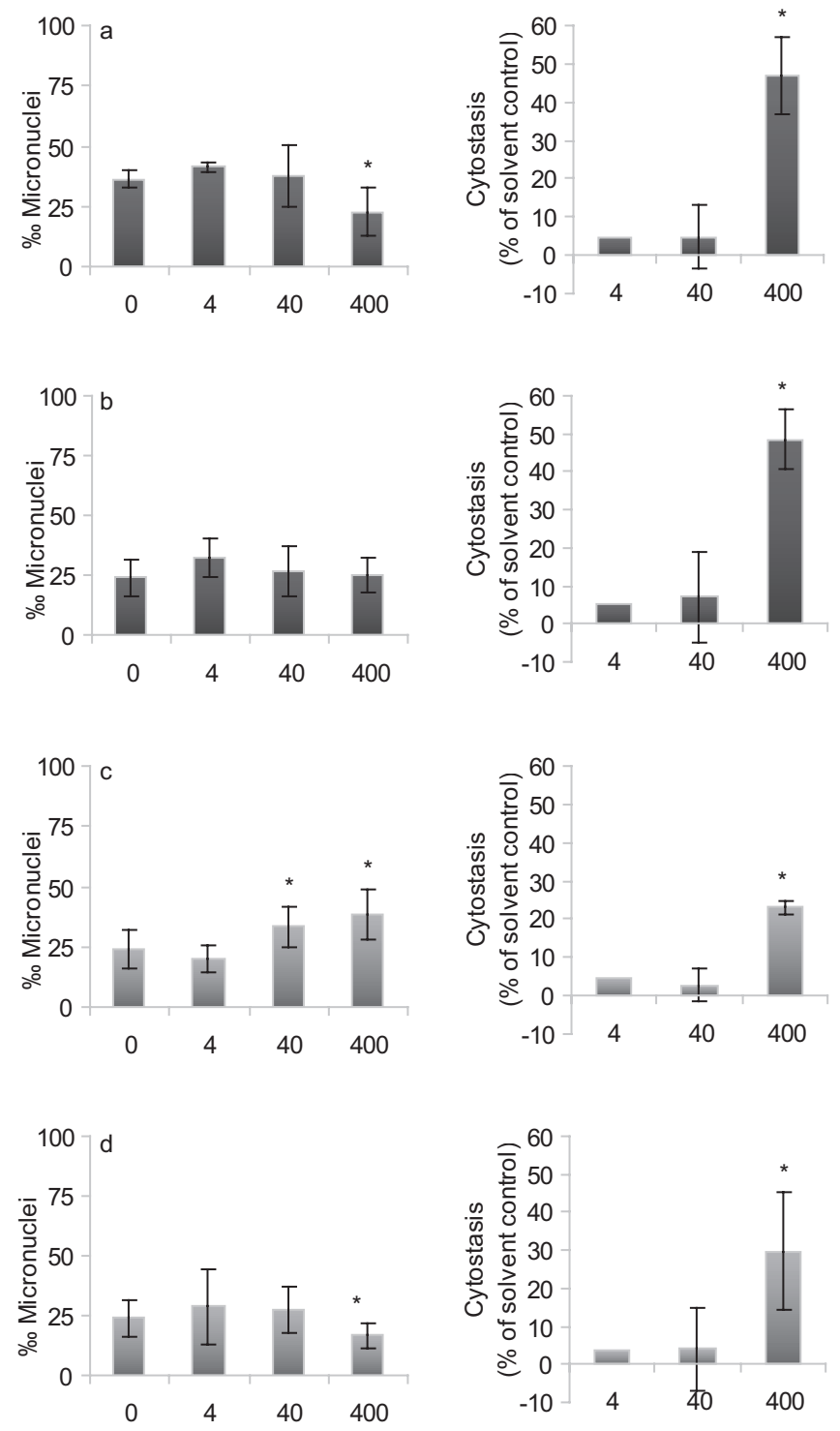

Concentration $(\mu \mathrm{g} / \mathrm{ml})$
Figure 4.4 Frequency of binucleated cells with micronuclei and ratio binucleated to mononucleated 3T3-L1 cells exposed to $11 \mathrm{~nm}$ (a), $34 \mathrm{~A}$ (b) 34B, (c) and 248 $\mathrm{nm}$ (d) silica nanoparticles. *Indicates a statistically significant difference compared to the solvent control $(p<0.05)$. 


\subsubsection{In vitro micronucleus results in 3T3-L1 cells}

The purpose of the micronucleus test is to identify chromosome aberrations by measuring the formation of micronuclei (MN) containing lagging chromosome fragments (clastogenic effects) or whole chromosomes (aneugenic effects). These chromosomal fragments are not able to migrate to the spindle poles during mitosis (nuclear division). A nuclear envelope forms around (each of) the chromosome fragment and is noticeable as a small micronucleus.

Figure 4.5 Mutant

\section{frequencies in MEF-LacZ} cells exposed to $11 \mathrm{~nm}(\mathrm{a})$, $34 \mathrm{~A}$ (b) 34B, (c) and 248 $\mathrm{nm}$ (d) silica nanoparticles. *Indicates a statistically significant difference compared to the solvent control $(p<0.05)$.
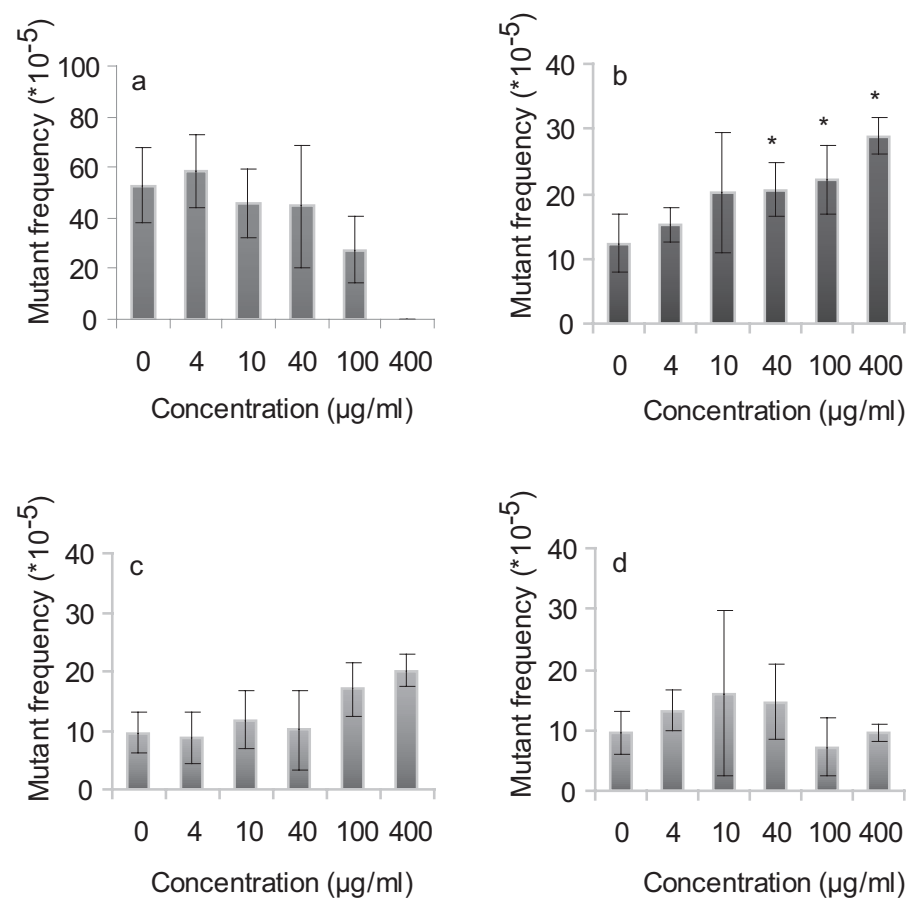

As indicated by the increased cytostasis, cell proliferation was significantly inhibited in 3T3-L1 cells at the highest test concentration of $400 \mu \mathrm{g} / \mathrm{ml}$ for all $\mathrm{SiO}_{2} \mathrm{NPs}$, but not at lower concentrations (Figure 4.4). At non-cytotoxic concentrations, a minor but statistically significant and dose-related increase in binucleated cells with $\mathrm{MN}$ was observed in cells exposed to the 34B $\mathrm{SiO}_{2}$ NPs only. Exposure to the positive control bleomycin resulted in an approximately 4-fold increase in binucleated cells with $\mathrm{MN}$ compared to the solvent control in every experiment (data not shown).

\subsubsection{LacZ gene mutation test in MEF-LacZ cells}

Gene mutations such as point mutations or base shifts are not detected by the micronucleus assay. Therefore, a gene mutation test was performed in mouse embryonic fibroblasts (MEF- 
lacZ) containing lacZ as a reporter gene. This test is capable of detecting various mutagenic events, including point mutations and chromosomal rearrangements (Mahabir et al. 2009).

$\mathrm{SiO}_{2} \mathrm{NPs}_{11}$ and $248 \mathrm{~nm}$ did not induce an increase in mutant frequencies (Figure 4.5). A dose related increase in mutant frequency was observed in MEF-LacZ cells exposed to both $34 \mathrm{~nm} \mathrm{SiO}_{2}$ NPs, which was statistically significant for the 34A only. Compared to the solvent control, the increase was at most 3-fold for the 34A particle and 2-fold for the 34B particle. The positive control MNU induced a 7-fold increase in mutant frequency compared to the solvent control (data not shown).
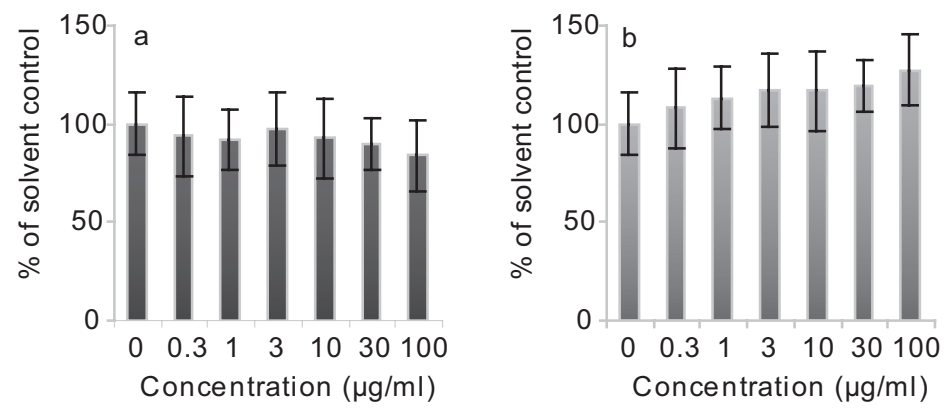

Figure 4.6 Metabolic activity of MEF-LacZ cells exposed to 34A (a) and 34B (b) silica nanoparticles, as measured by the WST-1 assay.

\subsubsection{Cytotoxicity in MEF-LacZ cells}

To determine whether the observed genotoxic effects of the two $34 \mathrm{~nm} \mathrm{SiO}{ }_{2} \mathrm{NPs}_{\text {occurred }}$ concentrations below cytotoxic concentrations, a WST-1 assay was performed. Metabolic activity of MEF-LacZ cells was slightly decreased after exposure to $34 \mathrm{~A} \mathrm{SiO}_{2} \mathrm{NPs}$ (Figure 4.6). Modelling of the WST-1 dose response data in MEF-LacZ cells showed that metabolic activity of exposed cells was decreased to $80 \%$ of that of control cells at a concentration of $85 \mu \mathrm{g} / \mathrm{ml}$ (Figure 4.7).



Figure 4.7 Dose-response curves of the metabolic activity of MEF-LacZ cells as a function of the 34A silica nanoparticle concentration. Data was fitted with the exponential doseresponse model: $y=a^{*} \exp (\mathrm{bx})$. Dashed lines represent $\mathrm{IC}_{20}$ value, i.e. the concentration at which the metabolic activity of exposed cells decreased $20 \%$ compared to control cells. Different lines and symbols represent different experiments. For each experiment MEF-LacZ cells were obtained from different embryos, which may contribute to the variable background in metabolic activity between the experiments. 


\subsubsection{Redox potential and generation of reactive oxygen species}

The potential contribution of reactive oxygen species to the observed increase in the occurrence of mutant frequencies in MEF-LacZ cells after exposure to the two $34 \mathrm{~nm} \mathrm{SiO}{ }_{2}$ NPs was investigated by determining the induction of ROS both in an acellular and in a cellular system. The metabolism of $\mathrm{H}_{2}$ DCF by ROS in MEF-LacZ cells exposed to the two 34 $\mathrm{nm} \mathrm{SiO}{ }_{2} \mathrm{NPs}$ was not increased at concentrations up to $100 \mu \mathrm{g} / \mathrm{ml}$ (Figure 4.8). However, the positive control $(10 \mu \mathrm{g} / \mathrm{ml}$ LPS and $10 \mu \mathrm{g} / \mathrm{ml} \mathrm{PMA})$ only induced a two-fold increase in ROS, indicating the assay was not very sensitive in this cell type. The metabolism of DTT in the acellular system was not increased by any of the $\mathrm{SiO}_{2} \mathrm{NPs}$ (data not shown).
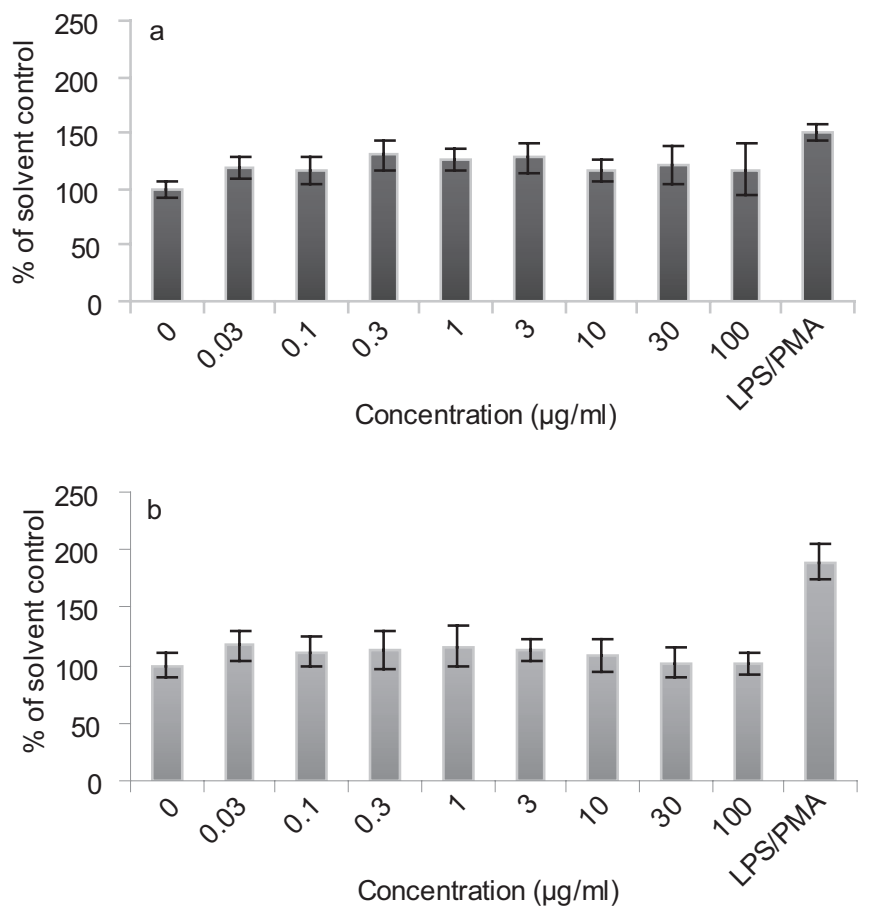

Figure 4.8 Generation of reactive oxygen species in MEF-LacZ cells exposed to 34A (a) and 34B (b) silica nanoparticles, as measured by the $\mathrm{H}_{2}$ DCF-DA assay.

\subsection{DISCUSSION}

In the current study, we investigated the potentially size-dependent effects of $\mathrm{SiO}_{2} \mathrm{NPs}$ in two genotoxicity assays. An important issue recently re-emphasized is that genotoxic effects are not relevant at high cytotoxic concentrations, as high levels of cytotoxicity may induce 
chromosomal damage as a secondary effect (Rossman 2009). For the micronucleus assay, cytotoxicity in 3T3-L1 cells was determined by assessing cytostasis for each treatment, which provides an accurate method of quantifying the effect on cell proliferation and the cytotoxic activity of a treatment. At the highest concentration tested $(400 \mu \mathrm{g} / \mathrm{ml})$ of each $\mathrm{SiO}_{2}$ nanoparticle, cytostasis was significantly increased compared to solvent control, indicating high cytotoxicity at this concentration. Cytostasis at the other test concentrations was not affected, confirming earlier results using a variety of cell viability tests of the same 30 (34), 80 (34) and 400 (248) nm SiO ${ }_{2}$ NPs in the same 3T3-L1 cells, as reported together with the comet assay (Barnes et al. 2008). In the absence of cytotoxicity, the 4 and $40 \mu \mathrm{g} /$ $\mathrm{ml}$ test concentrations were relevant for genotoxicity evaluation.

Cytotoxicity of $\mathrm{SiO}_{2} \mathrm{NPs}$ in MEF-lacZ cells was also low or absent at concentrations up to $100 \mu \mathrm{g} / \mathrm{ml}$ when determined with the WST-1 assay. However, the WST-1 and analogous assays used to assess cytotoxicity have been claimed to underestimate cytotoxicity because the metabolic activity of cells undergoing apoptosis does not necessarily decrease until the last stage of apoptosis (Rossman 2009). The use of the clonal survival assay may be a more appropriate assay for cytotoxicity, but is not compatible with the MEF-lacZ cells used in our studies, which are difficult to clone in the absence of intercellular contact. Nevertheless, our cytotoxicity results are in agreement with results of various other in vitro studies with $\mathrm{SiO}_{2}$ NPs (Adili et al. 2008; Brunner et al. 2006; Chang et al. 2007; Chung et al. 2007; Fahmy and Cormier 2009; Lu et al. 2009). Using a number of different cytotoxicity assays, these studies reported minimal cytotoxicity of amorphous $\mathrm{SiO}_{2} \mathrm{NPs}$ in epithelial cells and fibroblasts at concentrations of up to $100 \mu \mathrm{g} / \mathrm{ml}$. Evaluation of genotoxicity at concentrations up to $100 \mu \mathrm{g} / \mathrm{ml}$ of $\mathrm{SiO}_{2} \mathrm{NPs}$ in MEF-LacZ cells is therefore unlikely influenced by high cytotoxicity.

We previously reported that these $\mathrm{SiO}_{2}$ NPs elicited no response in the comet assay at concentrations up to $40 \mu \mathrm{g} / \mathrm{ml}$ (Barnes et al. 2008). The comet assay gives an indication of the potential of chemicals to induce single- or double-strand DNA breaks. Our results were consistent with the negative outcome in the comet assay after exposure of A549 human lung epithelial cells to luminescent $\mathrm{SiO}_{2} \mathrm{NPs}(50 \mathrm{~nm}$ ) for up to 72 hours (Jin et al. 2007). In contrast, $\mathrm{SiO}_{2} \mathrm{NPs}$ were found to be genotoxic in cultured breast cancer cells (MCF-7) (Pacheco et al. 2007). The comet assay is a highly sensitive test, and positive responses in the comet assay do not necessarily point toward genotoxicity since the DNA strand breaks detected may be reversible. On the other hand, a negative outcome of the comet assay does not necessarily prove the absence of genotoxicity, since DNA strand breaks are only one form of DNA damage that a chemical may induce. Therefore, evaluation of the genotoxic potential of chemicals or, in this case, NPs requires the use of assays detecting additional and irreversible genotoxicity endpoints.

The micronucleus assay is a commonly used test for evaluating the potential of chemicals to induce chromosomal aberrations, which may consist of chromosome breaks or whole chromosome loss. To the best of our knowledge, this is the first study to evaluate 
amorphous $\mathrm{SiO}_{2} \mathrm{NPs}$ in this assay. Using the same cell type, storage and exposure protocol as the previously reported comet assay, $34 \mathrm{~B} \mathrm{SiO}_{2} \mathrm{NPs}$ induced a minor, but dose related and statistically significant increase in chromosomal aberrations in 3T3-L1 mouse fibroblasts, while the other $\mathrm{SiO}_{2} \mathrm{NPs}$ elicited no effect. Similar to our studies with amorphous $\mathrm{SiO}_{2}$ NPs, Wang et al. (2007) reported genotoxicity of crystalline $\mathrm{SiO}_{2}$ particles in the in vitro micronucleus assay, while the comet assay was negative. It needs to be emphasized that, although both these assays detect DNA strand breaks, the endpoints do not completely overlap. In a different type of chromosomal aberration assay, $\mathrm{SiO}_{2}$-coated magnetic NPs of $50 \mathrm{~nm}$ did not induce chromosomal aberrations in Chinese hamster lung fibroblasts (Kim et al. 2006).

The different outcome for the 34B NPs in our study is surprising, since the TEM measured diameter of this nanoparticle was similar to that of the 34A NPs, which did not induce chromosomal aberrations. We have previously reported that these two NPs also elicited different responses in the embryonic stem cell test (Park et al. 2009a), suggesting that characteristics other than primary particle diameter contribute to the potential of these NPs to elicit effects in these assays.

Our micronucleus assay protocol involved the use of cytochalasine B as a cytokinesis blocker, which may inhibit the endocytosis of certain NPs (Papageorgiou et al. 2007). However, using a protocol similar to the one used in our study, increased frequencies of binucleated cells with $\mathrm{MN}$ were also found after exposure to aluminum oxide and anatase $\mathrm{TiO}_{2}$ NPs (Di Virgilio et al. 2009; Falck et al. 2009). This indicates that endocytosis of these NPs was not completely inhibited, although the effects of these NPs may have been underestimated.

The gene mutation assay is regularly used to evaluate a different genotoxicity endpoint than the micronucleus assay, specifically the potential of a chemical to induce gene mutations. This genotoxicity endpoint is commonly evaluated in vitro in a mammalian cell gene mutation tests with a reporter gene or in the bacterial reverse mutation assay (Ames test). We have evaluated for the first time the potential of $\mathrm{SiO}_{2} \mathrm{NPs}$ to induce gene mutations in mouse embryonic fibroblasts containing $L a c Z$ as a reporter gene, which is capable of detecting various mutagenic events such as point mutations and deletions induced by chemicals (Mahabir et al. 2009). Both $34 \mathrm{~nm} \mathrm{SiO}{ }_{2} \mathrm{NPs}$ ( $\mathrm{A}$ and $\mathrm{B}$ ) induced a dose related increase in gene mutations in MEF-LacZ cells, while those of $11 \mathrm{~nm}$ and 248 $\mathrm{nm}$ did not. Similar methodology was used in studies investigating the mutagenicity of single walled carbon nanotubes, $\mathrm{C}_{60}$ fullerenes, carbon black and diesel exhaust particles, but only the latter two induced an increase in mutant frequencies (Jacobsen et al. 2008; Jacobsen et al. 2007). In addition, $\mathrm{SiO}_{2}$-coated magnetic NPs of $50 \mathrm{~nm}$ were not genotoxic in the Ames test (Jin et al. 2007). However, the Ames test has been claimed to be less suitable for the evaluation of NPs, since not all particles may be able to cross the bacterial membrane (Landsiedel et al. 2009).

The lack of genotoxicity observed in NPs of $11 \mathrm{~nm}$ and $248 \mathrm{~nm}$ may be attributed to 
their larger hydrodynamic size in cell culture medium. We have previously assessed and reported the agglomeration status of these $\mathrm{SiO}_{2} \mathrm{NPs}$ by means of DLS in cell culture medium containing FCS at different time points (shortly after dispersion, 24 hours and 5 days after dispersion). The DLS data demonstrate that all particles are to some extent agglomerated/ aggregated in cell culture medium, and the state of agglomeration/aggregation varies with different time points after dispersion. Therefore, rather than a permanent agglomeration 'status', the agglomeration in cell culture medium actually appears to be a very dynamic process, and the relevant time point for determining the agglomeration 'status' is not

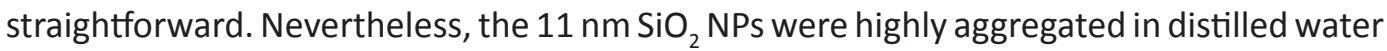
and this aggregation persisted in cell culture medium for embryonic stem cells (Park et al. 2009a). In the current study, the larger particle size of the $248 \mathrm{~nm}$ particles and the high level of aggregation of the $11 \mathrm{~nm}$ particles did not appear to prevent their uptake in 3T3L1 cells. However, at equal-mass concentrations for all particles, the number of particles (aggregates) available in the cell culture medium is lower for larger or highly aggregated particles. This in turn may lead to a lower number of cells in the cell population being affected by the $11 \mathrm{~nm}$ and the $248 \mathrm{~nm}$ particles compared to the two better dispersed 34 $\mathrm{nm}$ particles.

Our TEM studies further demonstrated that $\mathrm{SiO}_{2}$ NPs taken up by 3T3-L1 cells were mainly located in vacuoles, but the presence of $\mathrm{SiO}_{2} \mathrm{NPs}_{\text {in }}$ the cell nucleus could not be confirmed. In the micronucleus assay, the presence of micronuclei was scored in at least 1000 binucleated cells for every treatment in each of the three experiments. On average, micronuclei were observed in $3.3 \%$ of the $3 \mathrm{~T} 3-\mathrm{L} 1$ cells treated with $40 \mu \mathrm{g} / \mathrm{ml} 34 \mathrm{~B} \mathrm{SiO}_{2} \mathrm{NPs}$, i.e. in approximately 100 cells. Several thousands of cell transects have been examined

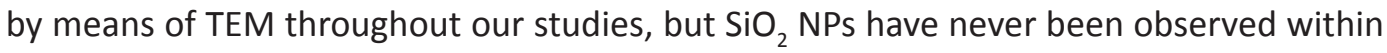
a nuclear profile. It should be noted that individual $11 \mathrm{~nm} \mathrm{SiO}{ }_{2}$ NPs are too small to be visualized in a nuclear profile by means of TEM. Nevertheless, our findings are consistent with others using fluorescently labeled or luminescent amorphous $\mathrm{SiO}_{2} \mathrm{NPs}$ and crystalline $\mathrm{SiO}_{2}$ particles, which were found to be almost exclusively located in lysosomes in regions near to but not in the cell nucleus (Gemeinhart et al. 2005; Jin et al. 2007; Kayle et al. 2010; Li et al. 2007). In contrast, one study reported the nuclear translocation of fluorescently labeled $\mathrm{SiO}_{2}$ NPs sized between 40 and $70 \mathrm{~nm}$ (Chen and von Mikecz 2005).

For the time being, we are uncertain of the mechanism(s) that would explain the genotoxic responses observed with the two $34 \mathrm{~nm} \mathrm{SiO}{ }_{2} \mathrm{NPs}_{\text {when }}$ their localization was primarily observed in vacuoles outside the cell nucleus. We can only postulate from the literature that NPs may alter two pathways that may result in indirect DNA damage (Gonzalez et al. 2008; Singh et al. 2009).

Firstly, the release of transition metal ions and/or the high surface area associated with NPs can promote the generation of ROS, resulting in oxidative DNA damage. This pathway can be attained without the presence of the NPs themselves in the cell nucleus, as has been demonstrated for $\mathrm{CoCr}$ particles (Papageorgiou et al. 2007). Exposure of human lung 
epithelial cells (A549) to amorphous $\mathrm{SiO}_{2}$ NPs did not induce an increase of 7,8-dihydroxodeoxyguanine, a marker of oxidative damage (Jin et al. 2007). In addition, results from both acellular and cellular assays indicated that the reactivity of $\mathrm{SiO}_{2} \mathrm{NPs}$ used in our study was low and did not result in generation of high levels of ROS either in solution or inside cells. However, given that the methodology used to measure ROS is rather insensitive, we cannot rule out the possibility that ROS may be involved in the induction of genotoxic effects.

Secondly, indirect DNA damage may result from mechanical hindrance of the mitotic process of the cells rather than the direct induction of DNA strand breaks, due to the presence of vacuoles containing NPs in the cytoplasm of the cells during mitosis. Interferences with mitotic processes have been reported for various NPs, including $\mathrm{SiO}_{2} \mathrm{NPs}$ (AshaRani et al. 2009a; AshaRani et al. 2009b; Pernodet et al. 2006; Villanueva et al. 2009; Wang et al. 2009). For instance, exposure of human lung fibroblasts and glioblastoma cells to starch-coated silver NPs induced the formation of chromosomal aberrations and micronuclei, which was associated with significant cytoskeleton deformations, down-regulation of actin binding proteins and cell cycle arrest in the gap2/mitosis phase (AshaRani et al. 2009a; 2009b). Modification of the actin structure of human dermal fibroblasts exposed to citrate/gold NPs was suggested to be the result of mechanical hindrance by the unusually large number of vacuoles (Pernodet et al. 2006). Mechanical hindrance may also induce indirect DNA damage by affecting microtubules, which are important in cellular transport of proteins required for DNA repair processes (Gonzalez et al. 2008). In our study, differences in number of vacuoles between control cells and those exposed to $50 \mu \mathrm{g} / \mathrm{ml}$ NPs of different sizes were not qualitatively obvious. However, detailed quantitative studies of vacuole numbers are needed to exclude the contribution of mechanical hindrance by NPs to the observed effects in the genotoxicity assays.

So far, our studies indicate that two $34 \mathrm{~nm}$ amorphous $\mathrm{SiO}_{2} \mathrm{NPs}$ may not be as inert as previously thought. In light of the current and anticipated applications of $\mathrm{SiO}_{2} \mathrm{NPs}$ in the pharmaceutical industry and in the food sector, in vivo studies are needed to further evaluate the relevance of the effects found in vitro. The 11 and $248 \mathrm{~nm} \mathrm{SiO}{ }_{2} \mathrm{NPs}$ did not show any genotoxic effect in either assay. Therefore, it needs to be emphasized that not all $\mathrm{SiO}_{2} \mathrm{NPs}$ have the potential to be genotoxic, and this may rather depend on as yet unidentified specific nanoparticle characteristics. NPs which are similar in both chemical composition and primary size exerted different effects in embryonic stem cell differentiation and micronucleus assays, suggesting that safety evaluation of NPs needs to consider additional NP characteristics. The identification of additional characteristic(s) of NPs that may determine their response in toxicity assays would help to assess the relevance of our findings to human exposure to these and other types of $\mathrm{SiO}_{2} \mathrm{NPs}$. A better understanding of the mechanism by which these effects occurred may help to identify these NP characteristics. Identification of toxicity-determining NP characteristics can also aid producers in the development of safe $\mathrm{SiO}_{2} \mathrm{NPs}$. In the meantime, caution is needed when comparing results across studies using different types of $\mathrm{SiO}_{2} \mathrm{NPs}$. 
In summary, genotoxic effects of 34B $\mathrm{SiO}_{2} \mathrm{NPs}$ were observed in 3T3-L1 cells and of the $34 \mathrm{~A}$ and $34 \mathrm{~B} \mathrm{SiO}_{2}$ NPs in MEF-lacZ cells as determined by the micronucleus assay and the LacZ gene mutation assay, respectively, at non-cytotoxic concentrations. The effects were not observed for all four $\mathrm{SiO}_{2} \mathrm{NPs}$, despite their similar chemical composition. In addition, even $\mathrm{SiO}_{2} \mathrm{NPs}$ of similar TEM measured primary size $(34 \mathrm{~nm})$ elicited different effects in the micronucleus assay, suggesting that nanoparticle characteristics other than chemical composition and primary size play an important role. All NPs were taken up by 3T3-L1 cells, but the presence of $\mathrm{SiO}_{2}$ NPs in the cell nucleus could not be demonstrated by TEM imaging, indicating that the effects were not caused by a direct interaction of the $\mathrm{SiO}_{2} \mathrm{NPs}$ with the DNA, but rather by an indirect mechanism. The involvement of ROS cannot be excluded, although the $\mathrm{SiO}_{2}$ NPs had low redox potential and exposure of the MEF-LacZ cells did not result in the generation of high levels of ROS. The possibility of mechanical hindrance of mitotic processes as an indirect mechanism underlying these effects needs to be investigated. The question remains whether the observed effects are biologically relevant for human exposure to these $34 \mathrm{~nm} \mathrm{SiO}{ }_{2}$ NPs. In vivo studies may reveal whether the effects found in vitro can be reproduced in vivo at relevant exposure concentrations. In addition, the nanoparticle characteristics determining these effects need to be elucidated in order to assess the relevance of these findings for human exposure to a wide variety of $\mathrm{SiO}_{2}$ NPs.

\section{ACKNOWLEDGMENTS}

This work was funded by the EU FP6 project Nanolnteract (NMP4-CT-2006-033231). The authors thank Liset de la Fonteijne, Daan Leseman, Nick van Oijen and Bert Verlaan for their technical assistance, Dr. Martijn Dollé for providing the LacZ assay method graphic, and Prof. Henk van Loveren for critically reviewing the manuscript. 


\section{REFERENCES}

Adili A, Crowe S, Beaux MF, Cantrell T, Shapiro PJ, Mcllroy DN, Gustin KE. 2008. Differential cytotoxicity exhibited by silica nanowires and nanoparticles. Nanotoxicology 2(1):1 - 8 .

Areva S, Aaritalo V, Tuusa S, Jokinen M, Linden M, Peltola T. 2007. Sol-Gel-derived $\mathrm{TiO}_{2}-\mathrm{SiO}_{2}$ implant coatings for direct tissue attachment. Part II: Evaluation of cell response. J Mater Sci Mater Med 18(8):1633-42.

AshaRani PV, Hande MP, Valiyaveettil S. 2009a. Anti-proliferative activity of silver nanoparticles. BMC Cell Biol 10:65.

AshaRani PV, Low Kah Mun G, Hande MP, Valiyaveettil S. 2009b. Cytotoxicity and genotoxicity of silver nanoparticles in human cells. ACS Nano 3(2):279-90.

Barik TK, Sahu B, Swain V. 2008. Nanosilica-from medicine to pest control. Parasitol Res 103(2):2538.

Barnes CA, Elsaesser A, Arkusz J, Smok A, Palus J, Lesniak A, Salvati A, Hanrahan JP, Jong WH, Dziubaltowska $E$ and others. 2008. Reproducible comet assay of amorphous silica nanoparticles detects no genotoxicity. Nano Lett 8(9):3069-74.

Bharali DJ, Klejbor I, Stachowiak EK, Dutta P, Roy I, Kaur N, Bergey EJ, Prasad PN, Stachowiak MK. 2005. Organically modified silica nanoparticles: a nonviral vector for in vivo gene delivery and expression in the brain. Proc Natl Acad Sci U S A 102(32):11539-44.

Brunner TJ, Wick P, Manser P, Spohn P, Grass RN, Limbach LK, Bruinink A, Stark WJ. 2006. In vitro cytotoxicity of oxide nanoparticles: comparison to asbestos, silica, and the effect of particle solubility. Environ Sci Technol 40(14):4374-81.

Chang JS, Chang KL, Hwang DF, Kong ZL. 2007. In vitro cytotoxicitiy of silica nanoparticles at high concentrations strongly depends on the metabolic activity type of the cell line. Environ Sci Technol 41(6):2064-8.

Chen M, von Mikecz A. 2005. Formation of nucleoplasmic protein aggregates impairs nuclear function in response to $\mathrm{SiO}_{2}$ nanoparticles. Exp Cell Res 305(1):51-62.

Chung TH, Wu SH, Yao M, Lu CW, Lin YS, Hung Y, Mou CY, Chen YC, Huang DM. 2007. The effect of surface charge on the uptake and biological function of mesoporous silica nanoparticles in 3T3L1 cells and human mesenchymal stem cells. Biomaterials 28(19):2959-66.

Di Virgilio AL, Reigosa M, Arnal PM, Fernandez Lorenzo de Mele M. 2009. Comparative study of the cytotoxic and genotoxic effects of titanium oxide and aluminium oxide nanoparticles in Chinese hamster ovary (CHO-K1) cells. J Hazard Mater.

Dollé ME, Martus HJ, Gossen JA, Boerrigter ME, Vijg J. 1996. Evaluation of a plasmid-based transgenic mouse model for detecting in vivo mutations. Mutagenesis 11(1):111-8.

Duffin R, Tran L, Brown D, Stone V, Donaldson K. 2007. Proinflammogenic effects of low-toxicity and metal nanoparticles in vivo and in vitro: highlighting the role of particle surface area and surface reactivity. Inhal Toxicol 19(10):849-56.

Fahmy B, Cormier SA. 2009. Copper oxide nanoparticles induce oxidative stress and cytotoxicity in airway epithelial cells. Toxicol In Vitro 23(7):1365-71.

Falck GC, Lindberg HK, Suhonen S, Vippola M, Vanhala E, Catalan J, Savolainen K, Norppa H. 2009. Genotoxic effects of nanosized and fine $\mathrm{TiO}_{2}$. Hum Exp Toxicol 28(6-7):339-52.

Gemeinhart RA, Luo D, Saltzman WM. 2005. Cellular fate of a modular DNA delivery system mediated by silica nanoparticles. Biotechnol Prog 21(2):532-7. 
Genschow E, Seiler A, Spielman H. 2004. Considering the test performance of three class data using linear discriminant analysis. Altern Lab Anim 32:713-23.

Gonzalez L, Lison D, Kirsch-Volders M. 2008. Genotoxicity of engineered nanomaterials: A critical review. Nanotoxicology 2(4):252-273.

Hamoir J, Nemmar A, Halloy D, Wirth D, Vincke G, Vanderplasschen A, Nemery B, Gustin P. 2003. Effect of polystyrene particles on lung microvascular permeability in isolated perfused rabbit lungs: role of size and surface properties. Toxicol Appl Pharmacol 190(3):278-85.

Hansen SF, Michelson ES, Kamper A, Borling P, Stuer-Lauridsen F, Baun A. 2008. Categorization framework to aid exposure assessment of nanomaterials in consumer products. Ecotoxicology 17(5):438-47.

Jacobsen NR, Pojana G, White P, Moller P, Cohn CA, Korsholm KS, Vogel U, Marcomini A, Loft S, Wallin H. 2008. Genotoxicity, cytotoxicity, and reactive oxygen species induced by single-walled carbon nanotubes and $\mathrm{C}(60)$ fullerenes in the FE1-Mutatrade markMouse lung epithelial cells. Environ Mol Mutagen 49(6):476-87.

Jacobsen NR, Saber AT, White P, Moller P, Pojana G, Vogel U, Loft S, Gingerich J, Soper L, Douglas GR and others. 2007. Increased mutant frequency by carbon black, but not quartz, in the lacZ and cll transgenes of muta mouse lung epithelial cells. Environ Mol Mutagen 48(6):451-61.

Jin Y, Kannan S, Wu M, Zhao JX. 2007. Toxicity of luminescent silica nanoparticles to living cells. Chem Res Toxicol 20(8):1126-33.

Kayle S, Fenaroli F, Lynch I, Cottell DC, Salvati A, Dawson KA. 2010. Time and space resolved uptake study of silical dioxide nanoparticles by human cells. Submitted for publication.

Kim JS, Yoon TJ, Yu KN, Kim BG, Park SJ, Kim HW, Lee KH, Park SB, Lee JK, Cho MH. 2006. Toxicity and tissue distribution of magnetic nanoparticles in mice. Toxicol Sci 89(1):338-47.

Landsiedel R, Kapp MD, Schulz M, Wiench K, Oesch F. 2009. Genotoxicity investigations on nanomaterials: methods, preparation and characterization of test material, potential artifacts and limitations--many questions, some answers. Mutat Res 681(2-3):241-58.

Li H, Haberzettl P, Albrecht C, Hohr D, Knaapen AM, Borm PJ, Schins RP. 2007. Inhibition of the mitochondrial respiratory chain function abrogates quartz induced DNA damage in lung epithelial cells. Mutat Res 617(1-2):46-57.

Limbach LK, Li Y, Grass RN, Brunner TJ, Hintermann MA, Muller M, Gunther D, Stark WJ. 2005. Oxide nanoparticle uptake in human lung fibroblasts: effects of particle size, agglomeration, and diffusion at low concentrations. Environ Sci Technol 39(23):9370-6.

Lu S, Duffin R, Poland C, Daly P, Murphy F, Drost E, Macnee W, Stone V, Donaldson K. 2009. Efficacy of simple short-term in vitro assays for predicting the potential of metal oxide nanoparticles to cause pulmonary inflammation. Environ Health Perspect 117(2):241-7.

Mahabir AG, Zwart E, Schaap M, van Benthem J, de Vries A, Hernandez LG, Hendriksen CF, van Steeg H. 2009. lacZ mouse embryonic fibroblasts detect both clastogens and mutagens. Mutat Res 666(1-2):50-56.

Merget R, Bauer T, Kupper HU, Philippou S, Bauer HD, Breitstadt R, Bruening T. 2002. Health hazards due to the inhalation of amorphous silica. Arch Toxicol 75(11-12):625-34.

Monteiller C, Tran L, MacNee W, Faux S, Jones A, Miller B, Donaldson K. 2007. The pro-inflammatory effects of low-toxicity low-solubility particles, nanoparticles and fine particles, on epithelial cells in vitro: the role of surface area. Occup Environ Med 64(9):609-15.

Pacheco SE, Mashayekhi H, Jiang W, Xing B, Arcaro KF. DNA damaging effects of nanoparticles in 
breast cancer cells; 2007 April 14-18, 2007; Los Angles, CA. p Abstract number 3477.

Papageorgiou I, Brown C, Schins R, Singh S, Newson R, Davis S, Fisher J, Ingham E, Case CP. 2007. The effect of nano- and micron-sized particles of cobalt-chromium alloy on human fibroblasts in vitro. Biomaterials 28(19):2946-58.

Park MVDZ, Annema W, Salvati A, Lesniak A, Elsaesser A, Barnes C, McKerr G, Howard CV, Lynch I, Dawson KA and others. 2009a. In vitro developmental toxicity test detects inhibition of stem cell differentiation by silica nanoparticles. Toxicol Appl Pharmacol 240:108-116.

Park MVDZ, Lankveld DPK, van Loveren H, de Jong W. 2009b. The status of in vitro toxicity studies in risk assessment of nanomaterials Nanomedicine 4(6):669-685.

Pernodet N, Fang X, Sun Y, Bakhtina A, Ramakrishnan A, Sokolov J, Ulman A, Rafailovich M. 2006. Adverse effects of citrate/gold nanoparticles on human dermal fibroblasts. Small 2(6):766-73.

Rossman TG. 2009. Inappropriate cytotoxicity measurements. Environ Mol Mutagen 50(2):81.

Santra S, Yang H, Dutta D, Stanley JT, Holloway PH, Tan W, Moudgil BM, Mericle RA. 2004. TAT conjugated, FITC doped silica nanoparticles for bioimaging applications. Chem Commun (Camb) (24):2810-1.

SCENIHR. 2009. Risk Assessment of Products of Nanotechnologies, adopted at the 28th plenary meeting on 19 January 2009. European Commission, Brussels, Belgium.: European Commission.

Singh N, Manshian B, Jenkins GJ, Griffiths SM, Williams PM, Maffeis TG, Wright CJ, Doak SH. 2009. NanoGenotoxicology: the DNA damaging potential of engineered nanomaterials. Biomaterials 30(23-24):3891-914.

Slob W. 2002. Dose-response modeling of continuous endpoints. Toxicol Sci 66(2):298-312.

Slowing, II, Vivero-Escoto JL, Wu CW, Lin VS. 2008. Mesoporous silica nanoparticles as controlled release drug delivery and gene transfection carriers. Adv Drug Deliv Rev 60(11):1278-88.

Stöber W, Fink A, Bohn E. 1968. Controlled growth of monodisperse silica spheres in the micron size range. J. Colloid Interface Sci. 26(1):62-9.

Trewyn BG, Giri S, Slowing, II, Lin VS. 2007. Mesoporous silica nanoparticle based controlled release, drug delivery, and biosensor systems. Chem Commun (Camb)(31):3236-45.

Villanueva A, Canete M, Roca AG, Calero M, Veintemillas-Verdaguer S, Serna CJ, Morales Mdel P, Miranda R. 2009. The influence of surface functionalization on the enhanced internalization of magnetic nanoparticles in cancer cells. Nanotechnology 20(11):115103.

Wang F, Gao F, Lan M, Yuan H, Huang Y, Liu J. 2009. Oxidative stress contributes to silica nanoparticleinduced cytotoxicity in human embryonic kidney cells. Toxicol In Vitro 23(5):808-15.

Wang JJ, Sanderson BJ, Wang H. 2007. Cytotoxicity and genotoxicity of ultrafine crystalline $\mathrm{SiO}_{2}$ particulate in cultured human lymphoblastoid cells. Environ Mol Mutagen 48(2):151-7.

Woodrow Wilson International Center for Scholars. 2009. An inventory of nanotechnologybased consumer products currently on the market. Woodrow Wilson International Center for Scholars.

Yang H, Liu C, Yang D, Zhang H, Xi Z. 2009. Comparative study of cytotoxicity, oxidative stress and genotoxicity induced by four typical nanomaterials: the role of particle size, shape and composition. J Appl Toxicol 29(1):69-78. 



\section{CHAPTER 5}

\section{IN VITRO EVALUATION OF CYTOTOXIC AND INFLAMMATORY PROPERTIES OF SILICA NANOPARTICLES OF DIFFERENT SIZES IN MURINE RAW 264.7 MACROPHAGES}

${ }^{1}$ Laboratory for Health Protection Research, National Institute for Public Health and the Environment, $3720 \mathrm{BA}$, Bilthoven, the Netherlands

${ }^{2}$ Department of Toxicogenomics, Maastricht University, 6200 MD Maastricht, the Netherlands

${ }^{3}$ Centre for BioNano Interactions, School of Chemistry and Chemical Biology, University College Dublin, Belfield, Dublin 4, Ireland

${ }^{4}$ Centre for Molecular Bioscience, University of Ulster, Coleraine, BT52 1SA, United Kingdom ${ }^{5}$ Institute for Risk Assessment Sciences, University of Utrecht, 3508 TD, Utrecht, The Netherlands 



\section{ABSTRACT}

The biological response to four well-characterized amorphous silica nanoparticles was investigated in RAW 264.7 macrophages in view of their potential application as drug carriers to sites of inflammation. All silica nanoparticles induced cell membrane damage (LDH), reduced metabolic activity (WST-1), generated ROS and released various cytokines, but to different extents. Two silica nanoparticles of $34 \mathrm{~nm}$ ( $A$ and B) with different zetapotentials were more cytotoxic than (aggregated) $11 \mathrm{~nm}$ and $248 \mathrm{~nm}$ nanoparticles, while cytokines were mostly induced by the (aggregated) $11 \mathrm{~nm}$ and only one of the 34 $\mathrm{nm}$ nanoparticles (34A). The results indicate that specific silica nanoparticles may have counterproductive effects, for example when used as carriers of anti-inflammatory drugs. The physicochemical properties determining the response of nanoparticles vary for different responses, implying that a screening approach for the safe development of nanoparticles needs to consider the role of combinations of (dynamic) physicochemical properties and needs to include multiple toxicity endpoints.

\subsection{INTRODUCTION}

In the biomedical field, much research effort is directed towards the development of amorphous silica $\left(\mathrm{SiO}_{2}\right)$ ENMs as carriers for diagnostic labels, non-viral DNA transfection agents, enhanced intracellular delivery or more specific targeting of drugs (see for example reviews by Agasti et al. 2010; Jarzyna et al. 2010; and Roy et al. 2008). An interesting aspect of NPs biodistribution is that they tend to accumulate at sites of inflammation due to increased vascular permeability (Moulari et al. 2008). In addition, inflamed areas are marked by the presence of high numbers of immune related cells such as macrophages, and various in vivo studies have shown that macrophages play an important role in scavenging particles from the systemic circulation, resulting in an accumulation of NPs in macrophage rich organs such as the liver, lung, spleen and bone marrow (Chen et al. 2003; De Jong et al. 2008; Fischer and Chan 2007; Hamoir et al. 2003; Lankveld et al. 2010; Sadauskas et al. 2007). Taking advantage of this accumulation, drug research is exploring possibilities for use of amorphous $\mathrm{SiO}_{2}$ NPs as drug carriers specifically targeting sites of inflammation (Ulbrich and Lamprecht 2010). For example, the selective delivery of the inflammatory bowel disease drug 5ASA to inflamed intestinal tissue in mice was significantly enhanced by covalently binding the drug to the surface of $\mathrm{SiO}_{2} \mathrm{NPs}$ (Moulari et al. 2008). Noteworthy

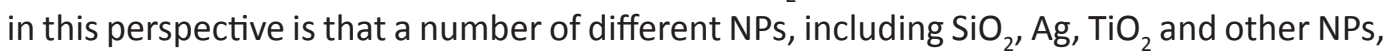
have been shown to induce biomarkers of oxidative stress and inflammation, such as ROS and cytokines (Carlson et al. 2008; Dutta et al. 2007; Kang et al. 2008; Sayes et al. 2007; Veranth et al. 2007), which may counteract the benefits of using NPs as drug carriers in the treatment of inflammatory diseases.

To ensure development of ENMs that are safe to use, it would be beneficial to identify the physico-chemical characteristic(s) that determine their hazardous properties, such 
as chemical composition, primary or hydrodynamic size, shape and surface composition and charge. Several in vitro cytotoxicity studies assessing the potential hazards of $\mathrm{SiO}_{2}$ ENMs have been published, but outcomes are not always in agreement with each other (Akhtar et al. 2010; Nabeshi et al. 2010; Napierska et al. 2009; Shi et al. 2010; Tao et al. 2009; Thomassen et al. 2010; Waters et al. 2009). Direct comparisons between studies are often difficult as they use ENMs from different suppliers and produced via different synthesis methods, which may lead to differences in impurities and detailed surface chemistry of the NPs, and this may have an impact on their toxicity. Indeed, even batchto-batch differences in ENMs from the same supplier may exist, as many ENM production processes are not yet sufficiently standardized and controlled. $\mathrm{SiO}_{2} \mathrm{NPs}$ are not necessarily produced, stored or handled under sterile conditions, yet few studies report testing their $\mathrm{SiO}_{2}$ (or indeed other) NPs for the presence of potent inflammatory agents such as lipopolysaccharides (LPS), which has been shown to increase the cytotoxic effects of $\mathrm{SiO}_{2}$ NPs (Shi et al. 2010). This variability in $\mathrm{SiO}_{2}$ ENMs underlines the necessity of thoroughly characterizing ENMs used in toxicity studies. Lack of ENM characterization leaves room for suggestive or erroneous interpretation of the results, complicates comparison across studies and hinders addressing the issue of whether one type of $\mathrm{SiO}_{2}$ ENM may be more hazardous than others.

The aim of this study was to investigate the differences in the hazardous potentials of a variety of well-characterized, solid amorphous spherical $\mathrm{SiO}_{2} \mathrm{NPs}$. In view of the envisioned application of amorphous $\mathrm{SiO}_{2} \mathrm{NPs}$ as drug carriers to sites of inflammation containing high numbers of immune related cells, a mouse peritoneal macrophage cell line, RAW 264.7 was selected to study potentially counterproductive cellular responses and inflammation properties of the $\mathrm{SiO}_{2}$ NPs.

\subsection{MATERIALS AND METHODS}

\subsubsection{Silica nanoparticles}

The four different solid, spherical amorphous $\mathrm{SiO}_{2} \mathrm{NPs}$ used in this study were obtained from Glantreo, Ltd., Cork, Ireland. The particles were synthesized via the Stöber method without any stabilizer (Stöber et al. 1968). To avoid potential interference from synthesis residues and solvents, NPs were dialyzed extensively against a very large excess of pure MilliQ water. The post-dialysis concentration of NPs was determined gravimetrically after freeze-drying a known volume of the dialyzed suspension. The endotoxin levels in the obtained particle stock solutions were below the detection limit of $<0.0625 \mathrm{IU} / \mathrm{ml}$ in the Limulus Amoebocyte Lysate (Gel-clot) assay and tested negative for the presence of bacterial or fungal infection, as determined by inoculation on Columbia sheep blood agar plates (Oxoid Ltd), respectively (data not shown).

Details on the characterization of these NPs have been reported previously (Barnes et 
al. 2008; Park et al. 2009a; Park et al. 2011) and are summarized in Table 5.1. Transmission Electron Microscopy (TEM) measurements revealed that the primary diameters of the four different NPs were 11, 34, 34 and $248 \mathrm{~nm}$, respectively. The two $34 \mathrm{~nm}$ particles had significantly different zeta potentials in deionized water, and will be designated as 34A $(\zeta-33.7)$ and 34B $(\zeta-10.6)$. The polydispersity index and dynamic light scattering measurements revealed that especially the $11 \mathrm{~nm} \mathrm{SiO} \mathrm{NPs}_{2}$ were highly aggregated in deionized water, and both $34 \mathrm{~nm}$ particles were aggregated to a smaller extent. The 248 $\mathrm{nm}$ particles were relatively well dispersed.

Shortly before the start of each experiment, $\mathrm{SiO}_{2} \mathrm{NPs}$ were thoroughly vortexed (20s at $1500 \mathrm{rpm}$ ), diluted in distilled water and dispersed in the same cell culture medium used to routinely culture the cells.

\begin{tabular}{|c|c|c|c|}
\hline $\begin{array}{l}\text { NP size }{ }^{a} \\
{[\mathrm{~nm}]}\end{array}$ & $\begin{array}{l}\text { zeta potential } \zeta \\
{[\mathrm{mV}]}\end{array}$ & $\begin{array}{l}\text { Hydrodynamic size } \\
\text { [nm] }\end{array}$ & $\mathrm{PDI}^{c}$ \\
\hline $11.0(2.2)$ & $-43.3(11.8)$ & $103.1(1.9)$ & $0.792(0.011)$ \\
\hline 33.7 (4.0) & $-33.7(3.0)$ & 77.9 (1.1) & $0.259(0.094)$ \\
\hline 33.7 (6.1) & $-10.6(0.9)$ & 65.9 (1.7) & $0.374(0.068)$ \\
\hline $247.9(24.1)$ & $-49.1(0.5)$ & $269.0(7.1)$ & $0.049(0.020)$ \\
\hline
\end{tabular}

Table 4.1 Characterization of silica nanoparticles shortly after dispersion in deionized water.

\subsubsection{Cell culture}

The murine peritoneal macrophage RAW 264.7 was obtained from ATTC and routinely cultured at $37^{\circ} \mathrm{C}$ and $5 \% \mathrm{CO}_{2}$ in DMEM/F12 + GlutaMAX -1 (Gibco 31331) supplemented with 10 vol\% FCS (Gibco 16010-159), 1 vol\% Penicillin-Streptomycin solution (10000 U/mL / 10000 mg/mL, Gibco 15040), and 1 vol\% 100 mM sodium pyruvate (Gibco 11360).

\subsubsection{Cellular metabolic activity (WST-1)}

The metabolic conversion of WST-1 by the macrophages after $24 \mathrm{~h}$ exposure to $0.03-100$ $\mu \mathrm{g} / \mathrm{ml} \mathrm{SiO}_{2}$ NPs was evaluated using the WST-1 Cell Proliferation Reagent (Roche, Almere, the Netherlands), as described earlier (Park et al. 2009a; Park et al. 2011). A decrease in cellular metabolic conversion of WST into a colored formazan dye may be caused by cell death, a decrease in enzyme activity, a decrease in cellular proliferation, or a combination of thereof, and is commonly referred to as reflecting cytotoxicity. Briefly, cells were seeded in 96-well tissue grade microtiter plates at $2 \times 10^{4}$, leading to near confluent monolayers after $24 \mathrm{~h}$. Upon reaching near confluency, cell culture medium was removed and fresh cell culture medium containing $0.3-100 \mu \mathrm{g} / \mathrm{ml} \mathrm{SiO}_{2} \mathrm{NPs}(100 \mu \mathrm{l}$ per well) was added. Each 
96-well plate also included cells exposed to 5 vol\% DMSO as a positive control. After 24 $\mathrm{h}$, cells were incubated with WST-1 reagent for $3 \mathrm{~h}$ and absorbance was measured using a SpectraMax ${ }^{\circledR} 190$ scanning multiwell spectrophotometer (Molecular Devices, Sunnyvale, USA) at a wavelength of $440 \mathrm{~nm}$ and a reference wavelength of $620 \mathrm{~nm}$. Interference of the $\mathrm{SiO}_{2}$ NPs with the WST-1 assay was experimentally excluded, as reported previously (Park et al. 2009a). At least three independent experiments were performed.

\subsubsection{Cellular membrane integrity (LDH)}

The LDH assay measures metabolic conversion of lactate to pyruvate by lactate dehydrogenase (LDH). LDH activity after $24 \mathrm{~h}$ exposure to $0.3-100 \mu \mathrm{g} / \mathrm{ml} \mathrm{SiO} \mathrm{NPs}_{2}$ was determined using the CytoTox-ONE ${ }^{\mathrm{TM}}$ Homogeneous Membrane Integrity Assay (Promega, Leiden, The Netherlands) according to the manufacturer's specifications. A decrease in total LDH activity measured in lysed cells and their cell culture supernatant together represents cell death, a decrease in enzyme activity, a decrease in cellular proliferation, or a combination of thereof. LDH is a stable cytoplasmic enzyme present in all cells, which is rapidly released into the cell culture supernatant upon damage to the cell membrane. Therefore, an increase in LDH activity measured in the cell culture supernatant alone is representative for cell membrane damage which, similar to the WST-1, is commonly referred to as reflecting cytotoxicity. Extracellular LDH is corrected for the total LDH activity in the cells undergoing the same treatment, to avoid false negative results in cases where the NP treatment caused an inhibition of cell proliferation and as such caused a lower amount of LDH to be available to leak out of damaged cells (Park et al. 2009b; Stone et al. 2009).

Cells were exposed to $\mathrm{SiO}_{2}$ NPS in the same way as for the WST-1 assay. Each 96-well plate also included cells exposed to 5 vol\% DMSO as a positive control. At the end of the 24 h exposure period, 96-well plates were equilibrated to room temperature and LDH activity was measured. One set of triplicate wells was used to determine total LDH activity after lysing cells with $10 \mu \mathrm{l}$ of $9 \% \mathrm{w} / \mathrm{v}$ Triton X-100 diluted 1:5 in cell culture medium. A second set of triplicate wells was used to determine extracellular (leaked) LDH activity, which was expressed as the ratio between the LDH activity in the supernatant and the total $\mathrm{LDH}$ activity obtained from the lysed cells of the same treatment. The $\mathrm{EC}_{20}$ was defined as the concentration of $\mathrm{SiO}_{2}$ NPs resulting in a $20 \%$ decrease (fraction 0.8) in total LDH or a $20 \%$ increase (1.2 fold increase) in extracellular LDH compared to cells treated with the solvent control (distilled water), respectively. At least three independent experiments were performed.

The potential of $\mathrm{SiO}_{2}$ NPs to interfere with the LDH assay by scattering fluorescence or by interfering with LDH or test kit components was assessed. RAW 264.7 cells were seeded in 96-well plates at a density of $2 \times 10^{4}$ cells/well and cultured for $24 \mathrm{~h}$ at $37^{\circ} \mathrm{C}$ in $5 \% \mathrm{CO}_{2}$. The next day, cell culture medium was replaced with fresh cell culture medium containing $100 \mu \mathrm{g} / \mathrm{ml}$ NPs, 10 vol\% distilled water or cell culture medium alone. Simultaneously, 10 $\mu \mathrm{l}$ of $9 \% \mathrm{w} / \mathrm{v}$ Triton $\mathrm{X}-100$ diluted 1:5 in cell culture medium was added, leading to direct 
Iysis of the cells. After $24 \mathrm{~h}$ incubation, LDH activity was determined as described above. The LDH activity of cell culture medium with and without $\mathrm{SiO}_{2} \mathrm{NPs}$ was similar, indicating that the NPs did not interfere with the test (data not shown).

\subsubsection{Acellular generation of reactive oxygen species (ESR)}

Hydroxyl radical formation from $\mathrm{SiO}_{2}$ NPs in an acellular environment was based on a previously published method (van Maanen et al. 1999), with minor modifications. Briefly, solutions of 5,5-dimethyl-1-pyrolline N-oxide (DMPO, Sigma) in nitrogen flushed MilliQ water were purified by charcoal treatment. Stock concentrations of DMPO were determined spectrophotometrically $\left(\varepsilon=7700 \mathrm{M}^{-1} \mathrm{~cm}^{-1}, 234 \mathrm{~nm}\right)$. SiO 2 NPs $(1 \mathrm{mg} / \mathrm{ml})$ in distilled water were incubated with $1 \mathrm{mM} \mathrm{H}_{2} \mathrm{O}_{2}$ and $50 \mathrm{mM}$ of the spin trap DMPO. Samples of this solution were taken up in glass capillaries (100 $\mu \mathrm{l}$, Brand AG, Wertheim, Germany) directly and after an incubation of 15 and $30 \mathrm{~min}$ at $37^{\circ} \mathrm{C}$. After sealing, the capillary was immediately placed in the resonator of the Electron Spin Resonance (ESR) spectrometer. ESR spectra were recorded at room temperature on a Bruker EMX 1273 spectrometer equipped with an ER 4119HS high sensitivity resonator and a $12 \mathrm{~kW}$ power supply operating at $X$ band frequencies. The modulation frequency of the spectrometer was $100 \mathrm{kHz}$. Instrumental conditions for the recorded spectra were as follows: magnetic

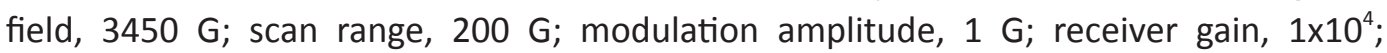
microwave frequency, $9.85 \mathrm{GHz}$; power, $50 \mathrm{~mW}$; time constant, $40.96 \mathrm{~ms}$; scan time, 20.97 s; number of scans, 25. Quantification of the characteristic DMPO-trapped hydroxyl radical signal (4 peaks splitting constant 14.9G, surface pattern 1:2:2:1) was performed by double integration peak surface measurements using the Bruker WIN-EPR spectrum manipulation program.

\subsubsection{Cellular generation of reactive oxygen species $\left(H_{2} D C F-D A\right)$}

The generation of ROS in RAW 264.7 cells after exposure to $\mathrm{SiO}_{2} \mathrm{NPs}_{\text {sas }}$ measured using the $\mathrm{H}_{2}$ DCF-DA assay. Cells were seeded in 96-well tissue culture plates at a density of $2 \times 10^{4}$ cells/well. After $24 \mathrm{~h}$, cell culture medium was removed and cells were exposed to $100 \mu \mathrm{l}$ of NP suspension $(0.1$ to $100 \mu \mathrm{g} / \mathrm{ml}$ ) in cell culture medium containing 10 vol\% FCS for $4 \mathrm{~h}$. Cells exposed to cell culture medium containing $10 \mu \mathrm{g} / \mathrm{ml}$ LPS and $10 \mu \mathrm{g} / \mathrm{ml}$ PMA served as a positive control. After $4 \mathrm{~h}$, the formation of ROS was measured as described elsewhere (Park et al. 2011). The $\mathrm{EC}_{20}$ was defined as the concentration of $\mathrm{SiO}_{2} \mathrm{NPs}$ resulting in a $20 \%$ increase in ROS compared to cells treated with the solvent control (distilled water). Results were obtained from at least three independent experiments.

\subsubsection{Induction of cytokines}

Release of immune related cytokines (IL1 $\alpha$, IL1 $\beta$, IL6, IL10, MIP1 $\alpha$, MIP1 $\beta$, MIP2, IFN $\gamma$, G-CSF and TNF $\alpha$ ) were measured in supernatant of RAW 264.7 cells after 24 h of exposure to $\mathrm{SiO}_{2}$ NPs using a Multiplex system (Bio-Plex Pro Mouse Cytokine kit, BioRad), allowing 
for simultaneous measurement of all 10 cytokines in one sample. Cells were seeded in 96well tissue culture plates at a density of $2 \times 10^{4}$ cells/well. After $24 \mathrm{~h}$, cell culture medium was removed and cells were exposed to $100 \mu \mathrm{l}$ of NP suspension ( 0.3 to $100 \mu \mathrm{g} / \mathrm{ml}$ ) in cell culture medium for $24 \mathrm{~h}$. Subsequently, the supernatant was collected and stored at $-80^{\circ} \mathrm{C}$ until cytokine analysis. Samples were collected from two independent experiments.

Cytokine analysis was performed according to the manufacturer's instructions, with minor modifications. Samples were analyzed both undiluted and diluted 100x with RAW 264.7 cell culture medium. Half of the recommended concentration of anti-cytokine conjugated beads were used, as this proved to be sufficient in past experiments (unpublished results). Concentrations of detection antibody and Streptavidin-PE were adjusted accordingly.

\subsubsection{Data analysis}

For all experiments, data were analyzed using PROAST software version 28.1 (RIVM 2009; Slob 2002). The PROAST software selects the optimal model from the exponential family of the following 5 models:

$$
\begin{array}{ll}
\text { model 1: } & y=a \\
\text { model 2: } & y=a \exp (b x) \\
\text { model 3: } & y=a \exp \left(b x^{d}\right) \\
\text { model 4: } & y=a[c-(c-1) \exp (-b x)] \\
\text { model 5: } & y=a\left[c-(c-1) \exp \left(-b x^{d}\right)\right]
\end{array}
$$

where the level of measured parameter $y$ is a function of nanoparticle concentration $x$.

The model that best describes the data is selected by means of the statistical likelihoodratio criterion (EFSA 2009; RIVM 2009; Slob 2002). Note that when one of the models from the nested family of exponential models describes the data significantly better than the no-response model (= model $1: y=a$ ) this implies that the no-response model is statistically rejected, and an effect of the administered agent is statistically significant. Parameter $a$ reflects the level of measured parameter at concentration zero and parameter $b$ reflects the potency of the administered agent, in this case $\mathrm{SiO}_{2} \mathrm{NPs}$. Parameter $c$ is used for curves that level off. Its value is equal to the factor by which the maximum response is larger (if $c>1$ ) or smaller (if $c<1$ ) than the background response value. Parameter $d$ is a shape parameter, whose default lower bound is one, because values of $d$ smaller than 1 imply that the slope of the curve at dose zero is infinite.

In fitting the model to a combined dataset (all plates and all particle sizes together) the 96-well plate was defined as a covariate for parameter $a$, and, if necessary, as a covariate for the within group variance, thereby taking into account the differences between the plates. For the comparison of the potency of the particles, the particle identity $(11,34 \mathrm{~A}$, $34 \mathrm{~B}, 248$ ) was defined as a covariate for parameter $b$, in this case of NPs of a given identity. In this way, the effect of plates in shifting the dose-response up or down is corrected 
for, while the potential effect of particle size on the dose-response to the left or right (which reflects changes in potency) can be effectively estimated using the results from all plates together. The potential differences between particle sizes was further quantified

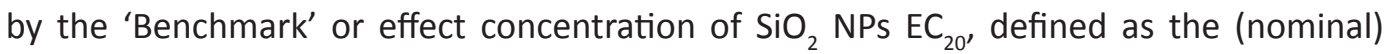
concentration resulting in a $20 \%$ response compared to the solvent control group. The confidence interval of this $\mathrm{EC}_{20}$ value is calculated using the profile likelihood method. A lack of overlap in the $\mathrm{EC}_{20}$ confidence intervals of two particles implies a statistically significant difference between these particles.

Figure 5.1 Dose-response curves of the metabolic conversion of WST-1 in RAW 264.7 macrophages as a function of silica nanoparticle concentration. Data was fitted with the exponential dose-response model: $y=a^{*} \exp (b x)$, and the individual curves were normalized for $a$, i.e. representing fraction of control. Dotted lines represent the $\mathrm{EC}_{20}$ concentrations.

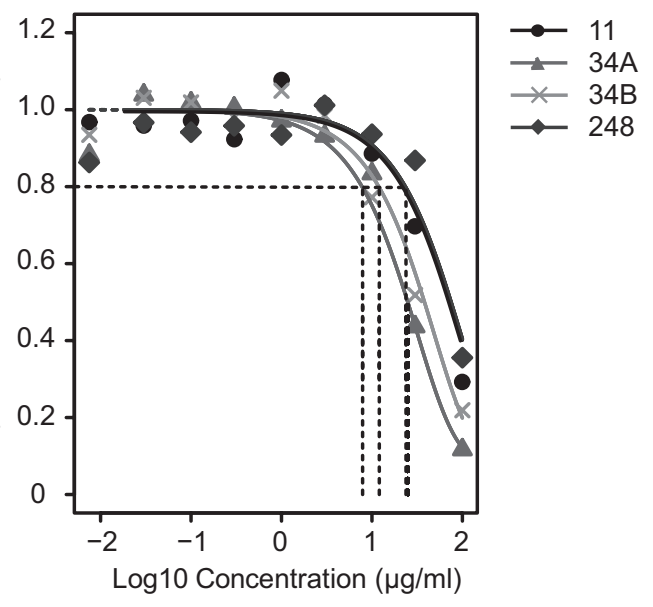

\subsection{RESULTS}

\subsubsection{Cellular metabolic activity}

All tested $\mathrm{SiO}_{2} \mathrm{NPs}$ decreased metabolic activity in a concentration-dependent manner, as measured by reduction of WST-1, with the two $34 \mathrm{~nm} \mathrm{SiO}{ }_{2}$ NPs ( $A$ and B) being most potent (Figure 5.1).

\subsubsection{Cellular membrane integrity}

Total LDH activity (from lysed cells) was not affected by the aggregated $11 \mathrm{~nm}$ NPs and the $248 \mathrm{~nm}$ particles. Exposure to both $34 \mathrm{~nm}$ NPs A and B slightly decreased total LDH activity, although this reduction was less than $20 \%$ compared to solvent control (Figure 5.2). Extracellular LDH enzyme activity (corrected for total LDH activity), is a result of LDH leaking out of cells with membrane damage, and was concentration-dependently increased by all but the $11 \mathrm{~nm} \mathrm{SiO}{ }_{2} \mathrm{NP}$ (Figure 2b). Most membrane damage was induced by the two $34 \mathrm{~nm} \mathrm{SiO}{ }_{2} \mathrm{NPs}$. 

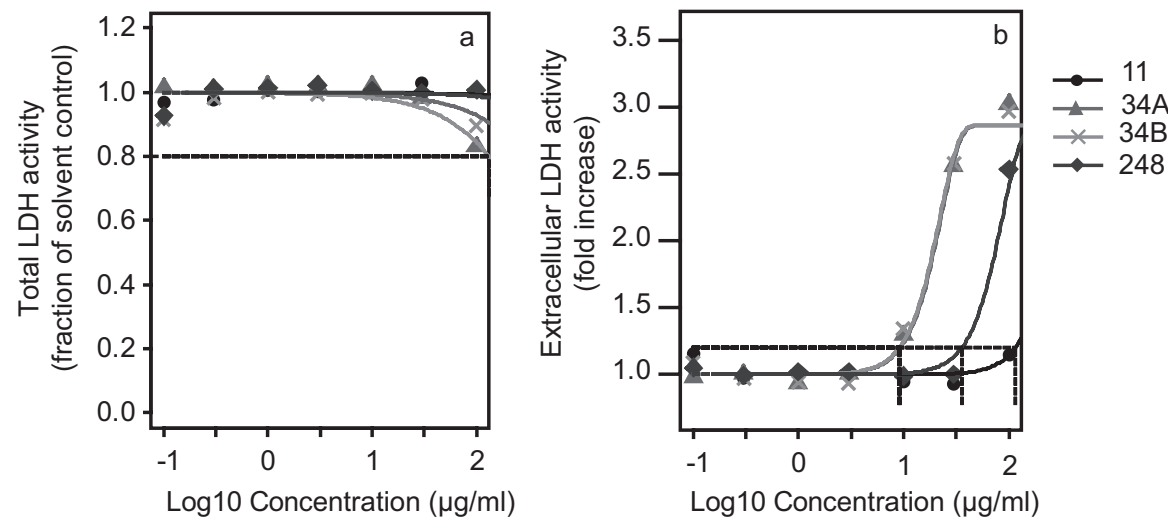

Figure 5.2 Dose-response curves of total LDH activity (a) and extracellular LDH activity (b) of RAW 264.7 macrophages as a function of silica nanoparticle concentration. Data was fitted with the exponential doseresponse model $y=a^{*} \exp (b x)$ for total LDH and the exponential dose-response model $y=a^{*}[c-(c-1) \exp (-$ $\left.b x^{\wedge} d\right)$ ] for extracellular LDH, respectively and the individual curves were normalized for $a$, i.e. representing fraction of control. Dotted lines represent the $\mathrm{EC}_{20}$ concentrations.

\subsubsection{Generation of reactive oxygen species}

$\mathrm{SiO}_{2} \mathrm{NPs}$ were unable to generate ROS in an acellular environment as determined by ESR spectroscopy (data not shown). In contrast, a concentration-dependent ROS generation in RAW 264.7 macrophages was observed after $4 \mathrm{~h}$ exposure to both $34 \mathrm{~nm}$ NPs and, to a lesser extent, the aggregated $11 \mathrm{~nm}$ NPs. The increase was never more than twofold compared to control (Figure 5.3) and the positive control $(10 \mu \mathrm{g} / \mathrm{ml}$ LPS and $10 \mu \mathrm{g} / \mathrm{ml}$ PMA) only induced a three-fold increase in ROS, indicating the assay was not very sensitive. Exposure to $248 \mathrm{~nm}$ particles did not result in an increased ROS generation.

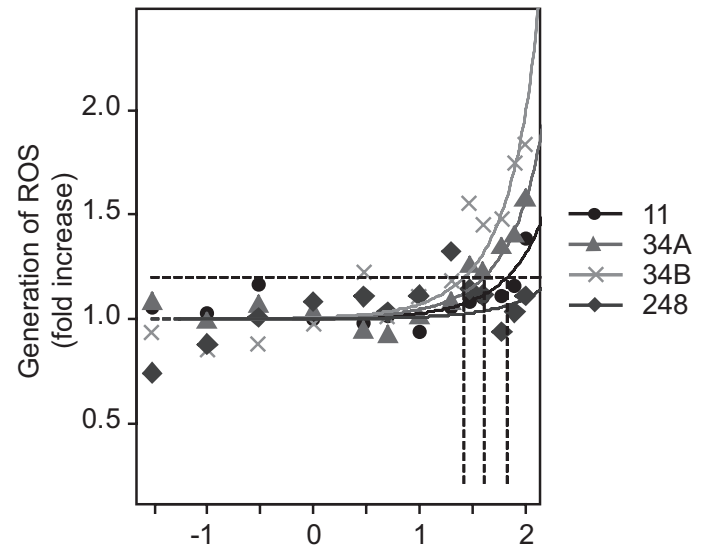

Figure 5.3 Dose-response curves of generation of reactive oxygen species (ROS) in RAW 264.7 macrophages as a function of silica nanoparticle concentration, as measured by the $\mathrm{H}_{2}$ DCF-DA assay. Data was fitted with the exponential dose-response model $y=a^{*} \exp (b x)$ and the individual curves were normalized for $a$, i.e. representing fraction of control. Dotted lines represent the $\mathrm{EC}_{20}$ concentrations. 

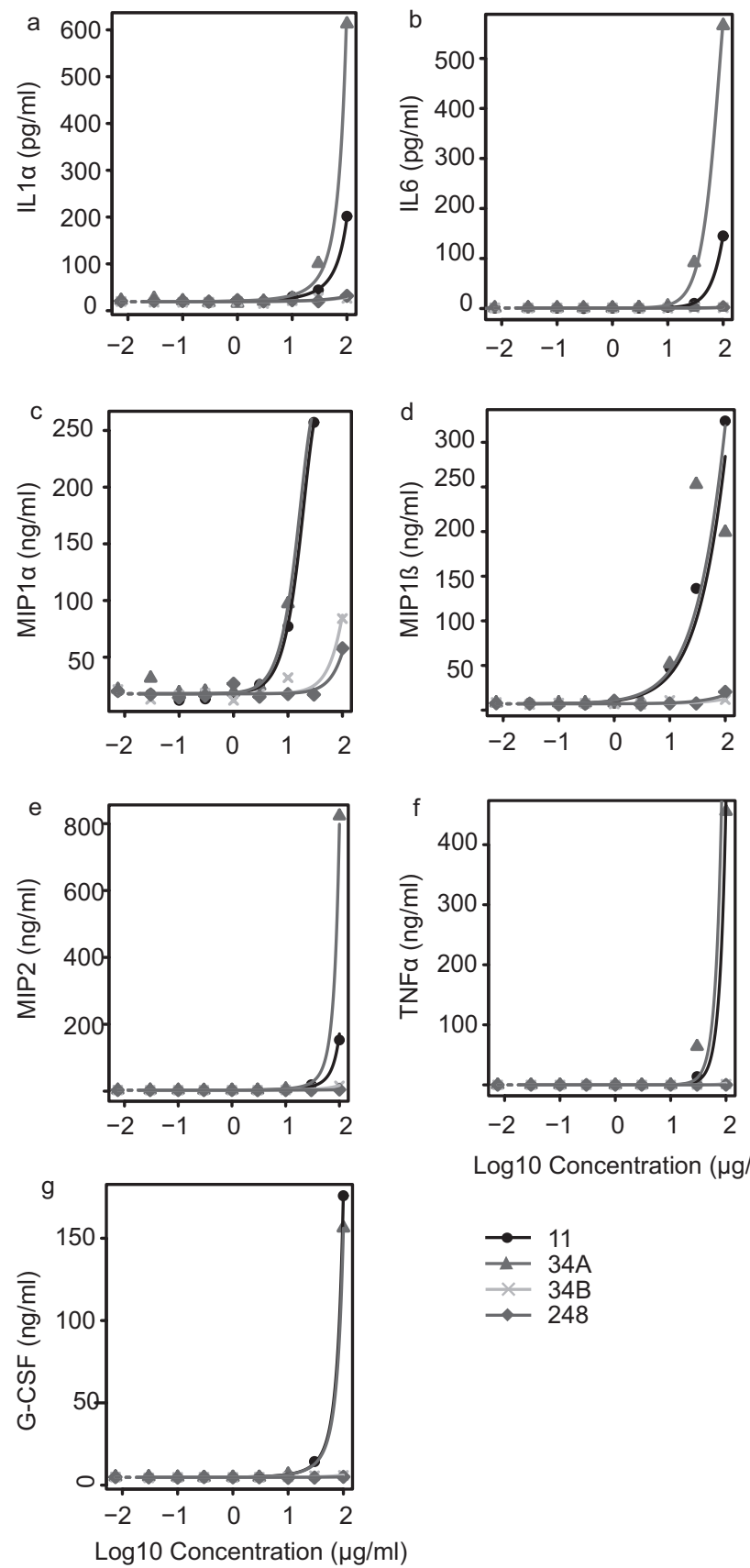

Log10 Concentration $(\mu \mathrm{g} / \mathrm{ml})$

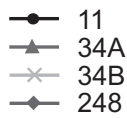

Figure 5.4 Dose-response curves of one experiment showing the induction of IL1 $\alpha$ (a), IL6 (b), MIP1 $\alpha$ (c), MIP1 $\beta$ (d), MIP2 (e) TNF $\alpha$ (f) and G-CSF (g) in RAW 264.7 macrophages as a function of silica nanoparticle concentration. Data was fitted with the optimal model from the exponential family of models, selected using the likelihood-ratio criterion. 


\subsubsection{Induction of cytokines}

All cytokines included in the experiments were induced in a dose-related manner by the aggregated $11 \mathrm{~nm}$ NPs and the 34A NPs after exposure for $24 \mathrm{~h}$. The cytokines IL1 $\beta$, IL10 and IFN $\gamma$ were only marginally increased, i.e. less than 3 -fold by any of the NPs (data not shown), while IL1 $\alpha$ and IL6 were increased up to approximately 500 fold by $34 \mathrm{~A} \mathrm{SiO}_{2} \mathrm{NPs}$ at $100 \mu \mathrm{g} /$ $\mathrm{ml}$ (Figure 5.4). There were large differences in both background levels and magnitude of induction of the cytokines between the two independent experiments, but in spite of this, both experiments clearly demonstrated that the aggregated $11 \mathrm{~nm}$ and the $34 \mathrm{~A} \mathrm{SiO}_{2} \mathrm{NPs}$ were the most potent in inducing all cytokines compared to the $34 \mathrm{~B}$ and $248 \mathrm{~nm} \mathrm{SiO}{ }_{2} \mathrm{NPs}_{\text {. }}$

\subsection{DISCUSSION}

The current study compared the cytotoxicity, reactive potential and inflammation properties of four different $\mathrm{SiO}_{2}$ NPs in RAW 264.7 macrophages. Based on mass concentrations, the extent of the biological responses observed varied between the different $\mathrm{SiO}_{2} \mathrm{NPs}$ despite their similar chemical composition, but identification of the role of np characteristics (size, surface area, aggregation status) in determining the observed biological responses was not straightforward.

We investigated whether the cellular responses to $\mathrm{SiO}_{2} \mathrm{NPs}$ would increase with decreasing particle size due to their increased surface area, which could indicate that cellular responses may be related to surface area rather than mass based concentrations, as has been suggested by results of a number of recent studies (Napierska et al. 2009; Thomassen et al. 2010; Waters et al. 2009). Of the four $\mathrm{SiO}_{2} \mathrm{NPs}$ included in our study, the two $34 \mathrm{~nm}$ NPs were virtually equally potent in decreasing metabolic activity and membrane integrity (Figure 5.5). The larger $248 \mathrm{~nm}$ but also the smallest, $11 \mathrm{~nm} \mathrm{SiO}{ }_{2} \mathrm{NPs}$ were less potent than the $34 \mathrm{~nm}$ NPs, suggesting that the response did not increase with decreasing primary nanoparticle size.

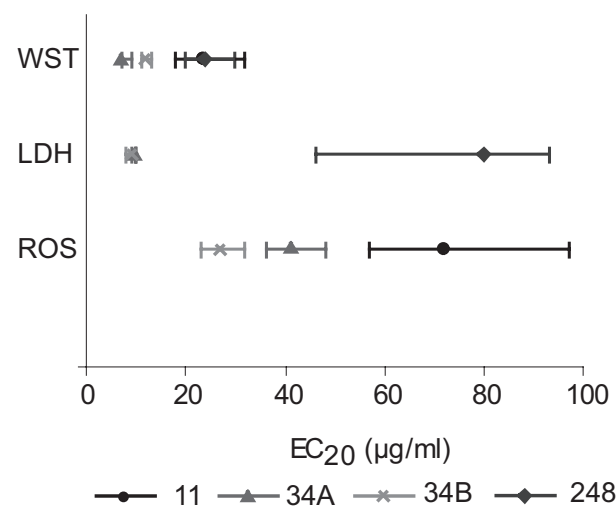

Figure 5.5 Confidence intervals of $\mathrm{EC}_{20}$ concentrations for silica nanoparticles decreasing metabolic activity (WST-1) and membrane integrity (LDH) and inducing reactive oxygen species (ROS) in RAW 264.7 macrophages. 
Our results are in contrast to those of Waters et al. (2009), who used RAW 264.7 macrophages as well as a similar metabolic activity assay to the WST-1 reduction assay used in our study. Based on mass concentrations, Waters et al. found that the mean EC $_{50}$ values for metabolic activity decreased with particle size, while based on surface area, the $\mathrm{EC}_{50}$ for $\mathrm{SiO}_{2} \mathrm{NPs}$ of various sizes and sources was approximately $85 \mathrm{~cm}^{2} / \mathrm{ml}$ for each of the six particles (Waters et al., 2009). Their mathematical conversion of mass to surface area was based on the TEM measured primary diameter of the particles, under the assumptions of spherical shapes, no inner surface area and monodispersity of the $\mathrm{SiO}_{2}$ NPs. While we have previously demonstrated by means of TEM that our $\mathrm{SiO}_{2} \mathrm{NPs}$ were also spherical and contained no significant inner surface area (Park et al. 2009a), all of our particles, but especially the $11 \mathrm{~nm} \mathrm{SiO}{ }_{2}$ NPs, aggregated in water, which persisted when the particles were dispersed in cell culture medium containing serum (Park et al. 2009a). It has been reported recently that the aggregation status of particles may directly affect the exposure concentration and thereby the effects on the cells (Hinderliter et al. 2010). In this respect, it is interesting to note that the relatively well dispersed $248 \mathrm{~nm}$ particles induced the lowest response in nearly all assays performed thus far, including those published previously (Park et al. 2009a; Park et al. 2011).

In addition to affecting exposure concentrations, aggregation can be anticipated to decrease the available surface area, which in turn may affect the cellular responses. For the NPs used in our studies, the mass based $\mathrm{EC}_{50}$ values with confidence intervals calculated for metabolic activity were 75 (59-95), 24 (21-27), 38 (35-42) and 75 (63-91) $\mu \mathrm{g} / \mathrm{ml}$ for the $11 \mathrm{~nm}, 34 \mathrm{~A}, 34 \mathrm{~B}$ and $248 \mathrm{~nm}$ particles, respectively. When we used the hydrodynamic diameter in distilled water for the mathematical conversion to obtain a rough estimate of the surface area corrected for aggregation, the $\mathrm{EC}_{50}$ values for metabolic activity were $20,8,16$ and $8 \mathrm{~cm}^{2} / \mathrm{ml}$ for the $11 \mathrm{~nm}, 34 \mathrm{~A}, 34 \mathrm{~B}$ and $248 \mathrm{~nm}$ particles, respectively. These values are rather low when compared to the $\mathrm{EC}_{50}$ value of $85 \mathrm{~cm}^{2} / \mathrm{ml}$ obtained by Waters et al., (2009), which might be explained by the aggregation of our particles leading to higher exposure concentrations, or by the fact that in the Waters et al. study, no serum was added to the cell culture medium in the cytotoxic response studies. The addition of serum proteins on the surface of the $\mathrm{SiO}_{2}$ NPs in our studies might have enhanced the uptake by the macrophages as a result of the adsorption of opsonins, resulting in an increase in cellular exposure, as has been shown for other NPs (Lesniak et al. 2010; Yang et al. 2010). In a recent study more comparable to ours, i.e. using cell culture medium containing 10 vol\% FCS, a concentration of $10 \mu \mathrm{g} / \mathrm{ml} 30 \mathrm{~nm} \mathrm{SiO}{ }_{2}$ NPs lead to $40 \%$ cytotoxicity in RAW 264.7 (Sohaebuddin et al. 2010), which mathematically converts to approximately $10 \mathrm{~cm}^{2} /$ $\mathrm{ml}$, and is in the same order of magnitude as our results. Either way, in our metabolic activity experiments, both mass and surface area based $\mathrm{EC}_{50}$ values were rather close together, which made it difficult to determine whether or not the cellular responses were related to surface area alone. Reliable methods to study the aggregation status and surface area of $\mathrm{SiO}_{2} \mathrm{NPs}$ in cell culture medium with serum would enhance our understanding of 
the role of nanoparticle size and surface area in cellular responses. This is not a simple task, considering the dynamic nature of NPs and their interaction with proteins in cell culture medium, as shown previously (Park et al. 2009a). A detailed analysis on the nature of the adsorbed serum proteins presented at the NPs surface, which are "read" by the macrophages and other cells, may further elucidate the role of NP surface area in the observed cellular responses (Lynch et al. 2009).

Whatever the role of $\mathrm{SiO}_{2}$ NP size and surface area was in determining the metabolic activity of macrophages, it is not likely to play an important role in the release of cytokines. The aggregated $11 \mathrm{~nm}$ NPs and one of the two $34 \mathrm{~nm}$ NPs (34A) were most potent in inducing the release of cytokines. Despite its similar surface area, the other $34 \mathrm{~nm}$ nanoparticle (34B) was much less potent in inducing cytokines. Others have also found that biological responses to $\mathrm{SiO}_{2} \mathrm{NPs}$ do not consistently increase with a decreasing particle size. Production of IL1 $\beta$ in THP-1 human macrophage like cells was recently shown to increase in response to 1000 $\mathrm{nm} \mathrm{SiO}$, particles, but not in response to smaller particles (Morishige et al. 2010). Similarly, micron-sized $\mathrm{SiO}_{2}$ particles induced increases in TNFa and IL6 production in RAW 264.7 macrophages, while nano-sized $\mathrm{SiO}_{2}$ particles decreased the production of these cytokines compared to controls (Choi et al. 2009). While our studies also found only a marginal increase in IL1 $\beta$ induced by $\mathrm{SiO}_{2} \mathrm{NPs}$, two other studies reported a very significant increase in IL1 $\beta$ in macrophages in response to $\mathrm{SiO}_{2}$ NPs (Choi et al. 2010; Lucarelli et al. 2004). These contradicting results once again underpin that $\mathrm{SiO}_{2} \mathrm{NPs}$ from different sources, despite their identical chemical composition, may induce rather different responses and should not be considered a single chemical entity for risk assessment purposes. Physicochemical characteristics other than particle size, such as surface charge and chemistry, likely play a role in determining cellular responses as well. For example, surface modification with quaternary amines as well as porosity have been shown to affect the level of toxicity of mesoporous $\mathrm{SiO}_{2}$ NPs (Tao et al. 2008; Tao et al. 2009).

Interestingly, our previous studies demonstrated that the $11 \mathrm{~nm}$ and the 34A NPs that were most potent in inducing cytokine release in RAW 264.7 macrophages were also most potent in inhibiting the differentiation of embryonic stem cells (Parket al. 2009a). In addition, the two $34 \mathrm{~nm}$ NPs (34A and 34B) inducing the highest cytotoxic response and generation of ROS in RAW 264.7 macrophages in the current study were previously demonstrated to induce genotoxic effects in MEF-LacZ and 3T3-L1 fibroblasts (Park et al. 2011). In these two studies, we performed qualitative uptake experiments in D3 embryonic stem cells and 3T3 L1 embryonic fibroblasts by means of Transmission Electron Microscopy (Park et al. 2009a; Park et al. 2011). There was no indication of large differences in cellular uptake between the particles in these specific cell types. Even if there were differences in uptake in macrophages in the current study, this would not fully explain why 34A and 34B NPs had similar effects in cytotoxicity assays, but not in cytokine release assays, measured in the same macrophages. It therefore appears that differences in cellular responses between different $\mathrm{SiO}_{2} \mathrm{NPs}$ are best explained by a difference in effects and not by a difference in 
cellular uptake. Furthermore, our collective results demonstrate that biological responses to (aggregated) $\mathrm{SiO}_{2} \mathrm{NPs}$ are not entirely determined by particle size or surface area alone, and the physicochemical characteristics determining the effect of $\mathrm{SiO}_{2} \mathrm{NPs}$ depend on the biological response considered.

It should be noted that both the WST-1 and LDH assays are often used to reflect cytotoxicity, but do not necessarily measure cell death, and some of the effects observed, especially when caused by inhibited cell proliferation, may be reversible. In addition, the level of ROS that was generated by all but the $248 \mathrm{~nm}$ particles may be neutralized by the anti-oxidants present in the cells, diminishing their threat to the cell's viability. Interestingly, none of the $\mathrm{SiO}_{2} \mathrm{NPs}$ were able to generate ROS in an acellular environment. This was also observed for polystyrene particles and confirms that for some ENMs, generation of ROS may only occur following interactions with cellular components (Xia et al. 2006).

Little is known of the fate of NPs after their uptake. Macrophages may act as a sink for the storage of undegradable particles, much like the pigmented cells found in Peyer's Patches in the gut (Powell et al. 2010). Phagocytosis of crystalline and micro-sized amorphous silica particles have been demonstrated to result in lysosomal swelling and rupture, leading to release of cathepsin B in the cytoplasm and activation of NLRP3 inflammasome and caspase-1, which results in cleavage of pro-IL1 $\beta$ to the functional cytokine (Hornung et al. 2008; Morishige et al. 2010; Yazdi et al. 2010). The release of IL1 $\beta$ was demonstrated to be ROS dependent, and ROS formation eventually leads to pro-inflammatory signaling to clear ingested particulate material (Hornung et al. 2008; Morishige et al. 2010). In contrast to micro-sized $\mathrm{SiO}_{2}$ particles, phagocytosis of nano-sized amorphous $\mathrm{SiO}_{2}$ particles did not lead to secretion of significant amounts of IL1 $\beta$ (Morishige et al. 2010). In addition, no detectable destabilization of lysosomal membranes was observed in RAW 264.7 macrophages exposed to $14 \mathrm{~nm}$ amorphous $\mathrm{SiO}_{2}$ NPs (Sohaebuddin et al. 2010). Similarly, in our study, secretion of IL1 $\beta$ after exposure of RAW 264.7 macrophages to amorphous $\mathrm{SiO}_{2} \mathrm{NPs}$ was relatively low, and the release of cytokines was not related to the $\mathrm{SiO}_{2} \mathrm{NPs}^{\prime}$ potential to generate ROS. Collectively, these results suggest that nano-sized amorphous $\mathrm{SiO}_{2}$ particles may not induce the same inflammatory pathways as those observed with crystalline and micro-sized amorphous $\mathrm{SiO}_{2}$ particles.

Despite the low amount of IL1 $\beta$ released in our study, exposure of RAW 264.7 to the aggregated $11 \mathrm{~nm}$ and the $34 \mathrm{~A} \mathrm{SiO}_{2} \mathrm{NPs}$ induced a dose-response related release of various other cytokines, in particular IL1 $\alpha$, IL6, MIP1 $\alpha$, MIP1 $\beta$, MIP2, TNF $\alpha$ and G-CSF, which are all known to have a myriad of functions in the regulation of pro-inflammatory responses. For example, the various MIP proteins function as chemokines attracting monocytes and neutrophils, while IL6 and G-CSF induce differentiation of lymphocytes and granulocytes, respectively. TNF $\alpha$ attracts neutrophils, stimulates phagocytosis and regulates apoptosis, and this latter function has been demonstrated to be important in $\mathrm{SiO}_{2} \mathrm{NP}$ induced cytotoxicity in macrophages (Sohaebuddin et al. 2010). Considering the cytotoxic responses to $\mathrm{SiO}_{2}$ NPs observed in macrophages, IL1 $\alpha$ may be involved in 
sterile inflammatory responses triggered by dying cells (Chen et al. 2007). The induction of a multitude of pro-inflammatory cytokines has also been observed by others studying amorphous $\mathrm{SiO}_{2}$ NPs in macrophages (Choi et al. 2010; Lucarelli et al. 2004; Waters et al. 2009; Wottrich et al. 2004).

Importantly, the induction of cytokines may simply serve to enhance the degradation of these materials (Lucarelli et al. 2004), and as such is not necessarily regarded as a toxic effect. Nevertheless, in case degradation of drug carrying ENMs is faltered, an increased and prolonged stimulation of the macrophages may result in sustained inflammation and damage of the surrounding tissues (Chauhan et al. 2004; Hornung et al. 2008; Yamamoto et al. 2004). This may be counterproductive for a desired anti-inflammatory activity, for example for NPs that are to be used as drug carriers to sites of inflammation. An in vitro

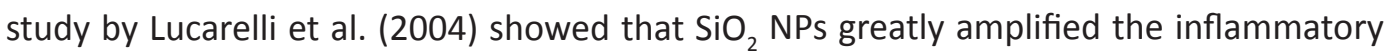
response of both resting and LPS stimulated macrophages, indicating that some $\mathrm{SiO}_{2} \mathrm{NPS}$ may indeed have the undesirable potential to modulate the immune system and direct both naïve and activated macrophages towards pro-inflammatory effector functions. It needs to be noted that most of these in vitro studies, like ours, have been done with immortalized macrophage cell lines, which may be less representative and less sensitive to the effects of NPs than primary cells, such as human monocyte derived macrophages (Oostingh et al. 2011; Pfaller et al. 2009). In general, the cellular responses of macrophages to $\mathrm{SiO}_{2} \mathrm{NPs}$ as tested in vitro occur at relatively high concentrations and their relevance needs to be evaluated in vivo. In pulmonary tissue, amorphous $\mathrm{SiO}_{2}$ particles do not appear to be as persistently inflammatory as their crystalline counterparts (Johnston et al. 2000). The occurrence and persistence of the observed inflammatory response of macrophages to $\mathrm{SiO}_{2}$ NPs in other tissues is yet to be evaluated.

\section{ACKNOWLEDGMENTS}

This work was funded by the EU FP6 project Nanolnteract (NMP4-CT-2006-033231), and via the SFI SRC BioNanolnteract ([07 SRC B1155]). The authors thank Wijtske Annema, Nick van Oijen, Henny Verharen and Jolanda Vermeulen for their technical assistance. 


\section{REFERENCES}

Agasti SS, Rana S, Park MH, Kim CK, You CC, Rotello VM. 2010. Nanoparticles for detection and diagnosis. Adv Drug Deliv Rev 62(3):316-28.

Akhtar MJ, Ahamed M, Kumar S, Siddiqui H, Patil G, Ashquin M, Ahmad I. 2010. Nanotoxicity of pure silica mediated through oxidant generation rather than glutathione depletion in human lung epithelial cells. Toxicology 276(2):95-102.

Barnes CA, Elsaesser A, Arkusz J, Smok A, Palus J, Lesniak A, Salvati A, Hanrahan JP, Jong WH, Dziubaltowska $E$ and others. 2008. Reproducible comet assay of amorphous silica nanoparticles detects no genotoxicity. Nano Lett 8(9):3069-74.

Carlson C, Hussain SM, Schrand AM, Braydich-Stolle LK, Hess KL, Jones RL, Schlager JJ. 2008. Unique cellular interaction of silver nanoparticles: size-dependent generation of reactive oxygen species. J Phys Chem B 112(43):13608-19.

Chauhan V, Breznan D, Goegan P, Nadeau D, Karthikeyan S, BrookJR, Vincent R. 2004. Effects of ambient air particles on nitric oxide production in macrophage cell lines. Cell Biol Toxicol 20(4):221-39.

Chen CJ, Kono H, Golenbock D, Reed G, Akira S, Rock KL. 2007. Identification of a key pathway required for the sterile inflammatory response triggered by dying cells. Nat Med 13(7):851-6.

Chen Y, Xue Z, Zheng D, Xia K, Zhao Y, Liu T, Long Z, Xia J. 2003. Sodium chloride modified silica nanoparticles as a non-viral vector with a high efficiency of DNA transfer into cells. Curr Gene Ther 3(3):273-9.

Choi J, Zhang Q, Reipa V, Wang NS, Stratmeyer ME, Hitchins VM, Goering PL. 2009. Comparison of cytotoxic and inflammatory responses of photoluminescent silicon nanoparticles with silicon micron-sized particles in RAW 264.7 macrophages. J Appl Toxicol 29(1):52-60.

Choi J, Zheng Q, Katz HE, Guilarte TR. 2010. Silica-based nanoparticle uptake and cellular response by primary microglia. Environ Health Perspect 118(5):589-95.

De Jong WH, Hagens WI, Krystek P, Burger MC, Sips AJ, Geertsma RE. 2008. Particle size-dependent organ distribution of gold nanoparticles after intravenous administration. Biomaterials 29(12):1912-9.

Dutta D, Sundaram SK, Teeguarden JG, Riley BJ, Fifield LS, Jacobs JM, Addleman SR, Kaysen GA, Moudgil BM, Weber TJ. 2007. Adsorbed proteins influence the biological activity and molecular targeting of nanomaterials. Toxicol Sci 100(1):303-15.

EFSA. 2009. Guidance of the Scientific Committee on a request from EFSA on the use of the benchmark dose approach in risk assessment. The EFSA journal 1150:1-72.

Fischer HC, Chan WC. 2007. Nanotoxicity: the growing need for in vivo study. Curr Opin Biotechnol 18(6):565-571.

Hamoir J, Nemmar A, Halloy D, Wirth D, Vincke G, Vanderplasschen A, Nemery B, Gustin P. 2003. Effect of polystyrene particles on lung microvascular permeability in isolated perfused rabbit lungs: role of size and surface properties. Toxicol Appl Pharmacol 190(3):278-85.

Hinderliter PM, Minard KR, Orr G, Chrisler WB, Thrall BD, Pounds JG, Teeguarden JG. 2010. ISDD: A computational model of particle sedimentation, diffusion and target cell dosimetry for in vitro toxicity studies. Part Fibre Toxicol 7(1):36.

Hornung V, Bauernfeind F, Halle A, Samstad EO, Kono H, Rock KL, Fitzgerald KA, Latz E. 2008. Silica crystals and aluminum salts activate the NALP3 inflammasome through phagosomal destabilization. Nat Immunol 9(8):847-56. 
Jarzyna PA, Gianella A, Skajaa T, Knudsen G, Deddens LH, Cormode DP, Fayad ZA, Mulder WJ. 2010. Multifunctional imaging nanoprobes. Wiley Interdiscip Rev Nanomed Nanobiotechnol 2(2):13850.

Johnston CJ, Driscoll KE, Finkelstein JN, Baggs R, O'Reilly MA, Carter J, Gelein R, Oberdorster G. 2000. Pulmonary chemokine and mutagenic responses in rats after subchronic inhalation of amorphous and crystalline silica. Toxicol Sci 56(2):405-13.

Kang JL, Moon C, Lee HS, Lee HW, Park EM, Kim HS, Castranova V. 2008. Comparison of the biological activity between ultrafine and fine titanium dioxide particles in RAW 264.7 cells associated with oxidative stress. J Toxicol Environ Health A 71(8):478-85.

Lankveld DP, Oomen AG, Krystek P, Neigh A, Troost-de Jong A, Noorlander CW, Van Eijkeren JC, Geertsma RE, De Jong WH. 2010. The kinetics of the tissue distribution of silver nanoparticles of different sizes. Biomaterials 31(32):8350-8361.

Lesniak A, Campbell A, Lynch I, Salvati A, Dawson KA. 2010. Serum heat inactivation affects protein corona composition and nanoparticle uptake. Biomaterials 31(36):9511-9518.

Lucarelli M, Gatti AM, Savarino G, Quattroni P, Martinelli L, Monari E, Boraschi D. 2004. Innate defence functions of macrophages can be biased by nano-sized ceramic and metallic particles. Eur Cytokine Netw 15(4):339-46.

Lynch I, Salvati A, Dawson KA. 2009. Protein-nanoparticle interactions: What does the cell see? Nat Nanotechnol 4(9):546-7.

Morishige T, Yoshioka Y, Inakura H, Tanabe A, Yao X, Narimatsu S, Monobe Y, Imazawa T, Tsunoda S, Tsutsumi $Y$ and others. 2010. The effect of surface modification of amorphous silica particles on NLRP3 inflammasome mediated IL-1beta production, ROS production and endosomal rupture. Biomaterials 31(26):6833-42.

Moulari B, Pertuit D, Pellequer Y, Lamprecht A. 2008. The targeting of surface modified silica nanoparticles to inflamed tissue in experimental colitis. Biomaterials 29(34):4554-60.

Nabeshi H, Yoshikawa T, Matsuyama K, Nakazato Y, Arimori A, Isobe M, Tochigi S, Kondoh S, Hirai T, Akase T and others. 2010. Size-dependent cytotoxic effects of amorphous silica nanoparticles on Langerhans cells. Pharmazie 65(3):199-201.

Napierska D, Thomassen LC, Rabolli V, Lison D, Gonzalez L, Kirsch-Volders M, Martens JA, Hoet PH. 2009. Size-dependent cytotoxicity of monodisperse silica nanoparticles in human endothelial cells. Small 5(7):846-53.

Oostingh GJ, Casals E, Italiani P, Colognato R, Stritzinger R, Ponti J, Pfaller T, Kohl Y, Ooms D, Favilli $\mathrm{F}$ and others. 2011. Problems and challenges in the development and validation of human cellbased assays to determine nanoparticle-induced immunomodulatory effects. Part Fibre Toxicol $8(1): 8$.

Park MVDZ, Annema W, Salvati A, Lesniak A, Elsaesser A, Barnes C, McKerr G, Howard CV, Lynch I, Dawson KA and others. 2009a. In vitro developmental toxicity test detects inhibition of stem cell differentiation by silica nanoparticles. Toxicol Appl Pharmacol 240:108-116.

Park MVDZ, Lankveld DPK, van Loveren H, de Jong W. 2009b. The status of in vitro toxicity studies in risk assessment of nanomaterials Nanomedicine 4(6):669-685.

Park MVDZ, Verharen HW, Zwart E, Hernandez LG, van Benthem J, Elsaesser A, Barnes C, McKerr G, Howard CV, Salvati A and others. 2011. Genotoxicity evaluation of amorphous silica nanoparticles of different sizes using the micronucleus and the plasmid lacZ gene mutation assay. Nanotoxicology 5:168-81. 
Pfaller T, Puntes VF, Casals E, Dusch I A, Oostingh GJ. 2009. In vitro investigation of immunomodulatory effects caused by engineered inorganic nanoparticles - the impact of experimental design and cell choice. Nanotoxicology 3(1):46-59.

Powell JJ, Faria N, Thomas-McKay E, Pele LC. 2010. Origin and fate of dietary nanoparticles and microparticles in the gastrointestinal tract. J Autoimmun 34(3):J226-33.

RIVM. 2009. PROAST: Software for dose-response modeling and benchmark dose analysis. Available from: www.proast.nl.

Roy I, Stachowiak MK, Bergey EJ. 2008. Nonviral gene transfection nanoparticles: function and applications in the brain. Nanomedicine 4(2):89-97.

Sadauskas E, Wallin H, Stoltenberg M, Vogel U, Doering P, Larsen A, Danscher G. 2007. Kupffer cells are central in the removal of nanoparticles from the organism. Part Fibre Toxicol 4:10.

Sayes CM, Reed KL, Warheit DB. 2007. Assessing toxicity of fine and nanoparticles: comparing in vitro measurements to in vivo pulmonary toxicity profiles. Toxicol Sci 97(1):163-80.

Shi Y, Yadav S, Wang F, Wang H. 2010. Endotoxin promotes adverse effects of amorphous silica nanoparticles on lung epithelial cells in vitro. J Toxicol Environ Health A 73(11):748-56.

Slob W. 2002. Dose-response modeling of continuous endpoints. Toxicol Sci 66(2):298-312.

Sohaebuddin SK, Thevenot PT, Baker D, Eaton JW, Tang L. 2010. Nanomaterial cytotoxicity is composition, size, and cell type dependent. Part Fibre Toxicol 7(1):22.

Stöber W, Fink A, Bohn E. 1968. Controlled growth of monodisperse silica spheres in the micron size range. J. Colloid Interface Sci. 26(1):62-9.

Stone V, Johnston H, Schins RP. 2009. Development of in vitro systems for nanotoxicology: methodological considerations. Crit Rev Toxicol 39(7):613-26.

Tao Z, Morrow MP, Asefa T, Sharma KK, Duncan C, Anan A, Penefsky HS, Goodisman J, Souid AK. 2008. Mesoporous silica nanoparticles inhibit cellular respiration. Nano Lett 8(5):1517-26.

Tao Z, Toms BB, Goodisman J, Asefa T. 2009. Mesoporosity and functional group dependent endocytosis and cytotoxicity of silica nanomaterials. Chem Res Toxicol 22(11):1869-80.

Thomassen LC, Aerts A, Rabolli V, Lison D, Gonzalez L, Kirsch-Volders M, Napierska D, Hoet PH, Kirschhock CE, Martens JA. 2010. Synthesis and characterization of stable monodisperse silica nanoparticle sols for in vitro cytotoxicity testing. Langmuir 26(1):328-35.

Ulbrich W, Lamprecht A. 2010. Targeted drug-delivery approaches by nanoparticulate carriers in the therapy of inflammatory diseases. J R Soc Interface 7 Suppl 1:S55-66.

van Maanen JM, Borm PJ, Knaapen A, van Herwijnen M, Schilderman PA, Smith KR, Aust AE, Tomatis $M$, Fubini B. 1999. In vitro effects of coal fly ashes: hydroxyl radical generation, iron release, and DNA damage and toxicity in rat lung epithelial cells. Inhal Toxicol 11(12):1123-41.

Veranth JM, Kaser EG, Veranth MM, Koch M, Yost GS. 2007. Cytokine responses of human lung cells (BEAS-2B) treated with micron-sized and nanoparticles of metal oxides compared to soil dusts. Part Fibre Toxicol 4:2.

Waters KM, Masiello LM, Zangar RC, Tarasevich BJ, Karin NJ, Quesenberry RD, Bandyopadhyay S, Teeguarden JG, Pounds JG, Thrall BD. 2009. Macrophage responses to silica nanoparticles are highly conserved across particle sizes. Toxicol Sci 107(2):553-69.

Wottrich R, Diabate S, Krug HF. 2004. Biological effects of ultrafine model particles in human macrophages and epithelial cells in mono- and co-culture. Int J Hyg Environ Health 207(4):35361. 
Xia T, Kovochich M, Brant J, Hotze M, Sempf J, Oberley T, Sioutas C, Yeh JI, Wiesner MR, Nel AE. 2006. Comparison of the abilities of ambient and manufactured nanoparticles to induce cellular toxicity according to an oxidative stress paradigm. Nano Lett 6(8):1794-807.

Yamamoto A, Honma R, Sumita M, Hanawa T. 2004. Cytotoxicity evaluation of ceramic particles of different sizes and shapes. J Biomed Mater Res A 68(2):244-56.

Yang A, Liu W, Li Z, Jiang L, Xu H, Yang X. 2010. Influence of polyethyleneglycol modification on phagocytic uptake of polymeric nanoparticles mediated by immunoglobulin $\mathrm{G}$ and complement activation. J Nanosci Nanotechnol 10(1):622-8.

Yazdi AS, Guarda G, Riteau N, Drexler SK, Tardivel A, Couillin I, Tschopp J. 2010. Nanoparticles activate the NLR pyrin domain containing 3 (NIrp3) inflammasome and cause pulmonary inflammation through release of IL-1alpha and IL-1beta. Proc Natl Acad Sci U S A 107(45):19449-54. 




\section{CHAPTER 6}

\section{THE EFFECT OF PARTICLE SIZE ON THE CYTOTOXICITY, INFLAMMATION, DEVELOPMENTAL TOXICITY AND GENOTOXICITY OF SILVER NANOPARTICLES}

${ }^{1}$ Department of Toxicogenomics, Maastricht University, PO Box 616, 6200 MD, Maastricht, the Netherlands,

${ }^{2}$ Laboratory for Health Protection Research, National Institute for Public Health and the Environment (RIVM), PO Box 1, 3720 BA, Bilthoven, the Netherlands ${ }^{3}$ nanoComposix, Inc., 4878 Ronson Court Suite K, San Diego, CA 92111, United States 



\section{ABSTRACT}

Silver nanoparticles are of interest to be used as antimicrobial agents in wound dressings and coatings in medical devices, but potential adverse effects have been reported in the literature. The most pronounced effect of silver nanoparticles and the role of particle size in determining these effects, also in comparison to silver ions, are largely unknown. Effects of silver nanoparticles of different sizes $(20,80,113 \mathrm{~nm})$ were compared in in vitro assays for cytotoxicity, inflammation, genotoxicity and developmental toxicity. Silver nanoparticles induced effects in all endpoints studied, but effects on cellular metabolic activity and membrane damage were most pronounced. In all toxicity endpoints studied, silver nanoparticles of $20 \mathrm{~nm}$ were more toxic than the larger nanoparticles. In L929 fibroblasts, but not in RAW 264.7 macrophages, $20 \mathrm{~nm}$ silver nanoparticles were more cytotoxic than silver ions. Collectively, these results indicate that effects of silver nanoparticles on different toxic endpoints may be the consequence of their ability to inflict cell damage. In addition, the potency of silver in the form of nanoparticles to induce cell damage compared to silver ions is cell type and size-dependent.

\subsection{INTRODUCTION}

Nanotechnology allows for an efficient exploitation of the antimicrobial properties of silver $(\mathrm{Ag})$ by using silver in the form of nanoparticles (NPs). These are used in applications such as preservatives in cosmetics, textiles, water purification systems, coatings in catheters and wound dressings. The anticipated widespread exposure to Ag NPs in the near future has prompted governmental bodies and the public to raise questions about the safety of such applications (Christensen et al. 2010; Schrand et al. 2010; Wijnhoven et al. 2009). In response, many studies investigating the effects of various types of Ag NPs in different test systems are now emerging in the scientific literature.

A recent kinetic and distribution study in rats with Ag NPs of three different sizes demonstrated that after 28 days of intravenous administration, all particles mainly distributed to organs containing high numbers of phagocytosing cells, such as liver, spleen, and lung (Lankveld et al. 2010). This is not surprising, as these cell types have an important function in clearing the body of particulate matter. At the same time, a number of studies have shown that Ag NPs may induce cytotoxicity in phagocytosing cells, such as mouse peritoneal macrophages, but also human monocytes (Foldbjerg et al. 2009; Park et al. 2010; Shavandi et al. 2011; Soto et al. 2007). It has been suggested that the cytotoxic effects were induced by reactive oxygen species (ROS) resulting in cellular apoptosis, at least at low concentrations and short incubation times (Braydich-Stolle et al. 2005; Carlson et al. 2008; Foldbjerg et al. 2009; Nishanth et al. 2011; Piao et al. 2011). The production of ROS has also been implicated in DNA damage caused by Ag NPs, which was reported in a number of in vitro studies (Ahamed et al. 2008; AshaRani et al. 2009; Foldbjerg et al. 2010; Hackenberg et al. 2011; Kawata et al. 2009). 
The effects on markers of inflammation are much less understood, with some studies reporting an anti-inflammatory effect of Ag NPs by suppressing cytokine production in post-operative adhesion or burn wound models and in stimulated human peripheral blood mononuclear cells (Bhol and Schechter 2007; Shin et al. 2007; Tian et al. 2007; Wong et al. 2009) while others report the induction of pro-inflammatory cytokines in rat peritoneal and alveolar macrophages, human mesenchymal stem cells and in an in vitro blood brain barrier model (Carlson et al. 2008; Hackenberg et al. 2011; Nishanth et al. 2011; Park et al. 2010; Trickler et al. 2010).

Another reported effect of Ag NPs is the induction of various morphological malformations in developing zebra fish embryos (Asharani et al. 2011; Bar-llan et al. 2009; Lee et al. 2007) and impairing development and implantation of mouse blastocysts (Li et al. 2010).

For risk assessment purposes, it is useful to know which of these reported effects of $\mathrm{Ag}$ NPs is the most relevant for further investigation, i.e. whether one effect is more pronounced than another at similar exposure concentrations. Comparison across studies is complicated, as materials of different sources, sizes, coatings and manufacturing processes have been studied. Another important question from the view of risk assessors is: How do the effects of Ag NPs compare to those of other forms of silver such as ionic silver?
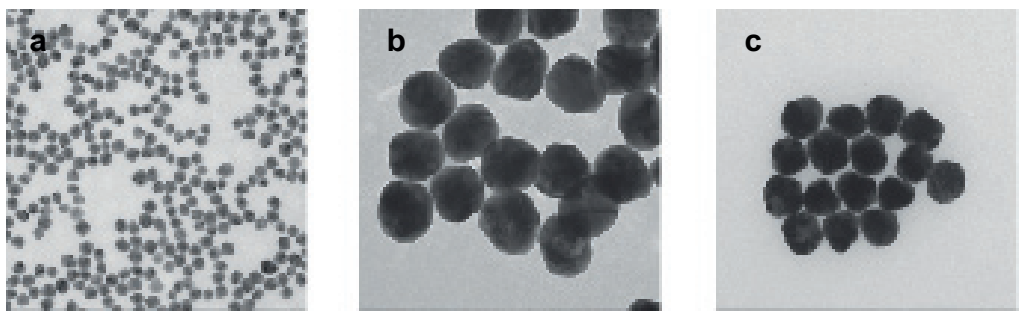

Figure 6.1 Transmission Electron Micrographs of silver nanoparticles of $20 \mathrm{~nm}(\mathrm{a}), 80 \mathrm{~nm}$ (b) and $113 \mathrm{~nm}$ (c).

The aim of this study was to investigate the role of NP size in these effects, using wellcharacterized Ag NPs of the same source in assays for various toxicity endpoints and compare these findings to effects reported in the literature. Cytotoxicity was investigated in two commonly used cell types that may be exposed to NPs: L929 murine fibroblasts and RAW 264.7 murine macrophages, and effects of Ag NPs were compared to those of $\mathrm{Ag}$ in ionic form. In addition, in view of the phagocytic and immune-related function of macrophages, we investigated the role of Ag NP size on the generation of ROS and on parameters of inflammation. Lastly, the role of Ag NP size was investigated in assays for developmental toxicity and genotoxicity in mouse embryonic stem cells and embryonic fibroblasts, respectively. 


\subsection{MATERIALS AND METHODS}

\subsubsection{Silver nanoparticles}

Ag NPs of average nominal diameters of 20,80 , and $110 \mathrm{~nm}$ were provided by nanoComposix, Inc. (San Diego, CA, USA). The NPs were synthesized by aqueous reduction synthesis from Ag salts and then purified $20 \mathrm{x}$ in a $4 \mathrm{mM}$ phosphate buffer ( $\mathrm{pH} 7.4$, mono- and di-sodium phosphate) and then concentrated. NPs were characterized for physicochemical properties, purity of residual synthesis products, and concentration prior to synthesis and after dilution in phosphate buffer. Table 6.1 provides characterization information for NPs.

\begin{tabular}{llll} 
Nominal Diameter $(\mathrm{nm})$ & $\mathbf{2 0}$ & $\mathbf{8 0}$ & $\mathbf{1 1 0}$ \\
\hline TEM Diameter $(\mathrm{nm} \pm 1 \mathrm{SD})$ & $20.3 \pm 1.9$ & $79.8 \pm 5.1$ & $112.6 \pm 7.8$ \\
DLS Size (nm \pm PDI Width) & $27.0 \pm 10.8$ & $79 \pm 25.2$ & $111.6 \pm 29.9$ \\
Crystalline Structure & amorphous & amorphous & amorphous \\
Zeta Potential (mV $\pm 1 \mathrm{SD})$ & $-47.1 \pm 1.9$ & $-49.7 \pm 1.8$ & $-54.5 \pm 1.8$ \\
Mass Concentration (mg/L) & 4740 & 5000 & 2170 \\
Mean Particle Surface Area & $1.31 \times 10^{3}$ & $2.01 \times 10^{4}$ & $4.00 \times 10^{4}$ \\
$\left(\mathrm{~nm}^{2} /\right.$ particle) & & & \\
Residual formaldehyde (mg/L) & $<0.001$ & $<0.001$ & $<0.001$ \\
\hline
\end{tabular}

Table 6.1 Physicochemical characteristics of silver nanoparticles. PDI: polydispersity index; DLS: dynamic light scattering.

Transmission electron microscopy (TEM) was performed on a JEOL 1010 TEM by fixation on a Formvar carbon-coated copper grid (200 mesh) using an alcohol and deionized water mixture (Ted Pella, Redding, CA) (Figure 6.1). Primary particle size was measured using imaging software (Image J) across the diameter of the particles. Particles were approximately spherical, and therefore, the diameter measurements were performed at random. Mean surface area and number of particles were calculated based on mass concentration and average TEM diameter. Arithmetic mean and standard deviation of primary particle diameters are based on normal distributions.

Materials were tested for residual formaldehyde concentration which were below detection limits (<1 ppb) for formaldehyde via modified EPA SW846 Method 8315A. Product concentration was evaluated using a Thermo Element X-Series II inductively couple plasma quadrapole mass spectrometer (ICP-MS). Samples were digested in concentrated nitric acid and then diluted with deionized water and internal standard (1 ppb Indium, Spex CertiPrep Standard). NP size distribution was determined for the synthesized samples by diluting samples in deionized water to approximately 1 OD and quantified using a Malvern Zeta Sizer (Worchestershire, UK). Hydrodynamic diameter was calculated based on the average of 10 runs of the intensity weighted Z-average performed at $25^{\circ} \mathrm{C}$ using the cumulative fit function performed in triplicate. 


\subsubsection{Cell culture}

The murine peritoneal macrophage cell line RAW 264.7 was obtained from American Type Culture Collection (ATCC, Rockville, USA) and routinely cultured at $37^{\circ} \mathrm{C}$ and $5 \% \mathrm{CO}_{2}$ in Dulbecco's Modified Eagle Medium (DMEM/F12 + GlutaMAX -1, Gibco 31331, Breda, The Netherlands) supplemented with 10 vol\% Foetal Calf Serum (FCS, Gibco 16010), PenicillinStreptomycin solution (100 U/mL / $100 \mu \mathrm{g} / \mathrm{mL}$, Gibco 15040), and $1 \mathrm{mM}$ sodium pyruvate (Gibco 11360).

L929 mouse fibroblasts were purchased from ATCC (Rockville, USA). Cells were routinely cultured at $37^{\circ} \mathrm{C}$ and $5 \% \mathrm{CO}_{2}$ in DMEM (Gibco 61965) supplemented with $10 \%$ FCS (Gibco 16010), (100 U/mL / $100 \mu \mathrm{g} / \mathrm{mL}$, Gibco 15040), and 1 vol\% Non-essential amino acids (NEAA, Gibco 11140).

The D3 murine embryonic stem cell line was purchased from ATTC. Cells were maintained in DMEM (Gibco, 41965) supplemented with 20 vol\% FCS (HyClone, Logan, USA), 2 mM L-glutamine (Gibco, 25030), Penicillin-Streptomycin solution ( $50 \mathrm{U} / \mathrm{ml} / 50 \mu \mathrm{g} /$ $\mathrm{ml}$, Gibco, 15070), 1 vol\% NEAA (Gibco, 11140) and $0.1 \mathrm{mM} \beta$-mercaptoethanol (SigmaAldrich, M6250, Schnelldorf, Germany) in the presence of $1000 \mathrm{U} / \mathrm{ml}$ murine Leukemia Inhibiting Factor (mLIF; ESGRO, Chemicon, Billerica, USA) in a humidified atmosphere of $5 \% \mathrm{CO}_{2}$ and $37^{\circ} \mathrm{C}$. The addition of $\mathrm{mLIF}$ serves to inhibit spontaneous differentiation of the embryonic stem cells into major embryonic tissues. The D3 embryonic stem cells were routinely cultured in 35×10 mm culture dishes (Corning, Sigma-Aldrich, Schnelldorf, Germany) coated with a 0.1 vol\% gelatin solution and subcultivated using non-enzymatic cell dissociation buffer (Gibco, 13150) upon reaching 60-80\% confluence. NP exposure experiments were performed using D3 cells between passages 11 and 25 .

Mouse embryonic fibroblasts (MEF-LacZ) were isolated from 13.5 day old embryos from transgenic C57BL/6 mice containing multiple copies of the pUR288 plasmid with the bacterial lacZ gene as a reporter gene in their genome, as described previously (Mahabir et al. 2009). Aliquots of $3 \times 10^{6}$ cells in $1 \mathrm{ml}$ cell culture medium were kept at $-80{ }^{\circ} \mathrm{C}$ for at least $24 \mathrm{~h}$ and were then stored in liquid nitrogen. Before the start of the experiment, cells were thawed and cultured for one week in $175 \mathrm{~cm}^{2}$ tissue culture flasks at $37^{\circ} \mathrm{C}$ under $10 \%$ $\mathrm{CO}_{2}$ and $3 \% \mathrm{O}_{2}$, undergoing 1 passage. The cell culture medium used for both cell culture and experiments with MEF-LacZ consisted of DMEM (Gibco 31885) supplemented with 1 vol\% Modified Eagles Medium NEAA (Gibco 11140), Penicillin-Streptomycin solution (50 $\mathrm{U} / \mathrm{ml} / 50 \mu \mathrm{g} / \mathrm{ml}$, Gibco, 15070), and 10 vol\% Fetal Bovine Serum (FBS, Biocell).

\subsubsection{Metabolic activity (WST-1)}

Cell metabolic activity of RAW 264.7, D3 and L929 cells was evaluated using the WST-1 Cell Proliferation Reagent (Roche, Almere, the Netherlands). The metabolic conversion of WST1 by the cells and the ability of Ag NPs to scatter or absorb light or to interfere with the WST1 reagent were assessed in 96-well plates according to methods described earlier (Park et al. 2009a; Park et al. 2011). Briefly, cells were exposed to Ag NPs for 24h (RAW 264.7 and 
L929) or 10 days (D3), and subsequently incubated with WST-1 reagent for 3h. Absorbance was measured using a SpectraMax ${ }^{\circledR} 190$ scanning multiwell spectrophotometer (Molecular Devices, Sunnyvale, USA) at a wavelength of $440 \mathrm{~nm}$ and a reference wavelength of 620 $\mathrm{nm}$. The absorbance of Ag NPs in tissue culture medium, measured in the absence of cells, was subtracted from the total absorbance of the NP treated cells.

\subsubsection{Membrane integrity (LDH)}

Cell membrane integrity of RAW 264.7 and $\mathrm{L} 929$ was evaluated by determining the activity of lactate dehydrogenase (LDH) leaking out of the cell, using the CytoTox-ONE ${ }^{\mathrm{TM}}$ Homogeneous Membrane Integrity Assay (Promega, Leiden, The Netherlands) according to manufacturer's specifications. Cells were exposed to Ag NPs in the same way as for the WST-1 assay. At the end of the $24 \mathrm{~h}$ exposure period, 96-well plates were equilibrated to room temperature and LDH activity was measured. Extracellular LDH was corrected for total LDH activity in cells (measured in wells with lysed cells) undergoing the same treatment, to avoid false negative results in cases where the NP treatment caused an inhibition of cell proliferation and as such caused a lower amount of LDH to be available to leak out of damaged cells (Park et al. 2009b; Stone et al. 2009).

\subsubsection{Acellular reactive oxygen species}

The potential of the Ag NPs to generate hydroxyl radical formation was evaluated using an Electron Spin Resonance spectroscopy (ESR) method based on a previously published method (van Maanen et al. 1999), with minor modifications. Solutions of 5,5-dimethyl-1pyrolline $\mathrm{N}$-oxide (DMPO, Sigma) in nitrogen flushed MilliQ water were purified by charcoal treatment. Stock concentrations of DMPO were determined spectrophotometrically $(\varepsilon=$ $\left.7700 \mathrm{M}^{-1} \mathrm{~cm}^{-1}, 234 \mathrm{~nm}\right)$. Ag NPs $\left(1 \mathrm{mg} / \mathrm{ml}\right.$ ) were incubated with $1 \mathrm{mM} \mathrm{H}_{2} \mathrm{O}_{2}$ and $50 \mathrm{mM}$ of the spin trap DMPO. Samples of this solution were taken up in glass capillaries ( $100 \mu$ l, Brand AG, Wertheim, Germany) directly and after an incubation of 15 and 30 min at $37^{\circ} \mathrm{C}$. After sealing, the capillary was immediately placed in the resonator of the ESR spectrometer. ESR spectra were recorded at room temperature on a Bruker EMX 1273 spectrometer equipped with an ER $4119 H S$ high sensitivity resonator and a $12 \mathrm{~kW}$ power supply operating at $\mathrm{X}$ band frequencies. The modulation frequency of the spectrometer was $100 \mathrm{kHz}$. Instrumental conditions for the recorded spectra were as follows: magnetic field, $3450 \mathrm{G}$; scan range, 200 G; modulation amplitude, $1 \mathrm{G}$; receiver gain, $1 \times 10^{4}$; microwave frequency, $9.85 \mathrm{GHz}$; power, $50 \mathrm{~mW}$; time constant, $40.96 \mathrm{~ms}$; scan time, $20.97 \mathrm{~s}$; number of scans, 25 . Quantification of the characteristic DMPO-trapped hydroxyl radical signal (4 peaks splitting constant 14.9G, surface pattern 1:2:2:1) was performed by double integration peak surface measurements using the Bruker WIN-EPR spectrum manipulation program.

\subsubsection{Cellular reactive oxygen species}

Cellular generation of ROS in RAW 264.7 macrophages after exposure to $0.1-100 \mu \mathrm{g} / \mathrm{ml} \mathrm{Ag}$ NPs was measured using the $\mathrm{H}_{2}$ DCF-DA assay in 96 well plates as described earlier (Park 
et al. 2011). Briefly, cells were exposed to Ag NPs for 4h, washed with PBS and incubated with $10 \mu \mathrm{M} \mathrm{H}_{2}$ DCF-DA. After 45 minutes, cells were washed with PBS and fluorescence was measured in PBS at an excitation wavelength of $485 \mathrm{~nm}$ and an emission wavelength of 520 nm using a FLUOstar OPTIMA microplate reader (BMG LABTECH, Offenburg, Germany). At these wavelengths, Ag NPs alone in PBS were not fluorescent. Results were obtained from at least two independent experiments.

\subsubsection{Inflammation markers}

Release of inflammation markers (IL1 $\alpha$, IL1 $\beta$, IL6, IL10, MIP1 $\alpha$, MIP1 $\beta$, MIP2, G-CSF and TNF $\alpha$ ) were measured in supernatant of RAW 264.7 cells after $24 \mathrm{~h}$ of exposure to 1-100 $\mu \mathrm{g} / \mathrm{ml}$ Ag NPs using a Multiplex system (Bio-Plex Pro Mouse Cytokine kit, BioRad), allowing for simultaneous measurement of all 9 cytokines in one sample. Cells were seeded in 96well tissue culture plates at a density of $2 \times 10^{4}$ cells/well. After $24 \mathrm{~h}$, cell culture medium was removed and cells were exposed to $100 \mu \mathrm{l}$ of NP suspension $(0.3$ to $100 \mu \mathrm{g} / \mathrm{ml})$ in cell culture medium for $24 \mathrm{~h}$. Subsequently, the supernatant was collected and stored at $-80^{\circ} \mathrm{C}$ until cytokine analysis. Samples were collected from two independent experiments.

Cytokine analysis was performed according to the manufacturer's instructions, with minor modifications. Samples were analyzed both undiluted and diluted 100x with RAW 264.7 cell culture medium. Half of the recommended concentration of anti-cytokine conjugated beads were used, as this proved to be sufficient in past experiments (unpublished results). Concentrations of detection antibody and Streptavidin-PE were adjusted accordingly.

\subsubsection{Embryonic stem cell differentiation}

The potential for Ag NPs to inhibit embryonic stem cell differentiation was evaluated using the embryonic stem cell test according to methods described earlier (Park et al. 2009a). Briefly, D3 cell suspensions containing 5-100 $\mu \mathrm{g} / \mathrm{ml}$ Ag NPs were allowed to aggregate by preparing so called "hanging drops", which were cultured in a humidified atmosphere at $37^{\circ} \mathrm{C}$ in $5 \% \mathrm{CO}_{2}$. On day 3 , the cell aggregates (embryoid bodies) were transferred with $5 \mathrm{ml}$ fresh tissue culture medium containing Ag NPs to a bacterial petri dish and further cultured in suspension. On day 5 , the embryoid bodies were plated in 24-wells plates containing 1 embryoid body in $1 \mathrm{ml}$ fresh tissue culture medium with Ag NPs. For analysis of cell differentiation, the number of wells containing embryoid bodies with spontaneously contracting myocardial foci was determined on day 10 by phase contrast microscopy. At least two independent experiments were performed for each Ag NP.

\subsubsection{Genotoxicity}

The mutagenic potential of Ag NPs was evaluated in embryonic fibroblasts (MEF-LacZ) according to methods described earlier (Park et al. 2011). Briefly, MEF-LacZ cells were exposed to $0.1-100 \mu \mathrm{g} / \mathrm{ml}$ of Ag NPs for $16 \mathrm{~h}$ in $10 \mathrm{~cm}$ petri dishes and collected with a cell scraper. Total genomic DNA containing (parts of) the lacZ gene was isolated from the 
cells using phenol extraction, followed by digestion with the restriction enzyme HindIII. The lacZ containing plasmids were rescued from the digest and transfected into an electrocompetent $E$. coli strain $C(\Delta / a c Z / g a l E-)$. Small fractions of the bacterial samples were incubated on non-selective X-galactosidase plates to determine the plasmid rescue efficiency. The remainder was incubated on selective P-glycosidase plates to select for mutants. The lacZ mutant frequency was calculated by dividing the number of mutants by the total number of rescued colonies $\times$ dilution factor. Results were obtained from at least two independent experiments.

\subsubsection{Data analysis}

Experimental data from all duplicate experiments and all particle sizes were combined in one dataset, which was analyzed using the dose-response modeling software PROAST (RIVM 2009; Slob 2002) according to methods described earlier (Park et al. 2009a). Briefly, the PROAST software selects the optimal data fitting model from an exponential family of models using the likelihood-ratio criterion (EFSA 2009; RIVM 2009; Slob 2002):

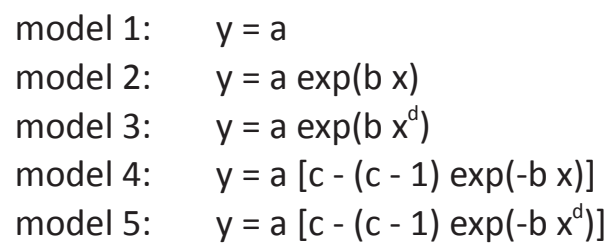

where the level of measured parameter $y$ is a function of nanoparticle concentration $x$.

The experiment or plate number was defined as a covariate for parameter $a$, reflecting the level of the measured parameter at concentration zero, thereby taking into account the differences between experiments and/or plates. For the comparison of particles, the particle identification $(20,80,113)$ was defined as a covariate for parameter $b$, which reflects the potency of the administered agent (Slob 2002). The potential differences between particle sizes was further quantified by the 'Benchmark' concentration of Ag NPs, defined as the (nominal) concentration resulting in a $20 \%$ response compared to the solvent control group.

Data from the LacZ gene mutation test were also analyzed by means of the nonparametric Kruskall-Wallis test.

\subsection{RESULTS}

\subsubsection{Metabolic activity (WST-1) in fibroblasts and macrophages}

In both L929 fibroblasts and RAW 264.7 macrophages, metabolic activity was decreased concentration-dependently by Ag NPs as well as by ionic Ag, as measured by reduction of 
WST-1 (Figure 6.2, Table 6.2). For ionic silver, the decrease in metabolic activity was similar between the cell types ( $\mathrm{EC}_{20}$ values of 7.1 and $6.7 \mu \mathrm{g} / \mathrm{ml}$ for $\mathrm{L929}$ and RAW 264.7 , respectively) and their confidence intervals overlapped, implying there were no statistically significant differences between the two cell types. In contrast, for Ag NPs, the metabolic activity was significantly more affected in L929 fibroblasts compared to RAW 264.7 macrophages.

$$
\mathrm{EC}_{20}(\mu \mathrm{g} / \mathrm{ml})
$$

RAW $264.7 \quad$ L929

WST

$\begin{array}{lllll}20 \mathrm{~nm} & 7 & (6-8) & 2.8 & (2.7-2.9) \\ 80 \mathrm{~nm} & 38 & (33-44) & 17 & (15-18) \\ 113 \mathrm{~nm} & >100 & & 12 & (11-13) \\ \mathrm{AgNO}_{3} & 7 & (5-7) & 7.1 & (6.8-7.4)\end{array}$

Extracellular LDH

$\begin{array}{lllll}20 \mathrm{~nm} & 66 & (45-112) & 0.2 & (0.1-0.3) \\ 80 \mathrm{~nm} & >100 & & 5.2 & (2.3-8.0) \\ 113 \mathrm{~nm} & >100 & & 2.4 & (1.6-3.1) \\ \mathrm{AgNO}_{3} & 5.1 & (3.3-7.8) & 3.7 & (2.6-7.2)\end{array}$

Table 6.2 $\mathrm{EC}_{20}$ values and confidence intervals of silver nanoparticles for metabolic activity and cell membrane integrity of RAW 264.7 macrophages and L929 fibroblasts.

In both cell types, the smallest Ag NPs of $20 \mathrm{~nm}$ were most potent in decreasing metabolic activity, with $\mathrm{EC}_{20}$ values of 2.7 and $7 \mu \mathrm{g} / \mathrm{ml}$ for $\mathrm{L929}$ and RAW 264.7, respectively. For RAW 264.7 macrophages, this $\mathrm{EC}_{20}$ value was similar to that of ionic Ag. In contrast, in L929 fibroblasts, metabolic activity was affected more by $20 \mathrm{~nm} \mathrm{Ag} \mathrm{NPs}\left(\mathrm{EC}_{20} 2.8 \mu \mathrm{g} / \mathrm{ml}\right)$ than by ionic $\mathrm{Ag}\left(\mathrm{EC}_{20} 7.1 \mu \mathrm{g} / \mathrm{ml}\right)$. In both cell types, the larger 80 and $113 \mathrm{~nm}$ NPs were less effective in reducing metabolic activity compared to ionic Ag.

\subsubsection{Cell membrane integrity (LDH) in fibroblasts and macrophages}

As measured by extracellular LDH activity, cell membrane integrity in L929 fibroblasts was compromised by all three Ag NPs, with $20 \mathrm{~nm} \mathrm{Ag} \mathrm{NPs} \mathrm{being} \mathrm{more} \mathrm{potent} \mathrm{than} 80$ and $113 \mathrm{~nm}$ Ag NPs (Figure 6.3, Table 6.2). In contrast, cell membrane integrity of RAW 264.7 macrophages was affected only marginally by $20 \mathrm{~nm} \mathrm{Ag} \mathrm{NPs} \mathrm{and} \mathrm{not} \mathrm{by} \mathrm{the} \mathrm{larger} \mathrm{NPs.}$ While there were large differences in effects between cell types for Ag NPs, Ag in ionic form affected cell membrane integrity of both RAW 264.7 and L929 to the same extent. Ag NPs of $20 \mathrm{~nm}$ were more potent in reducing cell membrane integrity of $L 929$ fibroblasts than ionic Ag. In RAW 264.7 macrophages, ionic Ag was much more potent in reducing cell membrane integrity than any of the NPs. 

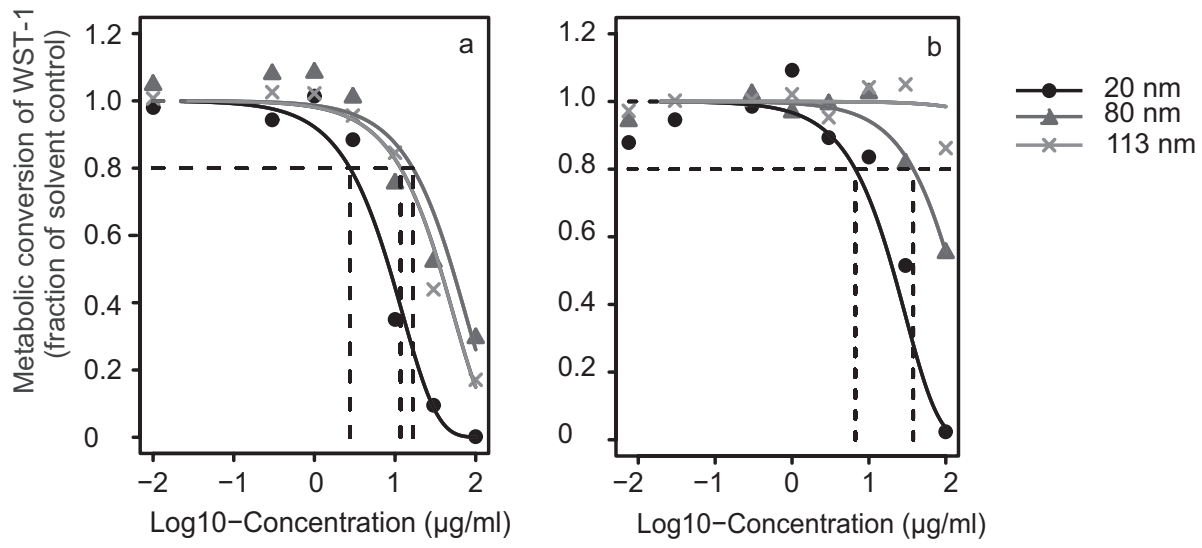

Figure 6.2 Metabolic conversion of WST-1 in L929 fibroblasts (A) and RAW 264.7 macrophages (B) as a function of concentration of silver nanoparticles. Dashed lines represent $\mathrm{EC}_{20}$ values.

\section{Peak surface of DMPO-OH}

(Arbitrary Units)

\begin{tabular}{ll}
\hline $20 \mathrm{~nm}$ & 109 \\
$80 \mathrm{~nm}$ & 356 \\
$113 \mathrm{~nm}$ & 360 \\
\hline
\end{tabular}

Table 6.3 Acellular induction of reactive oxygen species by silver nanoparticles using Electron Spin Resonance (ESR) spectroscopy in combination with the spin trapping technique.

\subsubsection{Acellular generation of reactive oxygen species}

The acellular generation of ROS was investigated by means of electron spin resonance. The $\mathrm{H}_{2} \mathrm{O}_{2}$-induced formation of hydroxyl radicals by 80 and $113 \mathrm{~nm}$ Ag NPs was very similar, while that of the $20 \mathrm{~nm}$ NPs was lower (Table 6.3).

\subsubsection{Cellular generation of reactive oxygen species in macrophages}

As measured by the $\mathrm{H}_{2}$ DCF-DA assay, exposure of RAW 264.7 macrophages to $20 \mathrm{~nm}$ Ag NPs resulted in an increased generation of ROS, while the larger NPs had only very marginal effects (Figure 6.4). The $\mathrm{EC}_{20}$ value (1.2 fold increase) and confidence interval for $20 \mathrm{~nm}$ Ag NPs was $25(22-28) \mu \mathrm{g} / \mathrm{ml}$. 

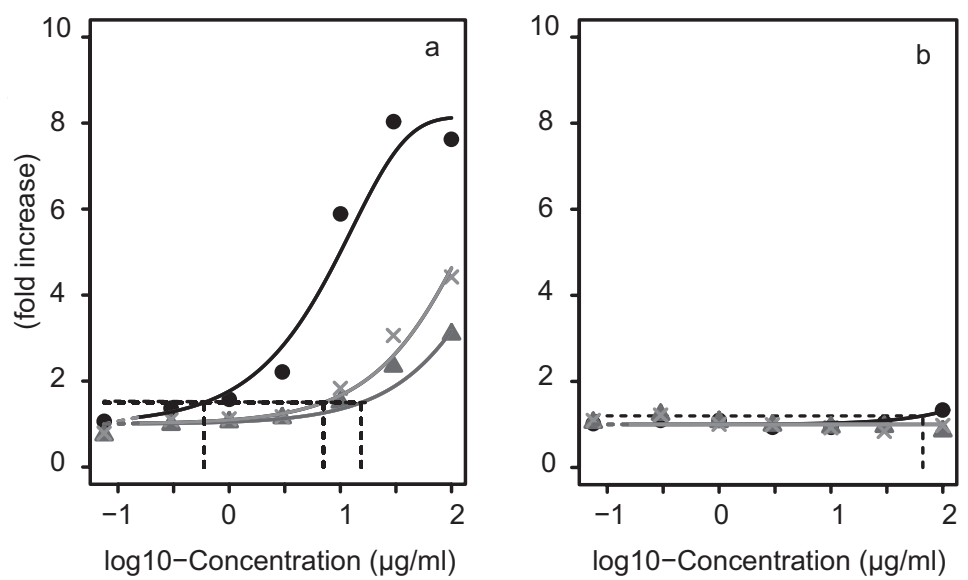

Figure 6.3 Extracellular LDH activity in L929 fibroblasts (A) and RAW 264.7 macrophages (B) as a function of concentration of silver nanoparticles. Dashed lines represent $\mathrm{EC}_{20}$ values.

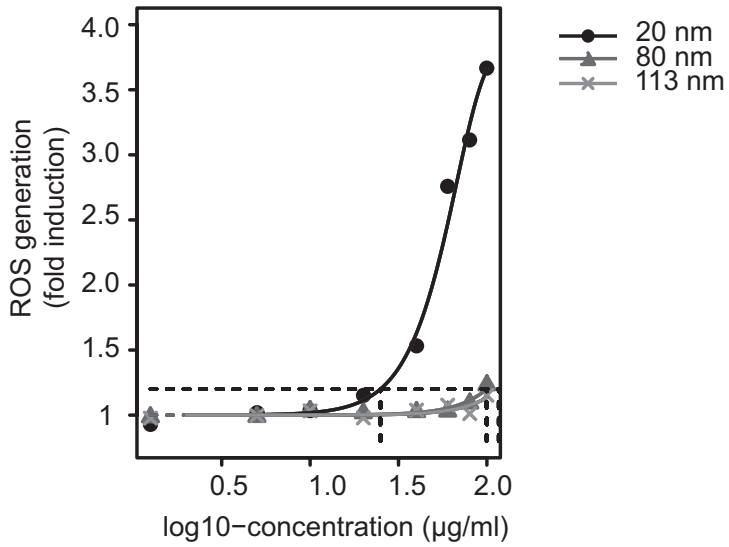

Figure 6.4 Generation of ROS in RAW 264.7 as a function of concentration of silver nanoparticles, as measured by the $\mathrm{H}_{2}$ DCF-DA assay. Dashed lines represent $\mathrm{EC}_{20}$ values.

\subsubsection{Release of inflammatory markers from macrophages}

Exposure of RAW 264.7 macrophages to all NPs tested resulted in the release of a variety of inflammatory markers (Table 6.4). The extent of the release, presented as fold increase compared to non treated control cells (spontaneous production) varied widely between markers, ranging from a less than 5 fold increase for IL1 $\beta$ and IL10, to a more than 500 fold induction for G-CSF compared to non-treated control cells. All markers except IL10 were induced most by $20 \mathrm{~nm}$ Ag NPs. 


\begin{tabular}{llll} 
& Ag $\mathbf{2 0} \mathbf{n m}$ & Ag $80 \mathbf{n m}$ & Ag $\mathbf{1 1 3} \mathbf{~ n m}$ \\
\hline IL1 $\alpha$ & 6 & 1 & 1 \\
IL1 $\beta$ & 2 & 2 & 2 \\
IL6 & 16 & 2 & 4 \\
IL10 & 2 & 3 & 4 \\
TNF $\alpha$ & 191 & 78 & 57 \\
G-CSF & 2625 & 597 & 533 \\
MIP1 $\alpha$ & 27 & 16 & 22 \\
MIP1 $\beta$ & 17 & 7 & 8 \\
MIP2 & 202 & 37 & 34 \\
\hline
\end{tabular}

Table 6.4 Maximum fold induction of inflammatory markers from RAW 264.7 macrophages after exposure to silver nanoparticles for 24 hours.

\subsubsection{Embryonic stem cell differentiation}

Differentiation of murine embryonic stem cells into contracting cardiomyocytes was dosedependently inhibited by all Ag NPs (Figure 6.5). The $20 \mathrm{~nm} \mathrm{Ag} \mathrm{NPs} \mathrm{were} \mathrm{most} \mathrm{potent}$ of the NPs, but not as potent as ionic Ag. The effects on stem cell differentiation were observed at higher Ag concentrations than those associated with a decrease in metabolic conversion of WST-1 in the stem cells after exposure for 10 days (Table 6.5).

$\mathrm{EC}_{20}(\mu \mathrm{g} / \mathrm{ml})$

\begin{tabular}{llll}
\hline & \multicolumn{2}{l}{ Differentiation } & Metabolic conversion \\
$20 \mathrm{~nm}$ & 12 & $(10-13)$ & $3(2-4)$ \\
$80 \mathrm{~nm}$ & 31 & $(26-37)$ & $33(19-48)$ \\
$113 \mathrm{~nm}$ & 29 & $(26-32)$ & $43(14-70)$ \\
$\mathrm{AgNO}_{3}$ & 6 & $(5-7)$ & $0.3(0.3-0.4)$ \\
\hline
\end{tabular}

Table 6.5 $\mathrm{EC}_{20}$ values and confidence intervals of silver nanoparticles and silver ions associated with a $20 \%$ inhibition of stem cell differentiation and a $20 \%$ decrease in metabolic activity in D3 mouse embryonic stem cells.

\subsubsection{Genotoxicity}

Ag NPs of $20 \mathrm{~nm}$ did not induce an increase in gene mutation frequencies up to $3 \mu \mathrm{g} / \mathrm{ml}$, above which concentrations were too cytotoxic to collect sufficient DNA for the plasmid rescue (Figure 6.6). An increase in gene mutation frequencies was observed in cells treated with $113 \mathrm{~nm}$ compared to controls, but the increase was neither dose-related nor statistically significant. A dose related increase in gene mutation frequencies was observed in cells treated with $80 \mathrm{~nm}$ Ag NPs, but also did not reach statistical significance. 

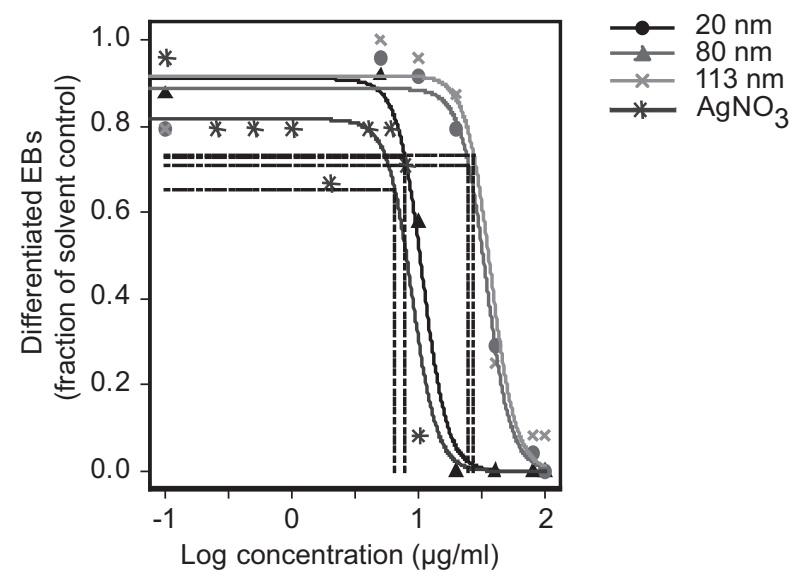

Figure 6.5 Differentiation of embryoid bodies (EBs) into spontaneously contracting cardiomyocytes as a function of the silver (nanoparticle or ion) concentration. Data was fitted with a log-logistic dose-response model: $y=$ $a+(1-a) /(1+\exp (c \cdot \ln (b / x)))$. Dashed lines represent $\mathrm{EC}_{20}$ values.

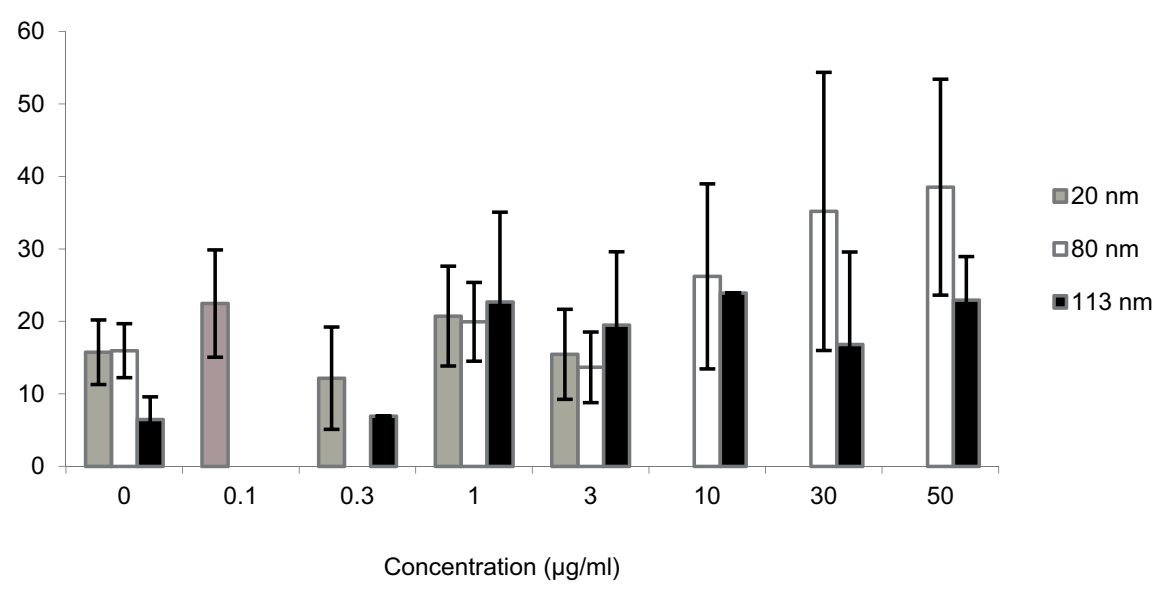

Figure 6.6 Mutant frequencies in MEF-LacZ cells exposed to silver nanoparticles.

The concentration of $80 \mathrm{~nm}$ Ag NPs inducing a $20 \%$ decrease in metabolic activity in MEF-LacZ cells was $1.1 \mu \mathrm{g} / \mathrm{ml}$ (confidence interval 0.9-1.4 $\mu \mathrm{g} / \mathrm{ml}$ ), indicating that the concentrations inducing an increase in gene mutation frequencies were cytotoxic (Figure 6.7).

\subsection{DISCUSSION}

We compared the effects of Ag NPs of different sizes in assays for cellular metabolic activity, membrane integrity, generation of ROS, markers of inflammation, developmental toxicity and genotoxicity. Of all toxicity endpoints studied, the most pronounced effect was observed in 1929 fibroblasts, where Ag NPs of all tested sizes compromised cell membrane integrity and, at higher concentrations, metabolic activity. The reverse was 
observed in RAW 264.7 macrophages, where the effect on metabolic activity occurred at lower concentrations than those on cell membrane activity. Effects in macrophages were seen at higher concentrations compared to fibroblasts, and it can be speculated that the membranes of macrophages are better equipped to handle the uptake and neutralization $\mathrm{Ag}$ NPs due to their function as particle and micro-organism scavengers.

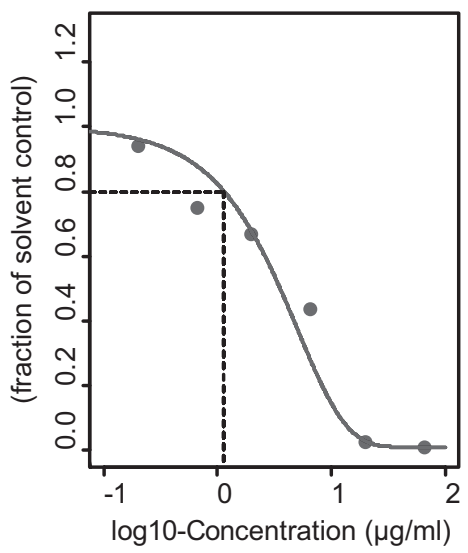

Figure 6.7 Metabolic conversion of WST-1 in MEF-LacZ cells as a function of concentration of $80 \mathrm{~nm}$ silver nanoparticles. Dashed lines represent $\mathrm{EC}_{20}$ values.

A number of studies suggested that cytotoxic effects of Ag NPs in macrophages were mediated by the generation of oxidative stress (Carlson et al. 2008; Foldbjerg et al. 2009; Park et al. 2010). Oxidative stress is induced when the generation of ROS exceeds the cell's antioxidant capacity. Apart from the damaging effects to cellular proteins, lipids and DNA, an increasing level of ROS triggers the cell to respond by activating pro-inflammatory signalling cascades, and ultimately induces programmed cell death ( $\mathrm{Nel}$ et al. 2006). Interestingly, the acellular potential of the $20 \mathrm{~nm}$ NPs to generate ROS as measured by electron spin resonance techniques was lower than that of the larger NPs, while its cellular ROS generation was higher. This suggests that the generation of ROS in macrophages was an indirect effect of the interaction of the NPs with cellular components, similar to what was shown previously with polystyrene NPs (Xia et al. 2006). The generation of ROS in macrophages occurred only at concentrations above those decreasing metabolic activity of macrophages, and it is possible that the generation of ROS was a secondary effect rather than causing the onset of cytotoxicity. To elucidate the role of ROS, future studies should determine the effects of NPs on cytotoxicity, for example in the presence of radical scavengers.

Whether or not the generation of ROS was involved in the effects on metabolic activity, membrane integrity or cytokine production, it did not lead to significant DNA damage, judged by the absence of statistically significant effects on gene mutations in MEF-LacZ cells. A dose-response related increase in gene mutations was observed in cells exposed 
to $80 \mathrm{~nm} \mathrm{Ag} \mathrm{NPs,} \mathrm{but} \mathrm{this} \mathrm{was} \mathrm{not} \mathrm{statistically} \mathrm{significant.} \mathrm{In} \mathrm{addition,} \mathrm{the} \mathrm{concentrations}$ at which an increase in gene mutations was observed were starting to become cytotoxic, i.e. the observed mutations may have been the result of DNA undergoing fragmentation in the process of apoptosis. Along the same lines, the effects of Ag NPs on embryonic stem cell differentiation occurred only at concentrations similar to or above those decreasing metabolic activity, indicating the effects on stem cell differentiation were also a direct result of cytotoxicity, rather than a specific effect of the NPs on differentiation of the embryonic stem cells.

Exposure to Ag NPs induced the release of a number of pro-inflammatory markers, most markedly TNF $\alpha$, MIPs and G-CSF, confirming previous findings of studies with Ag NPs in macrophages (Carlson et al. 2008; Nishanth et al. 2011; Park et al. 2010). Macrophages are the major producers of TNF $\alpha$, which has an important role in regulating cytokine production (Parameswaran and Patial 2010). The macrophage inflammatory proteins MIP1 $\alpha$, MIP1 $\beta$ and MIP2 are known for their chemotactic properties for neutrophils in response to injury, infection and cancer (Driscoll 1994). Similarly, one of G-CSF's major functions is to influence the maturation and release of neutrophils from the bone marrow, and enhance their chemotactic and phagocytic function (Steward 1993). The production of cytokines by macrophages was originally described in relation to their response to a range of micro-organisms, which ultimately leads to the destruction of these organisms. However, various studies have now shown that macrophages also produce cytokines in response to other stressors, including (nano)particles (reviewed by Chang 2010). While the production of cytokines in itself should not be considered an adverse effect, it can be anticipated that persistent (over)production and signaling of cytokines in response to NPs may lead to inflammatory diseases.

Based on mass concentrations, the $20 \mathrm{~nm} \mathrm{Ag} \mathrm{NPs} \mathrm{induced} \mathrm{the} \mathrm{highest} \mathrm{response} \mathrm{in} \mathrm{all}$ assays included in this study compared to the larger NPs, with differences between EC $_{20}$ values of one order of magnitude in some assays. This indicates that deriving exposure limits for Ag NPs based on mass concentrations does not appear to be appropriate. On the other hand, if exposure limits are going to be derived based on another metric like surface area or number of particles, it needs to be taken into consideration that Ag NPs of different sizes have also been shown to follow different kinetics and have a different distribution pattern (Lankveld et al. 2010).

The cellular uptake of smaller NPs may have been easier compared to that of larger particles, which needs to be confirmed by quantitative measurements. Others have suggested that the higher cytotoxicity of smaller particles compared to larger ones was related to the amount of ROS generated at the relatively larger surface area of small NPS (Carlson et al. 2008; Liu et al. 2010). However, this was not supported in our study, where the in vitro generation of ROS in a cell free system was not predictive for the cellular induction of ROS. Alternatively, smaller NPs may display or release more silver ions from its surface than larger NPs. Park et al (2010) suggested that Ag NPs dissolve into cytotoxic 
Ag ions upon phagocytosis and transportation of the NPs to lysosomes, mimicking a Trojan Horse. On the other hand, genotoxicity studies reported that effects on gene mutations and micronucleus formation were at least in part independent of Ag ions (Demir et al. 2010; Kawata et al. 2009). On the whole, it remains unclear to what extent Ag ions contribute to the effects observed with Ag NPs. For the current study, we have only investigated uncoated Ag NPs of different sizes with similar surface charges. It needs to be noted that surface charge and chemistry may play an additional and even larger role in determining the surface release of $\mathrm{Ag}$ ions, the distribution of and biological response to Ag NPs than particle size.

For risk assessors, it is of paramount interest to understand the extent of the effects of Ag NPs compared to those of Ag ions. In our study, L929 fibroblasts were more sensitive to the effects of $20 \mathrm{~nm}$ NPs, which is similar to what was reported for human liver cells (Piao et al. 2011). Peritoneal macrophages were approximately equally sensitive to the effects of $\mathrm{Ag}$ ions and of $20 \mathrm{~nm} \mathrm{Ag} \mathrm{NPs,} \mathrm{while} \mathrm{the} \mathrm{larger} \mathrm{particles} \mathrm{were} \mathrm{less} \mathrm{toxic} \mathrm{than} \mathrm{Ag} \mathrm{ions.}$ This is similar to what was reported for alveolar macrophages, where Ag ions affected cell metabolic activity to the same extent as 15 and $30 \mathrm{~nm}$ particles, and more than $55 \mathrm{~nm}$ particles (Carlson et al. 2008). The effects of Ag NPs compared to Ag ions on four human cell lines was also dependent on the size of the NPs, with $5 \mathrm{~nm}$ particles being more toxic, but 20 and $50 \mathrm{~nm}$ being less toxic than Ag ions (Liu et al. 2010). It seems therefore, that the effects of Ag NPs in comparison to those of $\mathrm{Ag}$ ions depend on the cell type considered, but also on NP size. However, for both Ag ions and Ag NPs, the concentrations inducing cytotoxicity were much higher than those reported to have antimicrobial activity. This indicates that there may be a margin of safety between exposure for antimicrobial application of Ag NPs and adverse effects observed in human cells. Clearly, before one can draw such conclusions, more information is needed on the (long-term) exposure to and accumulation of Ag NPs in the body, in addition to the assessment of other toxicity endpoints.

\subsection{CONCLUSIONS}

Our collective results suggest that the most pronounced effect of Ag NPs is inflicting damage towards a range of different cell types, potentially resulting in a myriad of secondary effects, such as generation of ROS, DNA damage and inhibiting stem cell differentiation. Despite the likelihood that macrophages will be amongst the highest exposed cell types, our studies showed that they may not be the most sensitive to the effects of $\mathrm{Ag}$ NPs, indicating that other cell types may need to be included in the evaluation of the biocompatibility of ENMs. We observed large differences in toxic concentrations between NPs of different sizes, indicating that deriving exposure limits for Ag NPs based on mass concentrations does not appear to be appropriate. Whether the risk of being exposed to $\mathrm{Ag}$ NPs is higher compared to Ag ions is a complex question that depends on a number 
of factors, including bioavailability, distribution pattern, exposed cell type, Ag NP size and likely surface chemistry. Deriving safe exposure limits for Ag NPs should therefore be handled on a case-by-case approach.

\section{ACKNOWLEDGMENTS}

The authors thank Prof. Wout Slob for his assistance with the data analysis.

\section{DECLARATION OF INTEREST}

The authors declare that there are no conflicts of interest. 


\section{REFERENCES}

Ahamed M, Karns M, Goodson M, Rowe J, Hussain SM, Schlager JJ, Hong Y. 2008. DNA damage response to different surface chemistry of silver nanoparticles in mammalian cells. Toxicol Appl Pharmacol 233(3):404-10.

Asharani PV, Lianwu Y, Gong Z, Valiyaveettil S. 2011. Comparison of the toxicity of silver, gold and platinum nanoparticles in developing zebrafish embryos. Nanotoxicology 5(1):4354.

AshaRani PV, Low Kah Mun G, Hande MP, Valiyaveettil S. 2009. Cytotoxicity and genotoxicity of silver nanoparticles in human cells. ACS Nano 3(2):279-90.

Bar-Ilan O, Albrecht RM, Fako VE, Furgeson DY. 2009. Toxicity assessments of multisized gold and silver nanoparticles in zebrafish embryos. Small 5(16):1897-910.

Bhol KC, Schechter PJ. 2007. Effects of nanocrystalline silver (NPI 32101) in a rat model of ulcerative colitis. Dig Dis Sci 52(10):2732-42.

Braydich-Stolle L, Hussain S, Schlager JJ, Hofmann MC. 2005. In vitro cytotoxicity of nanoparticles in mammalian germline stem cells. Toxicol Sci 88(2):412-9.

Carlson C, Hussain SM, Schrand AM, Braydich-Stolle LK, Hess KL, Jones RL, Schlager JJ. 2008. Unique cellular interaction of silver nanoparticles: size-dependent generation of reactive oxygen species. J Phys Chem B 112(43):13608-19.

Chang C. 2010. The immune effects of naturally occurring and synthetic nanoparticles. J Autoimmun 34(3):J234-46.

Christensen FM, Johnston HJ, Stone V, Aitken RJ, Hankin S, Peters S, Aschberger K. 2010. Nanosilver - feasibility and challenges for human health risk assessment based on open literature. Nanotoxicology 4(3):284-95.

Demir E, Vales G, Kaya B, Creus A, Marcos R. 2010. Genotoxic analysis of silver nanoparticles in Drosophila. Nanotoxicology.

Driscoll KE. 1994. Macrophage inflammatory proteins: biology and role in pulmonary inflammation. Exp Lung Res 20(6):473-90.

EFSA. 2009. Guidance of the Scientific Committee on a request from EFSA on the use of the benchmark dose approach in risk assessment. The EFSA journal 1150:1-72.

Foldbjerg R, Dang DA, Autrup H. 2010. Cytotoxicity and genotoxicity of silver nanoparticles in the human lung cancer cell line, A549. Arch Toxicol.

Foldbjerg R, Olesen P, Hougaard M, Dang DA, Hoffmann HJ, Autrup H. 2009. PVP-coated silver nanoparticles and silver ions induce reactive oxygen species, apoptosis and necrosis in THP-1 monocytes. Toxicol Lett 190(2):156-62.

Hackenberg S, Scherzed A, Kessler M, Hummel S, Technau A, Froelich K, Ginzkey C, Koehler C, Hagen R, Kleinsasser N. 2011. Silver nanoparticles: evaluation of DNA damage, toxicity and functional impairment in human mesenchymal stem cells. Toxicol Lett 201(1):2733.

Kawata K, Osawa M, Okabe S. 2009. In vitro toxicity of silver nanoparticles at noncytotoxic doses to HepG2 human hepatoma cells. Environ Sci Technol 43(15):6046-51.

Lankveld DP, Oomen AG, Krystek P, Neigh A, Troost-de Jong A, Noorlander CW, Van Eijkeren JC, Geertsma RE, De Jong WH. 2010. The kinetics of the tissue distribution of silver nanoparticles of different sizes. Biomaterials 31(32):8350-8361. 
Lee KJ, Nallathamby PD, Browning LM, Osgood CJ, Xu XH. 2007. In vivo imaging of transport and biocompatibility of single silver nanoparticles in early development of zebrafish embryos. ACS Nano 1(2):133-43.

Li PW, Kuo TH, Chang JH, Yeh JM, Chan WH. 2010. Induction of cytotoxicity and apoptosis in mouse blastocysts by silver nanoparticles. Toxicol Lett 197(2):82-7.

Liu W, Wu Y, Wang C, Li HC, Wang T, Liao CY, Cui L, Zhou QF, Yan B, Jiang GB. 2010. Impact of silver nanoparticles on human cells: effect of particle size. Nanotoxicology 4(3):319-30.

Mahabir AG, Zwart E, Schaap M, van Benthem J, de Vries A, Hernandez LG, Hendriksen CF, van Steeg H. 2009. lacZ mouse embryonic fibroblasts detect both clastogens and mutagens. Mutat Res 666(1-2):50-56.

Nel A, Xia T, Madler L, Li N. 2006. Toxic potential of materials at the nanolevel. Science 311(5761):622-7. Nishanth RP, Jyotsna RG, Schlager JJ, Hussain SM, Reddanna P. 2011. Inflammatory responses of RAW 264.7 macrophages upon exposure to nanoparticles: Role of ROS-NFkappaB signaling pathway. Nanotoxicology.

Parameswaran N, Patial S. 2010. Tumor necrosis factor-alpha signaling in macrophages. Crit Rev Eukaryot Gene Expr 20(2):87-103.

Park EJ, Yi J, Kim Y, Choi K, Park K. 2010. Silver nanoparticles induce cytotoxicity by a Trojan-horse type mechanism. Toxicol In Vitro 24(3):872-8.

Park MVDZ, Annema W, Salvati A, Lesniak A, Elsaesser A, Barnes C, McKerr G, Howard CV, Lynch I, Dawson KA and others. 2009a. In vitro developmental toxicity test detects inhibition of stem cell differentiation by silica nanoparticles. Toxicol Appl Pharmacol 240:108-116.

Park MVDZ, Lankveld DPK, van Loveren H, de Jong W. 2009b. The status of in vitro toxicity studies in risk assessment of nanomaterials Nanomedicine 4(6):669-685.

Park MVDZ, Verharen HW, Zwart E, Hernandez LG, van Benthem J, Elsaesser A, Barnes C, McKerr G, Howard CV, Salvati A and others. 2011. Genotoxicity evaluation of amorphous silica nanoparticles of different sizes using the micronucleus and the plasmid lacZ gene mutation assay. Nanotoxicology 5:168-81.

Piao MJ, Kang KA, Lee IK, Kim HS, Kim S, Choi JY, Choi J, Hyun JW. 2011. Silver nanoparticles induce oxidative cell damage in human liver cells through inhibition of reduced glutathione and induction of mitochondria-involved apoptosis. Toxicol Lett 201(1):92-100.

RIVM. 2009. PROAST: Software for dose-response modeling and benchmark dose analysis. Available from: www.proast.nl.

Schrand AM, Rahman MF, Hussain SM, Schlager JJ, Smith DA, Syed AF. 2010. Metal-based nanoparticles and their toxicity assessment. Wiley Interdiscip Rev Nanomed Nanobiotechnol 2(5):544-68.

Shavandi Z, Ghazanfari T, Moghaddam KN. 2011. In vitro toxicity of silver nanoparticles on murine peritoneal macrophages. Immunopharmacol Immunotoxicol 33(1):135-40.

Shin SH, Ye MK, Kim HS, Kang HS. 2007. The effects of nano-silver on the proliferation and cytokine expression by peripheral blood mononuclear cells. Int Immunopharmacol 7(13):1813-8.

Slob W. 2002. Dose-response modeling of continuous endpoints. Toxicol Sci 66(2):298-312.

Soto K, Garza KM, Murr LE. 2007. Cytotoxic effects of aggregated nanomaterials. Acta Biomater 3(3):351-8.

Steward WP. 1993. Granulocyte and granulocyte-macrophage colony-stimulating factors. Lancet 342(8864):153-7. 
Stone V, Johnston H, Schins RP. 2009. Development of in vitro systems for nanotoxicology: methodological considerations. Crit Rev Toxicol 39(7):613-26.

Tian J, Wong KK, Ho CM, Lok CN, Yu WY, Che CM, Chiu JF, Tam PK. 2007. Topical delivery of silver nanoparticles promotes wound healing. ChemMedChem 2(1):129-36.

Trickler WJ, Lantz SM, Murdock RC, Schrand AM, Robinson BL, Newport GD, Schlager JJ, Oldenburg SJ, Paule MG, Slikker W, Jr. and others. 2010. Silver nanoparticle induced blood-brain barrier inflammation and increased permeability in primary rat brain microvessel endothelial cells. Toxicol Sci 118(1):160-70.

Van Maanen JM, Borm PJ, Knaapen A, van Herwijnen M, Schilderman PA, Smith KR, Aust AE, Tomatis $M$, Fubini B. 1999. In vitro effects of coal fly ashes: hydroxyl radical generation, iron release, and DNA damage and toxicity in rat lung epithelial cells. Inhal Toxicol 11(12):1123-41.

Wijnhoven SWP, Peijnenburg WJGM, Herberts CA, Hagens WI, Oomen AG, Heugens EHW, Roszek B, Bisschops J, Gosens I, Van De Meent D and others. 2009. Nano-silver - a review of available data and knowledge gaps in human and environmental risk assessment. Nanotoxicology 3(2):109138.

Wong KK, Cheung SO, Huang L, Niu J, Tao C, Ho CM, Che CM, Tam PK. 2009. Further evidence of the anti-inflammatory effects of silver nanoparticles. ChemMedChem 4(7):1129-35.

Xia T, Kovochich M, Brant J, Hotze M, Sempf J, Oberley T, Sioutas C, Yeh JI, Wiesner MR, Nel AE. 2006. Comparison of the abilities of ambient and manufactured nanoparticles to induce cellular toxicity according to an oxidative stress paradigm. Nano Lett 6(8):1794-807. 



\section{CHAPTER 7}

\section{A PRACTICAL WAY FORWARD TO DETERMINE APPROPRIATE DOSE METRICS FOR ENGINEERED NANOMATERIALS}

Margriet V.D.Z. Park ${ }^{1}$ Wim H. de Jong ${ }^{1}$

Agnes G. Oomen ${ }^{2}$

Christiaan J. Delmaar ${ }^{2}$

${ }^{1}$ National Institute for Public Health and the Environment, Laboratory for Health Protection

Research, P.O. Box 1, 3720 BA, Bilthoven, the Netherlands

${ }^{2}$ National Institute for Public Health and the Environment, Department for Substances and Integrated Risk Assessment, P.O. Box 1, 3720 BA, Bilthoven, the Netherlands 


\section{ABSTRACT}

Exposure limits for soluble substances are traditionally based on mass concentrations, since mass is directly proportional to the number of molecules. In contrast, a specific mass of a variety of nanomaterials consisting of the same chemical substance but with different properties such as particle size may have completely different toxicity profiles. Information on the administered mass of nanomaterials alone may therefore not be a sufficient description of the dose that determines differences between biological responses. Other reduced dose metrics such as particle numbers or surface area may be more appropriate, but it is yet to be demonstrated that the use of such a simple dose metric is justifiable.

Here we present a mathematical based graphical method to determine whether a reduced dose metric for nanomaterials exists. To illustrate the method, it was applied to results from in vitro experiments with $\mathrm{Ag}$ and $\mathrm{SiO}_{2}$ nanoparticles. We show that a reduced dose metric for these nanoparticles exists, although there were differences in appropriate dose metrics between $\mathrm{Ag}$ and $\mathrm{SiO}_{2}$ nanoparticles and between toxicity endpoints.

\subsection{INTRODUCTION}

Traditionally, risk assessors derive safe exposure limits for chemical substances based on information on the toxic potential of the substances obtained from standardized safety studies in which increasing doses of the substance are administered to groups of animals. This procedure requires an adequate description of the dose, or dose metric, which includes all characteristics that are necessary to explain differences between responses in experiments. A minimal criterion for an adequate dose metric is that if experiments show a different toxicological or kinetic response, the doses in the experiments, specified according to the dose metric, should be different also. For most substances, total mass of the administered substance is used as a unique measure of the dose, as in most conditions, this is proportional to the number of molecules. Consequently, safe exposure limits are generally based on mass concentrations, i.e., are given as the maximum tolerable daily intake of a specific mass of chemical substance per kg body weight or cubic meter of air, with the exception of asbestos, for which exposure limits are given in number of fibres per cubic meter.

With nanotechnology facilitating the creation of complex spheres, cylinders, pyramids and other forms of different sizes, a whole new array of materials has made its appearance. The different characteristics of these NPs (e.g. size, shape and surface chemistry) all may determine their toxic potential (Clift et al. 2011; Duffin et al. 2007; Park et al. 2011b; Poland et al. 2011; Schaeublin et al. 2011). It follows that for ENMs, information on the administered mass of the chemical substance alone is not a sufficient description of the dose that determines a particular response in a biological system. This poses a problem for risk assessors, who are faced with the question of what dose metric to use when setting exposure limits for ENMs.

One solution would be to derive separate exposure limits for all different ENMs, i.e. one exposure limit for Ag NPs of $20 \mathrm{~nm}$ and a surface potential of $-50 \mathrm{mV}$, another limit for Ag 
NPs with the same surface potential, but with a particle size of $25 \mathrm{~nm}$, and yet another one for Ag NPs with particle size of $20 \mathrm{~nm}$, but with a surface potential of -35 mV. However, apart from being highly impractical, this approach also poses another set of problems. Virtually all ENMs are a heterogeneous mix of NPs with a distribution in characteristics rather than consisting of NPs all with exactly the same size and surface properties. This also implies that in contrast to mass and molecules for chemical substances, there is not necessarily an unequivocal relation between the mass and the number of NPs. In its most complete form, the dose of an ENM can be described by a (distribution) function $\mathrm{P}_{\mathrm{N}}$ that specifies the number of particles in the ENM with specific characteristics. For example $P_{N}(d, \zeta, \alpha, \ldots)$ may give the number of particles $\mathrm{N}$ with a diameter $d$, surface potential $\zeta$ and shape $\alpha$.

For risk assessment purposes and for upholding chemical regulations, it would be most pragmatic if the dose of ENMs consisting of the same chemical composition could be characterised with fewer parameters than would be needed to uniquely describe all NPS in the ENM, i.e. by means of a reduced dose metric. Removing some of the parameters from the dose description can be justified if, for example, the role of some NP properties in the induced response is negligible compared to that of others. Alternatively, certain particle properties influencing the response may be uniquely related, such as particle size with surface area, reactivity and solubility, in such a way that only one parameter combining these properties needs to be included in the dose metric of all ENMs of the same chemical composition. Justification of the use of such a reduced dose metric should first be established by experimental study.

In the current study, a practical method is presented to determine whether the use of a reduced dose metric for solid, spherical ENMs consisting of the same chemical composition can be justified. As an illustration, the method is applied to analyse results from in vitro experiments with $\mathrm{SiO}_{2}$ and $\mathrm{Ag}$ NPs described in Chapter 5 and 6 and published previously (Park et al. 2011a; b). Recommendations for experimentalists are provided so that information on the reduced dose metric can be extracted with highest confidence. The approach offers opportunities for large research programmes such as the OECD Sponsorship programme and European FP7 projects to analyse the field of application of a reduced metric and thereby the relevance for application in risk assessment and regulatory purposes.

\subsection{MATHEMATICAL BASIS FOR A METHOD TO ASSESS DOSE METRICS IN EXPERIMENT}

To study properties of a dose metric systematically, one can make use of the criterion that equal doses (specified in the appropriate metric) should give an equal response in the system. The experiments involve testing a range of NMs that vary both in particle number and in NM properties (e.g. size, shape, $\zeta$-potential) for their ability to give rise to a specified response in a defined system. For each NM in this range, the dose that gives rise to this response is to be identified, where the NM dose is expressed in parameters such as number of NPs, diameter, etc. The relation between the equi-response doses of this range of NMs can be mathematically described by a surface on which the responses are equal 
(equi-response surface). When only two parameters are required, this surface is reduced to an equi-response curve. The mathematical description of this surface or curve may be used to identify a reduced dose metric, if it exists.

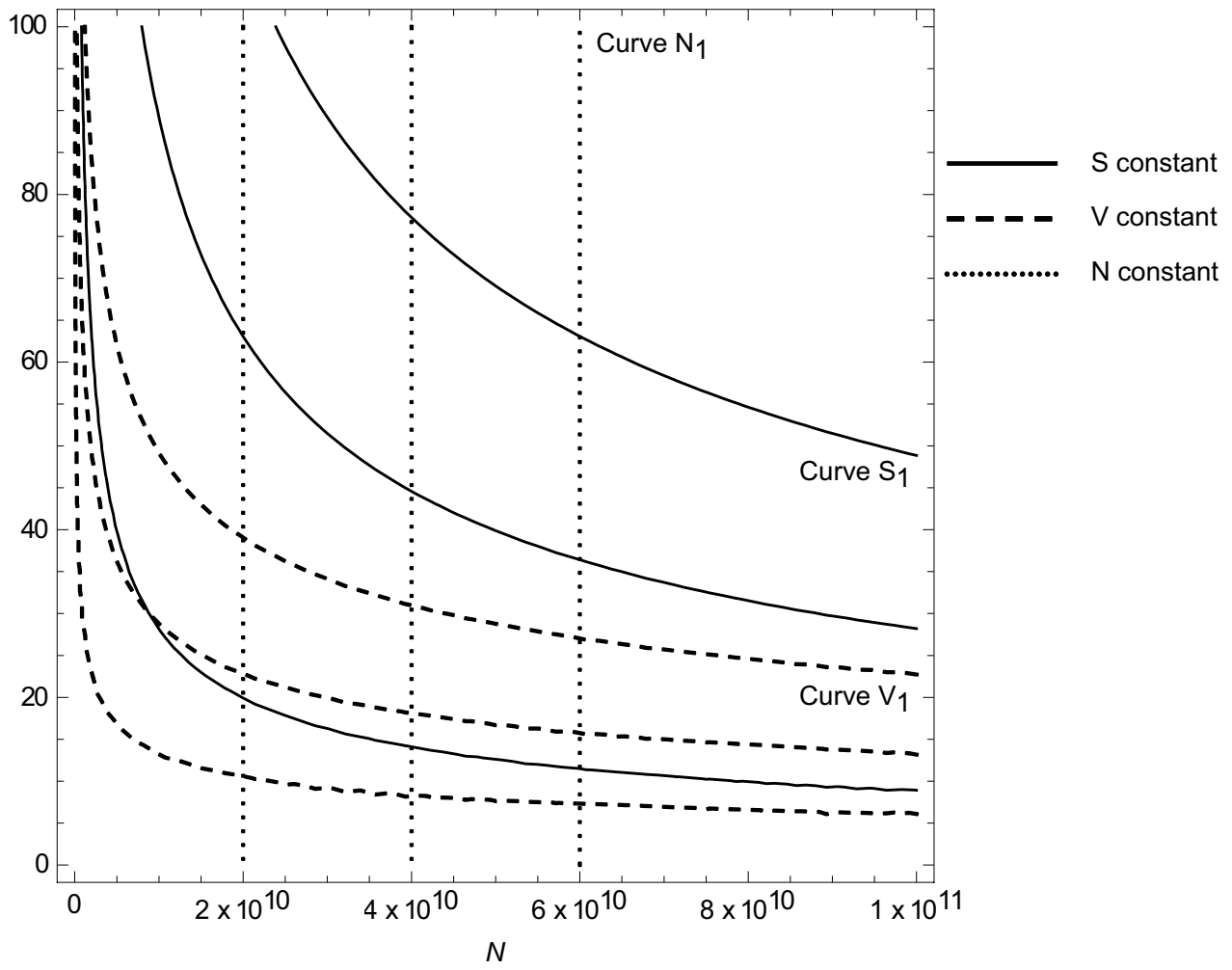

Figure 7.1 Curves for constant surface area, volume and number of particles based on a specific dose of $N$ particles of diameter $d$. For example, curve $S_{1}$ shows that $1 \times 10^{11}$ particles with of diameter of $50 \mathrm{~nm}$, but also $4 \times 10^{10}$ particles with a diameter of $80 \mathrm{~nm}$ have a constant surface area $\mathrm{S}_{1}$. Similarly, the curve for a constant volume $V_{1}$ can be obtained with approximately $1 \times 10^{11}$ particles with a diameter of $25 \mathrm{~nm}$, but also with approximately $2 \times 10^{10}$ particles with a diameter of $40 \mathrm{~nm}$, while the constant particle number $\mathrm{N}_{1}$ (in this case, $6 \times 10^{10}$ particles) is independent of the diameter of the particles. The existence of a reduced dose metric like administered surface area $S$, administered volume $V$ and total number of particles administered $N$ for nanoparticles would lead to equi-response curves of constant $S, V$ or $N$. Note that if such equi-response curves exist, this would reduce the number of parameters required to describe the dose from two ( $N$ and $d$ ) to one $(S, V$ or just $N)$.

To illustrate the use of equi-response surfaces to analyse dose metrics with a theoretical example, the relatively simple (but common) case of NMs consisting of solid, spherical particles is considered. A simple way of presenting the dose of these NPs is to express them in two parameters: number of particles $N$ and particle diameter $d$. Equi-respons doses of a range of solid, spherical NPs with different diameters can then be presented in 
an $(N, d)$ plot, i.e. $N$ NPs of diameter $d$ required to induce a specified equi-response. If a dose-metric based on $N$ and $d$ is adequate, it will be possible to generate an equi-response curve, connecting all equi-response doses.

To test whether any of the reduced dose metrics particle number, particle volume or particle surface area is an appropriate dose metric for the ENM in the experimental system, the shape of the equi-response curves obtained from the experimental data can be compared to the curves of constant total particle surface area $S$, constant particle volume $V$ and constant number of particles $N$ (Figure 7.1).

The surface area of one sphere can be given by the following formula:

$$
S=\pi \times d^{2}
$$

where $d$ is the diameter of the sphere. It follows that the curve for constant total surface area of $N$ particles is:

$$
S=N \times \pi \times d^{2}=\text { constant }
$$

and thus:

$$
N=\frac{c_{1}}{d^{2}}
$$

where $c_{1}$ is a particular constant incorporating $\pi$ that depends on the response level. Taking the logarithm (base 10) of both sides of the equation allows for a more convenient comparison of the curves:

$$
\log (N)=\log \left(c_{1}\right)-2 \log (d)
$$

Or:

$$
\log (N)=c_{2}-2 \log (d)
$$

Note that the logarithmic equation describing the curve for constant surface area takes the form of the equation describing a straight line:

$$
y=a x+b
$$

where $a$ is the slope of the line and $b$ a particular constant. It follows that the logarithmic equation describing the curve for constant surface area has a slope that equals -2 . 
In a similar way, the logarithmic equation describing the curve for constant volume can be derived. The volume of a sphere can be given by the formula:

$$
V=\pi \times \frac{d^{3}}{6}
$$

The constant total volume of $N$ particles is given by

$$
V=N \times \pi \times \frac{d^{3}}{6}=\text { constant }
$$

and thus:

$$
\log (N)=c_{4}-3 \times \log (d)
$$

It follows that the logarithmic equation describing the curve for constant volume has a slope of -3 .

Finally, the curve of constant particle number $N$ is independent of diameter $d$ and is given by

$$
N=\text { constant }
$$

Or:

$$
\log (N)=c_{5}
$$

It follows that the logarithmic equation describing the curve for constant particle number has a slope of 0 .

Plots of equi-response curves may be used to directly verify whether a reduced dose metric exists and if it does, whether administered number of particles, administered surface area or volume are appropriate dose metrics. For example, if the slope of the equiresponse curve in the $\log (N), \log (d)$ plot equals -2 , it will be parallel to that of the constant surface area curve. In other words, the $\mathrm{EC}_{20}$ values will decrease proportionally to the NP surface area, implying that total administered surface area is a complete dose description. If, on the other hand, the slope equals 0 , total number of particles is a complete dose description, and if it equals -3 , it is volume or mass.

\subsection{APPLICATION OF THE METHOD TO EXPERIMENTAL DATA}

The method was applied to data obtained from a number of experimental in vitro doseresponse systems with $\mathrm{SiO}_{2}$ and $\mathrm{Ag}$ NPs described in Chapter 5 and 6 (Figure 7.2 and 7.3). 
Only those experiments were selected for which $\mathrm{EC}_{20}$ concentrations could be calculated for all particle sizes.

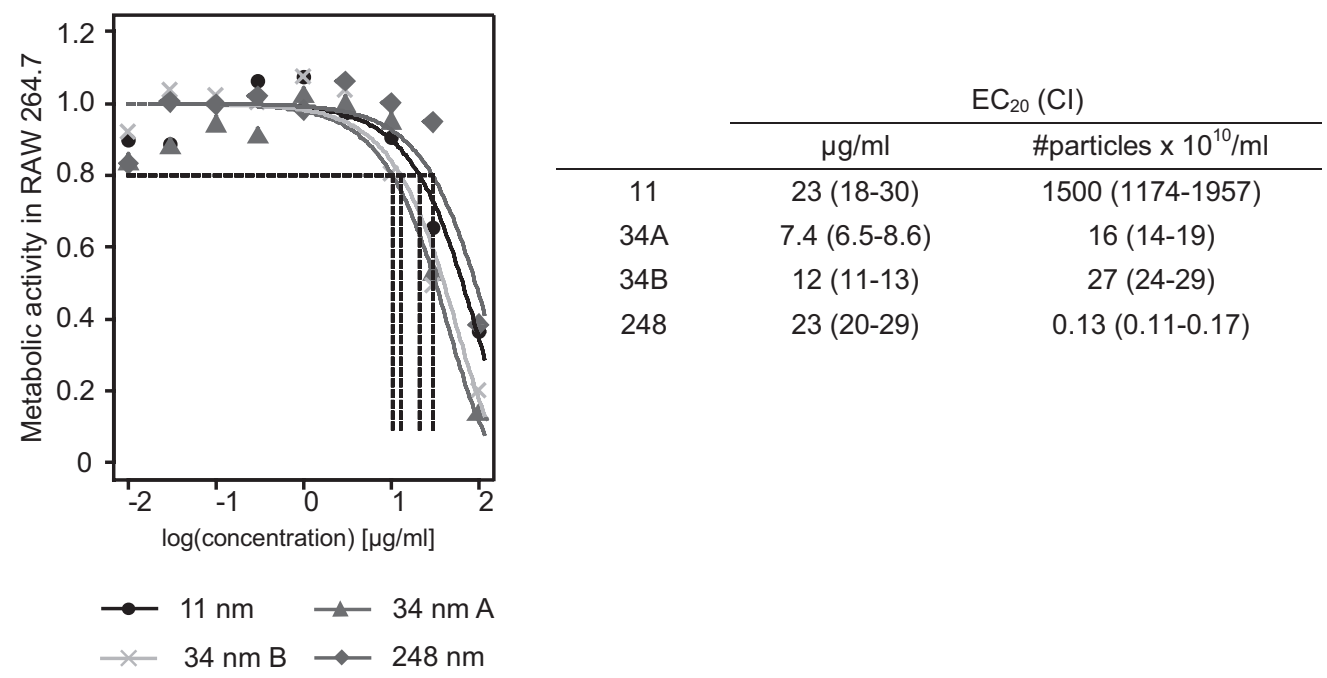

Figure 7.2 Dose response curves and $20 \%$ effect concentrations $\left(\mathrm{EC}_{20}\right)$ plus confidence intervals $(\mathrm{Cl})$ of the decrease in metabolic activity of RAW 264.7 macrophages for $\mathrm{SiO}_{2}$ NPs of $11 \mathrm{~nm}, 34 \mathrm{~nm}$ (A and B) and $248 \mathrm{~nm}$.

For practical reasons, experiments with ENMs are generally performed using mass as an initial dose metric. Since both $\mathrm{SiO}_{2}$ and $\mathrm{Ag} \mathrm{NPs}$ are spherical, with known diameter and mass density, the nominal mass-based $\mathrm{EC}_{20}$ equi-response concentrations, specified in experiment as $\mu \mathrm{g} / \mathrm{ml}$, can be converted to a number based concentration $C_{N}$ :

$$
C_{N}=C_{M} \times \frac{6}{\pi \rho d^{3}}
$$

The variation in TEM measured diameters of the NPs was negligible for the conversion to particle number concentrations. The log (base 10) of the number $N$ of particles administered per millilitre was plotted against the log of the particle's diameter for all response levels. To test whether a simple reduced dose metric adequately describes the data, a linear model:

$$
\log (N)=a+b \times \log (d)
$$

was fit to the data by means of a least squares minimization principle. 

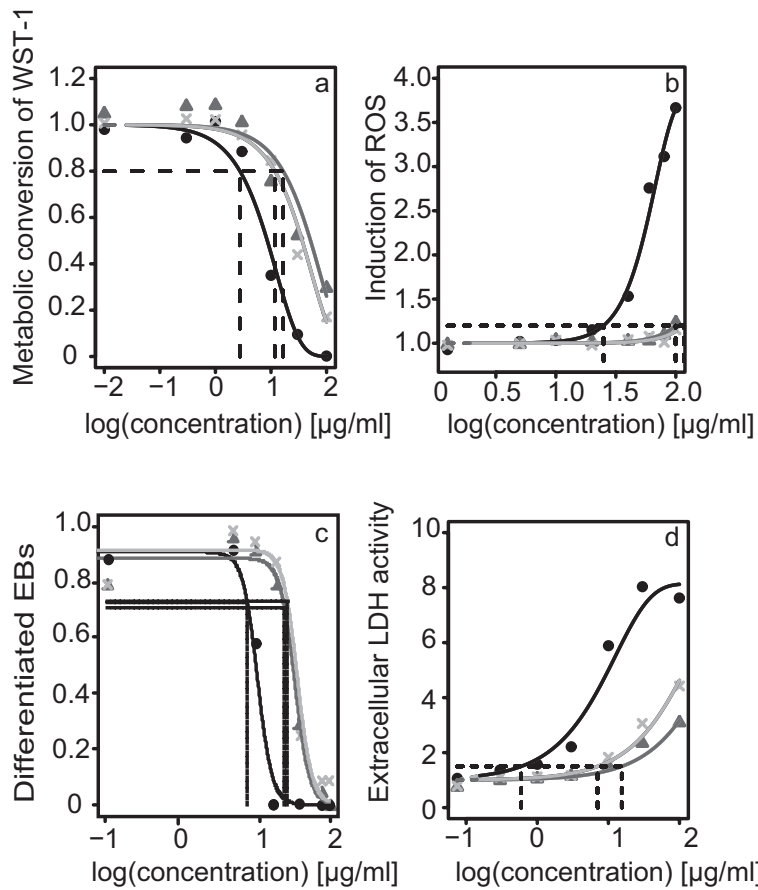

$\rightarrow 20 \mathrm{~nm} \rightleftharpoons 80 \mathrm{~nm} \nsim 113 \mathrm{~nm}$

\begin{tabular}{ccc} 
& \multicolumn{2}{c}{ EC20 $(\mathrm{Cl})$} \\
\cline { 2 - 3 } & $\mu \mathrm{g} / \mathrm{ml}$ & \#particles $\times 10^{10} / \mathrm{ml}$ \\
\hline WST-1 in L929 & & \\
20 & $2.8(2.7-2.9)$ & $6.4(6.1-6.6)$ \\
80 & $17(15-18)$ & $0.60(0.53-0.64)$ \\
113 & $12(11-13)$ & $0.15(0.14-0.16)$ \\
ROS in RAW 264.7 & & \\
20 & $25(22-28)$ & $57(50-64)$ \\
80 & $100(89-116)$ & $3.6(3.2-4.1)$ \\
113 & $117(103-140)$ & $1.5(1.3-1.8)$ \\
EST in D3 & & \\
20 & $12(10-13)$ & $27(23-30)$ \\
80 & $31(26-37)$ & $1.1(0.9-1.3)$ \\
113 & $29(26-32)$ & $0.37(0.33-0.40)$ \\
LDH in L929 & & \\
20 & $0.20(0.13-0.28)$ & $0.46(0.30-0.64)$ \\
80 & $5.2(2.3-8.0)$ & $0.19(0.082-0.28)$ \\
113 & $2.4(1.6-3.1)$ & $0.030(0.020-0.039)$
\end{tabular}

Figure 7.3 Dose-response curves and table with $20 \%$ effect concentrations $\left(\mathrm{EC}_{20}\right)$ plus confidence intervals $(\mathrm{Cl})$ for Ag NPs of $20 \mathrm{~nm}, 80 \mathrm{~nm}$ and $113 \mathrm{~nm}$, from different in vitro test systems: Decrease in metabolic activity of L929 fibroblasts (a), induction of reactive oxygen species (ROS) in RAW 264.7 macrophages (b), inhibition of embryonic stem cell differentiation (c) and decreased membrane integrity of L929 fibroblasts (d). 
The existence of a reduced dose metric was considered plausible if the $R^{2}$ value of the equiresponse curve in the $\log (N), \log (d)$ plot was larger than 0.95 . Particle number, surface area and volume were considered adequate dose metrics if the $95 \%$ confidence interval around the slope of the equi-response curve included $0,-2$ and -3 , respectively.

\subsection{RESULTS}

The regression curve for the test system measuring metabolic activity (WST-1) of RAW 264.7 macrophages in response to $\mathrm{SiO}_{2} \mathrm{NPs}\left(\mathrm{R}^{2}\right.$ of 0.97$)$ suggests a linear relation between $\log (N)$ and $\log (d)$ for the doses along the equi-response curve, indicating that a reduced dose metric indeed exists (Figure 7.4).

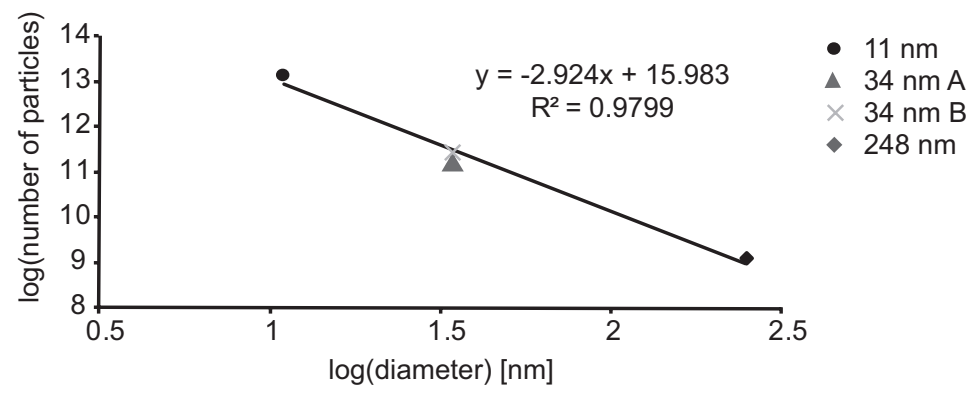

Figure 7.4 The equi-response curve for $\mathrm{SiO}_{2} \mathrm{NPs}$ in RAW264.7 macrophages. On a $\log (N)$ versus $\log (d)$ scale the equi-response curves describe a straight line, indicating the existence of a reduced dose metric. The slope of the curve can be used to infer the form of this reduced metric and a slope of approximately -3 suggests that total mass (or volume with constant density) administered is an adequate dose descriptor.

For Ag NPs, the regression line for all experimental systems except for membrane integrity (LDH) in $L 929$ fibroblasts also suggests the existence of a reduced dose metric $\left(R^{2}\right.$ of $>0.95$ ) (Figure 7.5). For membrane integrity of L929 fibroblasts, the data did not fit a linear regression line ( $R^{2}$ of 0.75$)$, indicating that a reduced dose-metric is not adequate for this test system and these NPs. Alternatively, the relation between $\log (N)$ and $\log (d)$ along the equi-response curve can be described by a non-linear function, in which case a reduced dose-metric related to NP diameter may still be adequate.

The slope of the linear regression lines (parameter $b$ ) for the experimental systems gives an indication of what the simple reduced dose metric may be (Table 7.1). Analyses of the slope $b$ of -2.9 of the dose-response relation in the test system for metabolic activity in RAW 264.7 macrophages suggest that the dose of $\mathrm{SiO}_{2} \mathrm{NPs}$ is best expressed in administered volume. Since the ENM consists of solid, spherical NPs of similar primary sizes, it can be assumed that the volume of this ENM has a constant density, implying that the dose may also be expressed in mass. In contrast, both the dose-response relation for Ag NPs in the test systems for metabolic 
activity in L929 fibroblasts $(b=-2.0)$ and induction of ROS in RAW 264.7 macrophages ( $b=$ -2.1) are best described by specifying dose in administered surface area.
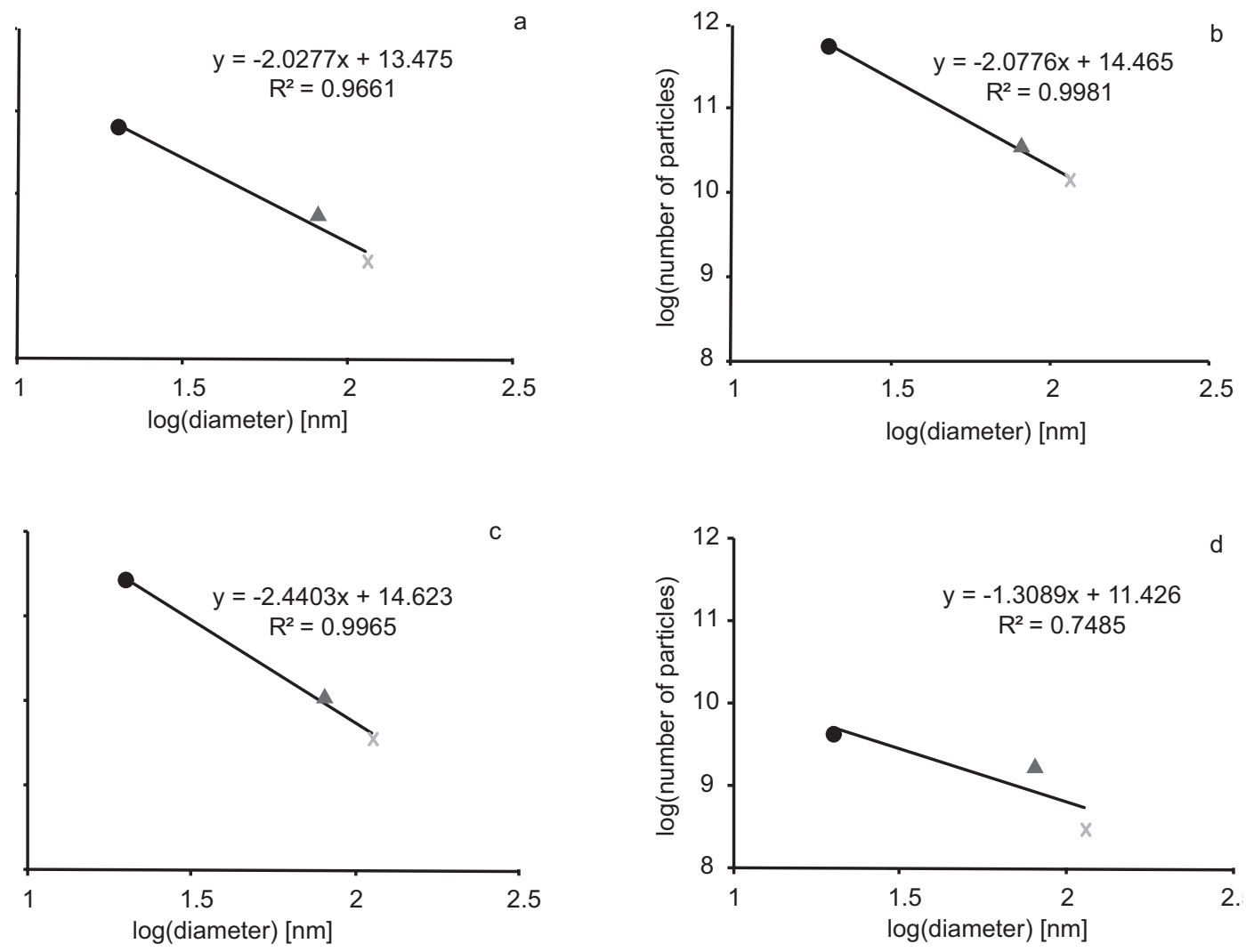

- $20 \mathrm{~nm} \quad \Delta \quad 80 \mathrm{~nm} \times 113 \mathrm{~nm}$

Figure 7.5 The equi-response curve for Ag NPs for metabolic activity in L929 fibroblasts (a), induction of ROS in RAW264.7 macrophages (b), inhibition of stem cell differentiation (c) and membrane integrity in L929 fibroblasts (d).

\begin{tabular}{llll} 
ENM & Test system & $\mathbf{R}^{2}$ & $\boldsymbol{b}$ \\
\hline $\mathrm{SiO}_{2}$ & WST-1 RAW264.7 macrophages & 0.98 & $-2.91(-3.03$ to -2.79$)$ \\
$\mathrm{Ag}$ & WST-1 in L929 fibroblasts & 0.97 & $-2.05(-2.11$ to -2.00$)$ \\
$\mathrm{Ag}$ & ROS in RAW 264.7 macrophages & 1.00 & $-2.06(-2.19$ to -1.93$)$ \\
$\mathrm{Ag}$ & EST in D3 embryonic stem cells & 1.00 & $-2.41(-2.53$ to -2.29$)$ \\
$\mathrm{Ag}$ & LDH in L929 fibroblasts & 0.75 & $-1.34(-1.71$ to -0.98$)$ \\
\hline
\end{tabular}

Table 7.1 Summary of the slope of the equi-response curves in a $\log (\mathrm{N})$ versus $\log (\mathrm{d})$ plot, plus $95 \%$ confidence intervals, determined from the $90 \%$ confidence intervals of the respective dose-response models by bootstrapping. 
The slope $b$ of -2.4 of the dose-response relation of Ag NPs for inhibition of differentiation in embryonic stem cells indicates that the dose can be described by a parameter related to the diameter of the NPs, but not administered surface area or volume (mass). To illustrate how this type of reduced dose metric can be applied in practice, we consider the response of Ag NPs inhibiting embryonic stem cell differentiation by $20 \%$ compared to control. The regression line to the logarithmic $20 \%$ response curve in the $\log (\mathrm{d}), \log (\mathrm{N})$ plot, derived from the EST experiments with the 20, 80 and $113 \mathrm{~nm} \mathrm{NPs}$, had the following equation:

$$
\begin{aligned}
& y=-2.4 x+14.6, \text { or: } \\
& \log (N)=-2.4 \times \log (d)+14.6, \text { or: } \\
& N=d^{-2.4} \times 10^{14.6}
\end{aligned}
$$

In other words, the dose metric is $N x d^{2.4}$, and for ENMs consisting of similar Ag NPs with any distribution of sizes, the dose that will inhibit embryonic stem cell differentiation by $20 \%$ is $10^{14.6} \mathrm{Nx}^{2.4}$. Taking this exercise one step further, we can consider two fictive ENMs consisting of similar, solid, spherical Ag NPs, but differing in their average primary sizes and size distributions; Ag NPs of $17 \mathrm{~nm}$ and Ag NPs of $60 \mathrm{~nm}$ (Figure 7.6). We have previously determined that our monodisperse Ag NPs of $20 \mathrm{~nm}$ inhibited stem cell differentiation by $20 \%$ compared to control at a dose of $2.7 \times 10^{11} \mathrm{NPs}$. We can now calculate whether exposure to the same number of NPs of our two fictive ENMs with different size distributions will exceed this critical dose. Based on the size distributions, we can convert every fraction of $N$ with diameter $d$ to the dose metric $N x d^{2.4}$ and determine its sum, i.e. the dose of NPs in $N \times d^{2.4}$.

For the $17 \mathrm{~nm} \mathrm{Ag} \mathrm{NPs}$, a dose of $2.7 \times 10^{11}$ converts to $6.7 \times 10^{14} \mathrm{Nx} \mathrm{d}^{2.4}$, while a dose of $2.7 \times 10^{11} \mathrm{Ag}$ NPs of $60 \mathrm{~nm}$ converts to $6.2 \times 10^{15} \mathrm{Nxd^{2.4 }}$. These doses can be compared to the critical dose of $1 \times 10^{14.6} \mathrm{Nxd^{2.4 }}$ by taking the log (base 10), resulting in 14.8 and 15.8 for $17 \mathrm{~nm}$ and $60 \mathrm{~nm}$ Ag NPs, respectively, compared to 14.6 for the critical dose. In other words, for both ENMs, a dose of $2.7 \times 10^{11}$ exceeds the dose that will inhibit stem cell differentiation by $20 \%$ compared to control.

\subsection{DISCUSSION}

The current Chapter presents a method to study dose metrics of NPs by means of equiresponse plots, which was successfully applied to a number of experimental systems and ENMs. In four out of five cases, the observations indicated the existence of a reduced dose metric related to particle diameter, albeit not the same dose metric for all ENMs and systems considered. In three of the illustrative examples, the dose metric required only one 
parameter to completely describe the dose of the ENM considered: either surface area or mass. For the inhibition of stem cell differentiation by Ag NPs, the dose could be completely described by two parameters: number of NPs and NP diameter. The simple graphical method is also applicable when the number of NP characteristics required to completely describe a dose is three, in which case equi-response surfaces can be constructed using an extra axis in the plot. If more than three NP characteristics are required, the principle of constructing equi-response surfaces and analyzing the mathematical relation between doses on these surfaces is still an appropriate method to identify reduced metrics for the dose, but this cannot easily be demonstrated in a graphical way.

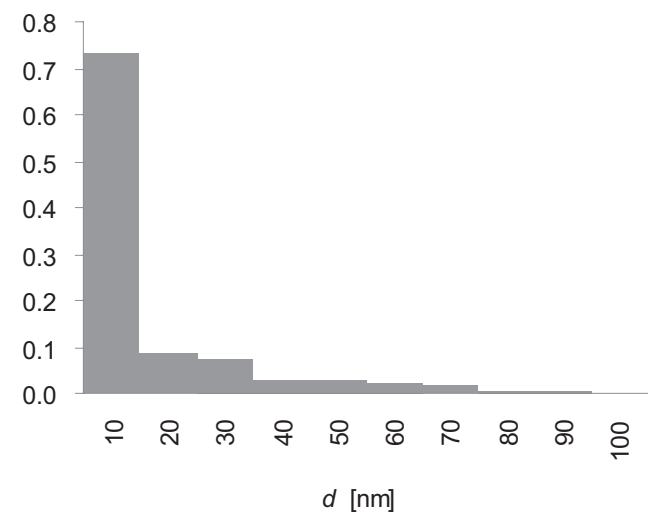

\begin{tabular}{cccc}
\hline$d[\mathrm{~nm}]$ & Fraction of $N$ & $N$ & $N x d^{2.4}$ \\
\hline 10 & 0.73 & $1.99 \mathrm{E}+11$ & $5.00 \mathrm{E}+13$ \\
20 & 0.09 & $2.41 \mathrm{E}+10$ & $3.20 \mathrm{E}+13$ \\
30 & 0.07 & $2.01 \mathrm{E}+10$ & $7.05 \mathrm{E}+13$ \\
40 & 0.03 & $8.04 \mathrm{E}+09$ & $5.63 \mathrm{E}+13$ \\
50 & 0.03 & $8.04 \mathrm{E}+09$ & $9.61 \mathrm{E}+13$ \\
60 & 0.02 & $6.03 \mathrm{E}+09$ & $1.12 \mathrm{E}+14$ \\
70 & 0.01 & $4.02 \mathrm{E}+09$ & $1.08 \mathrm{E}+14$ \\
80 & 0.01 & $2.01 \mathrm{E}+09$ & $7.43 \mathrm{E}+13$ \\
90 & 0.01 & $1.41 \mathrm{E}+09$ & $6.90 \mathrm{E}+13$ \\
100 & 0.00 & $0.00 \mathrm{E}+00$ & $0.00 \mathrm{E}+00$ \\
\hline Sum & 1.00 & $2.73 \mathrm{E}+11$ & $6.68 \mathrm{E}+14$ \\
\hline
\end{tabular}

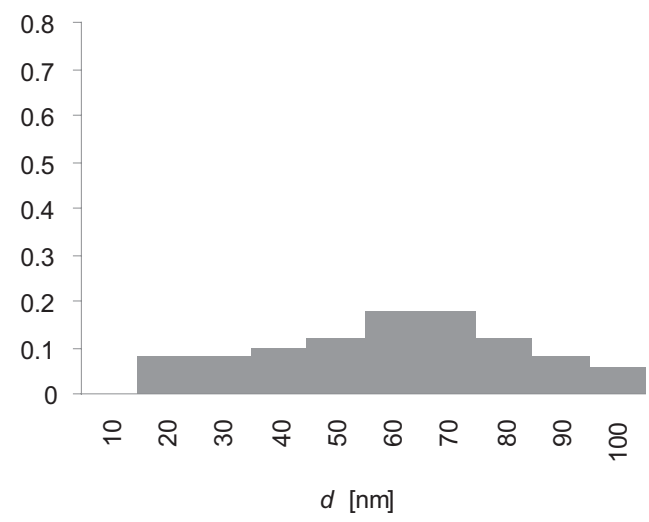

\begin{tabular}{cccc}
\hline$d[\mathrm{~nm}]$ & Fraction of $N$ & $N$ & $N x d^{2.4}$ \\
\hline 10 & $\mathbf{0}$ & $0.00 \mathrm{E}+00$ & $0.00 \mathrm{E}+00$ \\
20 & 0.08 & $2.18 \mathrm{E}+10$ & $2.89 \mathrm{E}+13$ \\
30 & 0.08 & $2.18 \mathrm{E}+10$ & $7.66 \mathrm{E}+13$ \\
40 & 0.1 & $2.73 \mathrm{E}+10$ & $1.91 \mathrm{E}+14$ \\
50 & 0.12 & $3.27 \mathrm{E}+10$ & $3.91 \mathrm{E}+14$ \\
60 & 0.18 & $4.91 \mathrm{E}+10$ & $9.09 \mathrm{E}+14$ \\
70 & 0.18 & $4.91 \mathrm{E}+10$ & $1.32 \mathrm{E}+15$ \\
80 & 0.12 & $3.27 \mathrm{E}+10$ & $1.21 \mathrm{E}+15$ \\
90 & 0.08 & $2.18 \mathrm{E}+10$ & $1.07 \mathrm{E}+15$ \\
100 & 0.06 & $1.64 \mathrm{E}+10$ & $1.03 \mathrm{E}+15$ \\
\hline Sum & 1.00 & $2.73 \mathrm{E}+11$ & $6.23 \mathrm{E}+15$ \\
\hline
\end{tabular}

Figure 7.6 Size distributions for two fictive ENMs consisting of Ag NPs with average primary diameters of 17 $\mathrm{nm}$ (a) and $60 \mathrm{~nm}(\mathrm{~b})$, and conversion of a dose of $2.7 \times 10^{11} \mathrm{NPs}$ to a dose in $\mathrm{Nx} / d^{2.4}$, for comparison with the critical dose of $10^{14.6} \mathrm{Nxd}^{2.4}$, which inhibits stem cell differentiation by $20 \%$ compared to control.

In all experimental systems analyzed, the number of particle sizes within one particle type (i.e. one chemical composition) was limited to a maximum of three, within the size range of $20 \mathrm{~nm}$ 
and $113 \mathrm{~nm}$ for Ag NPs and $11 \mathrm{~nm}$ and $248 \mathrm{~nm}$ for $\mathrm{SiO}_{2}$ NPs. As a result, equi-response curves were inferred on the basis of relatively sparse observations. Despite this, the method proved to be useful in most cases, as it quickly pointed to whether a reduced dose metric existed and what it might be. Only for the test system membrane integrity in L929 fibroblasts, the existence of a reduced dose metric could neither be confirmed nor refuted due to insufficient data points. In general, identification of an adequate dose metric, especially in more complex cases, will always benefit from including more equi-response data by investigating a larger range of ENMs varying in one characteristic such as particle size.

Another issue to consider when designing experiments to analyze dose metrics is the fact that in practice, most ENMs will consist of NPs with a distribution of characteristics (for example, particle diameters) rather than having a single well-defined value for this characteristic. Preferably, for the purpose of studying dose metrics, distributions of NP properties within an ENM should be as narrow as possible. Ideally, changes in NP properties during exposure and information on the differences between nominal and actual exposure concentrations should also be taken into account when deriving an appropriate dose-metric, although the techniques to quantify this information may not always be available yet.

For the time being, we can only speculate on the reasons for the differences in appropriate dose metrics between different test systems and between Ag NPs compared to $\mathrm{SiO}_{2}$ NPs. First of all, appropriate dose metrics may have been affected by experimental conditions. For example, while we have found that the appropriate dose metric for $\mathrm{SiO}_{2}$ NPs reducing metabolic activity of RAW 264.7 is mass, others have found that surface area determined the effects on cellular metabolic activity by $\mathrm{SiO}_{2}$ NPs (Napierska et al. 2009; Waters et al. 2009). The experimental conditions in these studies were rather similar to ours, except for the fact that we added fetal calf serum to the cell culture medium. The presence of proteins in cell culture medium directly affects the aggregation status of NMs and potentially also their exposure levels (Hinderliter et al. 2010; Murdock et al. 2008). The protein layer forming around the NMs (termed protein corona) has also been suggested to affect uptake levels and biological responses induced by NMs (Lesniak et al. 2010; Lynch et al. 2009). This in turn may have affected the appropriateness of expressing the dose of $\mathrm{SiO}_{2}$ NPs in either mass or surface area. In case of Ag NPs, differences in dose metrics between assays for metabolic activity and ROS induction and for inhibition of stem cell differentiation may have been related to the fact that in the embryonic stem cell test, a complex exposure system and longer incubation time (10 days) is used, which may have led to multiple NP diameter related properties affecting both the exposure level and the response of the stem cells. In short, it needs to be realized that a particular dose metric is only valid under certain (experimental) conditions, and therefore, these conditions need to be clearly defined.

Even when experimental conditions were kept consistent, our data indicate that it is not possible to adequately describe the dose of all ENMs using one and the same reduced dose metric for both $\mathrm{Ag}$ NPs and $\mathrm{SiO}_{2}$ NPs. For decreasing metabolic activity by $\mathrm{Ag} \mathrm{NPs,}$ surface area was the most appropriate dose metric, possibly because a larger surface area 
may lead to a faster release of cytotoxic $\mathrm{Ag}$ ions. In contrast, the $\mathrm{SiO}_{2} \mathrm{NPs}$ were not as soluble and especially the smaller $\mathrm{SiO}_{2} \mathrm{NPs}$ were quite aggregated in cell culture medium (Park et al. 2009). This may have led to exposure levels and cell responses that, based on volume or mass concentrations, were comparable across sizes.

Although it may not be possible to use the same dose metric for all different types of ENM, the existence of a reduced dose metric related to the NP diameter for both types of NPs in most of our in vitro experiments is a first indication that it may be possible to derive a single dose metric for ENMs of the same chemical composition, but with different diameters. This still has the advantage that it can be applied to ENMs consisting of NPs with different size distributions. In addition, further systematic research into appropriate dose metrics of a wide variety of ENMs may help to group ENMs of different chemical compositions for which similar dose metrics can be used.

Applying an in vitro derived reduced dose metric for exposure limits for an ENM does need to consider quantitative biodistribution and clearance information on the ENM in target tissues in the body or in target species in the environment. The in vivo distribution of the Ag NPs used in the illustrative examples has been quantified using a physiologically based pharmacokinetic (PBPK) model and demonstrated that tissue distribution patterns were different for NPs of different diameters (Lankveld et al. 2010). For a reduced dose metric such as surface area to be useful in this situation, exposure limits are best derived based on local target tissue concentrations rather than nominal administered concentrations.

Another important issue to address before applying a single dose metric in risk evaluations of multiple ENMs is that in our studies with Ag NPs, different dose metrics were found to be appropriate for different biological responses. While total administered surface area was an adequate dose metric to describe a decrease in metabolic activity by Ag NPs, it was not an adequate dose metric for compromising membrane integrity, despite the fact that the exact same experimental conditions were used. In addition, we have demonstrated before that $\mathrm{SiO}_{2}$ NPs 34A and 34B had comparable effect concentrations (based on mass) in cytotoxicity studies, while in the very same experiments, only 34A NPs were found to induce cytokines (Park et al. 2011a). These results imply that different biological responses are affected by different NP characteristics and thus require different metrics to adequately describe the dose.

In summary, a novel, practical and mathematically founded method was presented to systematically study the question of what might be an appropriate dose metric for ENMs. To illustrate this method, it was applied to data from various in vitro assays with $\mathrm{Ag}$ and $\mathrm{SiO}_{2}$ NPs of different sizes and based on this, we conclude that finding the appropriate dose metric may be affected by experimental conditions, but it is also dependent on ENM chemical composition and the biological response considered. The approach provides opportunities to systematically investigate the dose metric that can describe toxic effects of series ENMs with different characteristics, enabling to draw conclusions on the use of specific dose metrics for risk assessment and regulatory purposes. 


\section{REFERENCES}

Clift MJ, Varet J, Hankin SM, Brownlee B, Davidson AM, Brandenberger C, Rothen-Rutishauser B, Brown DM, Stone V. 2011. Quantum dot cytotoxicity in vitro: An investigation into the cytotoxic effects of a series of different surface chemistries and their core/shell materials. Nanotoxicology 5:664-74.

Duffin R, Tran L, Brown D, Stone V, Donaldson K. 2007. Proinflammogenic effects of low-toxicity and metal nanoparticles in vivo and in vitro: highlighting the role of particle surface area and surface reactivity. Inhal Toxicol 19(10):849-56.

Hinderliter PM, Minard KR, Orr G, Chrisler WB, Thrall BD, Pounds JG, Teeguarden JG. 2010. ISDD: A computational model of particle sedimentation, diffusion and target cell dosimetry for in vitro toxicity studies. Part Fibre Toxicol 7(1):36.

Lankveld DP, Oomen AG, Krystek P, Neigh A, Troost-de Jong A, Noorlander CW, Van Eijkeren JC, Geertsma RE, De Jong WH. 2010. The kinetics of the tissue distribution of silver nanoparticles of different sizes. Biomaterials 31(32):8350-8361.

Lesniak A, Campbell A, Lynch I, Salvati A, Dawson KA. 2010. Serum heat inactivation affects protein corona composition and nanoparticle uptake. Biomaterials 31(36):9511-9518.

Lynch I, Salvati A, Dawson KA. 2009. Protein-nanoparticle interactions: What does the cell see? Nat Nanotechnol 4(9):546-7.

Murdock RC, Braydich-Stolle L, Schrand AM, Schlager JJ, Hussain SM. 2008. Characterization of nanomaterial dispersion in solution prior to in vitro exposure using dynamic light scattering technique. Toxicol Sci 101(2):239-253.

Napierska D, Thomassen LC, Rabolli V, Lison D, Gonzalez L, Kirsch-Volders M, Martens JA, Hoet PH. 2009. Size-dependent cytotoxicity of monodisperse silica nanoparticles in human endothelial cells. Small 5(7):846-53.

Park MVDZ, Annema W, Salvati A, Lesniak A, Elsaesser A, Barnes C, McKerr G, Howard CV, Lynch I, Dawson KA et al. 2009. In vitro developmental toxicity test detects inhibition of stem cell differentiation by silica nanoparticles. Toxicol Appl Pharmacol 240:108-116.

Park MVDZ, Lynch I, Ramírez-García S, Dawson KA, de la Fonteyne L, Gremmer E, Briedé JJ, Slob W, Elsaesser A, Howard CV et al. 2011a. In vitro evaluation of cytotoxic and inflammation properties of silica nanoparticles of different sizes in murine RAW 264.7 macrophages. J Nanopart Res 13(12):6775-6787.

Park MVDZ, Neigh AM, Vermeulen JP, de la Fonteyne LJ, Verharen HW, Briede JJ, van Loveren H, de Jong WH. 2011b. The effect of particle size on the cytotoxicity, inflammation, developmental toxicity and genotoxicity of silver nanoparticles. Biomaterials 32(36):9810-7.

Poland CA, Byrne F, Cho WS, Prina-Mello A, Murphy FA, Davies GL, Coey JM, Gounko Y, Duffin R, Volkov $Y$ et al. 2011. Length-dependent pathogenic effects of nickel nanowires in the lungs and the peritoneal cavity. Nanotoxicology.

Schaeublin NM, Braydich-Stolle LK, Schrand AM, Miller JM, Hutchison J, Schlager JJ, Hussain SM. 2011. Surface charge of gold nanoparticles mediates mechanism of toxicity. Nanoscale 3(2):410-20.

Waters KM, Masiello LM, Zangar RC, Tarasevich BJ, Karin NJ, Quesenberry RD, Bandyopadhyay S, Teeguarden JG, Pounds JG, Thrall BD. 2009. Macrophage responses to silica nanoparticles are highly conserved across particle sizes. Toxicol Sci 107(2):553-69. 



\section{CHAPTER 8}

SUMMARIZING DISCUSSION AND FUTURE PERSPECTIVES 



\subsection{INTRODUCTION}

With the steady progression of nanotechnology, many new nanotechnology based applications enter the market, including every day consumer products containing ENMs. This development can be anticipated to lead to chronic and increasing human exposure levels to an ever expanding variety of ENMs, justifying a thorough investigation into their possible adverse effects.

Due to their physicochemical properties, ENMs appear to have different biological activities compared to the bulk material. For example, NPs have the capability to cross biological barriers and reach cells and tissues which were not exposed by their macroscopic form. In Chapter 1, an overview was given on the current state of knowledge of the potential risks of ENMs for human health. Distribution and persistance of ENMs in the body are important factors that influence these risks, but insufficient knowledge exists to predict the behaviour of ENMs in the body based on their physicochemical properties. There is a fair understanding of some of the mechanisms underlying ENM toxicity, mainly related to the induction of cellular oxidative stress, inflammation signalling and cell membrane damage. Most knowledge on adverse effects of ENMs pertains to local inflammation in the lungs after short term exposure, but there are also clear indications that after both inhalation and oral exposure, ENMs can become systematically available. Studies investigating the long-term effects of ENMs are virtually lacking altogether.

Due to their specific nano-related properties, risk evaluations of ENMs for human health cannot directly be based on the risk evaluations of bulk materials, but rather should be assessed separately, and include an evaluation of potential systemic effects. However, the rate of development of new ENMs will soon outrun the ability to accomplish a thorough risk assessment of every single new ENM when traditional risk assessment procedures based on an array of experimental animal tests continue to be used. Faster approaches for prioritizing ENMs in terms of their hazardous effects are urgently needed. In addition, it would be beneficial to identify NP characteristics that may play a role in eliciting hazardous effects. This information could potentially be used to extrapolate safety data from one nano-form to another, as well as provide a foundation for the development of safe new ENMs.

\subsection{AIM OF THE THESIS}

The aim of this thesis was to aid regulators and risk assessors in dealing with the safety evaluation of a vast variety of existing and newly developed ENMs. This was done with the following three approaches:

1) Evaluate the use of in vitro assays as a screening approach to distinguish between more and less hazardous ENMs. 
2) Investigate the role of NP size in various systemically relevant biological responses, and determine whether safety data from a NP of one particular size can be extrapolated to NPs of another size.

3) Study dose metrics of NPs to evaluate whether one of the dose metrics mass, surface area or particle number is adequate for groups ENMs with different sizes and size distributions.

\subsection{EVALUATION OF IN VITRO ASSAYS FOR THE RISK ASSESSMENT OF ENGINEERED NANOMATERIALS}

In vitro studies have been put forward as a faster approach to screen ENMs on their toxic potential, but uncertainties regarding their suitability for this purpose exist. The first aim of this thesis was to evaluate the use of in vitro assays as a screening approach to do comparative hazard assessment, i.e. to systematically compare the potential of ENMs to induce a certain biological response. As outlined in Chapter 2, a number of factors can be identified that influence the outcome of in vitro studies with ENMs, many of which also apply to the use of in vitro studies for predicting the toxic potential of regular chemicals.

One of the main issues addressed in Chapter $\mathbf{2}$ is that many of the currently used in vitro exposure and dispersion methods may not reflect conditions of in vivo exposure to ENMs. This is probably especially true for assessments of inhalation toxicity, where in vivo exposure to ENMs takes place in the air-liquid interface, while most in vitro test systems use lung epithelial cell cultures submerged in tissue culture medium (Clift et al. 2011). Another difference with in vivo inhalation exposure conditions is that in vitro test systems often make use of serum proteins added to the tissue culture medium, which affect aggregation of NPs and this in turn may affect exposure levels (Murdock et al. 2008). A further consequence of adding these proteins is that they adhere to the surface of NPs, where they are thought to pacify reactive NPs, or otherwise affect their fate and biological impact (Clift et al. 2010; Lundqvist et al. 2008; Lynch et al. 2009). All in all, for studying the effects of NPs after inhalation, submerged in vitro test systems in tissue culture medium containing serum proteins may not be relevant, which has prompted ongoing efforts to develop air-liquid exposure systems (reviewed by Klein et al. 2011). Submerged in vitro test systems in tissue culture medium containing serum proteins may still be relevant for studying systemic effects, where in vivo exposure conditions are 'submerged' and NPs will be coated with proteins as well.Apart from exposure and dispersion methods, the choice of readout system and especially cell type and exposure duration affect the outcome of in vitro assays. In addition, false positive or negative results may originate from poor cell type - assay compatibility or interference of the ENM with the assay. False positive results may also be introduced through (common!) contamination of ENMs with production residues or bacterial endotoxins. 
With all these factors affecting the outcome of in vitro assays with ENMs, it is complicated to compare data from the large number of in vitro studies already published in the literature. Unfortunately, for the same reasons, it is also difficult to determine the most relevant in vitro testing conditions for predicting in vivo effects, and insufficient studies are available that directly compare in vitro with in vivo results. Deriving safe exposure limits for ENMs by extrapolating from in vitro dose response data is, at least for the moment, a bridge too far.

As more in vivo data from studies with ENMs become available, the values and limitations of in vitro assays will be revealed. Based on this information, it will become clearer to what extent in vitro assays can play a role in risk assessment of ENMs. The time where it will be possible to conduct risk assessment solely on the basis of in vitro studies is clearly far ahead due to the fact that in vitro systems for a number of potentially relevant toxicity endpoints such as immunotoxicity, sensitizing potency, reproductive toxicity and non-genotoxic carcinogenicity have not yet been developed, even for regular chemicals. However, when all testing conditions known to affect the outcome of in vitro assays with ENMs are controlled, these assays may still be a useful tool for comparative hazard analysis of ENMs after systemic exposure.

\subsection{THE ROLE OF SILICA AND SILVER NANOPARTICLE SIZE IN VARIOUS SYSTEMICALLY RELEVANT IN VITRO TEST SYSTEMS}

Another approach to reduce the amount of testing needed for ENMs is to extrapolate safety data from one ENM to another. Since particle size is one of the main characteristics varied in the production of ENMs, we investigated whether biological responses to NPs could be predicted by extrapolating across particle sizes. The in vitro test systems used for this purpose were all relevant for responses that may occur when NPs become systemically available, and the factors that affect the outcome of in vitro studies as identified in Chapter $\mathbf{2}$ were controlled in the testing conditions, in order to provide a meaningful comparison of the responses to the various NPs included in these studies.

\subsubsection{In vitro test systems}

The starting point in any meaningful, comparative investigation of biological responses to ENMs is a careful characterization of the material and the test systems (Oberdorster et al. 2005; Warheit 2008). For all NPs included in our studies, we determined the morphology, primary particle size and the concentration, hydrodynamic particle size distribution and surface potential in the buffer in which the particles were provided. The redox potential of the NPs was determined as an indicator of their reactivity. Potentially toxic production residues were removed and the absence of bacterial contaminants was confirmed. Cell cultures were tested and confirmed negative for the presence of mycoplasma. Test 
protocols including incubation times and cell culture conditions were consistent across experiments with all NPs. Test systems based on absorbance and fluorescence signals were investigated and, if needed, corrected for interference with NPs.

A general toxicity endpoint relevant and well investigated for NPs is cytotoxicity, which can be determined using various commercially available in vitro assay kits. Metabolic activity of cells in response to NPs can be investigated using the WST-1 assay, which determines the cellular enzymatic conversion of a tetrazolium salt into a soluble formazan dye. In addition, membrane integrity of cells exposed to NPs can be investigated by determining the activity of LDH leaking out of damaged cells. Both metabolic activity and membrane integrity are widely used biomarkers for cell viability and we used both assays to determine the cell viability of mouse peritoneal macrophages (RAW 264.7) after exposure to NPs of different sizes. Macrophages are well known for their role to clear the body of particulate matter and many in vivo distribution studies have demonstrated that the majority of systemically available NPs end up in macrophage rich organs such as the spleen and liver (De Jong et al. 2008; Lankveld et al. 2010; Lipka et al. 2010; Sadauskas et al. 2007). Representing a more neutral systemic cell type, we have also investigated the size-related effects of NPs on cell viability in mouse fibroblasts (L929).

The induction of oxidative stress has been implicated in many of the adverse effects associated with exposure to fine particulate matter (Xia et al. 2006). Oxidative stress is a cellular condition that occurs when a cell's capacity to neutralize ROS is exceeded and may result in oxidative damage to membranes, DNA and other cell constituents. The potential of NPs of different sizes to induce ROS in RAW 264.7 macrophages was determined by means of the widely used $\mathrm{H}_{2}$ DCF-DA probe, which upon oxidation converts to a fluorescent dye.

Inhalation of particulate matter has been reported to result in the induction of a variety of inflammation markers such as cytokines and chemokines (Xia et al. 2009). Presumably, the function of these markers is to attract more phagocytic cells to clear the particles from the lungs. We investigated whether NPs of different sizes also induced markers of inflammation in peritoneal RAW 264.7 macrophages.

We further investigated the particle size related genotoxic potential of NPs by performing two genotoxicity assays which are commonly used in regulatory frameworks to measure chromosomal aberrations and gene mutations; both irreversible genotoxic endpoints. The micronucleus assay detects chromosomal aberrations and was performed in 3T3-L1 mouse fibroblasts, while gene mutations were measured in mouse embryonic fibroblasts isolated from pU288 plasmid lacZ mice, containing lacZ as a reporter gene (MEF-lacZ).

NPs have been shown to cross biological barriers such as the blood-brain barrier, bloodtestis barrier, the lung epithelial barrier and the placenta (Kreyling et al. 2002; Kwon et al. 2008; Semmler-Behnke et al. 2008; Yamashita et al. 2011). The latter findings indicate that NPs may become available to the developing embryo and warrant an investigation into the potential of NPs to induce developmental toxicity. We have therefore investigated the NPs in the embryonic stem cell test, which is regarded as a promising alternative in 
vitro method to in vivo developmental toxicity studies (Genschow et al. 2004). The test investigates the potential of compounds to inhibit differentiation of embryonic stem cells (D3 cells) into spontaneously contracting cardiomyocytes.

\subsubsection{Amorphous silica nanoparticles}

The compound $\mathrm{SiO}_{2}$ and the valuable uses of its amorphous form in for example glass and cement have been known since the distant past. With the rise of nanotechnology, amorphous $\mathrm{SiO}_{2} \mathrm{NPs}$ have gained the interest from a wide variety of industries. They are considered to be safe as additives in food, for agricultural and domestic use as pesticides and they are in the top five of ENMs explicitly referenced in a worldwide database of nanotechnology based consumer products (Barik et al. 2008; Hansen et al. 2008; Woodrow Wilson International Center for Scholars 2010). Their inert nature and small size make $\mathrm{SiO}_{2}$ NPs particularly interesting to the pharmaceutical industry, where they are in development for applications such as drug carriers, bio-imaging agents and gene transfection vectors (Slowing et al. 2008; Trewyn et al. 2007). Many of these promising applications can be anticipated to result in systemic bioavailability of $\mathrm{SiO}_{2} \mathrm{NPs}$, making these NPs relevant study objects for the in vitro studies used to explore the possibilities of extrapolating safety data from one NP to another.

The importance of ENM characterization prior to the investigation of their size related biological responses was emphasized when the primary particle size of the $\mathrm{SiO}_{2} \mathrm{NPs}$ were determined. The nominal sizes of the NPs reported by the manufacturer were 10, 30, 80 and $400 \mathrm{~nm}$, but TEM characterization revealed that the actual primary sizes were 11, 34, 34 and $248 \mathrm{~nm}$, respectively. As a consequence, only three rather than four different NP sizes could be investigated in the in vitro studies. Since the two $34 \mathrm{~nm}$ NPs had different surface potentials, both NPs were included in the studies and designated 34A and 34B. An overview of the results of the various assays with the $\mathrm{SiO}_{2} \mathrm{NPs}$ is presented in Table 8.1.

In Chapter 3, we investigated the size related potential of these NPs to inhibit stem cell differentiation in the embryonic stem cell test. A concentration dependent inhibition of differentiation of stem cells into contracting cardiomyocytes was observed for only two of the four $\mathrm{SiO}_{2} \mathrm{NPs}$, indicating that not all $\mathrm{SiO}_{2} \mathrm{NPs}$ induce the same response in this assay despite their similar chemical composition. However, the differences in the response could not be related to primary particle size alone: while NP 34A was the most potent of these NPs in inhibiting stem cell differentiation, NP $34 \mathrm{~B}$ had no effect at all up to the highest concentration tested, despite their virtually equal primary particle sizes. In addition to the 34A NPs, the $11 \mathrm{~nm}$ NPs also inhibited stem cell differentiation, while the $248 \mathrm{~nm}$ NPs had no effect. We investigated whether hydrodynamic sizes of NPs in cell culture medium may better explain the differences between the NPs, as these size measures include information on the aggregation status of the NPs, but these data are very difficult to interpret due to the dynamic nature of NP dispersions and the overlapping sizes of NPs and (clusters of) cell culture medium proteins. Qualitative TEM studies revealed $248 \mathrm{~nm}$ NPs in vacuoles of 
embryoid body cells, indicating that the lack of effects of particles of this diameter were not due to a lack of uptake.

\begin{tabular}{llllll} 
Particle & EST & Genotoxicity & Cell viabililty & ROS & $\begin{array}{l}\text { Inflammation } \\
\text { Markers }\end{array}$ \\
\hline $11 \mathrm{~nm}$ & + & - & & & ++ \\
$34 \mathrm{~nm} \mathrm{~A}$ & + & + & ++ & + & ++ \\
$34 \mathrm{~nm} \mathrm{~B}$ & - & ++ & ++ & ++ & + \\
$248 \mathrm{~nm}$ & - & - & + & + & + \\
\hline
\end{tabular}

EST: Embryonic Stem Cell Test; ROS: Reactive Oxygen Species

Table 8.1 Overview of the biological responses to silica nanoparticles of different sizes in various in vitro test systems.

In Chapter 4, we investigated the size related genotoxic potential of the $\mathrm{SiO}_{2} \mathrm{NPs}$ in the in vitro micronucleus assay and the MEF-LacZ gene mutation assay. Again, different effects of the two $34 \mathrm{~nm}$ NPs were observed, as only 34B NPs induced the formation of micronuclei in 3T3-L1 mouse fibroblasts. All other NPs, including 34A, did not affect the formation of micronuclei, despite TEM studies demonstrating that all NPs were taken up in the cells. In contrast to the micronucleus results, both $34 \mathrm{~nm}$ NPs increased the mutant frequencies in the MEF-LacZ gene mutation assay, while the 11 and $248 \mathrm{~nm}$ NPs did not. The results of these studies already indicate that the responses to $\mathrm{SiO}_{2} \mathrm{NPs}$ cannot be predicted based on primary particle size alone, similar to the findings of Chapter $\mathbf{3}$.

Further evidence for this is presented in Chapter 5, where we investigated size related effects of $\mathrm{SiO}_{2} \mathrm{NPs}$ on cell viability, induction of ROS and markers of inflammation. While all NPs had similar effects on cell viability and induction of ROS (with both $34 \mathrm{~nm}$ NPs being most potent), markers of inflammation were mainly induced by $11 \mathrm{~nm} \mathrm{NPs}$ and one of the $34 \mathrm{~nm} \mathrm{NPs}, 34 \mathrm{~A}$. An interesting fact in this respect is that the markers of inflammation were determined in the same experiments as those for metabolic activity; hence, the exact same NP dispersions and testing conditions (cell type, cell culture medium, and incubation time) were used. This excludes the possibility that differences in the role of NP size between these different assays were somehow caused by differences in experimental set-ups.

\subsubsection{Silver nanoparticles}

Ag NPs are currently the number one ENMs in the worldwide database ranking materials referenced in nanotechnology based consumer products (Hansen et al. 2008; Woodrow Wilson International Center for Scholars 2010). The reason for the increasing prevalence of Ag NPs in consumer products is their effective antibacterial properties, which also render them of great interest to the food production and the medical industry. Various applications of Ag NPs may lead to systemic exposure, although it is unknown if and to 
what extent the Ag NPs will dissolve into ions before reaching the systemic circulation (Wijnhoven et al. 2009).

In our studies described in Chapter 6, we have investigated the role of Ag NP size in the same assays used for $\mathrm{SiO}_{2}$ NPs, using Ag NPs of $20 \mathrm{~nm}, 80 \mathrm{~nm}$ and $113 \mathrm{~nm}$ (Table 8.2). Metabolic activity and membrane integrity was investigated in RAW 264.7 macrophages and L929 fibroblasts, and effects of Ag NPs were compared to those of silver in ionic form. We also investigated the role of Ag NP size in the generation of ROS and induction of parameters of inflammation in RAW 264.7 macrophages. Lastly, the role of Ag NP size was investigated in the EST and in the LacZ genotoxicity test in mouse embryonic fibroblasts.

\begin{tabular}{llllll} 
Particle & EST & Genotoxicity & Cell viability & ROS & $\begin{array}{l}\text { Inflammation } \\
\text { Markers }\end{array}$ \\
\hline $20 \mathrm{~nm}$ & ++ & - & ++ & ++ & ++ \\
$80 \mathrm{~nm}$ & + & - & + & + & + \\
$113 \mathrm{~nm}$ & + & - & - & - & + \\
\hline
\end{tabular}

EST: Embryonic Stem Cell Test; ROS: Reactive Oxygen Species

Table 8.2 Overview of the biological responses to silver nanoparticles of different sizes in various in vitro test systems.

Compared to the larger nanoparticles, the $20 \mathrm{~nm}$ Ag NPs induced the highest response in all assays included in our studies, in some assays with differences between $\mathrm{EC}_{20}$ values up to one order of magnitude. Possibly, smaller Ag NPs may release more Ag ions from the surface than larger NPs. If, upon contact with biological systems, Ag NPs immediately dissolve into Ag ions, an extra NP related health risk from Ag NPs is unlikely. However, the response of $L 929$ fibroblasts to $20 \mathrm{~nm} \mathrm{Ag} \mathrm{NPs} \mathrm{was} \mathrm{higher} \mathrm{than} \mathrm{to} \mathrm{an} \mathrm{equal} \mathrm{mass}$ concentration of $\mathrm{Ag}$ ions, indicating a specific particle related effect in this cell type. In contrast, in RAW 264.7 macrophages and D3 embryonic stem cells, Ag NPs of all sizes were equally or less toxic than Ag ions. The observation that the highest exposed cell types, macrophages, were not the most sensitive to the effects of Ag NPs indicates that other cell types need to be included in the evaluation of the biocompatibility of ENMs.

\subsubsection{Extrapolation of safety data}

The results from Chapter 3, 4 and 5 collectively indicate that safety data from $\mathrm{SiO}_{2} \mathrm{NPs}$ of one size cannot readily be extrapolated to $\mathrm{SiO}_{2} \mathrm{NPs}$ of other sizes. Clearly, NP characteristics other than primary particle size play an (additional) role in the responses to these particles. At first glance, this is in contrast to what others have reported. In studies by both Waters et al. (2009) and Napierska et al. (2009), cellular response to $\mathrm{SiO}_{2} \mathrm{NPs}$ consistently increased with decreasing NP diameter. A few differences between these studies and ours may explain these conflicting results. First of all, both studies mentioned above omitted serum 
during NP exposure of the cells. In addition, in contrast to our $\mathrm{SiO}_{2}$ NPs, those studied by Waters et al. (2009) and Napierska et al. (2009) were all quite well dispersed and may all have had similar surface potentials, for which information was lacking. Possibly, NP surface potential is an important characteristic, but a systematic investigation using $\mathrm{SiO}_{2}$ NPs with different surface potentials is required to confirm this.

Another important outcome of our studies with $\mathrm{SiO}_{2} \mathrm{NPs}$ is that the NP characteristics affecting one type of response are different from those affecting another response. A consequence is that comparative hazard analysis of ENMs always needs to include assays for various biological responses.

The results of our studies with Ag NPs indicated that the biological response to Ag NPs increases with decreasing particle size, possibly linked to the release of toxic $\mathrm{Ag}$ ions from the surface. Based on this, one could suggest that one exposure limit derived for a small $\mathrm{Ag} \mathrm{NP}$, e.g. $10 \mathrm{~nm}$, may be sufficient for extrapolation to larger Ag NPs. However, apart from the limited number of NP sizes included in our studies, we have only investigated uncoated Ag NPs with similar surface potentials. In addition to NP size, their surface potential and chemistry may play an additional and even larger role in the induced biological responses.

Even if these properties do not play any role of importance, deriving a single exposure limit that applies to NPs of all sizes is still not an ideal situation. For example, manufacturers that wish to improve the safety of their product by using larger Ag NPs may become restricted to unrealistic exposure limits derived on the basis of responses induced by much smaller Ag NPs.

A more sophisticated way to extrapolate between exposure limits for different Ag NPs would be to derive an exposure limit based on safety data of a well defined NP and adjusting this limit up for larger NPs or down for smaller NPs. This approach raises the question by how much such exposure limits should be adjusted. Should it be in proportion with the diameter, or perhaps surface area, or volume of the NP? In order to derive appropriate exposure limits for ENMs, it may help to define the relation between NP properties and the dose required to induce their response. This relation can then be integrated in the dose metric of NPs, in such a way that a single exposure limit can be derived that is applicable for groups of NPs. The focus of the last objective of this thesis was an investigation of appropriate dose metrics for $\mathrm{SiO}_{2}$ and Ag NPs.

\subsection{APPROPRIATE DOSE METRICS FOR SILICA AND SILVER NANOPARTICLES}

In Chapter 7, we presented a method to systematically investigate what might be an appropriate dose metric for ENMs. This method is based on identifying equal responses in test systems to a range of ENMs that vary in a particular property, and determining how the doses that lead to these equal responses depend on the varied property. The method 
was applied to data presented in Chapter $\mathbf{5}$ and $\mathbf{6}$ from various in vitro assays with a range of $\mathrm{SiO}_{2}$ and $\mathrm{Ag}$ NPs that varied in particle diameter.

One of the main outcomes of these studies was that this method helped to determine the relation between NP size and the dose required to induce a specified response in various assays. For example, the metabolic activity of RAW 264.7 macrophages by $\mathrm{SiO}_{2}$ NPs was decreased proportionally to its administered mass, while the induction of ROS in these macrophages by Ag NPs was increased proportionally to its administered surface area. The inhibition of stem cell differentiation was also related to the diameter of $\mathrm{Ag}$ NPs, but was not proportional to either its surface area or its volume. Such quantifiable relations can be helpful in deriving dose metrics for exposure limits and safety studies.

Our studies indicated that it was not possible to use the same dose metric for all ENMs consisting of different chemical compositions. Nevertheless, the ability to derive a single dose metric for ENMs of the same chemical composition but with different diameters still has the advantage that it can be extrapolated to ENMs consisting of NPs with different size distributions. In addition, further systematic research into appropriate dose metrics of a wide variety of ENMs may help to group ENMs of different chemical compositions for which similar dose metrics can be used.

Another outcome of these studies was that the appropriate dose metric for ENMs was not just dependent on the chemical composition of the ENMs, but also on the biological response considered. Naturally, this situation is far from ideal for risk assessment and regulatory purposes, since it suggests that multiple exposure limits would have to be derived for the same ENM. In the illustrative example of solid, spherical Ag NPs given in Chapter 7, one would have to derive an exposure limit based on metabolic activity and induction of ROS using total surface area S as the dose metric, and another exposure limit based on embryonic stem cell differentiation using $N x d^{2.4}$ as a dose metric (where $N$ $=$ number of particles and $d=$ NP diameter). Subsequently, these exposure limits would have to be compared to information on the size distribution and biodistribution of the specific ENM under consideration to determine which limit is to be used. Obviously, this will become a very laborious exercise if it turns out that the appropriate dose metric for every single response measured in safety studies is different, and may even be affected by different exposure routes. A systematic investigation of dose metrics with in vivo data in a similar way as presented for the in vitro data in Chapter 7 may help to determine whether deriving multiple exposure limits for one ENM is a rational approach, or whether multiple biological responses can be described with the same dose metric.

\subsection{CONCLUSIONS}

A number of factors have been identified that affect the outcome of in vitro studies with ENMs, many of which can be controlled relatively easily. In order to make these in vitro 
assays useful for comparative hazard analysis of ENMs, the experimental conditions need to be fine-tuned to better represent in vivo exposure to ENMs, which inevitably requires more comparative in vitro and in vivo data. Specifically, it is anticipated that submerged cell culture models using FCS are more relevant for systemic exposure to ENMs than for inhalation exposure, for which air-liquid exposure systems may be more appropriate.

Using controlled submerged cell culture models for systemically relevant biological responses, we demonstrated that the effects of Ag NPs increased with decreasing particle diameter, which may be related to an increased release of Ag ions from the relatively larger surface area of smaller NPs. While these results confirm the notion that smaller particles are more biologically active than larger ones, we have also demonstrated that for $\mathrm{SiO}_{2} \mathrm{NPs}$, particle diameter is not the only NP property affecting the biological response in various in vitro assays. This indicates that safety data of ENMs cannot readily be extrapolated across particles with different diameters until the roles of other NP properties in various biological responses are better understood.

A helpful tool for understanding these roles is the graphical method we introduced to investigate the relation between NP properties and the dose required to induce specified biological responses. This relation can subsequently be used to derive an appropriate dose metric for ENMs. Applying this method to data from various in vitro assays with $\mathrm{Ag}$ and $\mathrm{SiO}_{2}$ NPs revealed that appropriate dose metrics differed with the chemical composition of the NPs, but also with the biological responses considered. More systematic research using this graphical method may help to group ENMs and biological responses for which similar dose metrics can be used.

All in all, ENMs prove to remain a challenge for risk assessors and regulators, but further development of the approaches described in this thesis will help to elucidate patterns that will distinguish between more and less hazardous ENMs. 


\section{REFERENCES}

Barik TK, Sahu B, Swain V. 2008. Nanosilica-from medicine to pest control. Parasitol Res 103(2):253-8.

Clift MJ, Bhattacharjee S, Brown DM, Stone V. 2010. The effects of serum on the toxicity of manufactured nanoparticles. Toxicol Lett 198(3):358-65.

Clift MJ, Gehr P, Rothen-Rutishauser B. 2011. Nanotoxicology: a perspective and discussion of whether or not in vitro testing is a valid alternative. Arch Toxicol 85(7):723-31.

De Jong WH, Hagens WI, Krystek P, Burger MC, Sips AJ, Geertsma RE. 2008. Particle size-dependent organ distribution of gold nanoparticles after intravenous administration. Biomaterials 29(12):1912-9.

Genschow E, Seiler A, Spielman H. 2004. Considering the test performance of three class data using linear discriminant analysis. Altern Lab Anim 32:713-23.

Hansen SF, Michelson ES, Kamper A, Borling P, Stuer-Lauridsen F, Baun A. 2008. Categorization framework to aid exposure assessment of nanomaterials in consumer products. Ecotoxicology 17(5):438-47.

Klein SG, Hennen J, Serchi T, Blomeke B, Gutleb AC. 2011. Potential of coculture in vitro models to study inflammatory and sensitizing effects of particles on the lung. Toxicol In Vitro 25(8):151634.

Kreyling WG, Semmler M, Erbe F, Mayer P, Takenaka S, Schulz H, Oberdorster G, Ziesenis A. 2002. Translocation of ultrafine insoluble iridium particles from lung epithelium to extrapulmonary organs is size dependent but very low. J Toxicol Environ Health A 65(20):1513-30.

Kwon JT, Hwang SK, Jin H, Kim DS, Minai-Tehrani A, Yoon HJ, Choi M, Yoon TJ, Han DY, Kang YW et al. 2008. Body distribution of inhaled fluorescent magnetic nanoparticles in the mice. J Occup Health 50(1):1-6.

Lankveld DP, Oomen AG, Krystek P, Neigh A, Troost-de Jong A, Noorlander CW, Van Eijkeren JC, Geertsma RE, De Jong WH. 2010. The kinetics of the tissue distribution of silver nanoparticles of different sizes. Biomaterials 31(32):8350-8361.

Lipka J, Semmler-Behnke M, Sperling RA, Wenk A, Takenaka S, Schleh C, Kissel T, Parak WJ, Kreyling WG. 2010. Biodistribution of PEG-modified gold nanoparticles following intratracheal instillation and intravenous injection. Biomaterials 31(25):6574-81.

Lundqvist M, Stigler J, Elia G, Lynch I, Cedervall T, Dawson KA. 2008. Nanoparticle size and surface properties determine the protein corona with possible implications for biological impacts. Proc Natl Acad Sci U S A 105(38):14265-70.

Lynch I, Salvati A, Dawson KA. 2009. Protein-nanoparticle interactions: What does the cell see? Nat Nanotechnol 4(9):546-7.

Murdock RC, Braydich-Stolle L, Schrand AM, Schlager JJ, Hussain SM. 2008. Characterization of nanomaterial dispersion in solution prior to in vitro exposure using dynamic light scattering technique. Toxicol Sci 101(2):239-253.

Napierska D, Thomassen LC, Rabolli V, Lison D, Gonzalez L, Kirsch-Volders M, Martens JA, Hoet PH. 2009. Size-dependent cytotoxicity of monodisperse silica nanoparticles in human endothelial cells. Small 5(7):846-53.

Oberdorster G, Maynard A, Donaldson K, Castranova V, Fitzpatrick J, Ausman K, Carter J, Karn B, Kreyling W, Lai $D$ et al. 2005. Principles for characterizing the potential human health effects from exposure to nanomaterials: elements of a screening strategy. Part Fibre Toxicol 2:8. 
Sadauskas E, Wallin H, Stoltenberg M, Vogel U, Doering P, Larsen A, Danscher G. 2007. Kupffer cells are central in the removal of nanoparticles from the organism. Part Fibre Toxicol 4:10.

Semmler-Behnke M, Kreyling WG, Lipka J, Fertsch S, Wenk A, Takenaka S, Schmid G, Brandau W. 2008. Biodistribution of 1.4- and 18-nm gold particles in rats. Small 4(12):2108-11.

Slowing, II, Vivero-Escoto JL, Wu CW, Lin VS. 2008. Mesoporous silica nanoparticles as controlled release drug delivery and gene transfection carriers. Adv Drug Deliv Rev 60(11):1278-88.

Trewyn BG, Giri S, Slowing, II, Lin VS. 2007. Mesoporous silica nanoparticle based controlled release, drug delivery, and biosensor systems. Chem Commun (Camb)(31):3236-45.

Warheit DB. 2008. How meaningful are the results of nanotoxicity studies in the absence of adequate material characterization. Toxicol Sci 101(2):183-185.

Waters KM, Masiello LM, Zangar RC, Tarasevich BJ, Karin NJ, Quesenberry RD, Bandyopadhyay S, Teeguarden JG, Pounds JG, Thrall BD. 2009. Macrophage responses to silica nanoparticles are highly conserved across particle sizes. Toxicol Sci 107(2):553-69.

Wijnhoven SWP, Peijnenburg WJGM, Herberts CA, Hagens WI, Oomen AG, Heugens EHW, Roszek B, Bisschops J, Gosens I, Van De Meent D et al. 2009. Nano-silver - a review of available data and knowledge gaps in human and environmental risk assessment. Nanotoxicology 3(2):109-138.

Woodrow Wilson International Center for Scholars 2010. An inventory of nanotechnology-based consumer products currently on the market [internet]. 2006 March - [cited 2009 October]. Available from: http://www.nanotechproject.org/inventories/consumer/

Xia T, Kovochich M, Brant J, Hotze M, Sempf J, Oberley T, Sioutas C, Yeh JI, Wiesner MR, Nel AE. 2006. Comparison of the abilities of ambient and manufactured nanoparticles to induce cellular toxicity according to an oxidative stress paradigm. Nano Lett 6(8):1794-807.

Xia T, Li N, Nel AE. 2009. Potential health impact of nanoparticles. Annu Rev Public Health 30:13750.

Yamashita K, Yoshioka Y, Higashisaka K, Mimura K, Morishita Y, Nozaki M, Yoshida T, Ogura T, Nabeshi $H$, Nagano $K$ et al. 2011. Silica and titanium dioxide nanoparticles cause pregnancy complications in mice. Nat Nanotechnol 6(5):321-8. 




\section{NEDERLANDSE SAMENVATTING}

\section{INLEIDING}

Nanotechnologie is een nieuwe manier van materialen maken. Met behulp van nanotechnologie kunnen vaste stoffen heel gericht en op zeer kleine schaal, namelijk $1 \times 10^{-9}$ meter, voorzien worden van allerlei gewenste nieuwe eigenschappen: bolletjes, cilinders, driehoekjes, kristallen variërend in grootte en bestaande uit iedere gewenste chemische samenstelling, met bijvoorbeeld een betere geleiding, groter oppervlak, of andere kleur dan het uitgangsmateriaal.

De toepassingen van nanotechnologie zijn eindeloos. Coatings van nanokoolstofbuisjes worden aangebracht op tennisrackets om ze steviger te maken, of op bureaubladen om deze krasvast te maken. Titanium dioxide wordt al tijden toegevoegd aan zonnebrandcrème als UV filter, maar in nanovorm word het materiaal efficiënter en bovendien kleurloos in plaats van wit. Ook voor de geneesmiddelenindustrie is nanotechnologie uitermate interessant. Zo maakt men bijvoorbeeld nanobolletjes van zilver, die met hun antibacteriële werking aangebracht worden op verband voor brandwonden om zo ontstekingen te voorkomen. Medicijnen die in hun originele vorm moeilijk op de gewenste plek terechtkomen, kunnen verpakt worden in kleine silicabolletjes die wél bepaalde biologische barrières kunnen passeren. Om na te gaan of deze bolletjes daadwerkelijk bij het doelorgaan terechtgekomen zijn, kunnen de bolletjes bovendien voorzien worden van een label dat in het lichaam gevolgd kan worden, of van antilichamen die specifiek binden aan cellen van het doelorgaan.

Veel toepassingen zijn nog in ontwikkeling, maar er verschijnen steeds meer producten op de markt die gemaakt zijn met behulp van nanotechnologie, waaronder alledaagse gebruiksproducten voor consumenten zoals tandpasta, anti-zweetsokken en de reeds genoemde zonnebrandcrème. Mensen worden dus al dagelijks aan dit soort materialen blootgesteld en de verwachting is dat dit de komende tijd sterk zal toenemen.

Met de populariteit van nanotechnologie groeit ook de bezorgdheid over de veiligheid van deze veelbelovende nanomaterialen voor de volksgezondheid. Nanodeeltjes zouden bijvoorbeeld mogelijk DNA-schade aan kunnen richten. Voor 'gewone' stoffen geldt dat de risico's voor mens en milieu grondig in kaart moeten worden gebracht voordat men ze op de markt mag brengen. Een onderdeel van dit risicobeoordelingsproces is vaak het testen van de stof in verschillende dierproeven. Op basis hiervan wordt een veilig blootstellingsniveau afgeleid. In principe gelden dezelfde regels voor nanomaterialen, maar het is onduidelijk wanneer een 'nieuw' nanomateriaal getest moet worden. Nanomaterialen bestaan vrijwel altijd uit chemische samenstellingen die als 'gewone' stof veilig zijn bevonden en vaak al lange tijd worden toegepast. Een voorbeeld: zilver wordt al eeuwen gebruikt in sieraden zonder dat hier nadelige gevolgen van bekend zijn. Zouden nanobolletjes 
van ditzelfde metaal dan wél een risico vormen? Dat zou kunnen! Het nanomateriaal zilver heeft namelijk andere eigenschappen dan het metaal zilver, zoals een hogere antibacteriële activiteit. Bovendien kunnen de zilverbolletjes die in een verband op een open wond worden aangebracht door hun kleine afmetingen op eerder ontoegankelijke plekken in het menselijk lichaam terechtkomen. Men zou ervoor kunnen pleiten dat alle nanomaterialen een nieuw risicobeoordelingsproces moeten ondergaan voordat ze op de markt gebracht mogen worden. De variatiemogelijkheden voor nanomaterialen zijn echter gigantisch. Een nieuw risicobeoordelingsproces voor ieder nieuw materiaal zou een groot aantal proefdieren en geld kosten. Ook zou dat de veelbelovende mogelijkheden van deze technologie belemmeren. Er zijn dus dringend snellere en efficiëntere manieren nodig om de mogelijke risico's van nanomaterialen in kaart te brengen.

In dit proefschrift hebben we drie methoden onderzocht die de risicobeoordeling van nanomaterialen efficiënter zouden kunnen maken:

1) De mogelijkheid om in vitro testen (testen met cellen afkomstig van proefdieren of mensen) te gebruiken om onderscheid te maken tussen meer en minder toxische nanomaterialen.

2) De mogelijkheid om veiligheidsgegevens van één nanomateriaal te gebruiken voor een ander nanomateriaal met dezelfde chemische samenstelling maar van andere afmeting.

3) Het vinden van een geschikte maat (massa, oppervlakte, aantal deeltjes) om een dosis nanomaterialen in uit te drukken, waaruit bijvoorbeeld één blootstellinglimiet voor meerdere, verschillende nanomaterialen afgeleid kan worden.

\section{IN VITRO TESTEN VOOR DE RISICOBEOORDELING VAN NANOMATERIALEN}

In vitro testen worden vaak genoemd als mogelijkheid om voor de risicobeoordeling alvast een onderscheid te maken tussen meer en minder toxische nanomaterialen. Deze testen maken gebruik van cellen (vaak afkomstig van rat, muis of mens) die in het laboratorium gekweekt kunnen worden en waarmee een bepaalde biologische respons (bijvoorbeeld de vorming van ontstekingsmarkers, of celdood) gemeten kan worden. In hoofdstuk 2 hebben we op basis van een systematische vergelijking van gepubliceerde in vitro studies met nanomaterialen bekeken of deze testen mogelijk geschikt zijn een rol te spelen in de risicobeoordeling van nanomaterialen.

Een belangrijk onderwerp dat uit deze literatuuranalyse naar voren kwam, was dat de manier van blootstellen in in vitro test mogelijk niet representatief is voor de blootstelling die daadwerkelijk in mensen plaatsvindt. Dit geldt vooral voor in vitro testen die gebruikt worden om effecten van nanomaterialen in de long te onderzoeken. De meeste in vitro testen maken namelijk gebruik van cellen die gekweekt worden onder een laag celkweekmedium waaraan de te onderzoeken nanomaterialen toegevoegd 
worden. In de long vindt de blootstelling van cellen echter plaats via de lucht. Daarin gedragen deeltjes zich anders dan in vloeistof. Ze gaan bijvoorbeeld meer klonteren, waardoor de blootstelling anders wordt. Bovendien wordt bij in vitro testen vaak serum met eiwitten aan het celkweekmedium toegevoegd. Deze eiwitten gaan op het oppervlak van de nanodeeltjes plakken en kunnen hierdoor het klonteren van deeltjes beïnvloeden. Ook kunnen oppervlakte gerelateerde eigenschappen zoals reactiviteit van de deeltjes veranderen. Dit soort eiwitten is in de long echter niet aanwezig. Kortom, in vitro testsystemen waarbij cellen 'ondergedompeld' zijn in eiwitbevattend celkweekmedium zijn mogelijk niet geschikt om effecten op longcellen te onderzoeken. Daarom wordt door verschillende onderzoeksgroepen gewerkt aan de ontwikkeling van in vitro testsystemen waarin cellen via de lucht kunnen worden blootgesteld. Voor blootstellingen die leiden tot opname van nanomaterialen in de bloedsomloop, zijn ondergedompelde testsystemen waarschijnlijk relevanter, omdat cellen in rest van het lichaam ook in contact staan met eiwitbevattende vloeistof, in tegenstelling tot die in de long.

Toch blijkt het ook voor deze routes lastig om gegevens uit verschillende gepubliceerde studies met elkaar te vergelijken. Sommige nanomaterialen zijn niet goed te combineren met bepaalde types testen. Verder hebben de verschillende studies een uiteenlopende keuze in verschillende types testen, celtypes en blootstellingduur; dit beïnvloedt de uitkomst van experimenten. Bovendien kunnen concentraties waarbij effecten gezien worden in vitro niet zonder meer vertaald worden naar concentraties in vivo, waardoor er niet direct veilige blootstellinglimieten voor mensen uit afgeleid kunnen worden. Ook zijn er nog geen geaccepteerde in vitro testen beschikbaar om bijvoorbeeld effecten op de voortplanting en op het immuunsysteem te bestuderen. Een risicobeoordeling van nanomaterialen volledig baseren op in vitro studies is dus nog niet mogelijk. Het gebruik van in vitro testen is daarom vooralsnog vooral nuttig om de toxiciteit van deeltjes onderling te vergelijken, in het bijzonder voor effecten die relevant zijn voor deeltjes die opgenomen worden in het lichaam.

\section{VEILIGHEIDSGEGEVENS VAN ÉÉN NANOMATERIAAL GEBRUIKEN VOOR EEN NANOMATERIAAL MET ANDERE AFMETINGEN}

Een andere manier om het aantal testen met nanomaterialen terug te dringen, is het gebruiken van veiligheidsgegevens van één nanomateriaal voor de risicobeoordeling van andere nanomaterialen. Dit kan als er een verband wordt gevonden tussen een bepaalde eigenschap van het nanomateriaal en de effecten die het teweegbrengt. In hoofdstuk 3 tot en met $\mathbf{5}$ hebben we onderzocht of de effecten van nanodeeltjes van silica groter zijn naarmate de nanodeeltjes kleiner zijn. In hoofdstuk 6 hebben we hetzelfde gedaan voor nanodeeltjes van zilver. We hebben gebruik gemaakt van een aantal in vitro testen die relevant zijn voor in het lichaam opgenomen deeltjes, daarbij rekeninghoudend met de 
in hoofdstuk $\mathbf{2}$ genoemde factoren die de uitkomsten van dit soort testsystemen kunnen beïnvloeden.

\section{In vitro testsystemen}

Alle nanomaterialen die we hebben meegenomen in het onderzoek zijn uitgebreid beschreven. Voor ieder nanomateriaal zijn in ieder geval de morfologie, primaire en hydrodynamische grootte(distributie), concentratie, oppervlaklading en reactiviteit van de deeltjes bepaald. Ook hebben we vastgesteld dat de nanodeeltjes vrij waren van bacteriële besmettingen en mogelijk toxische productieresiduen. De biologische effecten van deze goed beschreven deeltjes hebben we vervolgens in een aantal verschillende in vitro testen bestudeerd.

Om algemene toxische effecten van deeltjes op cellen te bepalen, hebben we twee cytotoxiciteitstesten gebruikt. Met de WST-1 test kan bepaald worden of de metabolische activiteit van cellen daalt na blootstelling aan nanodeeltjes. Schade aan celmembranen is bepaald met behulp van de LDH test. Deze testen zijn uitgevoerd in minstens twee verschillende celtypes. Ten eerste hebben we voor een macrofaag gekozen, omdat deze celtypen een belangrijke rol in het lichaam spelen bij het opruimen van deeltjes. Als een meer algemeen celtype zijn ook fibroblasten meegenomen in het onderzoek.

Effecten van blootstelling aan fijn stof worden vaak geassocieerd met ontstekingen in de long waarbij radicalen en - al dan niet gerelateerd hieraan - ontstekingsmarkers zoals cytokines gevormd worden. In het huidige onderzoek hebben we de vorming van deze markers gemeten in macrofagen na blootstelling aan nanomaterialen.

De potentie van nanomaterialen om DNA-schade te veroorzaken hebben we bepaald met twee in vitro testen die ook vaak gebruikt worden voor de risicobeoordeling van 'gewone' stoffen: de micronucleus test en de genmutatie test.

Tenslotte hebben we de nanodeeltjes onderzocht in de embryonale stamceltest. Deze in vitro test wordt als een veelbelovend alternatief gezien voor dierproeven waarin de effecten van stoffen op de ontwikkeling van embryo's wordt beoordeeld. In de test worden muizenstamcellen blootgesteld aan nanomaterialen, waarna bekeken wordt of de cellen zich nog kunnen ontwikkelen tot kloppende hartspiercellen.

Op basis van deze testen is gekeken of de grootte van de deeltjes een rol speelde in de mate van de biologische effecten die ze induceerden.

\section{Resultaten met silica nanodeeltjes}

Silica is een verbinding die al sinds jaar en dag gebruikt wordt in glas en cement. Met de opkomst van nanotechnologie zijn de toepassingen van silica enorm uitgebreid. Silica nanodeeltjes worden toegepast als voedseladditief, bestrijdingsmiddel en staan in de top 5 van meest gebruikte nanomaterialen in consumentenproducten. Omdat silica zelf een ongevaarlijke stof is wekken nanodeeltjes van silica ook de belangstelling van de farmaceutische industrie, bijvoorbeeld als drager van geneesmiddelen. 
Vanvierverschillendesilicananodeeltjes(bolletjes)hebbenwederesponsin bovengenoemde testsystemen onderzocht: nanodeeltjes van gemiddeld $11 \mathrm{~nm}$ en $248 \mathrm{~nm}$ en twee nanodeeltjes van gemiddeld $34 \mathrm{~nm}$ ( $A$ en B) die onderling verschilden in oppervlaktelading.

In de embryonale stamceltest hadden twee van de vier nanodeeltjes een remmend effect op de ontwikkeling in kloppende hartspiercellen (hoofdstuk 3). Dit geeft aan dat van nanodeeltjes met dezelfde chemische samenstelling niet altijd dezelfde effecten verwacht kunnen worden. De verschillen konden echter niet toegeschreven worden aan de verschillende primaire groottes van de deeltjes. Van de twee $34 \mathrm{~nm}$ deeltjes remde slechts één (34A) de hartspier celdifferentiatie, terwijl de andere $34 \mathrm{~nm}$ deeltjes (34B) geen effect hadden. Ook de $248 \mathrm{~nm}$ deeltjes hadden geen effect, hoewel er met de electronenmicroscoop werd vastgesteld dat deze deeltjes wél werden opgenomen door de cellen.

Ook in de micronucleustest was er een verschil in effecten tussen de twee deeltjes van $34 \mathrm{~nm}$ (hoofdstuk 4). In deze test resulteerde alleen blootstelling aan het 34B deeltje in een verhoging van het aantal micronuclei. Alle andere deeltjes hadden geen effect, hoewel ze wel allemaal door de cellen werden opgenomen. In de andere genotoxiciteitstest, de LacZ genmutatietest veroorzaakten wél beide $34 \mathrm{~nm}$ deeltjes een verhoogde DNA-schade, terwijl de deeltjes van $11 \mathrm{~nm}$ en $248 \mathrm{~nm}$ dit niet deden. Blijkbaar worden de effecten in deze test bepaald door andere eigenschappen van de nanodeeltjes dan de effecten in de micronucleus test.

Dat verschillende deeltjeseigenschappen een rol spelen in verschillende testen wordt ook aangetoond in hoofdstuk 5, waar de effecten van de silica deeltjes zijn onderzocht in testen voor cytotoxiciteit en de vorming van radicalen en ontstekingsmarkers. Terwijl alle deeltjes bij vergelijkbare concentraties een effect hadden op cytotoxiciteit en de vorming van radicalen, werden ontstekingsmarkers voornamelijk gevormd na blootstelling aan de $11 \mathrm{~nm}$ en één van de $34 \mathrm{~nm}$ deeltjes (34A).

\section{Resultaten met zilver nanodeeltjes}

Zilver nanodeeltjes zijn momenteel de meest toegepaste nanomaterialen in consumentenproducten. Door hun sterk antibacteriële eigenschappen zijn ze zeer interessant voor de voedselproductie en de medische industrie. Veel van deze toepassingen kunnen leiden tot opname van zilverdeeltjes in het lichaam.

In hoofdstuk 6 hebben we de rol van deeltjesgrootte van zilver nanodeeltjes van drie verschillende groottes $(20 \mathrm{~nm}, 80 \mathrm{~nm}$ en $113 \mathrm{~nm}$ ) onderzocht in dezelfde testen als voor silica nanodeeltjes. In al deze testen hadden de $20 \mathrm{~nm}$ deeltjes meer effect dan de twee grotere deeltjes. Het is mogelijk dat er door het relatief grotere oppervlak van deze deeltjes meer zilverionen vrijkomen, en dat het de ionen zijn die de effecten veroorzaken. Echter, in L929 fibroblasten waren de $20 \mathrm{~nm}$ deeltjes cytotoxischer dan eenzelfde massa zilverionen. Dit duidt er op dat er een deeltjes specifiek effect plaatsvindt in dit celtype. In de andere celtypes (macrofagen en stamcellen) was de toxiciteit van de $20 \mathrm{~nm}$ deeltjes vergelijkbaar of minder dan zilverionen. 
De observatie dat de hoogst blootgestelde cellen, macrofagen, niet het meest gevoelig waren voor de zilverdeeltjes geeft aan dat meerdere celtypes meegenomen moeten worden in een in vitro evaluatie van de veiligheid van nanomaterialen.

\section{Het extrapoleren van veiligheidsgegevens}

De resultaten van in vitro testen met silicadeeltjes (hoofdstuk 3, 4 en 5) geven aan dat het niet zonder meer mogelijk is om veiligheidsgegevens van een silicadeeltje van één bepaalde grootte te gebruiken voor een silicadeeltje met een andere grootte. Blijkbaar spelen naast grootte ook andere eigenschappen een (aanvullende) rol in de effecten van deze deeltjes. Dit is op het eerste gezicht niet in samenspraak met wat andere onderzoekers hebben gevonden. In vergelijkbare cytotoxiciteitsstudies van zowel Waters et al. (2009) als Napierska et al. (2009) waren kleinere silicadeeltjes consequent toxischer dan grotere. Er zijn enkele mogelijke verklaringen voor deze verschillen. Ten eerste werd in bovengenoemde studies geen serum toegevoegd aan het celkweekmedium, wat de opname en de effecten van deeltjes beïnvloed kan hebben. Ten tweede is het mogelijk dat de deeltjes die in deze studies gebruikt zijn allemaal een vergelijkbare oppervlaklading hadden, terwijl dat in onze studie niet het geval was. Oppervlaklading speelt mogelijk een rol in de effecten van silica deeltjes, maar een systematisch onderzoek met silicadeeltjes met verschillende oppervlakteladingen is nodig om dit te bevestigen.

Uit onze studie is ook gebleken dat de eigenschappen die een rol spelen in de effecten van nanodeeltjes niet hetzelfde zijn voor alle testen. Dit betekent dat er altijd meerdere testen nodig zijn voor een veiligheidsevaluatie van nanomaterialen.

De resultaten van in vitro testen met zilverdeeltjes geven aan dat de effecten van zilverdeeltjes groter worden naarmate de deeltjes kleiner worden, mogelijk doordat er meer toxische zilverionen vrijkomen. Op basis hiervan zou men kunnen suggereren dat het mogelijk is om één blootstellinglimiet af te leiden voor alle zilverdeeltjes, gebaseerd op de veiligheidsgegevens van een klein zilverdeeltje. Hierbij moet echter opgemerkt worden dat de zilverdeeltjes in onze studie allemaal 'kaal' waren en dezelfde oppervlaklading hadden. Eigenschappen zoals oppervlaklading spelen mogelijk ook en misschien nog wel een grotere rol dan grootte in de effecten van nanodeeltjes.

Zelfs als deze eigenschappen geen enkele rol van betekenis zouden spelen, zou het afleiden van een enkele blootstellinglimiet voor alle zilverdeeltjes op basis van de gegevens van een klein zilverdeeltje nog geen ideale situatie zijn. Bijvoorbeeld, producenten die de veiligheid van hun product willen verbeteren door grotere zilverdeeltjes te gebruiken, kunnen zo beperkt worden door een onrealistische blootstellinglimiet die is afgeleid van gegevens over een veel kleiner zilverdeeltje. Het naar boven schroeven van deze blootstellinglimiet voor grotere zilverdeeltjes zou een geraffineerdere manier zijn. Maar met hoeveel moet deze blootstellinglimiet dan omhoog: evenredig met de diameter, het oppervlak, het volume? Of met een heel andere maat? Om dit te bepalen is het nodig om de relatie te definiëren tussen deeltjeseigenschappen en de dosis die nodig is om een 
effect te veroorzaken. Deze relatie kan vervolgens geïntegreerd worden in een dosismaat die gebruikt kan worden om een enkele blootstellinglimiet voor groepen deeltjes af te leiden.

\section{HET VINDEN VAN EEN JUISTE DOSISMAAT VOOR NANOMATERIALEN}

In hoofdstuk 7 presenteren we een methode waarmee systematisch kan worden onderzocht wat een juiste dosismaat zou kunnen zijn voor nanomaterialen. Deze methode is gebaseerd op het vinden van een relatie tussen deeltjeseigenschappen en de doses die leiden tot hetzelfde effect in een bepaald testsysteem. De methode werd toegepast op gegevens uit hoofdstuk 5 en 6 van verschillende in vitro testen met silica en zilver nanodeeltjes van verschillende groottes.

De methode bleek succesvol om een relatie te vinden tussen deeltjesgrootte en de dosis die nodig was om een effect te veroorzaken. Zo werd de metabole activiteit van macrofagen door silicadeeltjes verminderd in verhouding tot de toegediende massa, terwijl de vorming van radicalen in deze macrofagen door zilverdeeltjes evenredig verhoogd werd met het toegediende oppervlakte. De remming van stamceldifferentiatie was ook gerelateerd aan deeltjesgrootte van zilver, maar niet evenredig met de oppervlakte of het volume. Dergelijke kwantificeerbare relaties kunnen nuttig zijn bij de afleiding van de dosismaat voor blootstellinglimieten en voor doses in veiligheidsstudies.

Het bleek niet mogelijk om voor nanodeeltjes van verschillende chemische samenstellingen dezelfde dosismaat te gebruiken. Het gebruik van één dosismaat voor deeltjes met dezelfde chemische samenstelling heeft nog steeds als voordeel dat een enkele blootstellinglimiet kan worden afgeleid voor nanomaterialen met verschillende grootte(verdelingen).

Een ander resultaat van deze studie was dat de juiste dosismaat voor de nanodeeltjes niet alleen afhankelijk was van de chemische samenstelling van de deeltjes, maar ook van het type effect. Uiteraard is deze situatie verre van ideaal voor de risicobeoordeling en wettelijke doeleinden, omdat het suggereert dat meerdere blootstellinglimieten zou moeten worden afgeleid voor hetzelfde nanomateriaal. In het voorbeeld van de zilverdeeltjes zou men een blootstellinglimiet moeten afleiden voor metabole activiteit en inductie van radicalen met oppervlak als de dosismaat, en een andere blootstellinglimiet op basis van stamceldifferentiatie met $N x d^{2.4}$ als dosismaat (waarbij $N=$ aantal deeltjes en $d=$ NP diameter). Vervolgens zouden deze limieten moeten worden vergeleken met informatie over de grootteverdeling van het nanomateriaal in kwestie om te bepalen welke limiet moet worden gebruikt. Uiteraard is dit een zeer arbeidsintensief proces als blijkt dat de geschikte dosismaat voor elk type effect gemeten in veiligheidsstudies anders is, en zelfs kan worden beïnvloed door verschillende blootstellingsroutes. Systematisch onderzoek naar dosismaten met in vivo gegevens op een vergelijkbare manier zoals gepresenteerd 
voor de in vitro gegevens in hoofdstuk 7 kan helpen om te bepalen of afleiden van meerdere blootstellinglimieten voor één nanomateriaal een rationele benadering is, en of meerdere types effecten met dezelfde dosismaat kunnen worden beschreven.

\section{CONCLUSIES}

Er zijn verschillende factoren geïdentificeerd die de uitkomst van in vitro studies met nanomaterialen beïnvloeden, maar veel daarvan kunnen relatief eenvoudig onder controle worden gehouden. Om in vitro testen geschikt te maken voor een risicobeoordeling van nanomaterialen, moeten de experimentele omstandigheden zodanig worden afgestemd dat ze representatief zijn voor in vivo blootstelling aan nanomaterialen. Dit vereist onvermijdelijk het genereren van meer vergelijkende in vitro en in vivo gegevens. Concreet verwachten wij dat ondergedompelde celkweeksystemen waaraan serum is toegediend, relevanter zijn voor in het lichaam opgenomen nanomaterialen dan voor blootstelling van de longen, waarvoor lucht-vloeistof blootstellingsystemen wellicht geschikter zijn.

Met behulp van verschillende gecontroleerde in vitro testsystemen die relevant zijn voor in het lichaam opgenomen nanomaterialen, hebben we aangetoond dat de effecten van zilver nanodeeltjes toenamen naarmate de deeltjes kleiner waren. Dit houdt mogelijk verband met een verhoogde afgifte van zilverionen van het relatief grotere oppervlakte van kleinere nanodeeltjes. Hoewel deze resultaten het algemene idee bevestigen dat kleinere deeltjes biologisch actiever zijn dan grotere, hebben we ook aangetoond dat voor silica nanodeeltjes de grootte van de deeltjes niet de enige eigenschap is die de effecten van nanodeeltjes beïnvloedt. Dit geeft aan dat gegevens van nanomaterialen niet direct kunnen worden vertaald naar deeltjes met andere groottes. De rol van andere deeltjeseigenschappen in verschillende types effecten moet eerst beter worden begrepen.

Een handig hulpmiddel hierbij is de grafische methode die we hebben gepresenteerd om de relatie te onderzoeken tussen deeltjeseigenschappen en de dosis die nodig is om een bepaald effect te veroorzaken. Deze relatie kan vervolgens gebruikt worden om een geschikte dosismaat af te leiden voor nanomaterialen. Uit het toepassen van deze methode op gegevens van verschillende in vitro testen met zilver en silica nanodeeltjes bleek dat geschikte dosismaten afhankelijk waren van zowel de chemische samenstelling van de deeltjes als het type effect. Meer systematisch onderzoek met gebruik van deze grafische methode kan helpen om groepen nanomaterialen en effecten te identificeren waarvoor dezelfde dosismaten gebruikt kunnen worden.

Al met al blijft de risicobeoordeling van nanomaterialen een uitdaging, maar verdere ontwikkeling van de verschillende aanpakken die in dit proefschrift beschreven zijn, zal helpen om onderscheid te kunnen maken tussen meer en minder gevaarlijke nanomaterialen. 




\section{CURRICULUM VITAE}

Margriet van der Zee Park werd geboren in Leeuwarden op 19 februari 1976. Ze ging naar het VWO op de Rijksscholengemeenschap Magister Alvinus in Sneek, maar vertrok voor de laatste twee jaar van het VWO naar de United World College of the Atlantic in Llantwit Major, Wales, waar ze in 1994 het International Baccalaureate behaalde. In 1995 heeft Margriet als vrijwilliger gewerkt bij een ontwikkelingshulporganisatie in Kukwanisa, Zimbabwe. In 1996 is ze begonnen met de studie Biologie aan de Wageningen Universiteit, waar ze in 2001 afstudeerde. Tijdens haar studie heeft ze zich gespecialiseerd in toxicologie, waar ze de impact van milieucontaminanten bestudeerde, onder andere in een 'superfund site' langs de Kalamazoo rivier in Michigan. Deze stage leidde tot een onderzoeksplaats in het Aquatic Toxicology Lab van Michigan State University, waar ze onderzoek opgezet heeft naar de effecten van het bestrijdingsmiddel atrazine op de voortplanting van groene kikkers. Bij terugkomst naar Nederland werd zij als toxicoloog aangenomen door Lipid Nutrition BV, waar zij het toxicologie programma voor voedingssupplementen heeft opgezet. In 2004 is ze in dienst getreden bij het RIVM als beoordelaar blootstelling en humane toxicologie bij de afdeling Stoffen en Integrale Risicobeoordeling. In 2007 verhuisde ze naar het Laboratorium voor Gezondheidsbeschermingsonderzoek waar ze zich bezighoudt met onderzoek naar het bevorderen van de risicobeoordeling van nanomaterialen.

Margriet van der Zee Park was born on February 19th, 1976 in Leeuwarden, the Netherlands. She started VWO at the Rijksscholengemeenschap Magister Alvinus in Sneek, but left to the United World College of the Atlantic in Llantwit Major, Wales in 1992 where she obtained her International Baccalaureate in 1994. Shortly after returning to the Netherlands, she went to Kukwanisa, Zimbabwe to work as a volunteer for a development aid organization. In 1996 she started her Master's course in Biology at Wageningen University, and obtained her Master's Degree in 2001. During her studies, she specialized in toxicology where she investigated the impact of environmental contaminants, and participated in an environmental risk assessment at a superfund site along the Kalamazoo River in Michigan. This internship led to a place in the Aquatic Toxicology Laboratory of Michigan State University as a research assistant where she developed study proposals involving the herbicide atrazine and the reproductive success of green frogs. Upon her return to the Netherlands, she was recruited as the lead toxicologist at Lipid Nutrition BV where she developed its infant toxicology program for food supplement ingredients. She shifted her focus to government in 2004 by working for the RIVM as an Exposure assessor and Toxicologist in the Department of Substances and Integrated Risk Assessment, where she worked on topics such as risk factors in children's toys, consumer and scented products. In 2007, Margriet was hired to work at RIVM's Laboratory for Health Protection Research to conduct research aimed to further the risk assessment of nanomaterials. 



\section{LIST OF PUBLICATIONS}

Colognato R, Park MVDZ, Wick P, De Jong WH. 2011. Interactions with the Human Body. In: Fadeel B, Pietroiusti A, Shvedova AA, editors. Adverse Effects of Engineered Nanomaterials: Exposure, Toxicology and Impact on Human Health. Amsterdam: Elsevier.

Park MVDZ, Annema W, Salvati A, Lesniak A, Elsaesser A, Barnes C, McKerr G, Howard CV, Lynch I, Dawson KA et al. 2009a. In vitro developmental toxicity test detects inhibition of stem cell differentiation by silica nanoparticles. Toxicol Appl Pharmacol 240:108116.

Park MVDZ, Lankveld DPK, van Loveren H, de Jong W. 2009b. The status of in vitro toxicity studies in risk assessment of nanomaterials Nanomedicine 4(6):669-685.

Park MVDZ, Lynch I, Ramírez-García S, Dawson KA, de la Fonteyne L, Gremmer E, Briedé JJ, Slob W, Elsaesser A, Howard CV et al. 2011a. In vitro evaluation of cytotoxic and inflammation properties of silica nanoparticles of different sizes in murine RAW 264.7 macrophages. J Nanopart Res 13(12):6775-6787.

Park MVDZ, Neigh AM, Vermeulen JP, de la Fonteyne LJ, Verharen HW, Briede JJ, van Loveren $\mathrm{H}$, de Jong WH. 2011b. The effect of particle size on the cytotoxicity, inflammation, developmental toxicity and genotoxicity of silver nanoparticles. Biomaterials 32(36):9810-7.

Park MVDZ, Verharen HW, Zwart E, Hernandez LG, van Benthem J, Elsaesser A, Barnes C, McKerr G, Howard CV, Salvati A et al. 2011c. Genotoxicity evaluation of amorphous silica nanoparticles of different sizes using the micronucleus and the plasmid lacZ gene mutation assay. Nanotoxicology 5:168-81. 
